\title{
De arbeidsmarkt naar opleiding en beroep tot 2016
}

Citation for published version (APA):

Bertrand-Cloodt, D. A. M., Cörvers, F., Dohmen, T. J., Dupuy, A., Fouarge, D., de Grip, A., Kriechel, B., Nelen, A. C., \& van Thor, J. A. F. (2011). De arbeidsmarkt naar opleiding en beroep tot 2016. Researchcentrum voor Onderwijs en Arbeidsmarkt, Faculteit der Economische Wetenschappen. ROA Reports No. 8 https://doi.org/10.26481/umarep.2011008

Document status and date:

Published: 01/01/2011

DOI:

10.26481/umarep.2011008

Document Version:

Publisher's PDF, also known as Version of record

\section{Please check the document version of this publication:}

- A submitted manuscript is the version of the article upon submission and before peer-review. There can be important differences between the submitted version and the official published version of record.

People interested in the research are advised to contact the author for the final version of the publication, or visit the DOI to the publisher's website.

- The final author version and the galley proof are versions of the publication after peer review.

- The final published version features the final layout of the paper including the volume, issue and page numbers.

Link to publication

\footnotetext{
General rights rights.

- You may freely distribute the URL identifying the publication in the public portal. please follow below link for the End User Agreement:

www.umlib.nl/taverne-license

Take down policy

If you believe that this document breaches copyright please contact us at:

repository@maastrichtuniversity.nl

providing details and we will investigate your claim.
}

Copyright and moral rights for the publications made accessible in the public portal are retained by the authors and/or other copyright owners and it is a condition of accessing publications that users recognise and abide by the legal requirements associated with these

- Users may download and print one copy of any publication from the public portal for the purpose of private study or research.

- You may not further distribute the material or use it for any profit-making activity or commercial gain

If the publication is distributed under the terms of Article $25 \mathrm{fa}$ of the Dutch Copyright Act, indicated by the "Taverne" license above, 


\section{De arbeidsmarkt naar opleiding en beroep}

tot 2016

ROA-R-2011/8

Researchcentrum voor Onderwijs en Arbeidsmarkt

Maastricht University

School of Business and Economics

Maastricht, december 2OII 


\section{Colofon}

(C) Researchcentrum voor Onderwijs en Arbeidsmarkt (ROA). Niets uit deze uitgave mag op enige manier worden verveelvoudigd zonder voorafgaande schriftelijke toestemming van de directeur van het ROA. In geval van overname van het datamateriaal moet telkens als bron worden vermeld 'Researchcentrum voor Onderwijs en Arbeidsmarkt'of 'ROA'. Van publicaties waarin gebruik wordt gemaakt van gegevens uit dit rapport ontvangen wij gaarne een exemplaar.

Hoewel de grootst mogelijke zorg is besteed aan de inhoud van dit rapport, kan het ROA in generlei opzicht verantwoordelijkheid op zich nemen voor eventuele onvolledigheden of onjuistheden.

Dit rapport maakt deel uit van het Project Onderwijs-Arbeidsmarkt (POA). Dit project wordt gefinancierd door het Ministerie van Onderwijs, Cultuur en Wetenschap (OCW), het Uitvoeringsinstituut Werknemersverzekeringen (UWV), het UWV WERKbedrijf, het Ministerie van Economische Zaken, Landbouw en Innovatie (EL\&I), de samenwerkende kenniscentra voor beroepsonderwijs en bedrijfsleven COLO, Randstad Nederland en de Raad voor Werk en Inkomen (RWI).

\section{Researchcentrum voor Onderwijs en Arbeidsmarkt}

School of Business and Economics

Maastricht University

\section{Vormgeving}

ROA secretariaat, Maastricht

\section{Verkoop}

Researchcentrum voor Onderwijs en Arbeidsmarkt email: secretary-roa-sbe@maastrichtuniversity.nl website: www.roa.nl

ISBN: 978-90-532I-498-5

december $20 \mathrm{II}$ 


\section{Inhoud}

Ten geleide

Samenvatting

$\mathbf{v}$

Doel en opzet van de arbeidsmarktprognoses

ix

xvii

I De arbeidsmarkt in vogelvlucht I

I.I Inleiding I

I.2 Actuele situatie en verwachte ontwikkeling I

I.3 Werkgelegenheidsontwikkeling naar bedrijfssector II

I.4 Werkgelegenheidsontwikkeling naar beroepsklasse I2

I.5 Werkgelegenheidsontwikkeling naar opleidingsniveau I5

I.6 Toekomstige arbeidsmarktperspectieven naar opleidingsniveau I9

$\begin{array}{ll}\text { I.7 Conclusies } & 23\end{array}$

2 Ontwikkelingen op de arbeidsmarkt, 20II-20I6 25

2.I Inleiding 25

2.2 Uitbreidingsvraag 26

2.3 Vervangingsvraag 34

2.4 Baanopeningen 45

2.5 Arbeidsmarktinstroom 50

2.6 Conclusies $\quad 54$

$3 \quad$ Aansluiting tussen onderwijs en arbeidsmarkt 57

3.I Inleiding $\quad 57$

3.2 Huidige aansluitingsproblemen 58

3.3 Toekomstige arbeidsmarktperspectieven en knelpunten in de personeelsvoorziening naar opleiding 70

3.4 Beroepen, beloning en loonmobiliteit $\quad 76$

3.5 Toekomstige knelpunten in de personeelsvoorziening naar
beroep

3.6 Conclusies 83 
4 Het belang van deeltijdwerk: omvang, gevolgen en mogelijkheden van 'opplussen'

4.2 Ontwikkeling van deeltijdwerk

4.3 Gevolgen van deeltijdwerk voor werkenden 90

4.4 Gevolgen van deeltijdwerk voor bedrijven 95

4.5 'Opplussen' van deeltijdbanen 97

$\begin{array}{ll}4.6 \text { Conclusies } & \text { IO5 }\end{array}$

5 De rol van economische voorkeuren bij de beroepskeuze van schoolverlaters

5.I Inleiding

5.2 Relatie tot eerder onderzoek

5.3 Data en begrippen

5.4 Voorkeuren en beroepskenmerken

5.5 Vaardigheden en compenserende loonverschillen

5.6 Voorkeuren en mobiliteit

5.7 Conclusie

\section{Bijlage A}

Enkele centrale begrippen

\section{Bijlage B}

Classificaties naar sector, beroep en opleiding

\section{Bijlage C}

Verkrijgbare arbeidsmarktinformatie per bedrijfssector, beroepsgroep of opleidingstype 


\section{Ten geleide}

Het voorliggende rapport is de elfde uitgave van het Researchcentrum voor Onderwijs en Arbeidsmarkt (ROA) over de huidige en de toekomstige arbeidsmarktsituatie. Dit rapport verschijnt in een onzekere periode wat betreft de economische situatie en de arbeidsmarktontwikkelingen. In het voorliggende overzicht van de arbeidsmarktperspectieven naar opleiding en beroep wordt een beeld geschetst van de verwachte ontwikkelingen op de middellange termijn, rekening houdend met onder andere de vergrijzing en de instroom van jongeren op de arbeidsmarkt. Er is voor een tijdshorizon van circa vijf jaar gekozen om een zo goed mogelijk beeld te kunnen geven van de arbeidsmarktsituatie bij afstuderen van degenen die thans aan het begin van hun studie staan. Deze informatie is van belang voor zowel het geven van voorlichting aan degenen die aan een opleiding willen beginnen als voor werkgevers bij het nemen van strategische beslissingen over hun personeelsbeleid. Het rapport is in het bijzonder bedoeld voor de beleidsontwikkeling van de overheid, de arbeidsbemiddelingssorganisaties, de sociale partners en het onderwijsveld. Het rapport is gebaseerd op gedetailleerde arbeidsmarktinformatie naar sector, beroep en opleiding, zoals deze is opgenomen in het Arbeidsmarktinformatiesysteem (AIS) van het ROA.

Het rapport bestaat uit vijf hoofdstukken. De eerste drie hoofdstukken gaan over de actuele en verwachte ontwikkelingen op de arbeidsmarkt, gedifferentieerd naar sector, beroep en opleiding. Hoofdstuk I begint met een overzicht van de recente macro-economische ontwikkelingen in relatie tot de arbeidsmarkt, waarbij wordt ingegaan op het verband tussen werkloosheid en vacatures voor Nederland als geheel en de verschillende regio's. Vervolgens wordt een globaal overzicht gegeven van de verwachte arbeidsmarktontwikkelingen voor de periode 20II-20I6. In hoofdstuk 2 worden deze ontwikkelingen verder gedifferentieerd naar beroep en opleiding voor achtereenvolgens de uitbreidingsvraag, de vervangingsvraag, de baanopeningen en de arbeidsmarktinstroom. In hoofdstuk 3 staat de aansluiting tussen onderwijs en arbeidsmarkt centraal. In het hoofdstuk wordt eerst nader ingegaan op de actuele aansluitingsproblematiek op de arbeidsmarkt, waarna de toekomstige arbeidsmarktperspectieven van schoolverlaters besproken worden. $\mathrm{Na}$ een analyse van de beloning binnen beroepsgroepen wordt er ingegaan op de voor werkgevers te verwachten knelpunten in de personeelsvoorziening naar beroep.

De laatste twee hoofdstukken van het rapport behandelen elk een thema dat relevant is voor het beter functioneren van de arbeidsmarkt. In hoofdstuk 4 wordt uitgebreid 
ingegaan op het belang van deeltijdwerk op de arbeidsmarkt. Deeltijdwerkers kunnen van groot belang zijn voor de bedrijfsproductiviteit. Het op peil houden van hun kennis en vaardigheden verdient echter wel aandacht. In het hoofdstuk wordt aangegeven hoe het 'opplussen' van de arbeidsduur de tekorten op de arbeidsmarkt kan verminderen. In hoofdstuk 5 wordt onder meer gekeken naar de relatie tussen de beroepskeuze van jongeren en hun economische voorkeuren. Uit het hoofdstuk blijkt dat de beroepskeuze van jongeren verbeterd kan worden door meer informatie te geven over de beloning en het werkloosheidsrisico van beroepen.

In het rapport wordt slechts in beperkte mate ingegaan op de gehanteerde onderzoeksmethoden, de gehanteerde classificaties, enz. Hiervoor wordt verwezen naar de specifieke werkdocumenten en research memoranda van het ROA. Wel wordt er aan het begin van dit rapport ingegaan op de gebruiksdoelen van de prognoses en wordt een globaal overzicht gegeven van het gebruikte prognosemodel. Daarnaast worden in Bijlage A enkele kernbegrippen omschreven met verwijzingen naar de publicaties waarin nadere informatie is te vinden. In het binnenkort uit te brengen werkdocument Methodiek arbeidmarktprognoses en -indicatoren 20II-20I6 wordt een totaaloverzicht gegeven van het prognosemodel en de daarbij gebruikte methodiek. In Bijlage B wordt een overzicht gegeven van de gebruikte indelingen naar sector, beroep en opleiding. Tot slot wordt in Bijlage $\mathrm{C}$ ingegaan op de beschikbare informatie per bedrijfssector, beroepsgroep en opleidingstype.

Vermeldenswaardig is nog dat het ROA de voorspelkwaliteit van de prognoses evalueert na afloop van de prognoseperiode. Uit de evaluatie van de prognoses over de periodes 1999-2004 en 2003-2008 blijkt onder meer dat voor ruim 40\% van de ongeveer Ioo opleidingstypen de juiste van de vijf mogelijke typeringen werd gegeven. Voor ca. $80 \%$ van de opleidingstypen werd de juiste of een aangrenzende typering voorspeld. ${ }^{\mathrm{I}}$ De verschillende onderdelen van het prognosemodel van het ROA worden regelmatig geëvalueerd. ${ }^{2}$ De evaluatiestudies kunnen aanleiding geven om de prognosemodellen aan te passen of te vernieuwen. ${ }^{3}$

De projectleiding en eindredactie van De arbeidsmarkt naar opleiding en beroep tot 2016 is in handen van dr. F. Cörvers. Secretariële ondersteuning bij de totstandkoming van dit rapport is gegeven door M. Boere, W. Klein en E. Soudant. Hoofdstukken I, 2 en 3 zijn geschreven door dr. D. Bertrand-Cloodt, dr. F. Cörvers, dr. A. Dupuy,

I. A. Dupuy (2009), An evaluation of the forecast of the indicator of the labour market gap, ROA-TR2009/3, Universiteit Maastricht; D. Bertrand-Cloodt (2010), Evaluatie uitbreidingsvraag en indicator toekomstig arbeidsmarktperspectief (ITA) tot 2008, ROA-TR-20Io/6, Universiteit Maastricht. In de evaluatie van de prognoses tot 2002 waren deze percentages respectievelijk $64 \%$ en $93 \%$.

2. Zie bijv. voor de vervangingsvraag R. Montizaan (2009), Evaluatie vervangingsvraagprognoses naar opleiding en beroep, ROA-TR-2009/I, Universiteit Maastricht.

3. Een voorbeeld hiervan is het gebruik van paneldata uit de Enquête Beroepsbevolking (EBB) om de vervangingsvraag te schatten in plaats van het gebruik van standgegevens in de beproefde cohortcomponentenmethode. Zie F. Cörvers, S. Dijksman, B. Kriechel en R. Montizaan (20IO), Vervangingsvraag naar beroep en stromen op de arbeidsmarkt, ROA-TR-20Io/3, Universiteit Maastricht. 
dr. D. Fouarge en drs. J. van Thor. De analyses zijn uitgevoerd door dr. A. Dupuy en drs. J. Sauermann (uitbreidingsvraag en discrepantie-indicatoren), dr. D. BertrandCloodt (vervangingsvraag) en S. Dijksman BSc (arbeidsmarktinstroom). Tevens is dr. D. Fouarge nauw betrokken geweest bij het samenstellen van de prognoses. De analyse over deeltijdwerk in hoofdstuk 4 is uitgevoerd door drs. A. Nelen en prof. dr. A. de Grip. De analyse over de rol van economische voorkeuren bij de beroepskeuze in hoofdstuk 5 is uitgevoerd door prof. dr. T. Dohmen, dr. D. Fouarge en dr. B. Kriechel. Het bij dit rapport behorende geautomatiseerde Arbeidsmarktinformatiesysteem (AIS) is ontwikkeld door S. Dijksman BSc.

De rapportage vindt plaats in het kader van het door het ROA uitgevoerde Project Onderwijs-Arbeidsmarkt (POA). De start van dit project viel samen met de oprichting van het ROA 25 jaar geleden. Aan het Project Onderwijs-Arbeidsmarkt wordt financieel bijgedragen door het Ministerie van Onderwijs, Cultuur en Wetenschap (OCW), het Uitvoeringsinstituut Werknemersverzekeringen (UWV), het UWV WERKbedrijf, het Ministerie van Economische Zaken, Landbouw en Innovatie (EL\&I), de samenwerkende kenniscentra voor beroepsonderwijs en bedrijfsleven COLO, Randstad Nederland en de Raad voor Werk en Inkomen (RWI).

Onze dank gaat uit naar de leden van de begeleidingscommissie en de commissie van financiers voor hun deskundige en enthousiaste begeleiding van het project: Prof. dr. H. Ganzeboom (voorzitter begeleidingscommissie, Vrije Universiteit Amsterdam), drs. R. Baarda (samenwerkende kenniscentra voor beroepsonderwijs en bedrijfsleven COLO), drs. I. Beckers (Centraal Bureau voor de Statistiek), drs. A. Bouman (UWV WERKbedrijf), H. Daale (Leido), drs. S. Deckers (Randstad Nederland), drs. C. van Nahuijs (WerkConsult), drs. F. de Haan (Raad voor Werk en Inkomen), drs. R. Jongsma (Ministerie van Sociale Zaken en Werkgelegenheid), drs. V. Roelse (Ministerie van Binnenlandse Zaken en Koninkrijksrelaties), drs. J. Roosblad (Raad voor Werk en Inkomen), drs. P. Rijnsburger (UWV), drs. M. van Smoorenburg (UWV WERKbedrijf), drs. U. Teunis (Ministerie van Economische Zaken, Landbouw en Innovatie), drs. drs. B. Verlaan (Ministerie van Onderwijs, Cultuur en Wetenschap), drs. M. Warmerdam (Ministerie van Onderwijs, Cultuur en Wetenschap) en dr. I. Waterreus (Onderwijsraad).

Maastricht, december 2OII

Prof. dr. T. Dohmen

Directeur 



\section{Samenvatting}

\section{Werkgelegenheidsgroei concentreert zich in de zorgberoepen}

De economie verkeert in roerige tijden en de vooruitzichten voor economische groei en werkloosheid in 2012 zijn somber. Op de middellange termijn kan er echter weer gerekend worden op enig herstel van de werkgelegenheid. Voor de periode tot 2016 bedraagt de verwachte werkgelegenheidsgroei $0,4 \%$ gemiddeld per jaar. Als gevolg van de sectorale ontwikkelingen zal de werkgelegenheid naar verwachting dalen in alle beroepsklassen, met uitzondering van de medische en paramedische beroepen en de verzorgende en dienstverlenende beroepen. Vooral lager opgeleiden in de verzorgende beroepen hebben voordeel bij de groei van de zorgsector. Nieuwe bezuinigingen in de zorgsector kunnen de op de middellange termijn verwachte groei van de werkgelegenheid echter nog wel in de weg staan.

De conjunctuur drukt een zware stempel op de sectorale werkgelegenheidsontwikkeling. Veel sectoren in de industrie en handel zijn de afgelopen jaren al flink afgeslankt door de crisis, waardoor het personeelsbestand tot een minimum is teruggebracht. Daardoor is er op de middellange termijn weer wat ruimte voor groei van het personeelsbestand. Deze sectoren zullen echter meestal niet meer het werkgelegenheidsniveau van vijf tot tien jaar geleden halen. In andere sectoren zet een meer structurele afbouw van de werkgelegenheid zich voort, hoewel iets minder sterk dan voorheen. Dit lijkt met name het geval te zijn voor de landbouw en visserij en de voedings-, chemie en overige industrie. Bij de overheid en in het onderwijs krimpt de werkgelegenheid naar verwachting, door de bezuinigingen op het ambtenarenkorps in het openbaar bestuur en de dalende leerlingenaantallen in het onderwijs. De werkgelegenheid krimpt procentueel gezien het sterkst bij de groene opleidingen op zowel VMBO- als MBO-niveau en bij de lerarenopleidingen op HBO-niveau. De werkgelegenheid binnen de sectoren horeca en zakelijke dienstverlening en vooral de gezondheidszorg blijft daarentegen stabiel toenemen. 


\section{Baanopeningen tot 2016 ontstaan vooral door vervangingsvraag}

De verwachte baanopeningen ontstaan slechts in beperkte mate door de werkgelegenheidsgroei. Bijna negen op de tien baanopeningen ontstaan de komende jaren vanwege de grote vervangingsvraag, terwijl er bij een op de tien baanopeningen sprake is van uitbreidingsvraag. De verwachte vervangingsvraag bedraagt gemiddeld jaarlijks ca. $4 \%$ van de werkgelegenheid in 2010 , en zal de komende jaren vooral hoog zijn in de transportberoepen en in de sterk vergrijsde agrarische beroepen. Daarentegen is de vervangingsvraag in de informaticaberoepen, met weinig oudere werknemers, het laagst van alle beroepsklassen.

Voor de verschillende beroepsgroepen is onderzocht welk effect het verhogen van de pensioengerechtigdeleeftijd met twee jaar heeft op de vervangingsvraag. Wanneer er twee jaar langer wordt doorgewerkt dringt deze maatregel de totale vervangingsvraag terug met gemiddeld jaarlijks I\%-punt. In de transportberoepen en de agrarische beroepen is de grootste winst te boeken, doordat er in deze beroepsklassen veel ouderen werkzaam zijn. De vervangingsvraag wordt vooral afgeremd bij de conciërges, agrarisch bedrijfshoofden, geestelijk verzorgers en confectie-arbeiders. Voorbeelden van beroepsgroepen waarop deze maatregel geen of nauwelijks effect heeft, zijn elektrotechnici, stewardessen, zweminstructeurs en vakkenvullers.

De vervangingsvraag was altijd al hoog voor de lager opgeleiden. Omdat zij nadat zij op de arbeidsmarkt zijn ingestroomd vaak doorstromen naar een hoger opleidings- en functieniveau, komen er namelijk banen vrij voor nieuwe lager opgeleide schoolverlaters. Ten opzichte van de voorgaande jaren is de grootste toename van de vervangingsvraag echter te verwachten voor de hoger opgeleiden, in het bijzonder voor de lerarenopleidingen en de medische opleidingen.

Het totaal aantal baanopeningen als percentage van de werkgelegenheid zal de komende jaren naar verwachting het grootst zijn bij de agrarische beroepen op lager en middelbaar niveau, en de medische en paramedische beroepen. Op alle opleidingsniveaus ontstaan er veel baanopeningen voor arbeidskrachten met een diploma in de zorg. Voor HBO groen en WO groen, maar ook voor HBO economie en WO economie en recht, worden juist weinig baanopeningen verwacht.

\section{Hoe minder schoolverlaters van een opleiding, hoe beter de arbeidsmarktperspectieven}

In de periode tot 2016 is er een gemiddelde jaarlijkse arbeidsmarktinstroom van schoolverlaters van 3,5\% van de werkgelegenheid in 2010. Dit is lager dan het percentage baanopeningen, waardoor tot 2016 een derde van de schoolverlaters een opleiding zal afsluiten met een goed tot zeer goed arbeidsmarktperspectief. De komende jaren zullen vanuit veel technische en groene opleidingen te weinig schoolverlaters 
op de arbeidsmarkt instromen om aan de vraag te voldoen. Voor enkele grotere bètatechnische opleidingen zoals $\mathrm{MBO}$ en $\mathrm{HBO}$ elektrotechniek en $\mathrm{HBO}$ en WO werktuigbouwkunde en civiele techniek, zijn de arbeidsmarktperspectieven voor schoolverlaters goed door een lage instroom vanuit het onderwijs op de arbeidsmarkt in combinatie met een hoge vervangingsvraag.

Op de meeste opleidingsniveaus is de arbeidsmarktinstroom van schoolverlaters met een economische opleiding relatief groot. Mede daardoor wordt de komende jaren over het algemeen een verslechtering van de arbeidsmarktperspectieven verwacht voor de schoolverlaters van deze opleidingen, ongeacht het opleidingsniveau. Van de MBO'ers die tot 2016 op de arbeidsmarkt instromen heeft ruim een derde goede tot zeer goede vooruitzichten, vooral in de richtingen techniek en de verpleging en verzorging. In de medische en paramedische richtingen zijn de arbeidsmarktperspectieven voor schoolverlaters goed door een combinatie van een hoge uitbreidings- en vervangingsvraag. Voor WO medisch zijn de arbeidsmarktperspectieven het best.

Hoewel VMBO-schoolverlaters over het algemeen goede vooruitzichten hebben op werk, hebben de banen die voor hen beschikbaar zijn meestal betrekking op leerwerkbanen (BBL-trajecten) of banen met een tijdelijk karakter en relatief slechte arbeidsvoorwaarden of weinig rooskleurige loopbaanperspectieven. De mogelijkheden voor een leer-werkbaan zijn het grootst in de technische en verzorgende richtingen. Ongeschoolden zullen de komende jaren daarentegen de meeste moeite hebben om aan het werk te komen doordat de instroom van ongeschoolden op de arbeidsmarkt het aantal baanopeningen voor deze groep overtreft.

\section{Arbeidsmarktsituatie van schoolverlaters is de laatste jaren verslechterd}

Tussen 2006 en 2010 is de arbeidsmarktsituatie voor schoolverlaters op een aantal punten verslechterd. Deze verslechtering wordt weerspiegeld in de toename van de werkloosheid onder schoolverlaters van gemiddeld 6,5\% in 2006 naar bijna $8 \%$ in 20 Io en in de daling van het reële bruto maandloon. Ook moesten in 2010 meer schoolverlaters genoegen nemen met een deeltijdbaan of een flexibel contract en steeg het percentage schoolverlaters dat achteraf spijt had van de gevolgde opleiding enigszins. Een positieve ontwikkeling is echter dat in dezelfde periode iets minder schoolverlaters onder hun niveau of buiten hun vakrichting zijn gaan werken.

Daarnaast zijn er ook duidelijke regionale verschillen. In het Westen van het land is de arbeidsmarktkrapte groter dan in de rest van het land. In het Noorden is de krapte juist minder groot. Voor MBO-schoolverlaters in enkele stedelijke gebieden komt het vaker voor dat er een slechte match is met de beschikbare vacatures dan in sommige landelijke gebieden. Bovendien blijken MBO-schoolverlaters anderhalf jaar na het verlaten van het onderwijs meer tevreden te zijn met de aansluiting tussen hun 
functie en de door hen gevolgde opleiding als er in de regio een ruimere keuze is aan vacatures.

\section{Personeelstekorten het grootst in techniek, zorg, onderwijs en groen}

Voor werkgevers zijn de toekomstige knelpunten in de personeelsvoorziening het grootst als zij personeel willen werven met een technische of zorgopleiding. Er zullen daarentegen tot 2016 over het algemeen weinig wervingsproblemen zijn bij het aantrekken van personeel met een economische achtergrond. In de zorgsector zijn de knelpunten vooral gerelateerd aan de grote uitbreidingsvraag die verband houdt met de toenemende behoefte aan zorg. Dit geldt op alle opleidingsniveaus. Op VMBO- en WO-niveau wordt dit effect versterkt door een hoge vervangingsvraag, en op VMBO-niveau ook nog eens door een lage instroom vanuit het onderwijs op de arbeidsmarkt. Zeer groot zijn de knelpunten bij het aantrekken van verpleeghulpen en leerling-verpleegkundigen, verplegenden en doktersassistenten, therapeuten en verpleegkundigen, artsen en medisch analisten. Maar ook bij de lagere verzorgende en dienstverlenende beroepen ontstaan er zeer grote knelpunten in de personeelsvoorziening bij het werven van ziekenverzorgenden.

Binnen de technische en industrieberoepen worden er over het algemeen zeer grote knelpunten verwacht bij het werven van technisch analisten, werktuigbouwkundigen, weg- en waterbouwkundigen en grafische vakkrachten. Ook voor een aantal beroepen op andere segmenten van de arbeidsmarkt worden grote wervingsproblemen verwacht. Binnen de pedagogische beroepen zullen de knelpunten groot zijn voor onder meer leraren basisonderwijs, docenten exacte, medische en verzorgende vakken, docenten landbouw en techniek (2e graads), docenten talen en expressie, en docenten letteren (Ie graads en WO). Binnen de agrarische beroepen zal het moeilijk worden om voldoende agrarische vakkrachten, milieuhygiënisten en agrarisch vertegenwoordigers, en agrarische bedrijfshoofden aan te trekken.

\section{Opplussen van deeltijdbanen deeloplossing voor de zorg, maar niet voor de techniek}

Voor de technische opleidingen met grote verwachte personeelstekorten zal een beleid dat zich richt op het opplussen van deeltijdbanen weinig zoden aan de dijk zetten. Daarentegen blijkt het tekort aan mensen met een zorgopleiding wel degelijk terug te dringen als de deeltijdbanen in de zorgsector opgeplust kunnen worden. Wanneer alle werkenden met een zorgopleiding op middelbaar niveau minimaal 24 uur gaan werken, verdwijnen de personeelstekorten bij deze opleidingen voor minstens $85 \%$. Het tekort aan personeel met $\mathrm{HBO}$ verpleging neemt in dit scenario met $40 \%$ af. Het personeelstekort voor zorgpersoneel op VMBO-, MBO- of HBO-niveau zou alleen weggewerkt kunnen worden als vrouwen evenveel uren gaan werken als mannen met 
dezelfde opleidingsachtergrond. Maar een dergelijke drastische verandering in het arbeidsaanbod van vrouwen is weinig realistisch. Voor de medische opleidingen op WO-niveau, waar het gemiddeld aantal gewerkte uren al hoog is, helpt het opplussen van deeltijdbanen weinig. Als iedereen die meer wil werken de gewenste arbeidsduur zou kunnen realiseren, leidt dit over het algemeen slechts tot een kleine afname van de verwachte tekorten. In dit scenario is een afname van de personeelstekorten met $24 \%$ het maximaal haalbare voor enkele opleidingen. De tekorten aan personeel met een opleiding $\mathrm{MBO}$ verpleging nemen in dit scenario slechts met $2 \%$ af. Dit illustreert dat het de nodige inspanning zal vergen om het arbeidsaanbod langs deze weg te vergroten.

\section{Nederland deeltijdland heeft voordelen en risico's}

In Nederland wordt er in vergelijking met andere landen veel in deeltijd gewerkt. Met name vrouwen maken in grote mate gebruik van de mogelijkheid om in deeltijd te werken. Zowel mannen als vrouwen zijn tussen 1996 en 2010 in toenemende mate in deeltijd gaan werken. Er blijken vooral veel vrouwelijke deeltijders minder dan 24 uur per week te werken. De hoogste deeltijdpercentages doen zich voor bij de zorgopleidingen op lager en middelbaar niveau. Door deeltijdarbeid kan betaald werk gemakkelijker gecombineerd worden met zorgtaken. De kwaliteit van deeltijdbanen doet in Nederland bovendien niet of nauwelijks onder voor die van voltijdse banen in dezelfde functies.

Ook bedrijven kunnen voordeel hebben bij het aanstellen van deeltijders. Uit onderzoek in de apotheekbranche komt naar voren dat apotheken die relatief meer deeltijders in dienst hebben een hogere arbeidsproductiviteit kennen. De inzet van deeltijders creëert namelijk de mogelijkheid om personeel zeer efficiënt in te zetten. De voordelen van het gebruik van deeltijders zullen afhangen van de mate waarin er voordelen te halen zijn uit een efficiënte allocatie van het personeel. Deze voordelen zullen wellicht het grootst zijn in de detailhandel, de zorgsector en de horeca waar de openingstijden langer zijn dan de voltijdse werkweek en waar er gedurende de werkdag of werkweek schommelingen zijn in de vraag naar personeel.

De keerzijde van deeltijdarbeid is dat voltijders over het algemeen meer werkgerelateerde cursussen volgen dan deeltijders. Werkenden in een kleine deeltijdbaan volgen het minst vaak een dergelijke cursus. Door hun kortere werkweek besteden ze ook minder tijd aan taken waarvan zij kunnen leren. Analyses naar de oorzaak van het verschil in trainingsparticipatie geven aan dat dit grotendeels te wijten is aan een gebrek aan stimulansen van de werkgevers voor het verder ontwikkelen van het menselijk kapitaal van deeltijders. Deeltijders kunnen dit gebrek aan stimulansen van hun werkgever voor een deel compenseren wanneer zij een goed beeld hebben van hun verdere loopbaan en erg gemotiveerd zijn om te leren. 


\section{Grote loongroei met toenemende loonongelijkheid tussen 2001 en 2008}

De vraag- en aanbodontwikkelingen in het verleden komen tot uiting in de beloning van werknemers in de verschillende beroepsklassen. Werknemers in de medische en paramedische beroepen, economische-administratieve beroepen en informaticaberoepen kregen in 2008 een hoog gemiddeld bruto uurloon. Deze beroepen vertoonden ook een relatief sterke loongroei tussen $200 \mathrm{I}$ en 2008 . Werknemers in de agrarische beroepen en de verzorgende en dienstverlenende beroepen verdienden in 2008 het minst en de loonontwikkeling in deze beroepen was negatief in de jaren ervoor. De meestverdienende werknemers binnen een beroepsklasse verdienden in 2008 bijna drie keer zo veel dan de minstverdienenden. Daarnaast blijkt dat de loonongelijkheid binnen beroepen tussen $200 \mathrm{I}$ en 2008 met I $2 \%$ is toegenomen.

\section{Arbeidsmarktinformatie is belangrijk voor beroepskeuze van jongeren}

De keuze van een beroep is een belangrijke beslissing voor jongeren. Het markeert de overgang van school naar werk en is een belangrijke fase in de levenscyclus. De keuze voor het 'juiste' beroep is van groot belang omdat beroepsmobiliteit als gevolg van een verkeerde beroepskeuze kostbaar is voor schoolverlaters, werkgevers en de maatschappij. Economische voorkeuren van jongeren zoals hun risicobereidheid en geduld (als maatstaf voor tijdsvoorkeur) blijken medebepalend te zijn voor hun beroepskeuze. Schoolverlaters met een sterke risicobereidheid kiezen voor beroepen die gekenmerkt worden door een hoge onzekerheid over het inkomen dat ze gaan verdienen. Ook blijken ze vaker te kiezen voor beroepen waarin de conjunctuurgevoeligheid en het risico om werkloos te worden groot zijn. Schoolverlaters die geduldig zijn kiezen vaker voor beroepen die gekenmerkt worden door een steil loonprofiel, dat wil zeggen dat ze in eerste instantie genoegen nemen met een lager startsalaris als ze daarna een grotere loonstijging krijgen. Deze resultaten gaan vooral op voor hoogopgeleiden, wellicht omdat laagopgeleiden meer beperkt zijn in hun beroepskeuzes.

Bovendien blijkt dat personen die 'verkeerde' beroepskeuzes gemaakt hebben, in de zin dat zij werken in een beroep met weinig loonrisico terwijl zij een grote risicobereidheid hebben, of andersom, vaker van beroep veranderen dan personen wiens beroepskeuze wel goed aansluit bij hun economische voorkeuren. Het nieuwe beroep past dan beter bij de persoonlijke economische voorkeuren. Het is dan ook van groot belang dat schoolverlaters over de juiste informatie over dergelijke beroepskenmerken kunnen beschikken. Zo kunnen zij een beroep kiezen dat het beste aansluit bij hun voorkeuren. Over de rol van economische voorkeuren (zoals risicobereidheid en tijdsvoorkeur) bij de beroepskeuze is tot nu toe echter nog relatief weinig bekend.

De onderzoeksuitkomsten wijzen op het belang van het publiceren van gedetailleerde informatie over beroepsrisico's, met betrekking tot de hoogte van het loon, de baanvindkans, de mogelijkheden voor opwaartse loonmobiliteit en andere beroepsrisico's. 
Bovendien wijzen de resultaten er op dat veranderingen in de beloningsstructuur van beroepen onbedoelde effecten kunnen hebben. Zo kan de invoering van variabele beloning of prestatiebeloning weliswaar bijdragen aan een grotere motivatie onder werknemers, maar het vergroot ook het loonrisico. Dat laatste kan er (mogelijk onbedoeld) toe leiden dat het beroep aantrekkelijker wordt voor werkenden met een grote risicobereidheid, maar minder aantrekkelijk voor veel werknemers die het beroep juist ook mede gekozen hadden vanwege het beloningsprofiel in het betreffende beroep. Zij kunnen dan uiteraard ook voor een ander beroep gaan kiezen, maar dergelijke mobiliteit impliceert meestal een verlies van beroepsspecifiek menselijk kapitaal. 



\section{Doel en opzet van de arbeidsmarktprognoses}

\section{Doel}

Dit rapport van het Researchcentrum voor Onderwijs en Arbeidsmarkt (ROA) biedt een overzicht van de huidige en toekomstige ontwikkelingen op de Nederlandse arbeidsmarkt tot 20I6. Het gepresenteerde overzicht heeft als doel inzicht te verschaffen in de actuele situatie en de prognoses van beroepen en opleidingen op de arbeidsmarkt. De prognoses worden elke twee jaar herhaald voor een nieuwe periode van circa vijf jaar. De rapportage vindt plaats in het kader van het door het ROA uitgevoerde Project Onderwijs-Arbeidsmarkt (POA).

Een belangrijke doelgroep van de arbeidsmarktinformatie wordt gevormd door jongeren en werkzoekenden die voor de keuze van een (vervolg)opleiding staan. De gegevens stellen hen in staat hun keuze te funderen op de arbeidsmarktperspectieven die de verschillende opleidingen bieden op de middellange termijn. Deze voorlichtingsfunctie wordt in het bijzonder vervuld via verschillende websites, zoals www.werk.nl, www.studiekeuzeI23.nl en www.kansopwerk.nl. Ook de verschillende keuzegidsen voor het onderwijs (zie bijv. www.keuzegids.org) dragen bij aan de verspreiding van de gegevens onder de doelgroep. Het voorliggende rapport is echter vooral bedoeld voor de beleidsontwikkeling van verschillende groepen van beleidsmakers. Wat betreft de beleidsmakers in het onderwijs kunnen de gegevens nuttig zijn voor onderwijsinstellingen en hun financiers, waaronder het Ministerie van Onderwijs, Cultuur en Wetenschap (OCW) en het Ministerie van Economische Zaken, Landbouw en Innovatie (EL\&I), bijvoorbeeld wanneer wordt overwogen nieuwe opleidingen te beginnen of bestaande aan te passen. Een derde doelgroep zijn de werkgevers en hun brancheorganisaties voor wie de prognose-uitkomsten aanwijzingen geven waar zich in de toekomst knelpunten in de personeelsvoorziening zullen voordoen, zodat zij hierop kunnen anticiperen. In de vierde plaats zijn de arbeidsmarktprognoses bedoeld voor het arbeidsvoorzieningsbeleid. Met name voor het in dit verband gevoerde scholingsbeleid kunnen de prognoses een belangrijke signaalwerking hebben. De gegevens kunnen worden gebruikt door zowel publieke (UWV) als private (uitzend- en re-integratiebureaus) intermediaire organisaties in de 
arbeidsbemiddeling. Ten slotte zijn de prognoses bedoeld voor het arbeidsmarktbeleid in ruime zin. Daarbij kan gedacht worden aan o.a. het doelgroepenbeleid, het beleid gericht op het vergroten van de arbeidsmarktparticipatie en het arbeidsmarktbeleid ten aanzien van de onderkant van de arbeidsmarkt.

\section{Prognosemodel}

Bij het maken van de arbeidsmarktprognoses is uitgegaan van een stroomcijfer-aanpak. Bij deze aanpak worden prognoses gemaakt van de stromen van en naar de arbeidsmarkt in een bepaalde toekomstige periode. Deze benadering heeft als voordeel dat de processen in kaart worden gebracht die van belang zijn voor de ontwikkeling van vraag en aanbod op de arbeidsmarkt. De prognoses worden opgesteld voor in totaal I27 beroepsgroepen en IO2 opleidingstypen, gespreid over de volle breedte van de arbeidsmarkt. Van belang is dat de prognoses, en ook de overige opgenomen arbeidsmarktgegevens, in dit rapport hoofdzakelijk worden gepubliceerd op het niveau van II beroepsklassen en 23 opleidingscategorieën. De onderliggende beroepsgroepen en opleidingstypen zijn opgenomen in Bijlage B van dit rapport.

Figuur I geeft een schematisch overzicht van het prognosemodel. ${ }^{4}$ Een stroomgrootheid die van belang is voor de vraagzijde van de arbeidsmarkt is de uitbreidingsvraag, die de ontwikkeling weergeeft van de werkgelegenheid in een bepaalde beroepsgroep of een bepaald opleidingstype. Voor de berekening van de uitbreidingsvraag naar beroep en opleiding zijn de macro-economische en sectorale ontwikkelingen van groot belang. Hiervoor wordt aangesloten bij de ramingen over de economische groei, de werkgelegenheid en de participatiegraden van het Centraal Planbureau (CPB).

Voor het samenstellen van de arbeidsmarktprognoses in dit rapport is gebruik gemaakt van de Actualisatie Economische Verkenning 5 aangepast met de meer recente inzichten uit het Centraal Economisch Plan $20 I I$ (CEP 20II) en de zogenaamde juniraming ${ }^{6}$, alle van het CPB. In de Economische Verkenning (november 2010) wordt voor de periode $20 I I-20 I 5$ bij een gemiddelde jaarlijkse economische groei van I,25\% uitgegaan van een jaarlijkse daling van de werkgelegenheid in arbeidsjaren van $0,5 \%$ in de marktsector. Voor de zorgsector wordt een jaarlijkse werkgelegenheidsgroei van 2,75\% verwacht en voor de overheid een werkgelegenheidskrimp van $2 \%$ per jaar. Per saldo leidt dit tot een krimp van $0,25 \%$ van de werkzame beroepsbevolking in Nederland.

4. Voor een uitgebreide toelichting wordt verwezen naar ROA, Methodiek arbeidsmarktprognoses en -indicatoren 20II-20I6, Universiteit Maastricht, te verschijnen. Zie Bijlage A voor een verdere uitleg van de begrippen en verwijzingen naar de verschillende onderzoeken die door het ROA zijn uitgevoerd in het kader van de modelbouw.

5. CPB (20I0), Actualisatie Economische Verkenning 20II-20I5 (Verwerking Regeerakkoord), no. 213, november, Den Haag. De in dit rapport veronderstelde macro-economische ontwikkelingen voor 2016 zijn gelijk aan die voor de gemiddelde ontwikkelingen in $201 \mathrm{I}-20 \mathrm{I} 5$.

6. CPB (20II), Centraal Economisch Plan 20II, april, Den Haag; CPB (20II), Juniraming 20II, CPB Policy Brief 20II/o6, Den Haag. 
Figuur 1

Globale opzet prognosemodel

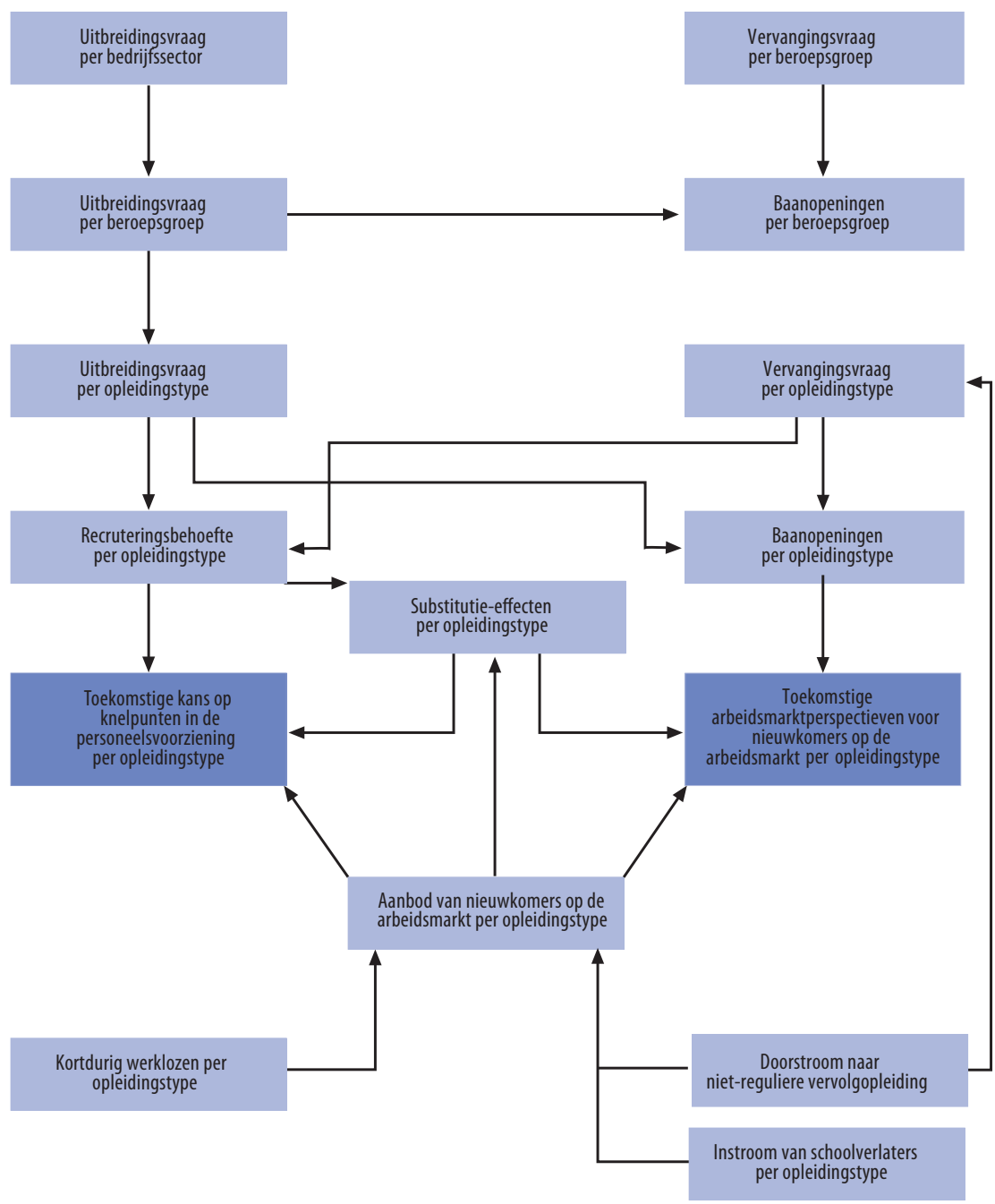

Ter aanvulling op deze middellangetermijnramingen zijn voor $201 \mathrm{I}$ en 2012 de meer recente kortetermijnramingen gebruikt. In dit rapport wordt conform de juniraming van het $\mathrm{CPB}$ uitgegaan van een economische groei van $2 \%$ en $1,75 \%$ in $201 \mathrm{I}$ en 2012 en een toename van het aantal werkzame personen van $0,75 \%$ respectievelijk $1,25 \%{ }^{7}$ In het CEP $20 I I$ wordt bovendien een opsplitsing gegeven voor enkele sectoren. ${ }^{8} \mathrm{De}$ macro-economische en sectorprognoses van het $\mathrm{CPB}$ zijn door het EIM op verzoek

7. Dit is wat positiever dan in de meer recente $M E V 20 I 2$.

8. De $M E V 20 I 2$ en de juniraming bevatten geen sectorale differentiatie; de CEP $20 I I$ en de Economische Verkenning bevatten een beperkte differentiatie. 
van het ROA gedifferentieerd naar I5 verschillende bedrijfssectoren. Voor deze differentiatie naar bedrijfssectoren is gebruik gemaakt van verdeelmodellen. ${ }^{9}$ Het betreft hier niet alleen de sectorprognoses voor de werkgelegenheid, maar ook voor de toegevoegde waarde, de investeringen in kapitaal en de P/A-ratio (i.e. personen versus arbeidsjaren), waarbij zoveel mogelijk is uitgegaan van het macro-economische kader van het $\mathrm{CPB}$.

In aansluiting op de prognoses van de uitbreidingsvraag voor bedrijfssectoren worden door het ROA prognoses gemaakt van de verschuivingen in de beroepenstructuur binnen de onderscheiden bedrijfssectoren. Hierdoor kan er rekening gehouden worden met het feit dat binnen een bedrijfssector bepaalde beroepsgroepen zich sneller ontwikkelen dan andere. Voorts zijn er in het zogenaamde beroepenmodel van de uitbreidingsvraag, naast de ontwikkeling van de omvang en structuur van de werkgelegenheid, verschillende verklarende variabelen (o.a. toegevoegde waarde en investeringen) gebruikt om de prognoses van de uitbreidingsvraag naar beroep samen te stellen. ${ }^{\text {Io }}$ Vervolgens wordt bepaald welke implicaties de voorspelde groei van de verschillende beroepsgroepen heeft voor de uitbreidingsvraag per opleidingstype. Hierbij wordt rekening gehouden met het optreden van verschuivingen in de opleidingenstructuur binnen beroepsgroepen. ${ }^{\text {II }}$ De uitbreidingsvraag per opleidingstype heeft betrekking op het aantal personen met een bepaalde opleidingsachtergrond die werkgevers zouden willen aannemen om te kunnen voorzien in een grotere vraag naar goederen en diensten. De feitelijke ontwikkeling van het aantal werkenden per opleidingstype zal hier doorgaans van afwijken door de interactie met de aanbodzijde van de arbeidsmarkt, en de als gevolg daarvan optredende substitutieprocessen. ${ }^{\mathrm{I2}} \mathrm{Bij}$ de analyse van de werkgelegenheidsontwikkeling naar beroep en opleiding wordt intensief gebruik gemaakt van de Enquête Beroepsbevolking van het CBS.

Naast uitbreidingsvraag is er op de arbeidsmarkt sprake van vervangingsvraag door - al dan niet vervroegde - pensionering, arbeidsongeschiktheid, tijdelijke terugtreding van de arbeidsmarkt, beroepsmobiliteit, e.d. Om de uitstroom te bepalen worden tevens veronderstellingen gemaakt ten aanzien van de participatiegraden in de verschillende cohorten. Hiervoor is uitgegaan van de CPB-prognoses van de bruto participatiegraden per cohort en geslacht. ${ }^{13}$ Er wordt overigens alleen van vervangings-

9. T. Kwaak en S. Tan (2006), PRISMA-K: een bedrijfstakkenmodel voor de korte termijn, SCALES-paper, Zoetermeer; T. Kwaak (2006), PRISMA-M: een bedrijfstakkenmodel voor de middellange termijn, SCALES-paper, Zoetermeer.

Io. F. Cörvers en A. Dupuy (2007), Beroepenmodel voor het onderwijs en de zorg: werkgelegenheid en prognoses, ROA-W-2007/3, Universiteit Maastricht; F. Cörvers en A. Dupuy (2010), 'Estimating employment dynamics across occupations and sectors of industry', Journal of Macroeconomics, Vol. 32, pp. I7-27.

II. A. Dupuy (2006), Measuring Skill-upgrading in the Dutch Labor Market, ROA-W-2006/3E, Universiteit Maastricht.

I2. F. Cörvers en H. Heijke (2004), Forecasting the labour market by occupation and education: Some key issues, ROA-W-2004/4, Universiteit Maastricht.

I3. R. Euwals en K. Folmer (2009), Arbeidsaanbod en gewerkte uren tot 2050, Een beleidsneutraal scenario, CPB Memorandum No. 225, 23 april, Den Haag. 
vraag gesproken voor zover het vertrek van een werknemer ook daadwerkelijk leidt tot vraag naar een nieuwkomer. Als het vertrek van een arbeidskracht gebruikt wordt om een werkgelegenheidskrimp te effectueren, is er geen sprake van vervangingsvraag. Deze uitstroom is immers niet relevant voor nieuwkomers. Dit betekent dat niet de volledige arbeidsmarktuitstroom daadwerkelijk leidt tot vervangingsvraag.

Er is een belangrijk verschil tussen de vervangingsvraag per beroepsgroep en per opleidingstype. De beroepsmobiliteit is namelijk wel van invloed op de vervangingsvraag per beroepsgroep, maar heeft geen effect op de vervangingsvraag per opleidingstype. Het veranderen van beroep heeft immers geen gevolgen voor de opleidingsstructuur van de werkgelegenheid. Daarentegen kan een werkende door het afronden van een vervolgopleiding in feite 'uitstromen' naar een ander opleidingstype. In dat geval is er sprake van een vervangingsvraag bij het opleidingstype waartoe de vooropleiding van deze werkende wordt gerekend. Voor het vaststellen van de uitstroompatronen naar beroep en opleiding wordt eveneens gebruik gemaakt van de Enquête Beroepsbevolking van het CBS.

Bij toename van de werkgelegenheid vormen de uitbreidingsvraag en de vervangingsvraag tezamen de baanopeningen voor nieuwkomers op de arbeidsmarkt. Bij krimpende werkgelegenheid kan er alleen sprake zijn van baanopeningen uit hoofde van vervangingsvraag.

Tegenover de totale vraag naar nieuwkomers staat het verwachte aanbod van nieuwkomers, dat bestaat uit de toekomstige arbeidsmarktinstroom van schoolverlaters en de doorstroom naar een ander opleidingstype vanwege het afronden van postinitiële vervolgopleidingen in de prognoseperiode en het nog boven de markt zwevende aanbod van kortdurig werklozen aan het begin van deze periode. Verondersteld wordt dat langdurig werklozen, die langer dan een jaar op zoek zijn naar werk, geen serieuze concurrenten meer vormen voor schoolverlaters. De prognoses van de instroom van schoolverlaters op de arbeidsmarkt hebben als uitgangspunt de Referentieraming $20 I I$ van het Ministerie van Onderwijs, Cultuur en Wetenschap met betrekking tot de verwachte uitstroom uit het initiële onderwijs. Door het ROA zijn deze prognoses nader verbijzonderd en aangevuld met prognoses van de doorstroom naar het postinitiële onderwijs, waarbij o.a. gegevens uit de Onderwijsmatrix en de Enquête Beroepsbevolking van het CBS en gegevens uit het Schoolverlatersinformatiesysteem (SIS) van het ROA zijn gebruikt. ${ }^{\mathrm{I}}$

Door de verwachte vraag- en aanbodstromen met elkaar te confronteren wordt per opleidingstype een indicatie verkregen van de toekomstige arbeidsmarktperspectieven voor nieuwkomers op de arbeidsmarkt. De waarde van de Indicator Toekomstig Arbeidsmarktperspectief (ITA) geeft aan welke vraag-aanbod-discrepantie er per opleidingstype te verwachten is. Als het arbeidsaanbod kleiner is dan de vraag, en de ITA

I4. F. Cörvers en B. Golsteyn (2003), De invloed van voortijdige schooluitval op de instroomprognoses van schoolverlaters op de arbeidsmarkt, ROA-W-2003/I, Universiteit Maastricht. 
dus kleiner dan of gelijk is aan I,oO, wordt het arbeidsmarktperspectief als goed getypeerd. Als de waarde van de ITA zelfs kleiner dan of gelijk is aan 0,85 dan wordt gesproken van een zeer goed arbeidsmarktperspectief. ${ }^{\text {Is }}$ Wanneer de ITA daarentegen een waarde heeft tussen de I,OO en I,O5 en het aanbodoverschot niet veel groter is dan wat als frictie kan worden beschouwd, wordt gesproken van een redelijk arbeidsmarktperspectief. Bij een hogere waarde van de ITA wordt het arbeidsmarktperspectief voor het desbetreffende opleidingstype als matig, of als de ITA zelfs groter is dan I,I5, als slecht aangeduid.

Een aanbodoverschot impliceert echter niet vanzelfsprekend dat de desbetreffende groep werkloos zal worden en een aanbodtekort betekent niet automatisch dat er sprake zal zijn van onvervulde vacatures. Het is immers ook mogelijk dat werkgevers hun eisen aanpassen en mensen aannemen met een andere opleidingsachtergrond dan aanvankelijk gevraagd werd. Schoolverlaters met een opleiding waarvoor het aanbod de vraag overtreft ervaren in een dergelijke situatie een verslechtering van hun positie doordat zij bijvoorbeeld vaker beneden hun niveau of buiten hun vakrichting moeten werken, slechter beloond worden of vaker genoegen moeten nemen met deeltijdwerk, terwijl men liever een voltijdsbetrekking had. ${ }^{16}$ Omgekeerd zal bij een tekortschietend aanbod de positie van schoolverlaters verbeteren. Deze hoeven in dat geval minder vaak genoegen te nemen met een functie op een lager niveau, een lagere beloning e.d.

Bij de opleidingen die door opleidingstypen met een aanbodoverschot worden verdrongen, zal het aantal baanopeningen vanwege dit substitutieproces kleiner worden. Daarentegen zal er voor de opleidingen die verwant zijn aan de opleidingen met een tekortschietend aanbod juist sprake zijn van extra baanopeningen. Deze passieve substitutie-effecten zijn derhalve, wanneer er sprake is van knelpunten, van belang voor de arbeidsmarktperspectieven van de desbetreffende opleidingen.

De vraag-aanbod-confrontatie geeft voor elk opleidingstype ook een indicatie van de toekomstige knelpunten in de personeelsvoorziening. Daarbij bepalen de uitbreidingsen vervangingsvraag samen de recruteringsbehoefte per opleidingstype. Bij krimpende werkgelegenheid voor een bepaald opleidingstype wordt deze recruteringsbehoefte op een andere wijze berekend dan het aantal baanopeningen voor nieuwkomers op de arbeidsmarkt. In dat geval bestaat immers vanuit het perspectief van bedrijven de mogelijkheid om de gedwongen uitstroom van het zittende personeel te verminderen. Zeker wanneer bedrijven geconfronteerd worden met een krappe arbeidsmarkt voor een bepaald opleidingstype, mag worden aangenomen dat zij van deze mogelijkheid gebruik zullen maken.

I5. Deze grenzen zijn gebaseerd op een statistische analyse van de spreiding van de arbeidsmarktsituatie van de verschillende opleidingstypen. Zie M.H. Wieling, A. de Grip en E.J.T.A. Willems (1990), Een systematische kwalitatieve typering van arbeidsmarktinformatie, ROA-W-1990/8, Universiteit Maastricht. Zie voor een analyse van de betekenis van de ITA ook A. Dupuy (2009), An evaluation of the forecast of the indicator of the labour market gap, ROA-TR-2009/3, Universiteit Maastricht.

I6. M. Wieling en L. Borghans (200I), 'Discrepancies between supply and demand and adjustment processes in the labour market', Labour, Vol. I5, pp. 33-56. 
In dit rapport staat het in kaart brengen van de aansluitingsproblematiek tussen onderwijs en arbeidsmarkt verbijzonderd naar de onderscheiden opleidingstypen centraal. In aanvulling daarop wordt inzicht gegeven in de implicaties die de vraag-aanbodverhoudingen voor de onderscheiden opleidingstypen hebben voor de knelpunten in de personeelsvoorziening per beroepsgroep. Inzicht in de knelpunten naar beroepsgroep is voor verschillende gebruikers en gebruiksdoelen relevant. Voor werkgevers kan inzicht in de knelpunten naar beroepsgroep van belang zijn voor hun wervings- en personeelsbeleid. Op de tweede plaats kunnen (langdurig) werklozen of werkenden die op zoek zijn naar een andere werkkring gebruik maken van de informatie in hun oriëntatie naar een nieuwe of andere werkkring. Nauw met dit tweede gebruiksdoel samenhangend zijn de bij- en omscholingsprogramma's die doorgaans gericht zijn op een bepaalde beroepsgroep. Inzicht in de knelpunten naar beroep kan derhalve een leidraad zijn bij het opzetten van dergelijke scholingsprogramma's.

De totale verwachte vraag in de prognoseperiode in het betreffende beroep wordt in dit rapport gerelateerd aan enerzijds de wijze waarop werkgevers de vraag beogen in te vullen qua opleidingsachtergrond van de arbeidskrachten en anderzijds de vraagaanbodverhoudingen voor de voor dat beroep relevante opleidingstypen. Hierdoor wordt een indicatie verkregen van de problemen die werkgevers bij het werven van personeel zullen ondervinden. Wanneer voor een bepaald beroep kennis en vaardigheden vereist zijn die met name aanwezig zijn bij mensen met een bepaalde opleidingsachtergrond waarvoor grote tekorten worden verwacht, zullen werkgevers veel moeite hebben personeel te vinden dat over de in dat beroep vereiste kwalificaties beschikt. Wanneer het hier over zeer beroepsspecifieke expertise gaat, zullen de knelpunten extra groot zijn, aangezien er in dat geval weinig alternatieven voorhanden zijn. Wanneer het daarentegen meer algemene competenties betreft, kan de werkgever doorgaans mensen met een andere opleidingsachtergrond aantrekken.

In veel gevallen wordt in dit rapport, naast een getalsmatige indicatie, een kwalitatieve typering gegeven van de prognose. Het doel van deze kwalitatieve typeringen is tweeledig. Enerzijds vereenvoudigt de typering de interpretatie van de cijfers. Anderzijds wordt door middel van deze kwalitatieve typeringen rekening gehouden met de onzekerheidsmarges waarmee het opstellen van prognoses gepaard gaat. 



\section{De arbeidsmarkt in vogelvlucht}

\section{$1.1 \quad$ Inleiding}

In dit hoofdstuk worden de ontwikkelingen op de arbeidsmarkt op hoofdlijnen weergegeven voor de periode tot 20I6. In de volgende paragraaf wordt eerst teruggekeken op de ontwikkeling van de economische groei en werkloosheid in Nederland. Tevens wordt daarbij ingegaan op de verschillen tussen regio's wat betreft werkloosheid en vacaturegraad. Vervolgens wordt er gekeken naar de verwachte toekomstige macroeconomische ontwikkelingen wat betreft de werkgelegenheid, de uitstroom van de arbeidsmarkt, het totaal aantal baanopeningen en de instroom van schoolverlaters op de arbeidsmarkt. De verwachte werkgelegenheidsontwikkelingen op de middellange termijn worden verbijzonderd naar bedrijfssector, beroepsklasse en opleidingsniveau in respectievelijk de paragrafen I.3, I.4 en I.5. In paragraaf I.6 wordt er per opleidingsniveau aan de hand van de verwachte vraag- en aanbodontwikkelingen op de middellange termijn weergegeven wat de perspectieven van schoolverlaters en afgestudeerden op de arbeidsmarkt tot 2016 zijn. Het hoofdstuk sluit af met de conclusies.

\subsection{Actuele situatie en verwachte ontwikkeling}

\section{Werkloosheid, vacatures en regionale verschillen}

De beslissingen die werkgevers nemen over hun personeel zijn de schakel tussen enerzijds economische groei en anderzijds vacatures en werkloosheid. In het rapport Werkgevers over de crisis $^{17}$ kijkt het Sociaal en Cultureel Planbureau (SCP) terug op de anticipatie van het bedrijfsleven op de economische crisis die in 2008 begon en de

I7. E. Josten (20II), Werkgevers over de crisis, Sociaal en Cultureel Planbureau, SCP-publicatie 2OII-I4, Den Haag, april. In het rapport wordt gebruik gemaakt van het Arbeidsvraagpanel (AVP) dat het SCP sinds 2010 heeft overgenomen van de Organisatie voor Strategisch Arbeidsmarktonderzoek (OSA). Het panel bevat sinds de start in 1989 gegevens over ca. 2.500 werkgevers in alle sectoren op basis van een min of meer vaste vragenlijst. Werkgevers worden in een tweejaarlijkse cyclus drie of vier keer bevraagd. De verschillende interviewrondes maken het mogelijk om de antwoorden van werkgevers te vergelijken met de ontwikkeling van het bruto binnenlands product (bbp) en de werkloosheid gedurende de economische cyclus. Dit wordt in het rapport gedaan door de laatste twee economische crises (200I-2003 en 2008-20IO) te analyseren. 
personele maatregelen die werkgevers troffen naar aanleiding van die crisis. Er wordt bekeken hoe werkgevers zijn omgegaan met het overtollige personeel in de ergste crisis in 65 jaar, en waarin hun maatregelen verschilden van die in de vorige crisis van 200I2003. Duidelijk is dat de vorige crisis relatief veel kwartalen van afwisselend lichte groei en krimp kende, terwijl de laatste zich veel sneller voltrok. Omdat werkgevers de plotselinge en diepe crisis helemaal niet hadden zien aankomen, hadden zij weinig tijd om het personeelsbestand in te krimpen. Daardoor daalde de arbeidsmarktproductiviteit (productie per gewerkt uur) tussen 2008 en 2009 zeer sterk, waar de arbeidsproductiviteitsgroei in de vorige crisis slechts vertraagde.

De effecten van de conjunctuurcyclus op de arbeidsmarkt zijn duidelijk zichtbaar in de veranderingen van het aantal vacatures en werklozen in het afgelopen decennium. Als de economische groei aantrekt vertaalt dit zich in meer vacatures, en vervolgens met enige vertraging in een lagere werkloosheid. Het verband tussen vacaturegraad en werkloosheidspercentage is dus negatief: een stijgend (dalend) aantal vacatures leidt tot minder (meer) werklozen. Dit verband staat bekend staat als de 'unemploymentvacancy' (UV) curve, ofwel de 'Beveridge' curve. Doordat de werkloosheid later reageert op veranderingen in de economische groei dan de vacaturegraad ontstaan er cirkels in de figuur die de UV-curve weergeeft.

Op basis van gegevens van het Centraal Planbureau (CPB) en het Centraal Bureau voor de Statistiek (CBS) worden hieronder de curves weergegeven voor Nederland als geheel vanaf 2000, en voor de vier verschillende landsdelen. ${ }^{{ }^{8}}$ Uit figuur I.I is af te lezen dat het aantal openstaande vacatures aan het begin van het vorig decennium een hoogtepunt bereikte, waarna de economische groei stagneerde en de vacaturegraad fors daalde van meer dan 25 vacatures per I.00o banen naar minder dan I5 in 2003. Door fluctuaties aan de vraagzijde van de arbeidmarkt kunnen er 'loopings' tegen de klok in ontstaan zoals tussen de jaren 2000 en $2005 .{ }^{19}$ Een lagere economische en werkgelegenheidsgroei leidt dan aanvankelijk tot een dalende vacaturegraad bij gelijkblijvende werkloosheid. Voor werkgevers is het immers gemakkelijker de werving van nieuw personeel te stoppen in plaats van het personeelsbestand in te krimpen. De werkloosheid reageert dus vertraagd op de economische ontwikkeling. Als de werkloosheid begint op te lopen, is de werkgelegenheid op een aantal segmenten van de arbeidsmarkt alweer aan het toenemen. Daardoor stijgt de vacaturegraad. De werkloosheidsontwikkeling reageert wederom vertraagd, en daalt pas na enige tijd.

Vanaf 2004 begon de economie weer flink te groeien, tot deze aan het eind van 2008 tot stilstand kwam, en in 2009 kromp met een na de oorlogsjaren in Nederland niet eerder vertoonde $3,5 \%$. Dit resulteerde in een sterk afnemende vacaturegraad en oplo-

I8. De reeks voor Nederland is afkomstig van bijlage e7 uit de $M E V 20 I 2$ van het CPB. De vacature- en werkloosheidgegevens van de landsdelen zijn een bewerking van arbeidsmarktgegevens op Statline van het CBS.

19. Door fluctuaties in het arbeidsaanbod ontstaan 'loopings' met de klok mee. 
pende werkloosheid. ${ }^{20}$ In de eerder genoemde studie van het Sociaal en Cultureel Planbureau wordt onderzocht of de antwoorden van werkgevers op enquêtevragen licht kunnen werpen op hoe bedrijven en instellingen met hun werknemers zijn omgegaan in de crisistijd. Van de werkgevers in de marktsector met overtollig personeel gaf bijna $40 \%$ van de werkgevers in het Arbeidsvraagpanel van het SCP aan dat ze goede krachten in dienst willen houden omdat ze later weer hard nodig zijn ('labour hoarding'). Andere belangrijke redenen om werknemers is dienst te houden zijn dat de hoeveelheid werk waarschijnlijk spoedig weer groeit, en dat ontslag duur is of lastig te regelen. Van de werkgevers in de marktsector met overtollig personeel heeft I6\% gebruik gemaakt van werktijdverkorting (wtv) en/of deeltijd-ww (voor alle werkgevers in de marktsector is dat IO\%). Voorts wordt er in het rapport op gewezen dat individueel ontslag gemakkelijker is geworden en goedkoper door aanpassing van de kantonrechtersformule, op het grotere aantal flexibele krachten (tijdelijk personeel en zelfstandigen ${ }^{21}$ dan bij aanvang van de vorige crisis. Uit het Arbeidsvraagpanel blijkt dat werkgevers in de marktsector in de laatste ten opzichte van de vorige crisis inderdaad vaker individueel ontslag hebben toegepast, vaker tijdelijke contracten niet hebben verlengd, en vaker het aantal gewerkte uren hebben beperkt. ${ }^{22}$ Overigens kon het tijdelijke personeel dat geen baan meer had relatief snel weer aan de slag door de hoge vacaturegraad bij aanvang van de crisis in 2008 , in het bijzonder bij minder conjunctuurgevoelige sectoren als de zorg en de overheid.

In 2010 bevindt de Nederlandse arbeidsmarkt zich wat betreft vacatures en werkloosheid op bijna hetzelfde punt als in 2003 . Toch lijken de vooruitzichten anders te zijn. Enerzijds wordt er in de Macro Economische Verkenning 2012 van het CPB een lagere groei voorspeld voor 20 II en 2012 (respectievelijk I,5 en I,O\% groei) dan in 2004 en 2005 werd gerealiseerd (respectievelijk 2,2 en 2,0\% groei), anderzijds zal volgens het $\mathrm{CPB}$ de werkloosheid minder toenemen dan toen. Volgens het CPB zal de werkloosheid in $201 \mathrm{I}$ op $5 \%$ uitkomen, en in 2012 op 5,25\%. De geringe stijging van de werkloosheid verklaart het $\mathrm{CPB}$ door de terughoudendheid van werkgevers om personeel te ontslaan. Deze terughoudendheid kunnen ze zich volgens het CPB permitteren door hun relatief goede financiële positie aangaande de solvabiliteit. Wellicht speelt hierbij ook een rol dat werkgevers hopen de periode van relatief lage economische groei in $201 \mathrm{I}$ en 2012 te kunnen overbruggen met het in dienst houden van gekwalificeerd en ervaren personeel waarvoor ze na deze periode grote schaarste op de arbeidsmarkt verwachten ('labour hoarding'). Dit is niet onwaarschijnlijk als de arbeidsmarkt zich in de periode 20II-20I5 ontwikkelt als tussen 2004-2008, met een sterk oplopende vacaturegraad zoals figuur I.I laat zien.

20. Toch steeg de werkloosheid veel minder dan het CPB had verwacht. In de door het CPB uitgebrachte Macro Economische Verkenning 2010 van september 2009 wordt een werkloosheid van $8 \%$ in 2010 verwacht, terwijl de gemiddelde werkloosheid in 20 Io op 5,4\% uitkwam.

2I. Zie hiervoor F. Cörvers, A. de Grip en R. Euwals (2010), Labour Market Flexibility in the Netherlands, The role of contracts and self-employment, CPB-ROA publicatie, Den Haag.

22. Dat laatste vooral buiten wtv en deeltijd-ww om. 


\section{Figuur 1.1}

Relatie tussen vacaturegraad en werkloosheidspercentage op de Nederlandse arbeidsmarkt, 20002010

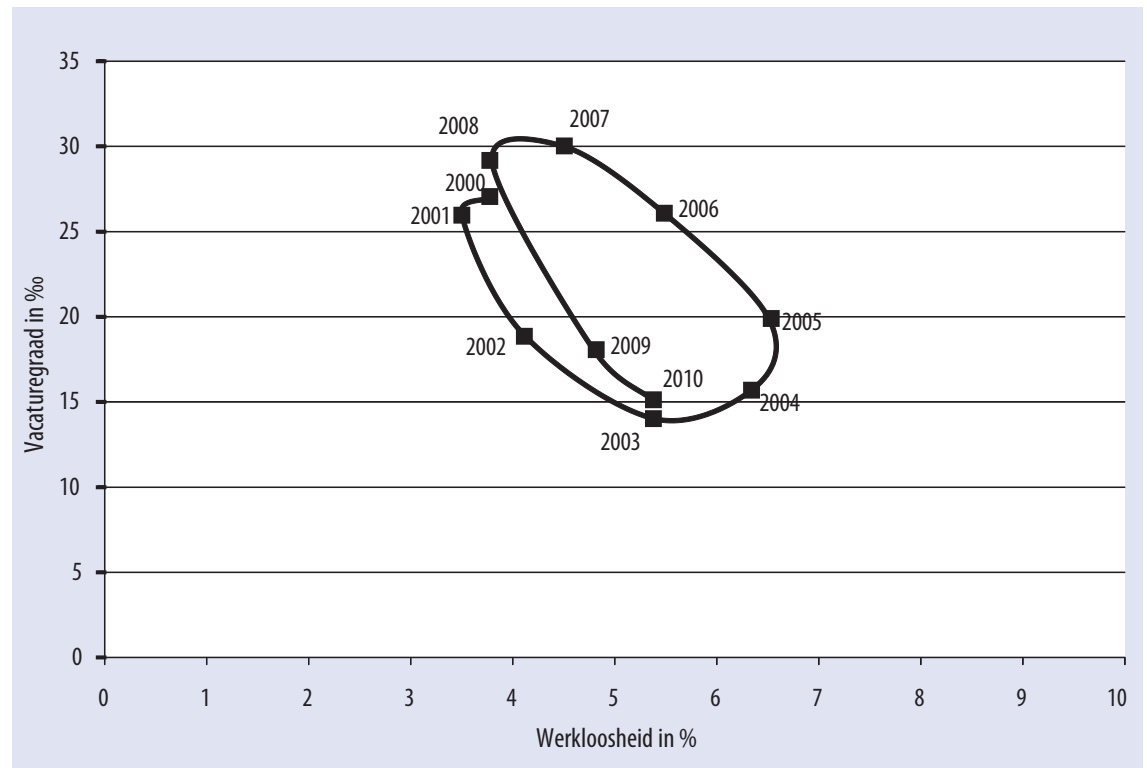

Bron: $\mathrm{CPB} / \mathrm{CBS}$

Gezien de sterk toegenomen aandacht in Nederland voor regionale arbeidsmarkten wordt er in deze paragraaf ook enige aandacht besteed aan regionale verschillen in vacatures en werkloosheid. In figuur I.2 worden voor de vier landsdelen de UV-curves weergegeven op basis van door het ROA bewerkte gegevens van het CBS. Meer recente vacaturegegevens van het CBS ontbreken echter. De gegevens van 20IO zijn nog niet beschikbaar, en in de jaren 2005, 2007 en 2009 werd er geen vacatureenquête gehouden die een regionale uitsplitsing mogelijk maakte. De verschillende arbeidsmarktsituaties in de vier landsdelen zijn echter goed af te leiden uit figuur I.2. Alleen het begin- en eindjaar zijn in de figuur aangegeven.

Uit figuur I.2 blijkt dat het Noordelijke landsdeel over de periode 2000-2008 de hoogste werkloosheid en laagste vacaturegraad had. Dit is in overeenstemming met het heersende beeld dat de arbeidsmarkt in het Noorden het minst te lijden heeft aan personeelsschaarste bij bedrijven, en dat voor werklozen het aantal beschikbare banen beperkt is. Voor de andere landsdelen is de verhouding tussen vacatures en werkloosheid gunstiger voor werkzoekenden: de UV-curves schuiven telkens meer naar linksboven voor achtereenvolgens het Oosten, het Zuiden en het Westen. De UV-curve voor het Oostelijke en Zuidelijke landsdeel geeft een structureel lagere werkloosheid en een structureel hogere vacaturegraad aan dan voor het Noorden. In het Westen neemt de werkloosheid als gevolg van de recessie minder sterk toe dan in de andere 
landsdelen, terwijl in hoogtijdagen de vacaturegraad juist veel sterker toeneemt dan in de rest van het land.

Figuur 1.2

Relatie tussen vacaturegraad en werkloosheidspercentage op de arbeidsmarkt van de vier landsdelen, 2000-2008

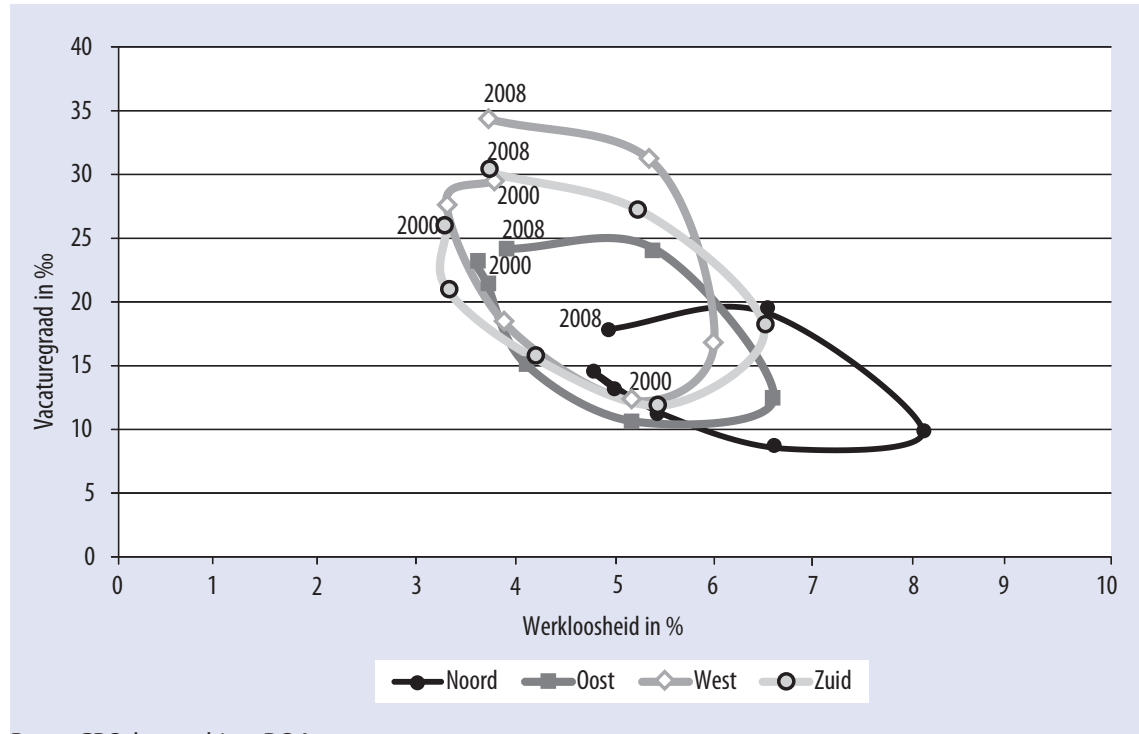

Bron: $\mathrm{CBS}$, bewerking ROA

De regionale aansluiting tussen onderwijs en arbeidsmarkt is vooral van belang voor de lager en middelbaar opgeleiden. Verschillen in vraag en aanbod tussen regionale arbeidsmarkten, die kunnen worden weergegeven door de verhouding tussen vacatures ten opzichte van werklozen in verschillende regio's, zijn voor hoger opgeleiden vaak minder groot doordat de geografische mobiliteit van hoger opgeleiden relatief groot is. $\mathrm{Zij}$ zijn dus eerder bereid te verhuizen of grotere reisafstanden af te leggen bij het aanvaarden van een baan in een andere regio waardoor de vacatures worden ingevuld en de werkloosheid laag blijft. Voor de lagere opleidingsniveaus zijn de regionale arbeidsmarktontwikkelingen derhalve belangrijker dan voor de hogere.

Wanneer een UV-curve in meer noordoostelijke richting is gelegen, i.e. een hogere werkloosheid bij dezelfde vacaturegraad of een hogere vacaturegraad bij dezelfde werkloosheid, kan dit duiden op een grotere mismatch op de arbeidsmarkt. Vraag en aanbod op de arbeidsmarkt kunnen daar slechter op elkaar aansluiten doordat door werkgevers gevraagde en door werkzoekenden aangeboden competenties minder goed op elkaar aansluiten. Daarnaast is het mogelijk dat de arbeidsmarkt minder efficiënt functioneert doordat de transparantie op de arbeidsmarkt lager is dan elders en de registratie van werklozen en vacatures trager verloopt, waardoor werklozen en werkgevers langer moeten zoeken om een passende baan c.q. geschikte kandidaat te vinden. 
Andere mogelijke oorzaken die vaak aangedragen worden zijn een lagere zoekintensiteit van werkzoekenden of een grotere kieskeurigheid van werkgevers. ${ }^{23}$

Figuur I.3 geeft door middel van een UV-curve het lineaire verband weer tussen de vacaturegraad en het werkloosheidspercentage voor $\mathrm{MBO}$-schoolverlaters van de 40 Nederlandse COROP-gebieden in 2008. ${ }^{24}$ Elk punt in de figuur laat voor het bijbehorende COROP-gebied zien hoe hoog het werkloosheidspercentage van $\mathrm{MBO}$-gediplomeerden is bij een gegeven vacaturegraad in dat gebied. De vraagzijde van de arbeidsmarkt is hier 'driver', i.e. wanneer het aantal openstaande vacatures in een regio stijgt of daalt dan resulteert dit in een effect op het werkloosheidsniveau in die regio. De middelste lijn in Figuur I.3 geeft het geschatte lineaire verband weer tussen de vacaturegraad en het werkloosheidspercentage voor $\mathrm{MBO}$-gediplomeerden voor de verschillende regio's in 2008. In het algemeen kan gesteld worden dat er sprake is van een significant negatief verband $(-0,353)$ tussen het aantal openstaande vacatures en het werkloosheidsniveau in de onderzochte regio's. Dit negatieve verband is significant bij een $95 \%$ betrouwbaarheidsinterval ( $\mathrm{p}$-waarde $=0,017$ ). Hoe meer werkloosheid er dus voor een gegeven vacaturegraad is, hoe slechter de aansluiting. De COROP-gebieden Oost-Zuid-Holland (punt 28), Midden-Noord-Brabant (punt 34), Zuidwest-Overijssel (punt II) en Alkmaar en omgeving (punt I9) bevinden zich op (of vlakbij) de middelste geschatte lijn. De regionale aansluiting tussen vraag en aanbod in deze regio's is dus als gemiddeld te typeren.

De bovenste lijn en de onderste lijn in de figuur duiden de bandbreedte aan en geven respectievelijk weer of er sprake is van een slechte dan wel een goede aansluiting tussen vraag en aanbod op de arbeidsmarkt. ${ }^{25}$ Een aantal COROP-gebieden bevinden zich buiten de geschetste bandbreedte. Zo valt Kop van Noord-Holland (punt I8) ver onder de bandbreedte. Dit betekent dat er, gegeven de vacaturegraad in de Kop van Noord-Holland, een relatief lage werkloosheid in deze regio is. Derhalve kan vastgesteld worden dat de aansluiting tussen vraag en aanbod op deze regionale arbeidsmarkt beter dan gemiddeld is. Hetzelfde geldt voor Zuidwest-Friesland (punt 5). Voor Utrecht (punt 17), Agglomeratie Haarlem (punt 2I) en Groot-Amsterdam (punt 23) is er echter sprake van een slechte aansluiting, omdat zij zich boven de bandbreedte bevinden. De regionale aansluiting van Groot-Rijnmond (punt 29) ligt daarbij nog net op de grens. Enkele verstedelijkte COROP-gebieden laten dus een slechte regi-

23. C. Gorter en J. van Ours (1994), 'Matching Unemployment and Vacancies in Regional Labor Markets: An Empirical Analysis for the Netherlands', Papers in Regional Science, Vol. 73, pp. 153-I67.

24. De gegevens van de MBO-schoolverlaters zijn afkomstig uit de ROA-schoolverlatersenquêtes en hebben betrekking op schoolverlaters die anderhalf jaar na het verlaten van het onderwijs werkzaam of werkloos zijn. De vacaturegegevens zijn afkomstig van het CBS en gebaseerd op het zogenaamde structuuronderzoek.

25. Bij de keuze voor deze bandbreedte is enige mate van voorzichtigheid in acht genomen en daarom is de bandbreedte vastgesteld op maar liefst acht maal de standaarddeviatie. Dit om ervoor te zorgen dat alleen die COROP-gebieden getypeerd worden als gebieden met een goede c.q. slechte aansluiting, die ook daadwerkelijk veel van het gemiddelde afwijken. 
onale aansluiting zien, in tegenstelling tot enkele landelijke gebieden met een goede regionale aansluiting.

Figuur 1.3

Relatie tussen vacaturegraad en werkloosheidspercentage van MBO-schoolverlaters voor 40 COROP-gebieden, 2008

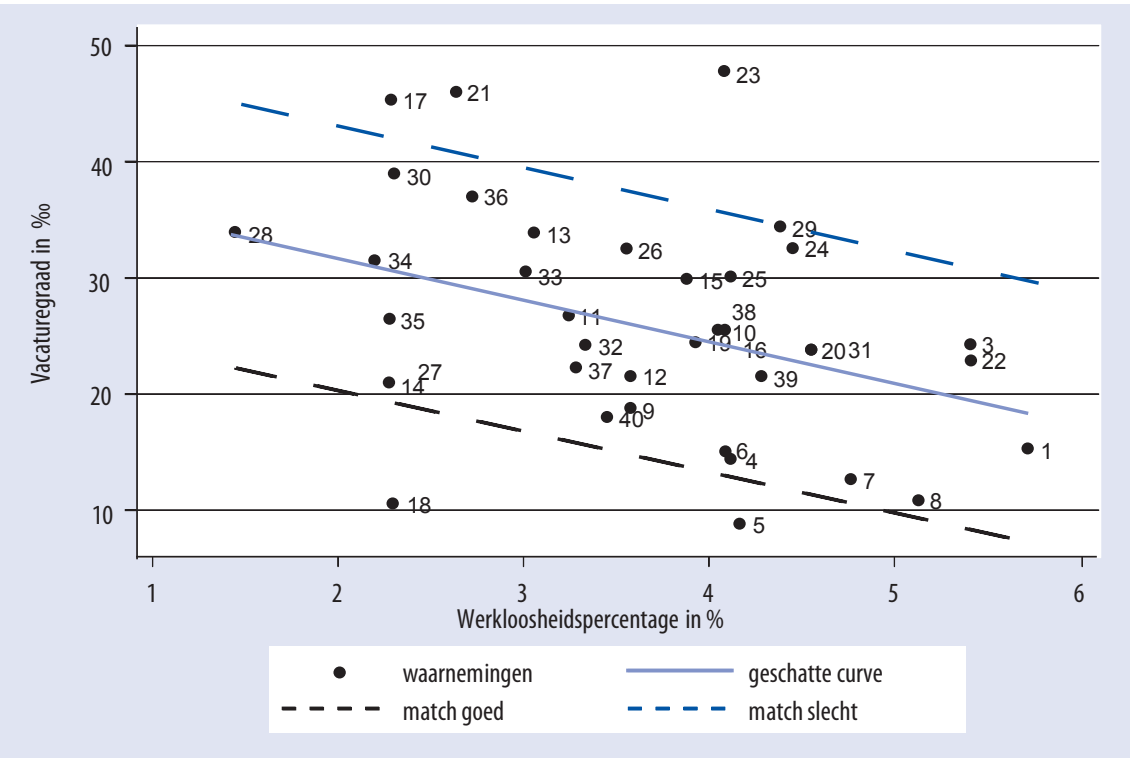

Bron: $\mathrm{CBS} / \mathrm{ROA}$

Ter aanvulling op het bovenstaande is gebruik gemaakt van gegevens over de aansluiting tussen opleiding en beroep van $\mathrm{MBO}$-gediplomeerden anderhalf jaar na het verlaten van hun opleiding. $\mathrm{Er}$ is in de ROA Schoolverlatersenquêtes gevraagd hoe zij de aansluiting ervaren tussen hun competenties en de taken die ze in hun baan uitvoeren. In de analyse is de waardering I of 2 als slechte/matige aansluiting getypeerd, en 3 of 4 als voldoende/goede aansluiting. ${ }^{26}$ Voor de verklaring van de aansluiting zoals die wordt ervaren door $\mathrm{MBO}$-schoolverlaters is een logistische regressieanalyse uitgevoerd. Verklarende variabelen zijn de arbeidsmarktsituatie in een regio, twee indicatoren die de samenwerking tussen verschillende partijen in de regio weergeven (waaronder ROC's en werkgevers), en enkele controlevariabelen op regionaal en individueel niveau. Het belangrijkste resultaat uit de logistische regressie-analyse is dat MBO-schoolverlaters in regio's met relatief weinig werklozen en/of veel vacatures over het algemeen een betere aansluiting tussen onderwijs en arbeidsmarkt ervaren. Een eenvoudige verklaring hiervoor is dat zij in hun regio schaarser zijn, en dus meer mogelijkheden hebben om een baan te kiezen die goed past bij hun

26. Zie voor een samenvatting van het onderzoek hoofdstuk 2 in L. van de Venne, F. Cörvers, M. Thomsen, B. Verlaan (20II), Regionale samenwerking. Een beleids-en onderzoeksagenda, ECBO, 's-Hertogenbosch/ Utrecht. 
opleidingsachtergrond. Dit is een interessante bevinding, die onder meer duidelijk makkt dat het voeren van regionaal-economisch beleid om de bedrijvigheid te stimuleren en het aantal vacatures te vergroten de kwalitatieve aansluiting zoals deze door MBO-schoolverlaters wordt ervaren, kan verbeteren. De indicatoren voor de samenwerking tussen verschillende regionale partijen (werkgevers, ROC's, overheden) bleken niet statistisch significant te zijn. ${ }^{27}$

\section{Verwachtingen voor arbeidsvraag en -aanbod op de middellange termijn}

Voor het voorliggende rapport is de macro-economische groei op de middellange termijn van belang. Daarvoor is gebruik gemaakt van de Actualisatie Economische Verkenning ${ }^{28}$ aangepast met de meer recente inzichten uit het Centraal Economisch Plan 20II (CEP 20II) en de zogenaamde juniraming ${ }^{29}$, alle van het CPB. In de Economische Verkenning (november 20IO) wordt voor de periode $20 \mathrm{II}-2 \mathrm{OI} 5$ bij een gemiddelde jaarlijkse economische groei van I,25\% uitgegaan van een jaarlijkse daling van $0,5 \%$ in arbeidsjaren van de werkgelegenheid in de marktsector. Voor de zorgsector wordt jaarlijks $2,75 \%$ werkgelegenheidsgroei verwacht en voor de overheid een werkgelegenheidskrimp van $2 \%$ per jaar. Per saldo leidt dit tot een krimp van $0,25 \%$ van de werkzame beroepsbevolking in Nederland. Ter aanvulling op deze middellangetermijnramingen zijn voor $201 \mathrm{I}$ en 2012 meer recente kortetermijnramingen van het $\mathrm{CPB}$ gebruikt. In het CEP $20 I I$ wordt bovendien een opsplitsing gegeven voor enkele sectoren..$^{30}$ In dit rapport wordt conform de juniraming van het $\mathrm{CPB}$ uitgegaan van een economische groei van 2 en $1,75 \%$ en een toename van het aantal werkzame personen van 0,75 en $\mathrm{I}, 25 \%$ in $201 \mathrm{I}$ respectievelijk $2012 .^{3 \mathrm{I}}$

Van belang is verder dat er in dit rapport in tegenstelling tot de voorgaande edities een prognosetermijn van zes jaar is aangehouden. Dat wil zeggen dat $201 \mathrm{I}$ het eerste en 2016 het laatste prognosejaar is. De prognoses in dit rapport zijn zoveel mogelijk weergegeven als gemiddeld jaarlijks percentage van de werkzame beroepsbevolking in 20IO. Daar waar toch aantallen personen of percentages over de hele prognoseperiode zijn weergegeven wordt dit uitdrukkelijk vermeld om verwarring met de gepresen-

27. De indicatoren voor regionale samenwerking werden echter op een naïeve wijze gemeten. Eén indicator voor samenwerking was het al dan niet bestaan van een RPA (Regionale Platform Arbeidsmarktbeleid) in een regio, of de opvolger daarvan. Als tweede indicator voor de samenwerking tussen ROC's en werkgevers werd gekeken naar het percentage MBO'ers per regio dat in een BBL-traject (beroepsbegeleidende leerweg, het vroegere leerlingwezen) is afgestudeerd. Bij een hoger percentage werd verondersteld dat er meer samenwerking is tussen onderwijsinstellingen en werkgevers in de regio.

28. CPB (20IO), Actualisatie Economische Verkenning 20II-20I5 (Verwerking Regeerakkoord), no. 213, november, Den Haag. De in dit rapport veronderstelde macro-economische ontwikkelingen voor 2016 zijn gelijk aan die voor de gemiddelde ontwikkelingen in 20II-20I5.

29. CPB (2OII), Centraal Economisch Plan 20II, april, Den Haag; CPB (20II), Juniraming 20II, CPB Policy Brief 20II/06, Den Haag.

30. De MEV 2012 bevat geen sectorale opsplitsing; de CEP $20 I I$ en de Economische Verkenning bevatten een beperkte opsplitsing. Voor verdere differentiatie van de sectorprognoses is gebruik gemaakt van verdeelmodellen van het EIM.

3I. Dit is wat positiever dan in de meer recente $M E V 20 I 2$. 
teerde gegevens in de eerdere edities te voorkomen. Mede op basis van de bovenstaande veronderstellingen komt de groei van de werkzame beroepsbevolking uit op gemiddeld jaarlijks $0,4 \%$ (in personen als percentage van het basisjaar 20IO). Dit betekent een groei van ruim 30.000 arbeidskrachten per jaar over de periode 20II-20I6. In tabel I.I worden voor de zesjaarsperiode tot 2016 en de historische vijfjaarsperiode tussen 2006 en 2010 zowel de werkgelegenheidsgroei als de arbeidsmarktuitstroom en -instroom weergegeven. Alle cijfers hebben betrekking op jaarlijkse groeipercentages ten opzichte van het basisjaar (respectievelijk 2005 en 20IO).

De som van de werkgelegenheidsgroei en de (netto) uitstroom is gelijk aan het totaal aan baanopeningen. Het gaat hierbij om de netto werkgelegenheidsgroei, dat wil zeggen dat in de komende periode de werkgelegenheid voor de meeste segmenten op de arbeidsmarkt groeit, maar voor sommige krimpt. De bruto werkgelegenheidsgroei heeft betrekking op alleen die segmenten waarop de werkgelegenheid groeit. De werkenden die op deze groeisegmenten erbij komen (i.e. positieve uitbreidingsvraag van gemiddeld jaarlijks $0,1 \%$ ) worden gerekend tot de baanopeningen van gemiddeld jaarlijks 4,I\% tot 20I6, zoals weergegeven in tabel I.I. De werkenden die hun baan zien verdwijnen (i.e. negatieve uitbreidingsvraag van gemiddeld -0,I\% per jaar) moeten uitstromen van de arbeidsmarkt, hetgeen kan leiden tot oplopende werkloosheid of dalende bruto participatiegraden (i.e. dalend arbeidsaanbod). Deze personen worden niet vervangen en derhalve niet meegerekend tot de vervangingsvraag. Het grootste deel van de arbeidsmarktuitstroom van gemiddeld 3,8\% tot 2016 wordt echter wel vervangen. De vervangingsvraag is gemiddeld jaarlijks 3,7\% van de werkgelegenheid in 2010 (zie tabel 2.4 in hoofdstuk 2). Een deel van de uitstroom en vervangingsvraag tot 2016 ontstaat overigens doordat personen van opleidingsachtergrond veranderen door het volgen van een niveauverhogende of richtingveranderende additionele opleiding naast hun werk. ${ }^{32}$

De relatief hoge werkgelegenheidsgroei tussen 2006 en 2010 is te verklaren door de grote werkgelegenheidstoename tot 2008 , waarna de crisis toesloeg. In 2008 is de werkzame beroepsbevolking gestegen tot ruim 7,4 miljoen personen. In 2010 is de werkzame beroepsbevolking ruim I00.000 kleiner dan in 2008, maar ruim 350.000 werkenden groter dan in 2005. Uiteraard speelt hier ook mee dat de omvang van de gemiddelde werkweek is gedaald omdat mensen in gemiddeld kleinere banen zijn gaan werken. Hetzelfde patroon kan ook worden vastgesteld als wordt gekeken naar arbeidsvolumes (totaal aantal uren verricht werk) of banen in plaats van naar de omvang van de werkzame beroepsbevolking.

32. Deze personen worden derhalve ook tot de arbeidsmarktinstroom van de nieuw behaalde opleiding gerekend. Dit betekent tevens dat de totale instroom van schoolverlaters op de arbeidsmarkt bestaat uit schoolverlaters en afgestudeerden die het initiële onderwijs hebben verlaten, maar ook uit werkenden die een postinitiële opleiding hebben behaald. Zie hierover ook paragraaf 2.5 van ROA (2003), De arbeidsmarkt naar opleiding en beroep tot 2008, ROA-R-2003/II, Universiteit Maastricht. 
Tabel 1.1

Arbeidsmarktontwikkeling 2006-2010 en de prognoses voor de periode 2011-2016, als gemiddeld jaarlijks percentage van de werkgelegenheid in het basisjaar

\begin{tabular}{lcc} 
& $2006-2010$ & $2011-2016$ \\
\hline Werkgelegenheidstoename & $\%$ & $\%$ \\
\hline Arbeidsmarktuitstroom & 1,2 & 0,4 \\
\hline Baanopeningen (arbeidsvraag) & 3,2 & 3,8 \\
Arbeidsmarktinstroom schoolverlaters (arbeidsaanbod) & 4,4 & 4,1 \\
Bron: ROA & 3,4 & 3,5
\end{tabular}

Het totaal aantal baanopeningen dat voor de komende periode wordt verwacht is lager dan het gerealiseerde aantal baanopeningen in de afgelopen periode. Dat komt met name door de terugval in de verwachte werkgelegenheidsgroei van gemiddeld jaarlijks I,2\% naar 0,4\%. Daarentegen zal de vervangingsvraag verder stijgen. Per saldo zal het gemiddeld jaarlijks percentage baanopeningen lager uitvallen, namelijk 4,I\% tegenover $4,4 \%$. Omdat ook de arbeidsmarktinstroom enigszins toeneemt lijkt de schaarste tot 2016 iets lager te worden dan in de periode van 2006 tot 20 Io het geval was.

De situatie op de verschillende segmenten van de Nederlandse arbeidsmarkt kan echter drastisch uiteenlopen. Daardoor zijn de discrepanties op deze segmenten (uiteenlopend van vraag- tot aanbodoverschotten) belangrijker dan de optelling over de segmenten zoals in tabel I.I is gebeurd. Doordat de verwachte knelpunten in de personeelsvoorziening voor werkgevers en de arbeidsmarktperspectieven voor schoolverlaters in dit rapport gedifferentieerd zijn naar beroep en opleiding wordt inzicht verkregen in de aard en de omvang van de discrepanties op de verschillende segmenten van de arbeidsmarkt (i.e. de kwalitatieve discrepanties op macroniveau). Met andere woorden, de kwantitatieve discrepanties kunnen dan wel enigszins afnemen voor de komende periode, voor de kwalitatieve discrepanties hoeft dit niet te gelden. Bij een toename van de kwalitatieve discrepanties verschuift de UV-curve in figuur I.I in noordoostelijke richting, waardoor er gelijktijdig meer werklozen én vacatures zijn. Vooral als de vacaturegraad voorlopig relatief laag blijft kan de werkloosheid weer verder oplopen zoals figuur I.I laat zien voor de periode tussen 200 I en 2005. De vacaturegraad steeg volgens het CBS (Statline) tussen het eerste kwartaal van 2010 en het tweede kwartaal van 20 II van I5 naar I8 vacatures per I.000 banen. In de kortetermijnprognoses van het CPB (MEV 20I2) is de werkloosheid in 2011 en 2012 iets lager dan in 20IO, hoewel de werkloosheid volgens het CBS in de tweede helft van $201 \mathrm{I}$ aan het stijgen is tot meer dan $5,5 \%$. Daarmee lijkt wel een begin gemaakt van de verschuiving van de UV-curve in noordoostelijke richting, met meer kwalitatieve discrepanties. 


\subsection{Werkgelegenheidsontwikkeling naar bedrijfssector}

De werkgelegenheidsontwikkeling van de verschillende sectoren weerspiegelt het conjuncturele verloop maar ook de beleidsmaatregelen van de regering. Met name de exportsectoren en de bouw hebben veel last gehad van de economische crisis die in 2008 begon. De conjuncturele ontwikkeling komt voor een aantal sectoren bovenop de structurele trend van verdienstelijking van de werkgelegenheid. De verdienstelijking van de werkgelegenheid is deels te verklaren doordat productiviteitsstijgingen in arbeidsintensieve dienstensectoren moeilijker te realiseren zijn dan in de agrarische en de kapitaalintensieve industriesectoren, inclusief de voor Nederland belangrijke agro- en voedingsindustrie. ${ }^{33}$

\section{Tabel 1.2}

Ontwikkeling van het aantal werkenden per bedrijfssector 2006-2010, en de uitbreidingsvraag naar bedrijfssector 2011-2016, gemiddelde jaarlijkse groei als percentage van het basisjaar

\begin{tabular}{lccc}
\hline Bedrifssector & $\begin{array}{c}\text { Aantal werkenden } \\
\text { gem. } 2009-2010\end{array}$ & $2006-2010$ & $2011-2016$ \\
\hline Landbouw en visserij & 185.000 & $\%$ & $-2,0$ \\
\hline Voeding & 125.000 & $-1,7$ & $-2,2$ \\
\hline Chemie & 95.000 & $-4,3$ & $-1,8$ \\
\hline Metaal en elektrotechniek & 290.000 & $-4,1$ & 2,3 \\
\hline Overige industrie & 299.500 & $-2,9$ & $-0,4$ \\
\hline Energie & 60.500 & 1,0 & $-3,6$ \\
\hline Bouw & 462.500 & $-1,6$ & 1,4 \\
\hline Onroerend goed & 66.500 & $-2,6$ & 0,7 \\
\hline Handel en reparatie & 905.500 & $-1,4$ & 3,2 \\
\hline Transport & 306.500 & $-1,5$ & 0,8 \\
\hline Communicatie & 112.000 & $-1,4$ & $-4,1$ \\
\hline Bank- en verzekeringswezen & 223.500 & $-2,9$ & $-0,3$ \\
\hline Horeca en zakelijke dienstverlening & 1.412 .500 & 0,9 & 0,7 \\
\hline Gezondheidszorg & 1.234 .500 & 3,3 & 2,5 \\
\hline Overheid en onderwijs & 1.049 .000 & 1,3 & $-2,7$ \\
\hline Totaal (incl. overig) & & & 0,4 \\
\hline Bron: ROA/CBS/CPB/EIM & 7.430 .000 & 1,2 & \\
\hline
\end{tabular}

Bron: $\mathrm{ROA} / \mathrm{CBS} / \mathrm{CPB} / \mathrm{EIM}$

In tabel $\mathrm{I} .2$ is voor elke sector het aantal werkenden weergegeven (gemiddelde 200920IO) naast de gerealiseerde werkgelegenheidsontwikkeling tussen 2005 en 20 Io en de verwachte werkgelegenheidsontwikkeling tot 20I6. In totaal waren er in Nederland ruim 7,4 miljoen mensen werkzaam voor I2 uur of meer per week. De meeste mensen zijn werkzaam in dienstensectoren zoals handel en reparatie, horeca en zakelijke dienstverlening, gezondheidszorg en overheid en onderwijs. Ondanks dat de werkgelegenheid tussen 2005 en 2010 met gemiddeld jaarlijks I,2\% groeide, is de werkgelegen-

33. Zie over productiviteitsstijgingen en de 'Wet van Baumol' kader Ir in CPB (2007), Centraal Economisch Plan 2007, april, Den Haag; SCP (200I), De sociale staat van Nederland 200I, Den Haag. 
heid in de meeste sectoren gekrompen. Alleen de relatief grote dienstsectoren horeca en zakelijke dienstverlening, gezondheidszorg en overheid en onderwijs hebben een aanzienlijke werkgelegenheidsstijging doorgemaakt. Ook de werkgelegenheid in de qua arbeidsvolume kleine energiesector is gegroeid. Alle overige sectoren zijn mede door de economische crisis aanzienlijk gedaald in werkgelegenheid. Voor sectoren als de landbouw en visserij en de voedingssector is er sprake van een structurele krimp van de werkgelegenheid. Ook voor de sectoren chemie en metaal en elektrotechniek heeft een sterke daling van de werkgelegenheid plaatsgevonden, die vooral samenhing met de economische crisis.

Voor de komende jaren komt er een divers beeld van de werkgelegenheidsontwikkeling in de verschillende sectoren naar voren. Dit heeft ermee te maken dat bedrijven in sommige sectoren al flink zijn afgeslankt door de crisis, waardoor het personeelsbestand tot een minimum is teruggebracht en weer ruimte voor groei is ontstaan. Dit lijkt met name voor de sectoren metaal en elektrotechniek, bouw, onroerend goed, handel en reparatie en transport het geval te zijn. Desondanks zullen de meeste van deze sectoren niet meer het werkgelegenheidsniveau van vijf tot tien jaar geleden meer halen. In andere sectoren zet een meer regelmatige en structurele afbouw van de werkgelegenheid zich voort. Dit lijkt met name het geval te zijn voor de landbouw en visserij, voeding, chemie en overige industrie. In de meeste van deze sectoren zal echter de werkgelegenheid minder hard afnemen dan gedurende de afgelopen vijf jaar.

In sectoren als energie, communicatie en bank- en verzekeringswezen lijken sectorspecifieke regulering en concurrentie een belangrijke rol te spelen bij de groei van bedrijven, waardoor een wat grillig beeld van de werkgelegenheidsontwikkeling lijkt te ontstaan dat niet altijd spoort met de macro-economische ontwikkelingen. Daarentegen blijft de werkgelegenheid binnen de sectoren horeca en zakelijke dienstverlening en gezondheidszorg stabiel toenemen. De verwachte werkgelegenheidskrimp van de overheid, in het bijzonder het openbaar bestuur, is een indirect gevolg van de financiële crisis in Europa. Het regeringsbeleid was er immers in eerste instantie juist op gericht om niet te bezuinigen zodat de economie niet nog verder zou afglijden. Inmiddels vereist de oplopende staatsschuld in combinatie met de afspraken binnen de Europese Unie om de Euromunt te ondersteunen dat er maatregelen worden genomen om de begrotingstekorten te reduceren en de staatsschuld af te bouwen. Daarnaast ligt er voor de sector onderwijs geen werkgelegenheidsgroei in het verschiet door de teruglopende leerlingenaantallen als gevolg van de ontgroening van de bevolking.

\subsection{Werkgelegenheidsontwikkeling naar beroepsklasse}

Recente ontwikkelingen laten zien dat schokken in de economie en werkgelegenheid die hun oorsprong vinden in een bepaalde sector van grote invloed zijn op de werkgelegenheid in andere sectoren, inclusief de beroepenstructuur in deze sectoren. 
Zo heeft de financiële crisis schokeffecten teweeg gebracht in onder meer de bank- en verzekeringswereld en de onroerendgoedsector, en na enige tijd ook de overheidssector. De gevolgen blijven niet beperkt tot de sectoren die oorspronkelijk geraakt zijn, maar kunnen andere sectoren op velerlei wijze 'besmetten'. Schokeffecten kunnen leiden tot intersectorale verschuivingen in de werkgelegenheid, welke op hun beurt in belangrijke mate de werkgelegenheidsontwikkelingen naar beroep bepalen. Daarnaast zijn de geschetste structurele en conjuncturele werkgelegenheidsontwikkelingen van bedrijfssectoren in de vorige paragraaf van groot belang voor de werkgelegenheidsontwikkeling van beroepen. De langetermijnontwikkelingen van de werkgelegenheid van bedrijfssectoren, zoals bijvoorbeeld de krimpende werkgelegenheid voor de agrarische sector en de voortgaande verdienstelijking van de werkgelegenheid, spelen een belangrijke rol voor de verwachte werkgelegenheidsontwikkeling van de beroepen die in deze sectoren worden uitgeoefend.

Een andere belangrijke factor voor de werkgelegenheidsontwikkeling van beroepen zijn de verschuivingen in de beroepenstructuur binnen bedrijfssectoren, i.e. intrasectorale verschuivingen. ${ }^{34}$ Deze verschuivingen in de beroepenstructuur binnen sectoren worden medebepaald door de investeringen in kapitaal en de mate van technologische vooruitgang. Vooral de werkgelegenheidstoename van de hogere en meer kennisintensieve beroepsgroepen kan voortkomen uit het gebruik van moderne productietechnieken en de daarmee samenhangende nieuwe organisatievormen. ${ }^{35}$ Deze veranderingen bepalen bovendien het innovatie- en concurrentievermogen van bedrijven. Bedrijven die te weinig investeren in nieuwe technologieën kunnen marktaandeel verliezen of op den duur zelfs verdwijnen, waardoor ook de werkgelegenheid in de lagere beroepen in deze bedrijven verdwijnt.

Tabel I.3 geeft een overzicht van de gerealiseerde werkgelegenheidsontwikkeling en de verwachte uitbreidingsvraag per beroepsklasse voor respectievelijk de periodes 20062010 en 20II-20I6. De ir beroepsklassen die in de tabel zijn opgenomen bevatten doorgaans beroepsgroepen van zowel hoger als lager en middelbaar beroepsniveau. ${ }^{36}$ Tussen 2006 en 2010 waren er slechts twee beroepsklassen met een afnemende werkgelegenheid. Dit waren de agrarische beroepen en de technische en industrieberoepen. Voor deze beroepsklassen spelen trends als de verdienstelijking van de werkgelegenheid en het gebruik van kapitaalintensievere en dus arbeidsbesparende productiemethoden een belangrijke rol. De werkgelegenheid groeide met gemiddeld meer dan $3 \%$ per jaar voor de pedagogische beroepen (docenten) en de sociaal-culturele beroepen (arbeidsbemiddelaars, personeelsfunctionarissen, onderzoekers).

34. Een analyse en uitsplitsing van inter- en intrasectorale ontwikkelingen wordt gegeven in F. Cörvers en J. Meriküll (2007), 'Occupational Structures across 25 EU Countries: The Importance of Industry Structure and Technology in Old and New EU Countries', Economic Change and Restructuring, Vol. 40, pp. 327-359.

35. F. Cörvers en A. Dupuy (2006), Explaining the Occupational Structure of Dutch Sectors of Industry, I9882003, ROA-W-2006/7E, Universiteit Maastricht.

36. Zie Bijlage B voor een beschrijving van de onderliggende beroepsgroepen per beroepsklasse. 
Verwacht wordt dat er tussen $201 \mathrm{I}$ en 2016 slechts twee beroepsklassen zijn waarvoor de werkgelegenheid nog toeneemt: de medische en paramedische beroepen, en de verzorgende en dienstverlenende beroepen. De laatste twee beroepsklassen groeien door de in verband met de vergrijzing structureel toenemende behoefte aan zorg in Nederland. De verzorgende en dienstverlenende beroepen komen echter ook voor in de commerciële dienstverlening, die veel conjunctuurgevoeliger is dan de gezondheidszorg.

De grootste afname van de werkgelegenheid wordt verwacht voor de creatieve beroepen (vooral de tolken, vertalers en schrijvers en de taalkundigen), de agrarische beroepen, en de pedagogische beroepen. Hoewel er veel creatieve beroepen voorkomen in de zakelijke dienstverlening, waarvoor nog groei wordt voorzien, zijn ook de overheid en de overige industrie belangrijke sectoren voor deze beroepen. In deze sectoren krimpt de werkgelegenheid naar verwachting de komende jaren. Voor de pedagogische beroepen is de werkgelegenheidsgroei eveneens negatief na jaren van grote groei. Dat komt doordat het aantal leerlingen in het primair onderwijs, voortgezet onderwijs en het middelbaar beroepsonderwijs afneemt of nauwelijks nog toeneemt. Alleen voor het hoger onderwijs wordt nog een flinke groei van het aantal studenten voorzien. ${ }^{37}$ Ten slotte is ook de afbouw van de werkgelegenheid in de sociaal-culturele en de informaticaberoepen opmerkelijk gezien de voorbije jaren van bovengemiddelde groei. Ook hier speelt de verwachte krimp van de overheidssector een rol.

\section{Tabel 1.3}

Ontwikkeling van het aantal werkenden per beroepsklasse 2006-2010 en de uitbreidingsvraag naar beroepsklasse 2011-2016, gemiddelde jaarlijkse groei als percentage van de werkgelegenheid in het basisjaar

\begin{tabular}{lccc}
\hline Beroepsklasse & $\begin{array}{c}\text { Aantal werkenden } \\
\text { gem. 2009-2010 }\end{array}$ & $\begin{array}{c}2006-2010 \\
\%\end{array}$ & $\begin{array}{c}2011-2016 \\
\%\end{array}$ \\
\hline Pedagogische beroepen & 412.500 & 3,2 & $-0,8$ \\
\hline Creatieve beroepen & 156.000 & 0,3 & $-1,4$ \\
\hline Agrarische beroepen & 223.000 & $-2,5$ & $-0,9$ \\
\hline Technische en industrieberoepen & 1.314 .500 & $-1,6$ & $-0,2$ \\
\hline Transportberoepen & 407.500 & 0,0 & $-0,2$ \\
\hline Medische en paramedische beroepen & 474.000 & 1,9 & 2,7 \\
\hline Economisch-administratieve beroepen & 2.120 .500 & 1,2 & $-0,2$ \\
\hline Informaticaberoepen & 278.000 & 1,5 & $-0,5$ \\
\hline Sociaal-culturele beroepen & 323.500 & 3,4 & $-0,2$ \\
\hline Verzorgende en dienstverlenende beroepen & 1.337 .000 & 2,1 & 2,2 \\
\hline Openbare orde- en veiligheidsberoepen & 119.500 & 0,2 & $-0,1$ \\
\hline Totaal (incl. overig) & & & 0,4 \\
Bron: ROA (AIS) & 7.430 .000 & 1,2 & \\
\hline
\end{tabular}

37. Ministerie van OCW (20II), Referentieraming 20II, Den Haag. 


\subsection{Werkgelegenheidsontwikkeling naar opleidingsniveau}

Over het algemeen worden er drie oorzaken gegeven voor de toename van de vraag naar hoger opgeleiden ten koste van lager opgeleiden. Ten eerste worden door de toepassing van nieuwe technologieën steeds meer hoger opgeleiden gevraagd. Ten tweede speelt mogelijk ook de toename van de kapitaalintensiteit een belangrijke rol in de stijgende vraag naar hoger opgeleiden. Het intensieve gebruik van nieuwe machines met geavanceerde toepassingen verhoogt de productiviteit, maar leidt ook tot een toenemende complexiteit van de uit te voeren taken. Daarnaast bewerkstelligen technologische ontwikkelingen vaak ook organisatorische veranderingen, zoals het streven naar een plattere organisatiestructuur, decentralisering en 'empowerment', die op hun beurt de kwalificatie-eisen verder doen stijgen. Ten derde wordt ook de toename van het internationale handelsverkeer wel genoemd als factor die leidt tot een specialisatie in de productie van kennisintensieve goederen en diensten. Bovengenoemde factoren hangen samen met verschuivingen in de werkgelegenheid tussen en binnen verschillende bedrijfssectoren en beroepsklassen.

Bij de arbeidsmarktprognoses voor de uitbreidingsvraag in dit rapport wordt er rekening gehouden met de zogenaamde 'upgrading' van vaardigheden. Deze heeft betrekking op de steeds hogere kwalificatievereisten die werkgevers stellen binnen de beroepen en functies in hun bedrijven en instellingen. De snelheid waarmee vaardigheden upgraden wordt gemeten als de procentuele verandering van de vraag naar hooggeschoolden in vergelijking met die van laaggeschoolden. In deze paragraaf wordt weergegeven hoe de upgradingssnelheid in de Nederlandse sectoren zich verhoudt tot dezelfde sectoren in andere landen. ${ }^{38}$ Hoewel hiervoor gebruik is gemaakt van een andere methodiek en andere data dan voor de berekening van de uitbreidingsvraag in dit rapport, geeft dit wel een goed beeld van hoe de ontwikkelingen in de arbeidsvraag in Nederland zich voltrekken ten opzichte van andere landen.

De upgradingssnelheid in deze paragraaf is gemeten op basis van de EU-Klems data over de periode 1970-2005. Er is een aparte productiefunctie geschat voor elke sector en elk land op basis van de prijzen en de volumes van vijf verschillende productiefactoren. Er worden twee soorten kapitaal (IT en niet-IT) en drie soorten arbeid onderscheiden, lager opgeleiden, middelbaar opgeleiden en hoger opgeleiden. Elke productiefactor heeft een specifieke efficiency parameter met een trend in de tijd. De omvang van deze trend geeft aan wat de extra vraag is naar de respectievelijke soort arbeid als gevolg van de ontwikkelingen in de productietechniek.

Tabel I.4 geeft de upgradingssnelheid weer voor II sectoren in I2 landen. Zoals verwacht is de relatieve vraag naar hooggeschoolden toegenomen in de meeste sectoren en landen. Daarentegen heeft de Verenigde Staten de meeste sectoren met een negatieve upgrading, i.e. 'downgrading'.

38. A. Dupuy and J. Sauermann (te verschijnen), Skills upgrading, CEDEFOP-project on 'Forecasting skill supply and demand in Europe', Technical Report. 


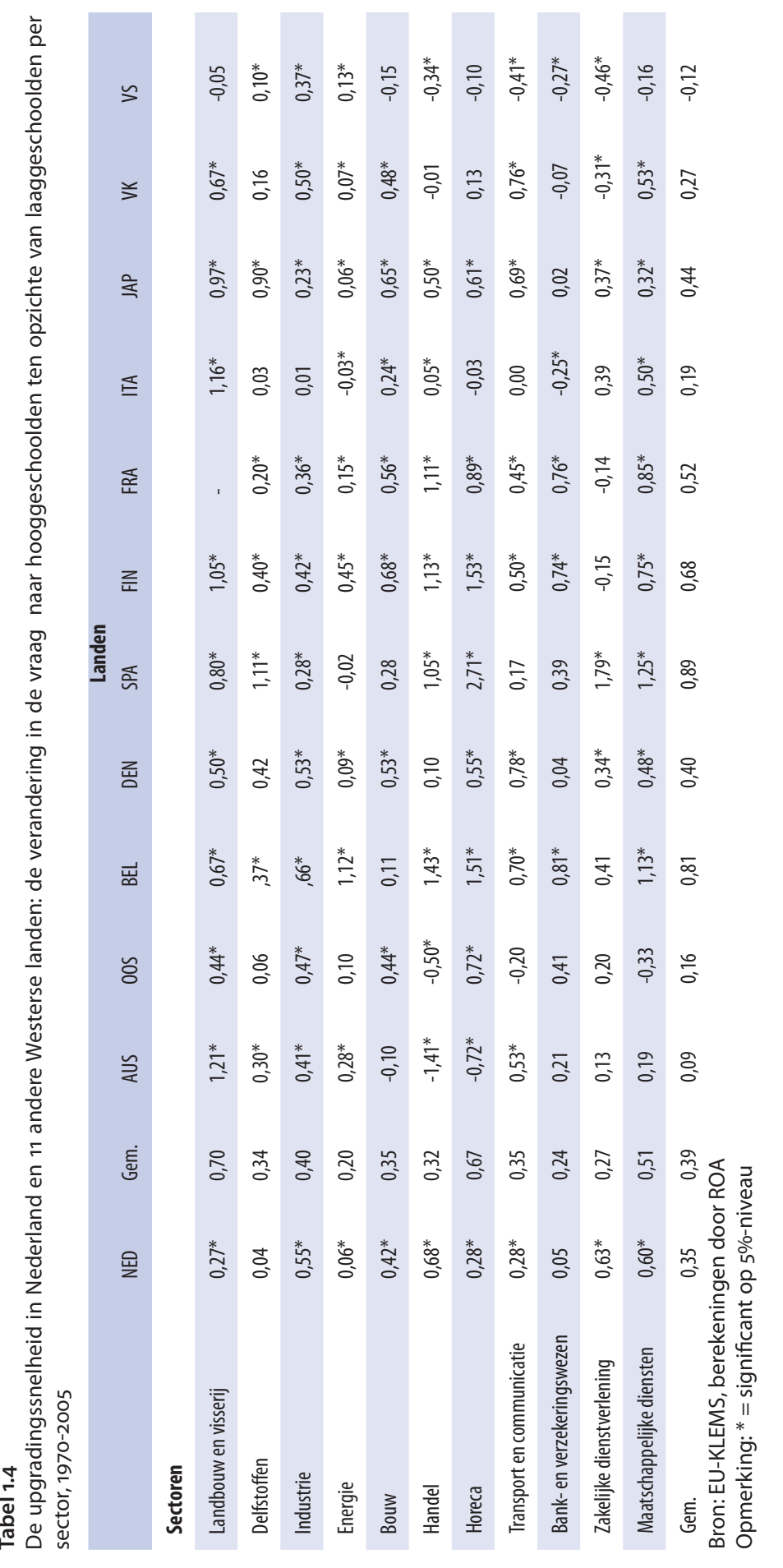


Het is opvallend dat er grote variaties zijn in de grootte van de verandering tussen de landen en sectoren. De tabel laat zien dat de upgradingssnelheid in de industrie tamelijk homogeen is in de verschillende landen en ligt tussen de 0,0I\% in Italië en $0,66 \%$ in België. Dat betekent dat de vraag naar hooggeschoolden in vergelijking met die van laaggeschoolden toeneemt met $0,66 \%$ per jaar in België, terwijl de relatieve vraag vrijwel constant blijft in Italië. Daarentegen varieert de upgradingssnelheid in de handel van -I,4I\% in Australië tot I,43\% in België. In vergelijking tot andere landen vertoont Nederland een vrij lage upgradingssnelheid in landbouw en visserij, delfstoffenwinning, energie, horeca en in het bank- en verzekeringswezen. In de sectoren handel en zakelijke dienstverlening is de upgradingssnelheid in Nederland vrij hoog, en in de andere sectoren gemiddeld.

Verschillen tussen de sectoren binnen de landen kunnen gemakkelijk worden verklaard doordat elke sector een specifiek type technologie kiest die een andere mix van geschoolde en ongeschoolde arbeid vereist. Verschillen tussen de landen voor eenzelfde industrie zouden kunnen worden verklaard doordat verschillende jaargangen van productietechnieken worden gebruikt in verschillende landen. Een andere mogelijkheid voor de verklaring van afwijkingen tussen dezelfde sectoren van verschillende landen zou kunnen zijn dat landen verschillende instituties hebben ${ }^{39}$, waardoor investeringsbeslissingen in technologieën per land anders uitvallen. Ook kunnen bedrijven en instellingen in elk land geconfronteerd worden met verschillende wettelijke beperkingen op sectoraal niveau (sectorspecifieke regelgeving), waardoor de bedrijven aan de 'technology frontier' in dezelfde sectoren van verschillende landen investeren in andere technologieën..$^{\circ}$

In de arbeidsmarktprognoses in dit rapport wordt rekening gehouden met de bovengenoemde upgrading van kwalificatievereisten, maar dat gebeurt wel met een andere methodiek dan die is gebruikt voor de schattingen in de hierboven gepresenteerde tabel, omdat classificaties en beschikbare databronnen van elkaar verschillen. ${ }^{4 \mathrm{I}}$ Het opleidingseffect in dit rapport wijst op de veranderingen in de gevraagde opleidingsachtergronden binnen beroepen..$^{42}$ Dit effect geeft de mate van upgrading binnen beroepen weer. De upgrading van de kwalificatievereisten is een gevolg van de aanpassingen in de samenstelling van het personeelsbestand binnen bedrijven en instellingen aan het gebruik van nieuwe technologieën en productiemethoden. Ook een kapitaalintensievere productie, organisatorische veranderingen zoals plattere organisaties en wereldwijde specialisatie kunnen leiden tot een grotere vraag naar vakbekwame en/

39. Er kan worden gerefereerd aan verschillen in loonongelijkheid als gevolg van bijvoorbeeld minimumlonen of de onderhandelingsmacht van vakbonden. Zie D. Acemoglu (2003), 'Cross-Country Inequality Trends', Economic Journal, Vol. II3, pp. Fi2I-FI49.

40. Denk aan bijvoorbeeld de regelgeving in telecommunicatie, stamceltherapie, genetische manipulatie van gewassen, etc.

4I. De upgradingssnelheid is berekend op basis van de methode in A. Dupuy (2006), Measuring Skillupgrading in the Dutch Labor Market, ROA-W-2006/3E, Universiteit Maastricht.

42. In de methodiek bij tabel I.4 is gekeken naar veranderingen in het opleidingsniveau binnen sectoren, waarbij de tussenstap via beroepen is overgeslagen. 
of hoger opgeleide medewerkers. Daarnaast wordt er bij de uitbreidingsvraag naar opleiding rekening gehouden met het beroepseffect, dat de verschuivingen in de beroepenstructuur binnen bedrijfssectoren weergeeft. In paragraaf I.3 is gewezen op de mogelijke invloed van de intrasectorale verschuivingen in de beroepenstructuur als gevolg van investeringen in nieuwe productietechnieken en organisatorische vernieuwingen, waardoor de hogere beroepen vaak relatief sneller dan gemiddeld groeien. Het bedrijfssectoreffect geeft de verschillen ten gevolge van de werkgelegenheidsontwikkeling van bedrijfssectoren weer.

Tot slot wordt er bij het opstellen van de arbeidsmarktprognoses voor de uitbreidingsvraag en het berekenen van de arbeidsmarktdiscrepanties rekening gehouden met het substitutie-effect. Dit refereert naar de additionele vraag (in positieve of negatieve zin) door aanbodtekorten of aanbodoverschotten bij vanuit arbeidsmarktoogpunt verwante opleidingen. Dit effect geeft de verdringing van opleidingen weer door opleidingen van een hoger niveau met aanbodoverschotten, of omgekeerd de aanzuigende werking die uitgaat van een tekortschietend aanbod op mensen met een verwante opleidingsachtergrond. De eerste drie effecten bepalen de uitbreidingsvraag, terwijl het substitutie-effect optreedt door de confrontatie tussen vraag en aanbod. De modellering van het substitutie-effect ${ }^{43}$ zorgt ervoor dat grote tekorten of overschotten binnen een bepaald opleidingstype zich kunnen verspreiden naar verwante opleidingstypen. Deze discrepanties op bepaalde arbeidsmarktsegmenten kunnen zich dus als een olievlek verspreiden over de hele arbeidsmarkt.

Tabel 1.5

Ontwikkeling van het aantal werkenden per opleidingsniveau 2006-2010 en de uitbreidingsvraag naar opleidingsniveau 2011-2016, gemiddelde jaarlijkse percentages

\begin{tabular}{lccc} 
Opleidingsniveau & $\begin{array}{c}\text { Aantal werkenden } \\
\text { gem. } 2009-2010\end{array}$ & $\begin{array}{c}2006-2010 \\
\%\end{array}$ & $\begin{array}{c}2011-2016 \\
\text { Basisonderwijs }\end{array}$ \\
\hline VMBO & 342.500 & $-0,1$ & 0,3 \\
\hline HAV0/VWO & 1.313 .500 & $-0,6$ & 0,2 \\
\hline MBO & 607.500 & $-0,6$ & 0,4 \\
\hline HBO & 2.545 .500 & 0,7 & 0,6 \\
\hline W0 & 1.661 .000 & 3,5 & 0,3 \\
\hline Totaal (incl. overig) & 800.500 & 2,1 & 0,6 \\
\hline BrOn: ROA (AIS) & & 1,2 & 0,4
\end{tabular}

Bron: ROA (AIS)

In tabel I.5 wordt de gerealiseerde werkgelegenheidsgroei en de verwachte uitbreidingsvraag naar opleidingsniveau weergegeven. De gemiddelde jaarlijkse uitbreidingsvraag in 20II-20I6 komt overeen met de som van het de eerder genoemde bedrijfssector-, beroeps- en opleidingseffecten. Uit tabel I.5 blijkt dat de uitbreidingsvraag op alle opleidingsniveaus positief is. In de voorbije periode was de werkgelegenheidsontwik-

43. F. Cörvers en H. Heijke (2004), Forecasting the labour market by occupation and education: Some key issues, ROA-W-2004/4, Universiteit Maastricht. 
keling negatief voor de ongeschoolden en de werkenden met een VMBO- en HAVO/ VWO-opleiding. Verschuivingen in de sector- en beroepensamenstelling in combinatie met het proces van upgrading hebben er dus in de afgelopen jaren toe geleid dat de werkgelegenheid voor lager geschoolden en algemeen middelbaar opgeleiden (i.e. zonder beroepsgerichte scholing) is afgenomen. De werkgelegenheid op HBOen WO-niveau groeide daarentegen fors, op MBO-niveau is de werkgelegenheidsgroei iets lager dan de gemiddelde jaarlijkse groei. Voor de komende periode wordt verwacht dat de uitbreidingsvraag op $\mathrm{MBO}$ - en WO-niveau hoger is dan gemiddeld, en voor de lagere niveaus en HBO-niveau lager dan gemiddeld. De verschillen in de verwachte uitbreidingsvraag zijn echter klein vergeleken met de werkgelegenheidsontwikkeling in de afgelopen vijf jaar.

\subsection{Toekomstige arbeidsmarktperspectieven naar opleidingsniveau}

In deze paragraaf worden per opleidingsniveau de som van de verschillende vraag- en aanbodcomponenten op de arbeidsmarkt met elkaar geconfronteerd. ${ }^{44}$ Als de werkgelegenheid toeneemt vormen de uitbreidingsvraag en de vervangingsvraag tezamen de baanopeningen voor nieuwe instromers op de arbeidsmarkt. De vervangingsvraag ontstaat bijvoorbeeld door pensionering, arbeidsongeschiktheid, en tijdelijke terugtrede van de arbeidsmarkt. Bij de vervangingsvraag naar opleiding is behalve de uittrede van de arbeidsmarkt ook het doorleren van werkenden van belang. Een werkende stroomt door het afronden van een vervolgopleiding in feite uit naar een ander opleidingstype. In dat geval ontstaat er vervangingsvraag bij het opleidingstype waartoe de vooropleiding van deze werkende wordt gerekend. ${ }^{45} \mathrm{Als}$ de werkgelegenheid krimpt zal een deel van het personeel dat uitstroomt bij bedrijven en instellingen niet vervangen worden. De vervangingsvraag bestaat dan alleen uit dat deel van het personeel dat uitstroomt en wel vervangen wordt. Bij krimpende werkgelegenheid kan er alleen sprake zijn van baanopeningen uit hoofde van vervangingsvraag.

Indien de verwachte baanopeningen en additionele substitutievraag per opleidingstype worden geconfronteerd met de arbeidsmarktinstroom van schoolverlaters en de potentiële arbeidsmarktinstroom van kortdurig werklozen, kan een indicatie worden gegeven van de toekomstige arbeidsmarktperspectieven per opleidingstype. Tabel I.6 geeft een overzicht van de verwachte vraag-aanbod stromen tot 20I6, waarbij uitbreidingsvraag, vervangingsvraag en arbeidsmarktinstroom zijn gepercenteerd op de omvang van de werkzame beroepsbevolking voor het betreffende opleidingsniveau in 20Io. In de tabel zijn de resultaten voor de uitbreidingsvraag, vervangingsvraag,

44. Zie 'Doel en opzet van de arbeidsmarktprognoses' aan het begin van dit rapport voor uitleg over het totale arbeidsmarktmodel.

45. Bovendien is er een belangrijk verschil tussen de vervangingsvraag per beroepsgroep en per opleidingstype. De beroepsmobiliteit is namelijk wel van invloed op de vervangingsvraag per beroepsgroep, maar heeft geen effect op de vervangingsvraag per opleidingstype. Het veranderen van beroep heeft immers geen gevolgen voor de opleidingsstructuur van de werkgelegenheid. De vervangingsvraag naar beroepsgroep komt in hoofdstuk 2 uitgebreid aan de orde. 
substitutievraag en arbeidsmarktinstroom van de IO2 onderliggende opleidingstypen (zie Bijlage B) geaggregeerd tot de zes opleidingsniveaus (met VMBO tl apart van $\mathrm{VMBO}$ ). Van belang is voorts op te merken dat VMBO-niveau in deze rapportage betrekking heeft op al degenen die een $\mathrm{VMBO}$-opleiding of een $\mathrm{MBO}$-opleiding op niveau I (assistent beroepsbeoefenaar/medewerker) hebben afgesloten. ${ }^{4}{ }^{6}$

Tabel 1.6

Uitbreidingsvraag, vervangingsvraag en arbeidsmarktinstroom, gemiddeld jaarlijks als percentage van de werkgelegenheid in 2010, en de daaruit volgende toekomstige arbeidsmarktperspectieven per opleidingsniveau, 2011-2016

\begin{tabular}{|c|c|c|c|c|c|}
\hline Opleidingsniveau & $\begin{array}{l}\text { Uitbreidings- } \\
\text { vraag } \\
\%\end{array}$ & $\begin{array}{c}\text { Vervangings- } \\
\text { vraag } \\
\%\end{array}$ & $\begin{array}{c}\text { Instroom } \\
\%\end{array}$ & ITA & $\begin{array}{l}\text { Typering } \\
\text { ITA }\end{array}$ \\
\hline Basisonderwijs & 0,3 & 4,2 & 6,3 & 1,14 & matig \\
\hline VMBO & 0,2 & 4,2 & 2,8 & 0,94 & goed \\
\hline VMBO tl & 0,1 & 5,1 & 1,8 & 0,88 & goed \\
\hline HAVO/VWO & 0,4 & 4,0 & 4,6 & 1,06 & matig \\
\hline MBO & 0,6 & 3,6 & 3,9 & 1,01 & redelijk \\
\hline HBO & 0,3 & 3,3 & 3,1 & 0,99 & goed \\
\hline Wo & 0,6 & 3,4 & 3,5 & 0,99 & goed \\
\hline Totaal (incl. overig) & 0,4 & 3,7 & 3,5 & 1,00 & goed \\
\hline
\end{tabular}

Bron: ROA (AIS)

Uit de tabel blijkt dat de verwachte jaarlijkse gemiddelde vervangingsvraag 3,7\% is voor de periode tot 2016 , wat veel groter is dan de uitbreidingsvraag en slechts iets meer dan de arbeidsmarktinstroom van gemiddeld 3,5\%. Vooral op de lagere niveaus is de vervangingsvraag hoog. Op VMBO-niveau is er weinig arbeidsmarktinstroom omdat de meeste jongeren doorleren op het MBO. Daarnaast neemt het aantal voortijdig schoolverlaters van het $\mathrm{MBO}$ gedurende de laatste jaren af, en zijn er steeds minder jongeren die een VMBO-opleiding volgen. ${ }^{47}$ De VMBO'ers die wel gaan werken combineren vakk werken en leren in de beroepsbegeleidende leerweg van het $\mathrm{MBO}$, waardoor bij het behalen van het $\mathrm{MBO}$-diploma vervangingsvraag ontstaat naar VMBO'ers. Dit kan zich manifesteren in de vraag naar leerlingen in BBL-trajecten (beroepsbegeleidende leerweg) bij bedrijven en instellingen.

Voor ongeschoolden en HAVO/VWO' ers bestaat dit zogenaamde 'doorleereffect' ook. Bij ongeschoolden gaat het om 'drop-outs' van het VMBO die na verloop van tijd toch proberen een opleiding te halen, in eerste instantie op VMBO-niveau. Dit gaat vaak in combinatie met werk omdat het volgen van een voltijdse opleiding voor velen niet

46. De drie hogere MBO-niveaus leiden op tot een zogenaamde startkwalificatie voor de arbeidsmarkt: basisberoepsbeoefenaar/medewerker (niveau 2), zelfstandig beroepsbeoefenaar/medewerker (niveau 3), gespecialiseerd beroepsbeoefenaar/ middenkaderfunctionaris (niveau 4). Hoe hoger het niveau, hoe hoger de moeilijkheidsgraad en hoe langer de opleiding duurt (van ongeveer I jaar op niveau I tot 4 jaar op niveau 4).

47. Ministerie van OCW (20II), Referentieraming 20II, Den Haag. 
mogelijk is. De groep bestaat deels uit jongeren met persoonlijke problemen, zoals gedragsmoeilijkheden, gezondheidsklachten of een handicap, en deels uit jongeren die op een later tijdstip alsnog een VMBO- of MBO-opleiding (vaak op niveau I) afronden..$^{4}$ Bij HAVO/VWO'ers gaat het om studenten die niet meteen beginnen met een hogere opleiding maar eerst gaan werken, of na enige maanden stoppen met de opleiding en gaan werken. Op beide niveaus ontstaat er vervangingsvraag als de VMBO-opleiding wordt afgesloten, of als men uittreedt van de arbeidsmarkt om een $\mathrm{HBO}$ - of WO-opleiding te gaan volgen.

Door de confrontatie tussen vraag en aanbod op de arbeidsmarkt wordt er inzicht verkregen in het arbeidsmarktperspectief voor schoolverlaters. De omvang van het arbeidsaanbod ten opzichte van de arbeidsvraag wordt weergegeven met de Indicator Toekomstig Arbeidsmarktperspectief (ITA). De ITA geeft de ex ante spanning tussen vraag en aanbod van schoolverlaters aan op basis van de verwachte ontwikkelingen van de uitbreidingsvraag, de vervangingsvraag en de instroom. Een ITA groter dan I,OO duidt op een $e x$ ante aanbodoverschot en dus een minder gunstig arbeidsmarktperspectief. Hoe groter de ITA, hoe groter het arbeidsaanbod ten opzichte van de -vraag, en hoe slechter derhalve het arbeidsmarktperspectief van schoolverlaters. Naarmate de ITA daalt wordt het perspectief beter.

Uit de tabel blijkt dat de arbeidsmarktperspectieven voor de schoolverlaters over het algemeen redelijk of goed zijn met uitzondering van schoolverlaters die slechts het basisonderwijs of HAVO/VWO doorlopen hebben. Indien ongeschoolden met alleen basisonderwijs geen vervolgopleiding afmaken bestaat voor hen een grote kans op inactiviteit. Zo was in de periode 2002-2005 bijna 20\% van de instromers in een arbeidsongeschiktheidsuitkering (WAO, Wajong, WAZ) ongeschoold.49 Voor HAVO/ VWO'ers zijn de arbeidsmarktperspectieven matig, vooral door de hoge instroom op de arbeidsmarkt. Voor MBO'ers lijkt de arbeidsmarkt wat meer in evenwicht te zijn. De uitbreidings- en vervangingsvraag zijn dan ook niet veel groter dan de arbeidsmarktinstroom. De ITA laat zien dat de arbeidsmarktperspectieven van HBO'ers en WO'ers gemiddeld genomen goed zijn.

Voor VMBO-schoolverlaters zijn de perspectieven goed door de hoge vervangingsvraag ten opzichte van de arbeidsmarktinstroom. Hier speelt het eerder genoemde 'doorleereffect' een rol. De goede arbeidsmarktperspectieven zijn mede een gevolg van het geringere aanbod van jongeren door de ontgroening van de bevolking en het grote aandeel jongeren dat vroeger of later besluit door te leren. Verder speelt een rol dat er de komende jaren een groeiende vraag is naar zorg en verzorging die deels wordt vervuld door degenen met een lage opleiding (VMBO of MBO niveau I). Het goede arbeidsmarktperspectief van VMBO'ers dient echter niet verward te worden met hun

48. ROA (2009), Zonder diploma, Aanleiding, Kansen en Toekomstintenties, ROA-R-2009/I, Universiteit Maastricht.

49. F. Cörvers (2009), 'De arbeidsmarktperspectieven voor arbeidsongeschikten: Het belang van opleiding', Maandblad Reïntegratie, Vol. 9, No. 3, pp. 9-II. 
loonbaanperspectief, dat zonder bijscholing slecht is wat betreft arbeidsvoorwaarden. Zonder bijscholing lopen zij na enige tijd de kans door werkgevers relatief duur bevonden te worden in vergelijking met nieuwe lichtingen van jongere VMBO'ers. Dit gebeurt als hun beloning stijgt met de leeftijd zonder dat daar een hogere productiviteit tegenover staat. VMBO'ers keren dan ook verderop in hun loopbaan vaker dan MBO'ers de arbeidsmarkt de rug toe, onder andere vanwege de slechtere beloning en secundaire arbeidsvoorwaarden, en de minder goede arbeidsomstandigheden en carrièrevooruitzichten. Mede daardoor participeert een derde van de VMBO'ers die deel uitmaken van de potentiële beroepsbevolking niet op de arbeidsmarkt, tegenover ongeveer een kwart van degenen met een diploma HAVO/VWO. ${ }^{50}$

Tabel I.7 geeft op elk opleidingsniveau aan hoeveel procent van de schoolverlaters die op de arbeidsmarkt instromen tot 2016 goede tot zeer goede vooruitzichten heeft. Bovendien wordt er een vergelijking gemaakt met de middellangetermijnperspectieven van schoolverlaters die twee jaar geleden zijn samengesteld. Opmerkelijk is dat de arbeidsmarktperspectieven in vergelijking met twee jaar geleden iets verslechteren, vooral door het wat verminderde arbeidsmarktperspectief voor HAVO/VWO en $\mathrm{HBO}$.

VMBO-schoolverlaters hebben over het algemeen goede vooruitzichten op werk. Hierbij dienen echter de eerder genoemde kanttekeningen in acht te worden genomen. De banen die voor hen beschikbaar zijn hebben meestal betrekking op leer-werkbanen (BBL-trajecten) of juist banen met een tijdelijke karakter en slechte arbeidsvoorwaarden en loopbaanperspectieven. De mogelijkheden voor een dergelijke baan zijn het grootst in de technische en verzorgende richtingen.

Voor de grote groep MBO'ers die de komende jaren instroomt op de arbeidsmarkt verbetert het perspectief enigszins ten opzichte van de vorige prognoses. $36 \%$ van de MBO'ers die de komende zes jaar op de arbeidsmarkt instromen heeft goede tot zeer goede vooruitzichten, vooral in de verpleging en de verzorging, en enkele grote technische opleidingen in de richtingen bouw, grond-, weg- en waterbouw en elektrotechniek.

Op HBO- en WO-niveau zijn de arbeidsmarktperspectieven het gunstigst voor opleidingen gericht op het onderwijs (hoge vervangingsvraag) en de zorg (hoge uitbreidingsvraag). Ook enkele technische en economische opleidingen op HBO-niveau laten goede vooruitzichten op de middellange termijn zien, hoewel minder goed dan twee jaar geleden. Op WO-niveau zijn de perspectieven duidelijk verbeterd ten opzichte van twee jaar geleden. Dit komt vooral doordat de verwachte vervangingsvraag nu ook voor de WO'ers aanzienlijk is toegenomen (zie hoofdstuk 2). Deze trend was twee jaar geleden alleen nog voor de HBO'ers te zien. Over het algemeen

50. Zie paragraaf 4.2 in ROA (200I), De arbeidsmarkt naar opleiding en beroep tot 2006, ROA-R-20oI/8, Universiteit Maastricht en hoofdstuk 4 in ROA (2005), De arbeidsmarkt naar opleiding en beroep tot 2010, ROA-R-2005/9, Universiteit Maastricht. 
zijn de perspectieven in de medische opleidingen goed door een hoge uitbreidings- en vervangingsvraag, en in enkele grotere bètatechnische opleidingen door een combinatie van een hoge vervangingsvraag en een lage arbeidsmarktinstroom.

Tabel 1.7

Percentage schoolverlaters waarvoor een goed tot zeer goed arbeidsmarktperspectief wordt verwacht per opleidingsniveau, 2009-2013 en 2011-2016

\begin{tabular}{lcc|} 
Opleidingsniveau & $2009-2013$ & $2011-2016$ \\
\hline Basisonderwijs & $\%$ & $\%$ \\
\hline VMBO & 0 & 60 \\
\hline HAV0/VWO & 56 & 0 \\
\hline MBO & 100 & 36 \\
\hline HBO & 28 & 40 \\
\hline WO & 56 & 40 \\
\hline Totaal (incl. overig) & 15 & \\
\hline Bron: ROA (AIS) & & 33 \\
\hline
\end{tabular}

Bron: ROA (AIS)

\subsection{Conclusies}

De ontwikkelingen op de arbeidsmarkt zijn de komende jaren hoogst onzeker. Het is op dit moment vooral onduidelijk of de werkloosheid blijft toenemen en met hoeveel. Daarnaast zijn er ook regionale verschillen. In het Westen van het land is de arbeidsmarktkrapte groter dan in de rest van het land, in het Noorden is de krapte juist minder groot. De verschillen tussen de arbeidsmarktsituatie in regio's nemen toe naarmate het opleidings- en baanniveau lager is. De geografische mobiliteit (verhuizing en pendel) van hoger opgeleiden zorgt er immers voor dat hoger opgeleide werklozen gemakkelijker een baan vinden in andere delen van het land als waarin ze woonachtig zijn. Voor middelbaar opgeleiden blijken vooral enkele stedelijke gebieden significant grotere discrepanties tussen werkzoekenden en vacatures te kennen dan sommige landelijke gebieden. MBO-schoolverlaters blijken anderhalf jaar na het verlaten van het onderwijs meer tevreden te zijn met de aansluiting tussen de door hen gevolgde opleiding en de functie-uitoefening in hun beroep als zij een ruimere keuze aan vacatures in de regio hebben. Niet onderzocht is hier hoe de werkgevers de aansluiting ervaren van het personeel dat zij aanstellen en hun functie-uitoefening.

Voor de komende jaren zal het verschil tussen vraag en aanbod op de arbeidsmarkt als geheel weliswaar afnemen, i.e. minder kwantitatieve discrepanties, maar zullen zich naar verwachting wel discrepanties op verschillende arbeidsmarktsegmenten voordoen. Het gaat daarbij om tekorten en overschotten die gelijktijdig op de verschillende segmenten bestaan. De discrepanties ontstaan vooral door de grote vervangingsvraag van gemiddeld jaarlijks 3,7\% van de werkgelegenheid. De uitbreidingsvraag zal naar verwachting slechts $0,4 \%$ gemiddeld per jaar bedragen. De conjunctuur drukt 
een zware stempel op de werkgelegenheidsontwikkeling naar bedrijfssector tot 2016 . Sommige sectoren zijn de afgelopen jaren al flink afgeslankt door de crisis, waardoor het personeelsbestand tot een minimum is teruggebracht en weer ruimte voor groei is ontstaan. Dit geldt vooral voor de sectoren metaal en elektrotechniek, bouw, onroerend goed, handel en reparatie en transport. Deze sectoren zullen echter meestal niet meer het werkgelegenheidsniveau van vijf tot tien jaar geleden halen. In andere sectoren zet een meer regelmatige en structurele afbouw van de werkgelegenheid zich voort, hoewel iets minder dan voorheen. Dit lijkt met name het geval te zijn voor de landbouw en visserij, voeding, chemie en overige industrie. De werkgelegenheid binnen de sectoren horeca en zakelijke dienstverlening en vooral de gezondheidszorg blijft stabiel toenemen. In de sector overheid en onderwijs krimpt de werkgelegenheid naar verwachting, door de bezuinigingen op het ambtenarenkorps in het openbaar bestuur en de dalende leerlingenaantallen in het onderwijs. Opvallend is verder dat de werkgelegenheid zal dalen in alle beroepsklassen, met uitzondering van de medische en paramedische beroepen en de verzorgende en dienstverlenende beroepen. Vooral lager opgeleiden in de verzorgende beroepen hebben daar voordeel bij.

Evenals in andere landen is ook in Nederland een structurele trend van de upgrading van kwalificatievereisten zichtbaar. De upgradingssnelheid in de verschillende sectoren in Nederland is over het algemeen gemiddeld, maar in de sectoren handel en zakelijke dienstverlening is de upgradingssnelheid vrij hoog. Mede daardoor zijn ook de arbeidsmarktperspectieven van veel hoger opgeleiden in Nederland goed. In de medische en paramedische richtingen zijn de arbeidsmarktperspectieven voor schoolverlaters goed door een combinatie van een hoge uitbreidings- en vervangingsvraag. In enkele grotere bètatechnische opleidingen zijn de arbeidsmarktperspectieven voor schoolverlaters goed door een hoge vervangingsvraag en een lage instroom vanuit het onderwijs op de arbeidsmarkt. Hoewel VMBO-schoolverlaters over het algemeen goede vooruitzichten hebben op werk, hebben de banen die voor hen beschikbaar zijn meestal betrekking op leer-werkbanen (BBL-trajecten) of juist banen met een tijdelijk karakter en slechte arbeidsvoorwaarden en loopbaanperspectieven. De mogelijkheden voor leer-werkbanen zijn het grootst in de technische en verzorgende richtingen. Van de MBO'ers die de komende zes jaar op de arbeidsmarkt instromen heeft ruim een derde goede tot zeer goede vooruitzichten, vooral in de verpleging en de verzorging, en enkele grote technische opleidingen. 


\section{Ontwikkelingen op de arbeidsmarkt, 2011-2016}

\section{$2.1 \quad$ Inleiding}

In dit hoofdstuk komen de verwachte vraag- en aanbodontwikkelingen op de arbeidsmarkt tot 2016 aan bod. Deze arbeidsmarktontwikkelingen worden gespecificeerd naar opleiding en beroep. Daarnaast worden de verwachte ontwikkelingen voor de komende jaren vergeleken met de gerealiseerde ontwikkelingen in de afgelopen periode (2006-20IO). In paragraaf 2.2 wordt de uitbreidingsvraag besproken. Deze vraag ontstaat als gevolg van een toe- of afname van de werkgelegenheid. De uitbreidingsvraag naar beroep is onder meer afhankelijk van werkgelegenheidsverschuivingen tussen sectoren en verschuivingen in de beroepenstructuur binnen sectoren. Voor de uitbreidingsvraag naar opleiding is daarnaast de verhoging van kwalificatievereisten van werkgevers ('upgrading') binnen beroepen van belang. Aan deze upgrading is al aandacht besteed in hoofdstuk I. Vervolgens komt in paragraaf 2.3 de vervangingsvraag naar beroep en opleiding aan bod. Deze vraag ontstaat als gevolg van vrijgekomen arbeidsplaatsen door bijvoorbeeld pensionering, arbeidsongeschiktheid of (tijdelijke) uittrede van de arbeidsmarkt vanwege huishoudelijke taken of zorgtaken. Bovendien kan er vervangingsvraag ontstaan wanneer werkenden van beroep of opleidingsachtergrond veranderen. Tevens wordt hier een gedachtenexperiment uitgevoerd waarin bekeken wordt welk effect een verhoging van de pensioengerechtigde leeftijd heeft op het niveau van de vervangingsvraag in de periode 20II-20I6. In paragraaf 2.4 wordt de totale vraag naar nieuwkomers op de arbeidsmarkt, de baanopeningen, besproken naar zowel beroep als opleiding. Deze baanopeningen zijn een optelsom van de totale (positieve) uitbreidings- en de vervangingsvraag. Hierna wordt in paragraaf 2.5 gekeken naar de aanbodkant van de arbeidsmarkt en wordt in kaart gebracht hoeveel nieuwe schoolverlaters en afgestudeerden de arbeidsmarkt in de prognoseperiode zullen betreden. Deze arbeidsmarktinstroom wordt gespecificeerd voor de 23 verschillende opleidingscategorieën. Ter afsluiting van dit hoofdstuk volgen in paragraaf 2.6 de belangrijkste conclusies. 


\subsection{Uitbreidingsvraag}

De verwachte werkgelegenheidsontwikkelingen worden weergegeven door de uitbreidingsvraag naar beroep en opleiding. Bij een positieve uitbreidingsvraag is er sprake van een toename van de werkgelegenheid voor de desbetreffende beroepsklasse of opleidingscategorie. Bij een negatieve uitbreidingsvraag wordt juist verwacht dat de werkgelegenheid zal krimpen. Het aantal werkenden in een beroep of opleiding wordt echter niet uitsluitend bepaald door de uitbreidingsvraag van werkgevers. De feitelijke ontwikkeling van de werkgelegenheid wordt namelijk bepaald door de afstemming van vraag en aanbod op de arbeidsmarkt. In deze paragraaf worden achtereenvolgens de verwachte uitbreidingsvraag naar beroep en opleiding tot 2016 besproken.

\section{Beroepen}

Tabel 2.I laat de uitbreidingsvraag in personen en groeipercentages zien voor de periode 20II-2016..$^{\text {sI }}$ Er wordt uitgegaan van het werkgelegenheidsniveau in het basisjaar 20I0. Naar verwachting zal de totale werkgelegenheid in deze periode met $3 \%$ toenemen. Dit betekent een gemiddelde jaarlijkse stijging van de werkgelegenheid met $0,4 \%$ tot 20I6. Echter, voor negen van de elf onderscheiden beroepsklassen is de verwachte uitbreidingsvraag tot 2016 negatief. De uitbreidingsvraag is alleen positief voor de medische en paramedische beroepen alsook voor de verzorgende en dienstverlenende beroepen. Voor beide beroepsklassen is de uitbreidingvraag dermate groot dat de negatieve uitbreidingsvraag in de andere beroepsklassen ruimschoots gecompenseerd wordt. De uitbreidingsvraag voor de elf onderscheiden beroepsklassen wordt hieronder besproken. Daarbij komen tevens de meest in het oog springende resultaten voor de 127 onderliggende beroepsgroepen aan de orde.

De uitbreidingsvraag is negatief voor de pedagogische beroepen. In deze beroepsklasse zullen naar verwachting tot 2016 ruim 19.000 banen verdwijnen. Dat is een gemiddeld jaarlijkse daling van de werkgelegenheid met $5 \%$. Uitgaande van de werkgelegenheid in 2010 zal de werkgelegenheid gedurende de zesjaarsperiode tot 2016 met jaarlijks gemiddeld o,8\% afnemen. Deze daling is vooral terug te zien bij de docenten $\mathrm{I}^{\mathrm{e}}$ graads en WO. Voor de docenten economisch-administratieve vakken $\mathrm{I}^{\mathrm{e}}$ graads en WO verdwijnt in deze periode zelfs een kwart van de werkgelegenheid. De vraag naar docenten $\mathrm{I}^{\mathrm{e}}$ graads en WO neemt nog meer af dan de vraag naar docenten $2^{\mathrm{e}}$ graads WO, hetgeen wijst op een continuering van de eerder ingezette trend van 'downgrading'. Het gevraagde opleidingsniveau van docenten wordt dus lager. Ook voor de rij-instructeurs zijn de voortekenen voor de komende jaren niet positief, met een gemiddelde jaarlijkse uitbreidingsvraag van $-3,9 \%$. Positieve uitschieters zijn er echter ook bij de pedagogische beroepen. Voor de sportinstructeurs, de onderwijskundigen

5I. Voor alle tabellen in dit hoofdstuk geldt dat de prognoseperiode, in tegenstelling tot voorgaande edities van deze rapportage, betrekking heeft op zes jaar in plaats van vijf jaar. Om deze prognoses goed te kunnen interpreteren zal steeds gekeken worden naar de gemiddelde jaarlijkse veranderingen. 
en pedagogen, en de zweminstructeurs is er sprake van positieve uitbreidingsvraag. Voor laatstgenoemden neemt de werkgelegenheid met gemiddeld jaarlijks 3,3\% toe.

\section{Tabel 2.1}

Uitbreidingsvraag naar beroepsklasse, in aantal en als percentage van de werkgelegenheid in 2010, prognose 2011-2016

\begin{tabular}{lccc} 
Beroepsklasse & Aantal & Totaal $(6 \mathrm{jr})$. & $\begin{array}{c}\text { Gem. jaarlijks } \\
\%\end{array}$ \\
\hline Pedagogische beroepen & -19.300 & -5 & $-0,8$ \\
\hline Creatieve beroepen & -12.400 & -8 & $-1,4$ \\
\hline Agrarische beroepen & -11.500 & -5 & $-0,9$ \\
\hline Technische en industrieberoepen & -15.100 & -1 & $-0,2$ \\
\hline Transportberoepen & -4.200 & -1 & $-0,2$ \\
\hline Medische en paramedische beroepen & 85.300 & 18 & 2,7 \\
\hline Economisch-administratieve beroepen & -24.600 & -1 & $-0,2$ \\
\hline Informaticaberoepen & -8.700 & -3 & $-0,5$ \\
\hline Sociaal-culturele beroepen & -3.600 & -1 & $-0,2$ \\
\hline Verzorgende en dienstverlenende beroepen & 181.200 & 14 & 2,2 \\
\hline Openbare orde- en veiligheidsberoepen & -600 & -1 & $-0,1$ \\
\hline Totaal (incl. overig) & & & 0,4 \\
Bron: ROA (AIS) & 186.300 & 3 & \\
\hline
\end{tabular}

Voor de creatieve beroepen (kunstenaars, grafische ontwerpers, taalkundigen, etc.) is de verwachte uitbreidingsvraag de komende jaren het meest negatief van alle beroepen. De werkgelegenheid neemt tot 2016 met gemiddeld jaarlijks I,4\% af. Met de kortingen op subsidies in de creatieve sector is een daling van de werkgelegenheid goed te verklaren. Van de negen onderliggende beroepsgroepen zijn het alleen de geestelijken voor wie de werkgelegenheid nog enigszins zal toenemen met gemiddeld $0,5 \%$ per jaar. In de overige creatieve beroepsgroepen daalt de werkgelegenheid, in het bijzonder voor de bibliotheekassistenten met gemiddeld jaarlijks $-9 \%$.

In de agrarische beroepen krimpt de werkgelegenheid de komende periode met gemiddeld jaarlijks $0,9 \%$. De relatieve werkgelegenheidsafname is het sterkst bij de landbouwmachinebestuurders en vissers. Hier daalt het aantal banen met gemiddeld jaarlijks 3,7\%. Milieuhygiënisten en agrarisch vertegenwoordigers vormen de meest positieve uitzondering binnen deze beroepsklasse. Voor deze beroepsgroep neemt de werkgelegenheid jaarlijks met gemiddeld 2,2\% toe.

Voor bijna twee derde van de 34 beroepsgroepen van de technische en industieberoepen wordt een negatieve uitbreidingsvraag verwacht. De werkgelegenheid in de technische en industrieberoepen zal naar verwachting met gemiddeld jaarlijks $0,2 \%$ afnemen. De uitbreidingsvraag in deze beroepsklasse is het meest negatief voor materiaalkundigen, grafisch productiepersoneel en elektrotechnici, namelijk gemiddeld jaarlijks ca. $-3,7 \%$. Daar staat tegenover dat de uitbreidingsvraag voor bijvoorbeeld natuurwetenschappers, weg- en waterbouwkundigen, technisch analisten en grafische 
vakkrachten behoorlijk positief is. Voor grafische vakkrachten stijgt de werkgelegenheid met gemiddeld jaarlijks 7,4\% zelfs het sterkst van alle I27 beroepsgroepen.

Evenals bij de technische en industrieberoepen wordt ook voor de transportberoepen een negatieve uitbreidingsvraag verwacht van gemiddeld jaarlijks -0,2\%. Deze vrij lichte krimp van de werkgelegenheid staat haaks op het conjunctuurgevoelige karakter van de transportberoepen. Dit komt wellicht doordat deze beroepsklasse de ergste klappen al eerder te verwerken heeft gehad. Voor de stewardessen neemt de werkgelegenheid de komende jaren zelfs met 2,I\% per jaar toe.

De werkgelegenheidsvooruitzichten voor de medici en paramedici zijn onverminderd positief. De jaarlijkse toename van de werkgelegenheid tot 2016 bedraagt $2,7 \%$. In geen enkele andere beroepsklasse is de uitbreidingsvraag de komende jaren zo groot. Mede door de vergrijzing van de bevolking en de daarmee gepaard gaande groeiende vraag naar zorg is er een stijgende behoefte aan medische en paramedische vakkrachten. Wel moet nog enige voorzichtigheid in acht genomen worden bij het interpreteren van de zeer grote uitbreidingsvraag, want nieuwe bezuinigingen in de sector kunnen een sterke toename van de werkgelegenheid verhinderen. De grootste uitbreidingsvraag is er voor verpleeghulpen en leerling-verpleegkundigen, gevolgd door artsen, verplegenden en doktersassistenten. Enige uitzondering op deze positieve prognoses wordt gevormd door de licht negatieve uitbreidingsvraag voor apothekersassistenten en medisch laboranten.

Voor de grootste beroepsklasse, de economisch-administratieve beroepen, wordt een negatieve uitbreidingsvraag voorzien in de periode 20II-20I6. De werkgelegenheid op de middellange termijn krimpt met gemiddeld $0,2 \%$ per jaar. Voor de 23 onderliggende beroepsgroepen lopen de prognoses echter aanzienlijk uiteen. Voor II van de 23 onderliggende beroepsgroepen wordt een negatieve uitbreidingsvraag verwacht, en voor de 12 andere een positieve uitbreidingsvraag. De ontwikkelingen variëren bovendien van heel negatief tot heel positief. Voor receptionisten en administratieve employés, juridisch en bestuurlijk medewerkers, en in het bijzonder verzekeringsagenten zijn de vooruitzichten het slechtst. Naar verwachting neemt de werkgelegenheid voor laatstgenoemden elk jaar zelfs met 7,I\% af. Positieve uitschieters kunnen er in deze beroepsklasse echter ook waargenomen worden. Voor organisatiedeskundigen en economen wordt bijvoorbeeld een relatief grote uitbreidingsvraag verwacht van respectievelijk 3,I\% en 5,I\% gemiddeld per jaar.

Net als bij de meeste andere beroepsklassen is ook de verwachte uitbreidingsvraag voor de informaticaberoepen negatief. Systeemanalisten zien de werkgelegenheid in hun beroepsgroep als enige iets toenemen, terwijl voor de overige drie beroepsgroepen juist een daling van de werkgelegenheid wordt voorzien. Voor informatici is de uitbreidingsvraag veruit het meest negatief, namelijk gemiddeld jaarlijks $-4,6 \%$. 
De voorspelde gemiddelde jaarlijkse negatieve uitbreidingsvraag voor de sociaalculturele beroepen komt overeen met die in de technische en industrieberoepen, transportberoepen en economisch-administratieve beroepen. Voor de sociaal-culturele beroepen geldt echter dat de negatieve uitbreidingsvraag veroorzaakt wordt door één enkele onderliggende beroepsgroep op middelbaar beroepsniveau, namelijk de activiteitenbegeleiders en medewerkers arbeidsbemiddeling. Voor de vier overige beroepsgroepen wordt juist een (licht) positieve uitbreidingsvraag verwacht.

De verzorgende en dienstverlenende beroepen zijn, naast de medische en paramedische beroepen, de enige beroepsklasse waarvoor de uitbreidingsvraagprognoses tot 2016 een positief beeld laten zien. In vergelijking met de werkgelegenheid in het basisjaar 2010 wordt tot 2016 een toename verwacht van gemiddeld $2,2 \%$ per jaar. Dit positieve algemene beeld is ook terug te zien in zeven van de tien onderliggende beroepsgroepen. Alleen het aantal banen onder winkeliers, bakkers en slagers, en café- en snackbarhouders zal dalen. Voor deze middenstanders speelt de economische conjunctuur een belangrijke rol. Binnen deze beroepsklasse wordt vooral voor de verzorgende beroepen een toename van de werkgelegenheid verwacht. Zo zal de werkgelegenheid onder de ziekenverzorgenden naar verwachting met gemiddeld jaarlijks $5,0 \%$ stijgen, en voor het verzorgende personeel met 3,3\%. Ook hieraan ligt in belangrijke mate de vergrijzende bevolking met de bijbehorende toenemende behoefte aan zorg ten grondslag.

De werkgelegenheid in de laatste beroepsklasse, de openbare orde- en veiligheidsberoepen, zal naar verwachting enigszins afnemen op de middellange termijn. Dit wordt veroorzaakt door slechts één onderliggende beroepsgroep. Voor de op middelbaar beroepsniveau opererende politieagenten, onderofficieren en beveiligingsemployés zal de werkgelegenheid namelijk iets afnemen. Daarentegen is de verwachte uitbreidingsvraag voor de politie-inspecteurs en officieren 3,6\%.

Om de prognoses van de uitbreidingsvraag voor de periode $201 \mathrm{I}-20 \mathrm{O} 6$ in perspectief te kunnen plaatsen worden deze prognoses vergeleken met de gerealiseerde werkgelegenheidsontwikkeling in de afgelopen jaren. In figuur 2.I geven de donkere balken de verwachte uitbreidingsvraag tot 2016 weer, en de lichte balken de gerealiseerde werkgelegenheidsontwikkeling in de periode 2006-20I0. Als basisjaar gelden het werkgelegenheidsniveau in 2010 respectievelijk 2005 .

Figuur 2.I laat duidelijk zien dat de gemiddelde jaarlijkse uitbreidingsvraag tussen 20 II en 2016 lager is dan de gerealiseerde werkgelegenheidsstijging in de voorbije periode 2006-20IO, welke gemiddeld jaarlijks I,2\% bedroeg. Bovendien laat de figuur zien wat reeds eerder aan bod is gekomen. De verwachte toename van de werkgelegenheid wordt veroorzaakt door de positieve uitbreidingsvraag in slechts twee beroepsklassen die gerelateerd zijn aan de gezondheidszorg: de medische en paramedische beroepen en de verzorgende en dienstverlenende beroepen. Voor deze beroepsklassen stijgt de werkgelegenheid naar verwachting harder dan in de voorgaande jaren. 
Voor de pedagogische beroepen, creatieve beroepen, transportberoepen, economischadministratieve beroepen, informaticaberoepen, sociaal-culturele beroepen en openbare orde- en veiligheidsberoepen wordt een negatieve uitbreidingsvraag verwacht, terwijl de werkgelegenheid tussen 2006 en 2010 nog steeg. Voor de agrarische beroepen en de technische en industrieberoepen blijft de werkgelegenheid naar verwachting dalen, maar minder snel dan in de voorgaande jaren.

\section{Figuur 2.1}

Uitbreidingsvraag naar beroepsklasse, prognose 2011-2016 en realisatie 2006-2010 als gemiddeld jaarlijks percentage van de werkgelegenheid in het basisjaar

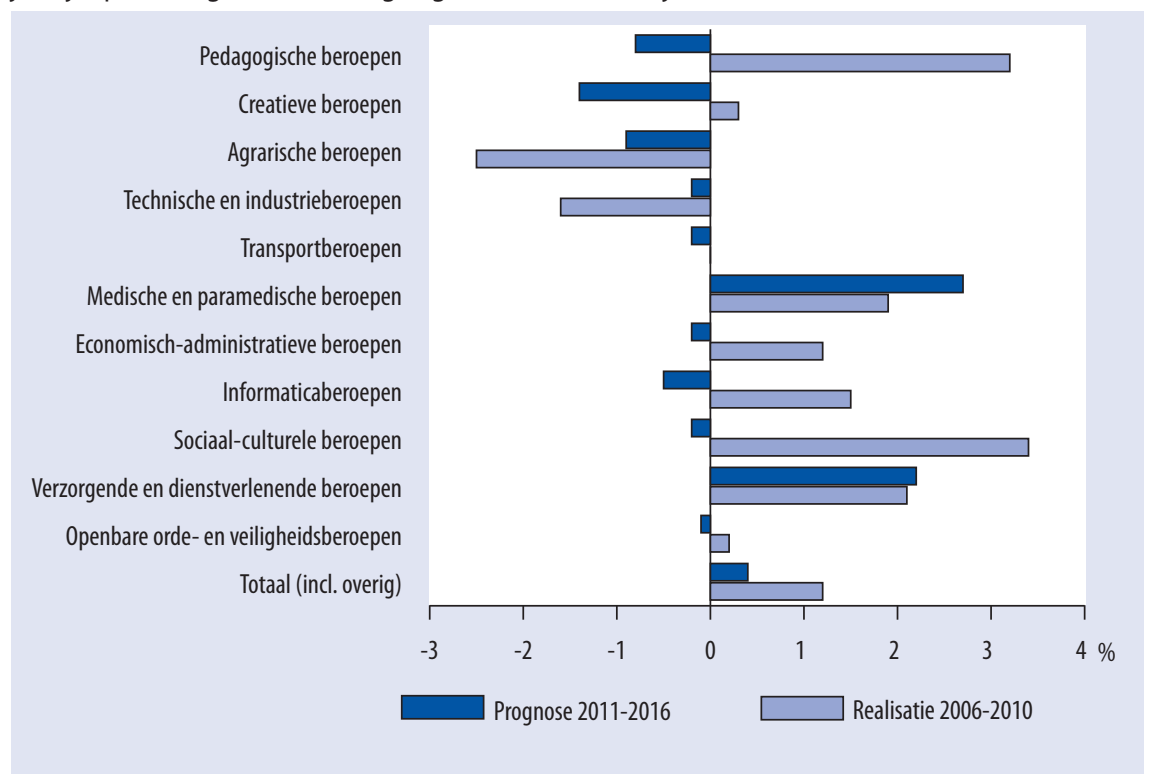

Bron: ROA(AIS)

\section{Opleidingen}

De werkgelegenheidsontwikkeling naar beroep is vertaald naar de werkgelegenheidsontwikkeling naar opleiding. Er wordt hierbij rekening gehouden met verschuivingen in de opleidingsstructuur binnen beroepen en de interactie met de aanbodzijde van de arbeidsmarkt. In hoofdstuk I zijn de verschillende componenten van de werkgelegenheidsontwikkeling naar opleiding beschreven, i.e. het bedrijfssectoreffect, beroepseffect, opleidingseffect en (passief) substitutie-effect. De uitbreidingsvraag kan afwijken van de feitelijke werkgelegenheidsontwikkeling wanneer het arbeidsaanbod kleiner is dan de vraag naar arbeid. Ook kan deze afwijken wanneer er een overschot aan arbeidskrachten met een specifieke opleidingsachtergrond bestaat en er meer personen met een dergelijke opleiding kunnen worden aangesteld. 
Tabel 2.2 laat de prognoses van de uitbreidingsvraag naar opleiding zien. Voor de prognoseperiode 20II-20I6 wordt de uitbreidingsvraag in zowel personen als in groeipercentages gepresenteerd. Voor slechts vijf van de onderscheiden opleidingscategorieën wordt een negatieve uitbreidingsvraag verwacht. Voor de zorgopleidingen zal naar verwachting op alle niveaus de werkgelegenheid toenemen. Zoals eerder aan de orde kwam, wordt dit in belangrijke mate veroorzaakt door de groeiende behoefte aan zorg voor ouderen. Ook voor $\mathrm{MBO}$ sociaal-cultureel worden veel nieuwe banen verwacht. Procentueel neemt de werkgelegenheid met gemiddeld jaarlijks -0,3\% het sterkst af voor de groene $\mathrm{VMBO}$ - en $\mathrm{MBO}$-opleidingen en voor $\mathrm{HBO}$ onderwijs.

Tabel 2.2

Uitbreidingsvraag naar opleidingscategorie, in aantal en als percentage van de werkgelegenheid in 2010, prognose 2011-2016

\begin{tabular}{|c|c|c|c|}
\hline Opleidingscategorie & Aantal & $\begin{array}{c}\text { Totaal (6 jr.) } \\
(\%)\end{array}$ & $\begin{array}{c}\text { Gem. jaarlijks } \\
(\%)\end{array}$ \\
\hline Basisonderwijs & 5.700 & 2 & 0,3 \\
\hline VMBO tl & 3.700 & 1 & 0,1 \\
\hline VMBO groen & -1.000 & -2 & $-0,3$ \\
\hline VMBO techniek & -4.700 & -1 & $-0,2$ \\
\hline VMBO economie & 2.900 & 2 & 0,3 \\
\hline VMBO verzorging & 11.300 & 7 & 1,1 \\
\hline HAVO/VWO & 13.200 & 2 & 0,4 \\
\hline MB0 groen & -2.900 & -2 & $-0,3$ \\
\hline MBO techniek & -5.400 & -1 & $-0,1$ \\
\hline MBO sociaal-cultureel & 61.000 & 12 & 1,8 \\
\hline MBO gezondheidszorg & 25.500 & 12 & 2,0 \\
\hline MBO economie & 7.100 & 1 & 0,2 \\
\hline $\mathrm{HBO}$ onderwijs & -5.800 & -2 & $-0,3$ \\
\hline HBO sociaal-cultureel & 8.800 & 2 & 0,4 \\
\hline HBO groen & 100 & 0 & 0,1 \\
\hline HBO techniek & 3.400 & 1 & 0,2 \\
\hline HBO paramedisch & 23.300 & 13 & 2,0 \\
\hline HBO economie & 600 & 0 & 0,0 \\
\hline W0 letteren en sociaal-cultureel & 7.900 & 3 & 0,5 \\
\hline W0 groen & 800 & 5 & 0,8 \\
\hline W0 techniek & 3.800 & 2 & 0,4 \\
\hline W0 medisch & 13.400 & 18 & 2,8 \\
\hline W0 economie en recht & 3.300 & 1 & 0,2 \\
\hline Totaal (incl. overig) & 186.300 & 3 & 0,4 \\
\hline
\end{tabular}


Bij de lager opgeleiden zal de werkgelegenheid naar verwachting met gemiddeld jaarlijks I,I\% het meest toenemen voor VMBO verzorging. Voor arbeidskrachten die alleen basisonderwijs genoten hebben, de zogenoemde ongeschoolden, en voor enkele VMBO-opleidingen is de verwachte uitbreidingsvraag voor de komende jaren positief. ${ }^{52} \mathrm{Bij}$ VMBO techniek is alleen de verwachte uitbreidingsvraag voor VMBO grafische techniek positief. De verwachte uitbreidingsvraag voor gediplomeerden van $\mathrm{HAVO} / \mathrm{VWO}$ wijkt niet af van het gemiddelde.

De verwachte uitbreidingsvraag voor middelbaar opgeleiden met een beroepsopleiding is nogal afhankelijk van de opleidingsrichting die het betreft. Terwijl de werkgelegenheid naar verwachting zal dalen voor $\mathrm{MBO}$ groen en $\mathrm{MBO}$ techniek, zal deze voor $\mathrm{MBO}$ sociaal-cultureel en $\mathrm{MBO}$ gezondheidszorg juist aanzienlijk stijgen. Bovendien geldt dat de onderliggende opleidingstypen uiteenlopende ontwikkelingen laten zien. Zo is de verwachte gemiddelde jaarlijkse uitbreidingsvraag voor MBO vliegtuigtechniek -0,7\%, en voor $\mathrm{MBO}$ procestechniek en $\mathrm{MBO}$ brood en banket I,4\%. Bij MBO sociaal-cultureel wordt met name een grote gemiddelde jaarlijkse uitbreidingsvraag verwacht voor $\mathrm{MBO}$ verzorging en $\mathrm{MBO}$ uiterlijke verzorging. De hoge uitbreidingsvraag voor $\mathrm{MBO}$ gezondheidszorg wordt veroorzaakt door twee opleidingstypen: verpleging en dokters-, tandarts- en dierenartsassistent. Binnen MBO economie met een verwachte uitbreidingsvraag van $0,2 \%$ gemiddeld per jaar springt geen enkel opleidingstype er duidelijk uit.

Op HBO-niveau wordt voor nagenoeg alle opleidingscategorieën een positieve uitbreidingsvraag verwacht. Enige uitzondering hierop vormen de lerarenopleidingen. Binnen deze opleidingscategorie $\mathrm{HBO}$ onderwijs wordt alleen voor de lerarenopleiding medisch en verzorging een toename van de werkgelegenheid verwacht. De lerarenopleiding talen heeft daarentegen met gemiddeld jaarlijks -I,I\% de grootste negatieve uitbreidingsvraag. Binnen $\mathrm{HBO}$ sociaal-cultureel varieert de verwachte uitbreidingsvraag per opleidingstype, van jaarlijks gemiddeld - $0,8 \%$ voor $\mathrm{HBO}$ documentatie en informatie tot $0,8 \%$ voor $\mathrm{HBO}$ horeca en $\mathrm{HBO}$ pedagogie. Bij $\mathrm{HBO}$ techniek hebben $\mathrm{HBO}$ laboratorium en $\mathrm{HBO}$ chemische technologie veruit de grootste verwachte uitbreidingsvraag. Van de verschillende technische HBO-opleidingen is de verwachte uitbreidingsvraag alleen negatief voor $\mathrm{HBO}$ werktuigbouwkunde. Bij $\mathrm{HBO}$ paramedisch zal de werkgelegenheid toenemen voor alle onderliggende opleidingstypen, maar met gemiddeld jaarlijks 2,2\% het meest voor verpleegkunde en (fysio)therapie. Binnen de richting economie in het hoger beroepsonderwijs wordt alleen voor HBO accountancy en bedrijfseconomie een daling van de werkgelegenheid verwacht. Voor alle andere opleidingstypen wordt een lichte stijging voorzien.

Voor de WO'ers stijgt naar verwachting de werkgelegenheid bij alle opleidingscate-

52. Dit is echter geen vrijbrief voor jongeren om niet in een startkwalificatie (minimaal MBO niveau 2 of HAVO/VWO) te investeren, want op de langere termijn krijgen veel lager opgeleiden te maken met gebrek aan carrièreperspectieven en werkloosheid als ze geen vervolgopleiding halen (zie ook hoofdstuk I). VMBO-niveau is inclusief niveau I van MBO (opleiding tot assistent beroepsbeoefenaar). 
gorieën. Daarbij is de stijging voor WO medisch veruit het grootst, in het bijzonder voor de opleidingstypen WO (dier)geneeskunde en WO tandheelkunde. Binnen WO letteren en sociaal-cultureel is alleen de uitbreidingsvraag voor WO letteren negatief. Voor WO techniek geldt dat de werkgelegenheid voor twee van de zes opleidingstypen zal dalen: WO elektrotechniek en WO informatica en bestuurlijke informatiekunde. De werkgelegenheid voor arbeidskrachten met een opleiding WO bouwkunde en WO civiele techniek zal naar verwachting met gemiddeld jaarlijks I,6\% respectievelijk I,4\% juist aanzienlijk stijgen. Evenals op HBO-niveau is de verwachte werkgelegenheidsontwikkeling binnen de WO-opleidingen economie alleen negatief voor het opleidingstype accountancy en belastingen.

\section{Figuur 2.2}

Uitbreidingsvraag naar opleidingcategorie, prognose 2011-2016 en realisatie 2006-2010 als gemiddeld jaarlijks percentage van de werkgelegenheid in het basisjaar

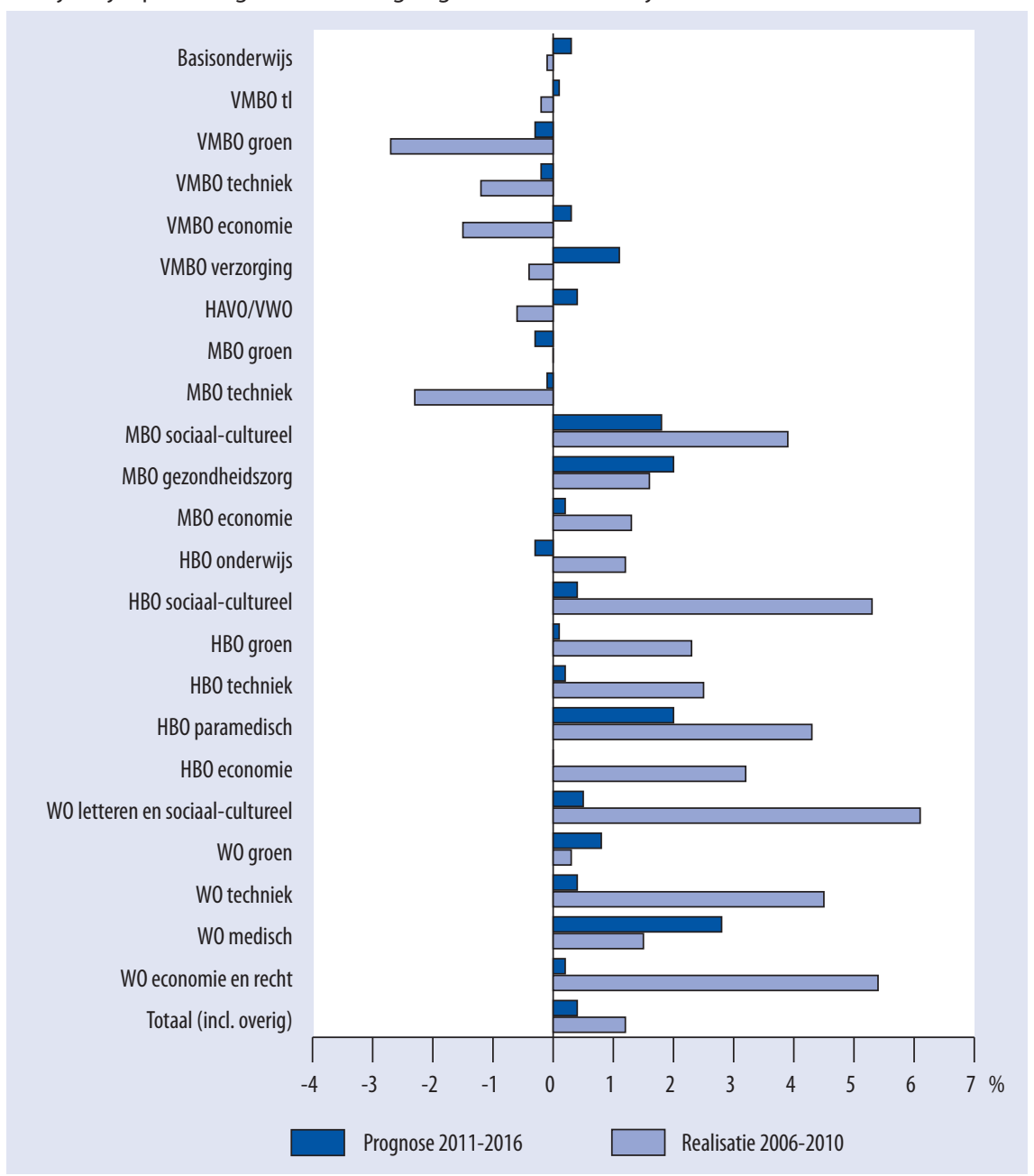

Bron: ROA (AIS) 
Uit figuur 2.2 blijkt in welke mate de prognoses voor de uitbreidingsvraag tot 2016 per opleidingscategorie afwijken van de werkgelegenheidsontwikkeling zoals deze de voorbije jaren is waargenomen. Uit de figuur blijkt duidelijk dat er uiteenlopende resultaten zijn op de verschillende opleidingsniveaus. Ten opzichte van de voorbije jaren neemt de verwachte uitbreidingsvraag voor lager opgeleiden toe voor alle opleidingscategorieën. Voor VMBO groen en VMBO techniek betekent dit overigens dat de verwachte werkgelegenheidskrimp lager zal zijn dan in de afgelopen jaren. Dit komt waarschijnlijk doordat het dieptepunt wat betreft de werkgelegenheid voor veel lager opgeleiden al eerder bereikt is. Afgezien van WO medisch en WO groen zal de geprognosticeerde uitbreidingsvraag voor de hoger opgeleiden daarentegen juist fors lager uitvallen in vergelijking met de voorbije periode. Hier ligt waarschijnlijk de terugloop van de werkgelegenheid bij de overheid aan ten grondslag waardoor relatief veel hoger opgeleiden geraakt worden. Voor middelbaar opgeleiden is er geen eenduidige algemene conclusie te trekken. Hier verschilt de ontwikkeling van de uitbreidingsvraag nogal per opleidingscategorie.

\subsection{Vervangingsvraag}

De vervangingsvraag is naast de uitbreidingsvraag de tweede vraagcomponent die in belangrijke mate de totale vraag naar nieuwkomers op de arbeidsmarkt bepaalt. De vervangingsvraag is de vraag naar nieuwe arbeidskrachten die ontstaat naar aanleiding van arbeidsplaatsen die vrijkomen doordat werkenden met pensioen gaan, arbeidsongeschikt raken of zich (tijdelijk) terugtrekken van de arbeidsmarkt. Indien de werkgelegenheid niet krimpt, leidt deze uitstroom van werkenden uiteindelijk tot vacatures die opgevuld moeten worden door nieuwkomers op de arbeidsmarkt.

Bij het bepalen van de vervangingsvraag per beroepsgroep moet er bovendien rekening gehouden worden met de baanmobiliteit tussen beroepsgroepen. Naast de arbeidsmarktuitstroom van werkenden is deze baanmobiliteit een belangrijke oorzaak van vervangingsvraag. Baanmobiliteit binnen één en dezelfde beroepsgroep leidt niet tot vervangingsvraag voor de desbetreffende beroepsgroep. Baanmobiliteit leidt overigens vaak niet tot vervangingsvraag naar opleiding. De opleidingsachtergrond van werkenden die overstappen naar een andere baan verandert immers niet, tenzij er sprake is van omscholing vanwege bijvoorbeeld hogere functievereisten. Hiervan is sprake als arbeidskrachten scholing hebben genoten die hun opleidingsniveau verhoogt of hun opleidingsrichting verandert. Derhalve wordt een onderscheid gemaakt tussen vervangingsvraag naar beroep en naar opleiding. Om deze redenen wijkt de vervangingsvraag naar opleiding af van de vervangingsvraag naar beroep.

Bij beroepen die structureel krimpen is de vervangingsvraag doorgaans lager dan de uitstroom. Dit wordt veroorzaakt doordat inkrimping van het personeelsbestand wordt opgevangen door natuurlijk verloop. Ook het stimuleren van de afvloeiing van oudere werknemers is een manier om reorganisaties en saneringen door te voeren. Een 
dalende arbeidsparticipatie van ouderen is echter geen economisch of maatschappelijk wenselijke situatie. Een toename van de arbeidsparticipatie van ouderen - maar ook van vrouwen - leidt tot een lagere vervangingsvraag. Een stijging van het aandeel oudere werkenden in de beroepsbevolking (bijvoorbeeld ouder dan 55 jaar) resulteert daarentegen in een toename van de vervangingsvraag voor de komende jaren.

\section{Beroepen}

In tabel 2.3 worden de prognoses voor de vervangingsvraag naar beroepsklasse gepresenteerd voor de periode 20II-20I6. Hierin wordt zowel de absolute vervangingsvraag weergegeven alsook de vervangingsvraag als percentage van de werkgelegenheid in 20IO. In totaal moeten tot 2016 ruim 2 miljoen arbeidskrachten vervangen worden doordat zij met pensioen gaan, arbeidsongeschikt raken of zich (tijdelijk) terugtrekken van de arbeidsmarkt. Dit betekent dat ten opzichte van het werkgelegenheidsniveau in 2010 gemiddeld jaarlijks $4,1 \%$ van de werkenden uitstroomt en vervangen moet worden. In algemene zin kan voor veel beroepsklassen met een hoge vervangingsvraag de vergrijzing van de beroepsbevolking als belangrijkste verklaring worden aangedragen. De hoge gemiddelde leeftijd van bepaalde beroepsklassen betekent dat veel oudere werkenden de komende jaren met pensioen zullen gaan waardoor er arbeidsplaatsen vrijkomen.

In de pedagogische beroepen moeten de komende jaren bovengemiddeld veel arbeidskrachten vervangen worden. Met name door de vergrijzing in deze beroepsklasse moet jaarlijks gemiddeld $5,0 \%$ van het totaal aantal werkenden vervangen worden. Voor docenten re graads en WO zonder specialisatie is de gemiddelde jaarlijkse vervangingsvraag met $\mathrm{I} 6,0 \%$ het hoogst maar ook een groot deel van de docenten landbouw en techniek Ie graads en WO, landbouw en techniek $2^{\mathrm{e}}$ graads en rij-instructeurs moet vervangen worden. Voor docenten sociale vakken $\mathrm{I}^{\mathrm{e}}$ graads en WO en sportinstructeurs is de verwachte vervangingsvraag met gemiddeld jaarlijks ca. 2,5\% aanmerkelijk lager.

De gemiddelde jaarlijkse vervangingsvraag voor de creatieve beroepen is bijna even hoog als voor de pedagogische beroepen. In deze beroepsklasse is de gemiddelde jaarlijkse vervangingsvraag hoog voor tolken, vertalers en schrijvers, maar in het bijzonder voor geestelijk verzorgers. Voor laatstgenoemden wordt een gemiddelde jaarlijkse vervangingsvraag van $20, \mathrm{I} \%$ verwacht, het hoogst van alle $\mathrm{I} 27$ beroepsgroepen. Dit wordt in belangrijke mate bepaald door de hoge gemiddelde leeftijd van geestelijk verzorgers.

Van alle beroepsklassen wordt voor de agrarische beroepen veruit de hoogste vervangingsvraag voorspeld. Tot 2016 moet jaarlijks $7,2 \%$ van het totaal aantal agrariërs vervangen worden omdat zij van beroep wisselen of de arbeidsmarkt verlaten. Zes van de zeven onderscheiden beroepsgroepen zullen naar verwachting een bovengemiddelde vervangingsvraag hebben. Vooral voor landbouwkundigen en agrarische 
bedrijfshoofden wordt een hoge vervangingsvraag verwacht. De gemiddelde jaarlijkse vervangingsvraag voor deze vergrijzende beroepsgroepen bedraagt 9,3\%.

De vervangingsvraag voor de technische en industrieberoepen is van vergelijkbare omvang als voor de pedagogische beroepen. Met een gemiddelde vervangingsvraag van $5,0 \%$ per jaar is deze bovengemiddeld. Binnen deze beroepsklasse wordt voor enkele beroepsgroepen een erg hoge vervangingsvraag verwacht, zoals voor bedrijfshoofden metaalbewerking, maar ook bijvoorbeeld laboratorium-assistenten, schoenen kleermakers, en conciërges zullen - door hun hoge gemiddelde leeftijd - vaak vervangen moeten worden. Daar staat tegenover dat de vervangingsvraag voor laboranten bijvoorbeeld slechts gemiddeld I,9\% per jaar bedraagt. Voor werktuigbouwkundigen en procesoperators is de verwachte vervangingsvraag eveneens aanzienlijk lager dan gemiddeld, namelijk respectievelijk 2,5\% en 2,6\% gemiddeld per jaar.

De verwachte vervangingsvraag voor arbeidskrachten in de transportberoepen is het op één na hoogst van alle onderscheiden beroepsklassen. In deze beroepen moet tussen $20 I$ en 2016 gemiddeld jaarlijks $5,4 \%$ van het totaal aantal werkenden vervangen worden. Dit wordt met name veroorzaakt door de hoge vervangingsvraag van gemiddeld jaarlijks 6,6\% voor chauffeurs.

In de medische en paramedische beroepen is de gemiddelde jaarlijkse vervangingsvraag met $3,8 \%$ iets lager dan gemiddeld. Dat de vervangingsvraag in deze beroepsklasse relatief laag is wil overigens niet zeggen dat dit voor alle onderliggende beroepsgroepen geldt. De hoogste vervangingsvraag in deze beroepsklasse wordt de komende jaren verwacht voor artsen, namelijk gemiddeld jaarlijks $6,4 \%$.

Ook in de economisch-administratieve beroepen wordt met gemiddeld jaarlijks 3,7\% de komende jaren een lager dan gemiddelde vervangingsvraag voorspeld. Van de 23 economisch-administratieve beroepsgroepen springen de juridisch bestuurlijk medewerkers er duidelijk bovenuit. De gemiddelde jaarlijkse vervangingsvraag voor deze groep is $7,5 \%$.

Van alle elf onderscheiden beroepsklassen zal de vervangingsvraag op de middellange termijn het laagst zijn voor de informaticaberoepen. Uitgaande van de werkgelegenheid in deze beroepen in 2010 bedraagt de gemiddelde jaarlijkse vervangingsvraag $2,6 \%$. Dit wordt grotendeels verklaard door het grote aantal jonge mannen in deze beroepsklasse. Deze groep gaat nog lang niet met pensioen en bovendien verlaten zij de arbeidsmarkt ook aanzienlijk minder vaak dan vrouwen om zorgtaken te verrichten. Bij de verschillende onderliggende beroepsgroepen wordt alleen een bovengemiddeld hoge vervangingsvraag voorzien voor de technisch systeemanalisten.

Ook voor de sociaal-culturele beroepen wordt een relatief lage vervangingsvraag verwacht. De gemiddelde jaarlijkse vervangingsvraag in deze beroepsklasse bedraagt $3,0 \%$. De hoge vervangingsvraag van gemiddeld jaarlijks $7,5 \%$ voor de beroepsgroep 
hoofden sociaal-cultureel werk en personeel en arbeid vormt hier de grootste uitzondering.

Van alle arbeidskrachten in de verzorgende en dienstverlenende beroepen moet ieder jaar gemiddeld 3,6\% vervangen worden door nieuwe arbeidskrachten, omdat zij hun beroep verlaten. Voor café- en snackbarhouders ligt dit percentage met 6,6\% aanzienlijk hoger dan het gemiddelde in deze beroepsklasse. Ook vakkenvullers en bakkers en slagers moeten in vergelijking met andere verzorgende en dienstverlenende beroepen relatief vaak vervangen worden. De over het algemeen jonge vakkenvullers stromen vaak door naar andere beroepen, waardoor een hoge vervangingsvraag van gemiddeld jaarlijks 5,8\% ontstaat. Bij zelfstandige café- en snackbarhouders speelt de invoering van het rookverbod en de hiermee samenhangende teruglopende klandizie wellicht een voorname rol. Hierdoor besluit een deel van hen, al dan niet gedwongen, hun zaak te sluiten en voor een ander beroep te kiezen. Bakkers en slagers die het ook moeilijk hebben, verliezen net als veel andere speciaalzaken een deel van hun klantenkring aan supermarkten. Om die reden kan een deel van hen ervoor kiezen de eigen zaak van de hand te doen en voor een ander beroep te kiezen.

\section{Tabel 2.3}

Vervangingsvraag naar beroepsklasse, in aantal en als percentage van de werkgelegenheid in 2010, prognose 2011-2016

\begin{tabular}{lccc}
\hline Beroepsklasse & Aantal & Totaal (6 jr.) & Gem. jaarlijks \\
$\%$ & & 34 & 5,0 \\
\hline Pedagogische beroepen & 142.300 & 33 & 4,9 \\
\hline Creatieve beroepen & 50.800 & 52 & 7,2 \\
\hline Agrarische beroepen & 113.100 & 34 & 5,0 \\
\hline Technische en industrieberoepen & 443.500 & 37 & 5,4 \\
\hline Transportberoepen & 147.000 & 25 & 3,8 \\
\hline Medische en paramedische beroepen & 123.200 & 24 & 3,7 \\
\hline Economisch-administratieve beroepen & 506.400 & 17 & 2,6 \\
\hline Informaticaberoepen & 47.300 & 20 & 3,0 \\
\hline Sociaal-culturele beroepen & 64.200 & 24 & 3,6 \\
\hline Verzorgende en dienstverlenende beroepen & 312.900 & 21 & 3,3 \\
\hline Openbare orde- en veiligheidsberoepen & 24.700 & & 4,1
\end{tabular}

Bron: ROA (AIS)

De vervangingsvraag voor orde- en veiligheidsberoepen is vrij laag. Voor politieagenten, onderofficieren en beveiligingsemployés is de vervangingsvraag zelfs het laagst van alle onderscheiden beroepsgroepen. Dit is wellicht het gevolg van de aangekondigde bezuinigingen die deze beroepsgroepen zullen treffen. In deze beroepsgroep hoeft tot 2016 jaarlijks slechts I,2\% van het totaal aantal werkenden vervangen te 
worden. Bij de politie-inspecteurs en officieren is de verwachte gemiddelde jaarlijkse vervangingsvraag hoog, namelijk 5,3\%.

In figuur 2.3 wordt de geprognosticeerde vervangingsvraag tot 2016 afgezet tegen de waargenomen vervangingsvraag in de voorbije jaren. Is de verwachte totale vervangingsvraag tot 2016 gemiddeld jaarlijks 4,I\%, in de periode 2006-20IO was de waargenomen vervangingsvraag met gemiddeld jaarlijks I,9\% aanzienlijk lager. Deze forse stijging houdt waarschijnlijk verband met de toenemende vergrijzing van werkenden en de daarmee samenhangende uitstroom van de arbeidsmarkt. Wanneer deze grote groep oudere werknemers met pensioen gaat, en werkgevers deze vrijgekomen arbeidsplaatsen ook daadwerkelijk opnieuw willen opvullen, dan is het voor de hand liggend dat er extra vervangingsvraag ontstaat. Uit de figuur blijkt verder dat dit algemene beeld, i.e. een hogere verwachte vervangingsvraag voor de komende jaren ten opzichte van de waargenomen vervangingsvraag in de voorbije jaren, eveneens is terug te zien bij elke afzonderlijke beroepsklasse. Verder kan er uit de figuur geconcludeerd worden dat de vervangingsvraag naar verwachting het meest zal toenemen in de agrarische beroepen, gevolgd door de pedagogische beroepen en de transportberoepen. In de informaticaberoepen, de openbare orde- en veiligheidsberoepen, en de verzorgende en dienstverlenende beroepen is deze toename aanmerkelijk kleiner.

\section{Figuur 2.3}

Vervangingsvraag naar beroepsklasse, prognose 2011-2016 en realisatie 2006-2010 als gemiddeld jaarlijks percentage van de werkgelegenheid in het basisjaar

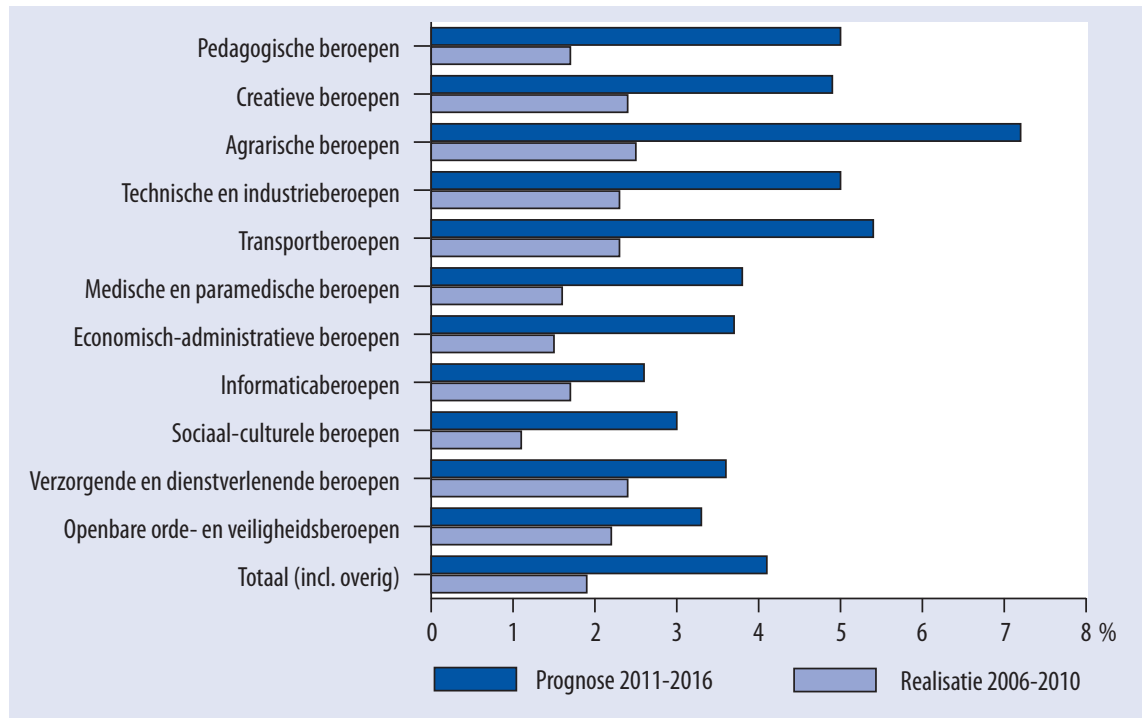

Bron: $\operatorname{ROA}(\mathrm{AIS})$ 


\section{Lagere vervangingsvraag door uitstel pensioenleeftijd}

Om de tekorten op de arbeidsmarkt op te vangen die ontstaan doordat een groot deel van de werkenden uitstroomt vanwege het bereiken van de pensioengerechtigde leeftijd, wordt vaak gewezen op het belang van het langer inzetbaar houden van deze arbeidskrachten. Door de verhoging van de pensioenleeftijd blijven arbeidskrachten langer voor de arbeidsmarkt behouden en zodoende zouden in Nederland de tekorten verminderd kunnen worden. Vanuit dit perspectief wordt de gemiddelde pensioenleeftijd met twee jaar verhoogd. Er wordt gekeken welk effect deze maatregel voor de verschillende onderliggende beroepsgroepen sorteert. Om hier een indicatie van te geven wordt in deze paragraaf een gedachte-experiment uitgevoerd waarbij een verhoging van de pensioenleeftijd met twee jaar is geëffectueerd over een prognosetermijn van zes jaar, bijvoorbeeld door de pensioengerechtigde leeftijd van 65 naar 67 jaar te verhogen. ${ }^{53}$

\section{Tabel 2.4}

Vervangingsvraag naar beroepsklasse als de pensioenleeftijd met twee jaar wordt uitgesteld, gemiddeld jaarlijks percentage van de werkgelegenheid in 2010, prognose 2011-2016

\begin{tabular}{|c|c|c|c|}
\hline Beroepsklasse & $\begin{array}{l}\text { Basisscenario } \\
\text { gem. jaarlijks } \\
\%\end{array}$ & $\begin{array}{c}1 / 3 \text { niet met } \\
\text { pensioen } \\
\text { gem. jaarlijks } \\
\%\end{array}$ & $\begin{array}{c}\text { Verschil } \\
\text { gem. jaarlijks } \\
\% \text {-punt }\end{array}$ \\
\hline Pedagogische beroepen & 5,0 & 3,7 & $-1,3$ \\
\hline Creatieve beroepen & 4,9 & 3,7 & $-1,2$ \\
\hline Agrarische beroepen & 7,2 & 5,2 & $-2,0$ \\
\hline Technische en industrieberoepen & 5,0 & 3,7 & $-1,3$ \\
\hline Transportberoepen & 5,4 & 3,9 & $-1,5$ \\
\hline Medische en paramedische beroepen & 3,8 & 3,0 & $-0,8$ \\
\hline Economisch-administratieve beroepen & 3,7 & 2,7 & $-1,0$ \\
\hline Informaticaberoepen & 2,6 & 2,0 & $-0,6$ \\
\hline Sociaal-culturele beroepen & 3,0 & 2,1 & $-0,9$ \\
\hline Verzorgende en dienstverlenende beroepen & 3,6 & 3,0 & $-0,6$ \\
\hline Openbare orde- en veiligheidsberoepen & 3,3 & 2,7 & $-0,6$ \\
\hline Totaal (incl. overig) & 4,1 & 3,1 & $-1,0$ \\
\hline
\end{tabular}

53. In het basisscenario gaan alle werkenden die in 2010 tussen 60 en 64 jaar oud waren met pensioen in de zesjaarsperiode tot 20I6. In het alternatieve scenario gaat een derde hiervan niet met pensioen. Dit is niet erg realistisch omdat er binnen een hele korte periode een grote effectiviteit moet zijn van de maatregelen gericht op het uitstellen van uittrede door pensionering. Er zullen zwaardere maatregelen moeten worden genomen om de uittrede van ouderen door pensionering in de periode tot 2016 in de veronderstelde mate te verminderen. De uitkomsten van tabel 2.4 zijn dus slechts indicatief voor de grote verschillen die er kunnen bestaan tussen beroepsgroepen bij het nemen van maatregelen. 
Tabel 2.4 geeft een indicatie van het effect van uitstel van de pensioenleeftijd op de verwachte vervangingsvraag. Door de verhoging van de pensioenleeftijd met twee jaar zou de totale vervangingsvraag tot 2016 dalen van gemiddeld jaarlijks 4,I\% van de werkgelegenheid naar 3,I\%. Dit komt doordat het bestaande arbeidsaanbod langer beschikbaar blijft, met andere woorden doordat de arbeidsparticipatie van ouderen stijgt. Deze macro-economische maatregel zou echter niet voor alle beroepsgroepen tot eenzelfde effect leiden. Het effect hangt immers af van de mate van vergrijzing in het betreffende beroep. Waar bij de informaticaberoepen, de verzorgende en dienstverlenende beroepen en de openbare orde- en veiligheidsberoepen een verhoging van de pensioenleeftijd met twee jaar leidt tot een gemiddelde jaarlijkse daling van de vervangingsvraag van $0,6 \%$-punt, zou dit bij de agrarische beroepen en transportberoepen tot een veel grotere daling leiden. Bij de agrarische beroepen zou de gemiddelde jaarlijkse vervangingsvraag in een dergelijke situatie zelfs met 2,0\%-punt afnemen. Voor deze beroepsklasse zal een verhoging van de pensioenleeftijd heel effectief zijn, omdat een groot deel van de werkenden 50 jaar of ouder is.

\section{Tabel 2.5}

Beroepsgroepen met het kleinste effect van een verhoging van de pensioenleeftijd met twee jaar op de vervangingsvraag tot 2016, gemiddeld jaarlijks percentage van de werkgelegenheid in 2010

\begin{tabular}{lccc|}
\hline Beroepsgroep & $\begin{array}{c}\text { Basisscenario } \\
\text { gem. jaarlijks } \\
\%\end{array}$ & $\begin{array}{c}1 / 3 \text { niet met } \\
\text { pensioen } \\
\text { gem. jaarlijks } \\
\%\end{array}$ & $\begin{array}{c}\text { gem. jaarlijks } \\
\% \text {-punt }\end{array}$ \\
\hline Elektrotechnici & 2,9 & 2,9 & 0,0 \\
\hline Stewards & 2,8 & 2,8 & 0,0 \\
\hline Zweminstructeurs & 2,8 & 2,8 & 0,0 \\
\hline Vakkenvullers & 4,5 & 4,4 & 0,0 \\
\hline Politieagenten, onderofficieren en beveiligingsemployés & 0,9 & 0,8 & $-0,1$ \\
\hline Docenten sociale vakken (1e graads en W0) & 1,8 & 1,7 & $-0,1$ \\
\hline Laboranten & 1,4 & 1,3 & $-0,1$ \\
\hline Vliegers, scheepskapiteins en leidinggevenden transport & 1,4 & 1,3 & $-0,2$ \\
\hline Grafisch ontwerpers & 2,3 & 2,1 & $-0,2$ \\
\hline Afdelingshoofden zorginstelling & 2,6 & 2,3 & $-0,3$ \\
\hline Bron: ROA & & & \\
\hline
\end{tabular}

Ook voor de onderliggende beroepsgroepen kan geanalyseerd worden in welke mate een dergelijke maatregel tot een daling van de vervangingsvraag zou kunnen leiden. Tabel 2.5 laat voor de periode 20II-20I6 zien voor welke tien beroepsgroepen er geen of nauwelijks effect is van uitstel van pensionering. Voor elektrotechnici, stewardessen, zweminstructeurs en vakkenvullers leidt uitstel van de pensioenleeftijd helemaal niet tot een daling van de vervangingsvraag. Voor bijvoorbeeld vakkenvullers is dit eenvoudig te verklaren doordat zij op jonge leeftijd doorstromen naar andere beroepen, vaak na het afronden van een opleiding. Het verhogen van de pensioen- 
leeftijd biedt dan vanzelfsprekend geen oplossing voor het vergroten van het arbeidsaanbod. Bij stewardessen biedt het verhogen van de pensioenleeftijd ook geen oplossing, maar heeft het grote verloop wellicht te maken met het gegeven dat de privésituatie (gezin, kinderen, etc.) moeilijk te combineren is met een carrière als stewardess.

Er zijn echter ook beroepsgroepen waarvoor gedurende de periode 20II-20I6 een uitstel van de pensioenleeftijd wel degelijk effect heeft op de vervangingsvraag. Tabel 2.6 geeft de tien beroepsgroepen weer waarvoor deze maatregel de komende periode het grootste effect zou hebben. Wanneer arbeidskrachten in de leeftijd van 60 jaar of ouder twee jaar langer doorwerken, dan neemt de gemiddelde jaarlijkse vervangingsvraag met 3,0\%-punt het meest af voor conciërges. Deze beroepsgroep wordt gekenmerkt door een hoge gemiddelde leeftijd, waardoor het direct merkbaar is als er langer wordt doorgewerkt. Voor de afname van de vervangingsvraag bij agrarische bedrijfshoofden en geestelijk verzorgers bij latere uittrede geldt eenzelfde verklaring.

\section{Tabel 2.6}

Beroepsgroepen met het grootste effect van een verhoging van de pensioenleeftijd met twee jaar op de vervangingsvraag tot 2016, gemiddeld jaarlijks percentage van de werkgelegenheid in 2010

\begin{tabular}{lccc|}
\hline Beroepsgroep & $\begin{array}{c}\text { Basisscenario } \\
\text { gem. jaarlijks } \\
\%\end{array}$ & $\begin{array}{c}1 / 3 \text { niet met } \\
\text { pensioen } \\
\text { gem. jaarlijks } \\
\%\end{array}$ & $\begin{array}{c}\text { gem. jaarlijks } \\
\% \text {-punt }\end{array}$ \\
\hline Conciërges & 8,9 & 5,9 & $-3,0$ \\
\hline Agrarische bedrijfshoofden & 7,1 & 4,6 & $-2,5$ \\
\hline Geestelijk verzorgers & 15,4 & 13,1 & $-2,3$ \\
\hline Confectie-arbeiders & 6,7 & 4,5 & $-2,2$ \\
\hline Docenten letteren (1e graads en W0) & 5,7 & 3,6 & $-2,1$ \\
\hline Elektronicamonteurs & 6,4 & 4,3 & $-2,1$ \\
\hline Docenten landbouw en techniek (2e graads) & 6,8 & 4,7 & $-2,1$ \\
\hline Weg- en waterbouwkundige vakkrachten & 6,1 & 4,3 & $-1,8$ \\
\hline Grafisch productiepersoneel & 5,0 & 3,2 & $-1,8$ \\
\hline Docenten economisch-administratieve vakken (1e graads en W0) & 4,5 & 2,8 & $-1,7$ \\
\hline
\end{tabular}

\section{Opleidingen}

Bij de vervangingsvraag naar opleidingscategorie moet niet alleen rekening gehouden worden met vertrekkende arbeidskrachten die vervangen moeten worden nadat zij met pensioen gaan, arbeidsongeschikt raken, of tussentijds uittreden om bijvoorbeeld zorgtaken te verrichten. Hier moet eveneens rekening gehouden worden met de omvangrijke groep van reeds werkenden die besluit om verder te leren. In het kader van Leven Lang Leren en de employability van werkenden krijgt de continue ontwikkeling van werknemers steeds meer aandacht. Wanneer werkenden dankzij 
deze bijscholing in het post-initieel onderwijs een diploma behalen dat hun opleidingsniveau verhoogt dan wel hun opleidingsrichting verandert, ontstaat er vervangingsvraag naar nieuwe arbeidskrachten met de opleidingsachtergrond die deze doorleerders aanvankelijk hadden. Wel moet er dan natuurlijk tegelijkertijd sprake zijn van positieve uitbreidingsvraag, want bij krimpende werkgelegenheid kunnen werkgevers ervoor kiezen om de vrijgekomen vacatures voorlopig niet op te vullen. ${ }^{54}$ Doorgaans speelt het doorleren vooral een rol bij de lager opgeleiden. In de praktijk gaat het dan vaak om gediplomeerde of zelfs ongediplomeerde VMBO'ers die zijn ingestroomd in de beroepsbegeleidende leerweg (BBL), waarbij het werken in een baan gecombineerd wordt met de deelname aan een niveauverhogende vervolgopleiding. Als gevolg hiervan ontstaat er vervangingsvraag naar nieuwe instromers met een VMBO-opleidingsachtergrond.

Tabel 2.7 geeft de vervangingsvraag naar opleidingscategorie weer voor de periode 20II-20I6. In de tabel worden zowel de vervangingsvraag in personen als in percentages van de werkgelegenheid weergegeven. In totaal moeten er tot 2016 bijna I.795.000 banen opgevuld worden. Uitgaande van de werkgelegenheid in het basisjaar 2010 betekent dit dat gemiddeld jaarlijks 3,7\% van het totaal aantal werkenden vervangen moet worden. Er bestaan daarbij duidelijke verschillen in de grootte van de vervangingsvraag per opleidingscategorie.

Er wordt een bovengemiddelde vervangingsvraag voorspeld voor de lager opgeleiden van alle opleidingscategorieën. Zoals reeds eerder vermeld kan dit in belangrijke mate verklaard worden door doorleereffecten die het meest voorkomen bij lager opgeleiden. Voor $\mathrm{VMBO}$ theoretische leerweg $(\mathrm{tl})$ en $\mathrm{VMBO}$ verzorging is de vervangingsvraag het hoogst, respectievelijk 5,I\% en 5,2\% gemiddeld per jaar. Bij VMBO verzorging kan het hoge aandeel jonge vrouwen ook een belangrijke rol spelen. Zij kunnen de arbeidsmarkt (tijdelijk) verlaten door zwangerschap en vervolgens voor kortere of langere tijd thuisblijven om voor hun kind(eren) te zorgen. Wat betreft de onderliggende opleidingstypen geldt voor de lager opgeleiden dat de verwachte vervangingsvraag met gemiddeld jaarlijks 5,5\% het hoogst is voor VMBO bouwtechniek.

Op HAVO/VWO-niveau is vaak sprake van jongeren die in eerste instantie besluiten om te gaan werken, deze keuze vervolgens heroverwegen, en uiteindelijk toch weer een studie oppakken. Zodoende ontstaat er vervangingsvraag voor nieuwkomers met een $\mathrm{HAVO/VWO-diploma.} \mathrm{Bij} \mathrm{de} \mathrm{middelbare} \mathrm{beroepsopleidingen} \mathrm{is} \mathrm{de} \mathrm{vervangingsvraag}$ naar verwachting het hoogst voor $\mathrm{MBO}$ groen en daarbinnen met gemiddeld jaarlijks $4,8 \%$ voor het opleidingstype voeding, natuur en milieu. Hoewel de verwachte

54. Deze doorleerders leiden tot vervangingsvraag naar opleiding die niet wordt meegerekend bij de vervangingsvraag naar beroep. Bij de vervangingsvraag naar opleiding worden echter niet degenen meergerekend die wel van beroepsgroep maar niet van opleidingsniveau- of richting veranderen. Uiteraard kunnen er wel situaties zijn waarin werkenden min of meer tegelijkertijd van opleiding en beroep veranderen. Maar over het algemeen zijn de vervangingsvraag naar beroep en opleiding niet gelijk aan elkaar. 
vervangingsvraag voor $\mathrm{MBO}$ techniek slechts iets hoger dan gemiddeld is, wordt voor de onderliggende opleidingstypen $\mathrm{MBO}$ bouw en $\mathrm{MBO}$ werktuigbouw en mechanische techniek een hoge vervangingsvraag verwacht. Voor $\mathrm{MBO}$ operationele techniek en vliegtuigtechniek is deze daarentegen juist erg laag. Ook binnen $\mathrm{MBO}$ economie wordt er een erg lage vervangingsvraag verwacht voor twee specifieke opleidingstypen, namelijk MBO ICT en MBO toerisme en recreatie.

\section{Tabel 2.7}

Vervangingsvraag naar opleidingscategorie, in aantal en als percentage van de werkgelegenheid in 2010, prognose 2011-2016

\begin{tabular}{|c|c|c|c|}
\hline Opleidingscategorie & Aantal & $\begin{array}{c}\text { Totaal (6 jr.) } \\
\%\end{array}$ & $\begin{array}{c}\text { Gem. jaarlijks } \\
\%\end{array}$ \\
\hline Basisonderwijs & 92.900 & 28 & 4,2 \\
\hline VMBO tl & 161.400 & 35 & 5,1 \\
\hline VMBO groen & 15.700 & 29 & 4,4 \\
\hline VMBO techniek & 106.100 & 27 & 4,1 \\
\hline VMBO economie & 41.700 & 26 & 4,0 \\
\hline VMBO verzorging & 58.600 & 35 & 5,2 \\
\hline HAVO/VWO & 160.700 & 27 & 4,0 \\
\hline MBO groen & 43.500 & 31 & 4,6 \\
\hline MBO techniek & 212.600 & 27 & 4,0 \\
\hline MBO sociaal-cultureel & 104.600 & 20 & 3,0 \\
\hline MBO gezondheidszorg & 40.100 & 19 & 3,0 \\
\hline MB0 economie & 179.700 & 23 & 3,5 \\
\hline HBO onderwijs & 104.600 & 32 & 4,7 \\
\hline HBO sociaal-cultureel & 75.700 & 20 & 3,1 \\
\hline HBO groen & 3.500 & 10 & 1,6 \\
\hline HBO techniek & 71.000 & 26 & 3,9 \\
\hline HBO paramedisch & 32.500 & 18 & 2,7 \\
\hline HBO economie & 67.500 & 16 & 2,5 \\
\hline WO letteren en sociaal-cultureel & 62.300 & 23 & 3,5 \\
\hline WO groen & 1.100 & 7 & 1,1 \\
\hline W0 techniek & 35.700 & 23 & 3,5 \\
\hline WO medisch & 25.600 & 34 & 5,0 \\
\hline WO economie en recht & 46.100 & 18 & 2,9 \\
\hline Totaal (incl. overig) & 1.794 .900 & 24 & 3,7 \\
\hline
\end{tabular}

Bron: ROA (AIS)

De vervangingsvraag voor hoger opgeleiden is in het algemeen relatief laag. Dit is in lijn met de verwachting, aangezien hoger opgeleiden in mindere mate hun opleidingsniveau kunnen verhogen door bijscholing in vergelijking met middelbaar en 
lager opgeleiden. Voor de groene opleidingen op zowel HBO- als WO-niveau is de vervangingsvraag zeer laag. Deze groep is vergeleken met andere hoger opgeleiden relatief jong. $\mathrm{HBO}$ onderwijs en WO medisch zijn juist twee opleidingscategorieën waarvoor de komende jaren een relatief groot deel van de medewerkers vervangen zal moeten worden. Voor beide opleidingscategorieën geldt dat dit verklaard kan worden door de hoge mate van vergrijzing en de bijbehorende vervanging van een aanzienlijk deel van de medewerkers dat tussen $201 \mathrm{I}$ en 2016 met pensioen gaat. $\mathrm{Bij} \mathrm{HBO}$ onderwijs is het verder opvallend dat de vervangingsvraag bovengemiddeld hoog is voor elk afzonderlijk opleidingstype binnen deze richting. Er ontstaat in het bijzonder een hoge vervangingsvraag van gemiddeld jaarlijks meer dan $5 \%$ van de werkgelegenheid voor de lerarenopleidingen: talen, medisch en verzorging en natuur en techniek. Bij WO medisch moet de oorzaak gezocht worden in de hoge vervangingsvraag voor WO (dier)geneeskunde en WO tandheelkunde. Andere HBO- en WO-opleidingstypen waarvoor een relatief hoge vervangingsvraag van gemiddeld jaarlijks ca. $5 \%$ of meer wordt verwacht zijn terug te vinden bij $\mathrm{HBO}$ techniek en WO letteren en sociaalcultureel, te weten $\mathrm{HBO}$ civiele techniek, $\mathrm{HBO}$ laboratorium, $\mathrm{HBO}$ vervoer en logistiek, en WO theologie.

Tot slot van deze paragraaf wordt de verwachte vervangingsvraag tot 2016 naar opleidingscategorie afgezet tegen de gerealiseerde vervangingsvraag in het recente verleden. Figuur 2.4 vergelijkt derhalve de geprognosticeerde vervangingsvraag naar opleidingscategorie tot 2016 met de waargenomen vervangingsvraag in de afgelopen jaren. De totale vervangingsvraag zal naar verwachting toenemen van gemiddeld jaarlijks 2,5\% naar $3,7 \%$. Uit de figuur blijkt duidelijk dat de verwachte toekomstige vervangingsvraag in de komende jaren voor vrijwel elke opleidingscategorie hoger ligt dan de gerealiseerde vervangingsvraag in de voorbije periode. Alleen voor ongeschoolden (basisonderwijs) zal de verwachte vervangingsvraag waarschijnlijk lager uitvallen dan de gerealiseerde vervangingsvraag tussen 2006 en 20IO. De grootste toename ten opzichte van de realisaties wordt verwacht voor $\mathrm{HBO}$ onderwijs en WO medisch, maar ook voor andere $\mathrm{HBO}$ - en WO-opleidingscategorieën wordt een flinke stijging van de vervangingsvraag verwacht. Dit wijst erop dat de vervangingsvraag vooral zal stijgen voor de hoger opgeleiden, terwijl deze minder dan gemiddeld zal stijgen voor de meeste lagere opleidingscategorieën, waarvoor de stijging al eerder heeft plaatsgevonden. Dit wordt in belangrijke mate veroorzaakt door de groep hoogopgeleide babyboomers die vaak tot hun 65e aan het werk blijven. Zij gaan dus op latere leeftijd met pensioen en dit resulteert pas nu in een aanzienlijke stijging van de vervangingsvraag. 


\section{Figuur 2.4}

Vervangingsvraag naar opleidingscategorie, prognose 2011-2016 en realisatie 2006-2010 als gemiddeld jaarlijks percentage van de werkgelegenheid in het basisjaar

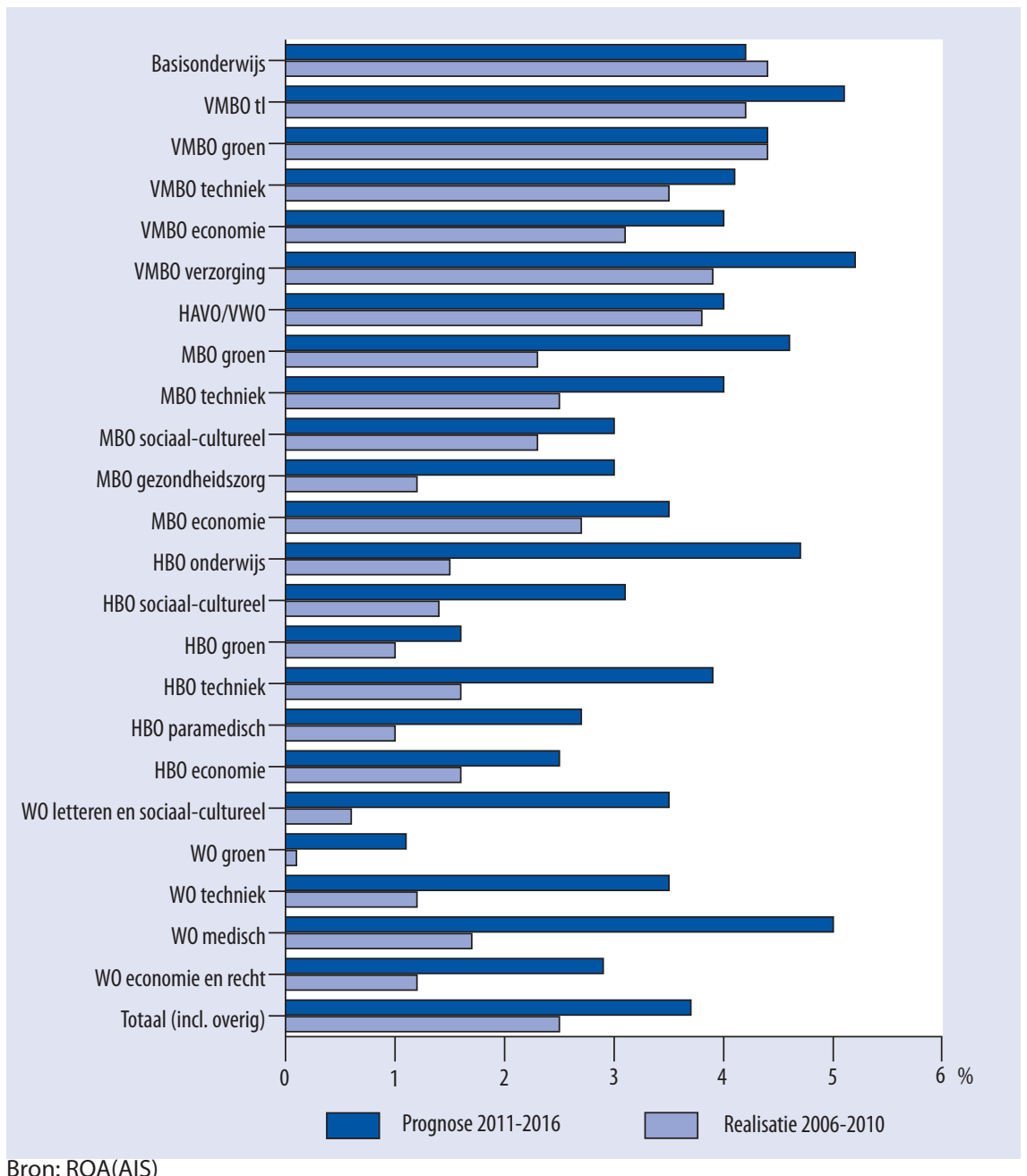

\subsection{Baanopeningen}

De totale vraag naar nieuwkomers op de arbeidsmarkt wordt uitgedrukt in het aantal baanopeningen. Het totaal aantal baanopeningen geeft de vrijkomende banen weer per beroepsklasse of opleidingscategorie die beschikbaar komen voor nieuwe medewerkers. Het aantal baanopeningen is een optelsom van de uitbreidingsvraag (wanneer 
ze positief uitpakt) en de vervangingsvraag. 55 Indien de prognoses voor een bepaalde beroepsklasse of opleidingscategorie wijzen op een krimpende werkgelegenheid, i.e. wanneer er sprake is van negatieve uitbreidingsvraag, dan bestaan de baanopeningen enkel uit vervangingsvraag. Bij de berekening van de vervangingsvraag is namelijk al rekening gehouden met een daling van de werkgelegenheid.

\section{Beroepen}

Tabel 2.8 laat de prognoses voor het aantal baanopeningen per beroepsklasse zien. Naast de totale vraag naar arbeidskrachten blijkt tevens uit de tabel welk deel van de baanopeningen bestaat uit vervangingsvraag. In de zesjaarsperiode tot 2016 zullen er naar verwachting ruim 2,4 miljoen baanopeningen ontstaan. Het totaal aantal baanopeningen, gemeten als het gemiddeld jaarlijks percentage van de werkgelegenheid in 20Io, bedraagt 4,9\%. Ruim 8 op de io baanopeningen ontstaan als gevolg van vervangingsvraag, het overige deel bestaat uit uitbreidingsvraag.

\section{Tabel 2.8}

Baanopeningen naar beroepsklasse, in aantal en als percentage van de werkgelegenheid in 2010, prognose 2011-2016

\begin{tabular}{lcccc}
\hline Beroepsklasse & Aantal & Totaal (6 jr.) & Gem. jaarlijks & $\begin{array}{c}\text { Belang } \\
\text { vervangingsvraag } \\
\%\end{array}$ \\
\hline Pedagogische beroepen & & $\%$ & $\%$ & 96 \\
\hline Creatieve beroepen & 148.000 & 35 & 4,2 & 100 \\
\hline Agrarische beroepen & 50.800 & 33 & 4,9 & 100 \\
\hline Technische en industrieberoepen & 113.500 & 52 & 7,2 & 94 \\
\hline Transportberoepen & 472.100 & 37 & 5,3 & 99 \\
\hline Medische en paramedische beroepen & 148.900 & 37 & 5,4 & 59 \\
\hline Economisch-administratieve beroepen & 208.400 & 43 & 6,1 & 91 \\
\hline Informaticaberoepen & 554.100 & 26 & 4,0 & 92 \\
\hline Sociaal-culturele beroepen & 51.600 & 18 & 2,8 & 88 \\
\hline Verzorgende en dienstverlenende beroepen & 72.600 & 22 & 3,4 & 62 \\
\hline Openbare orde- en veiligheidsberoepen & 500.800 & 38 & 5,5 & 91 \\
\hline Totaal (incl. overig) & 27.100 & 23 & 3,6 & 84 \\
\hline Bron: ROA (AIS) & & & & 4,9 \\
\hline
\end{tabular}

Het aantal baanopeningen zal jaarlijks relatief gezien het meest toenemen bij de agrarische beroepen en de medische en paramedische beroepen. Waar bij de agrarische beroepen het totaal aantal baanopeningen verklaard wordt uit vervangingsvraag in

55. Deze vaststelling van het aantal baanopeningen vindt plaats op het laagste aggregatieniveau (zie Bijlage B) van beroepsgroepen (binnen een beroepsklasse) en opleidingstypen (binnen een opleidingscategorie). Hierdoor leidt een optelling van de in dit hoofdstuk gepresenteerde uitbreidingsvraag en vervangingsvraag op het hogere aggregatieniveau van beroepsklassen en opleidingscategorieën niet vanzelf tot het correcte percentage baanopeningen per beroepsklasse of opleidingscategorie. 
verband met een hoge gemiddelde leeftijd van de werkenden, daar blijkt voor de medische en paramedische beroepen dat 'slechts' zes op de tien baanopeningen door vervangingsvraag worden veroorzaakt. Zoals eerder aan bod kwam, speelt in deze beroepsklasse de positieve uitbreidingsvraag eveneens een belangrijke rol. Bij de informaticaberoepen, sociaal-culturele beroepen en de openbare orde- en veiligheidsberoepen is het gemiddelde jaarlijkse aantal baanopeningen als percentage van de werkgelegenheid het kleinst. Verder blijkt uit de tabel dat het aantal baanopeningen in de meeste beroepsklassen, maar met name bij de pedagogische beroepen, creatieve beroepen, agrarische beroepen en transportberoepen, (vrijwel) volledig is toe te schrijven aan vervangingsvraag. Alleen bij de medische en paramedische beroepen en de verzorgende en dienstverlenende beroepen bestaat een aanzienlijk deel van de baanopeningen uit uitbreidingsvraag. Dit waren volgens tabel 2.I ook de enige twee beroepsklassen met een positieve uitbreidingsvraag in de periode tot 2016.

\section{Figuur 2.5}

Baanopeningen naar beroepsklasse, prognose 2011-2016 en realisatie 2006-2010, als gemiddeld jaarlijks percentage van de werkgelegenheid in het basisjaar

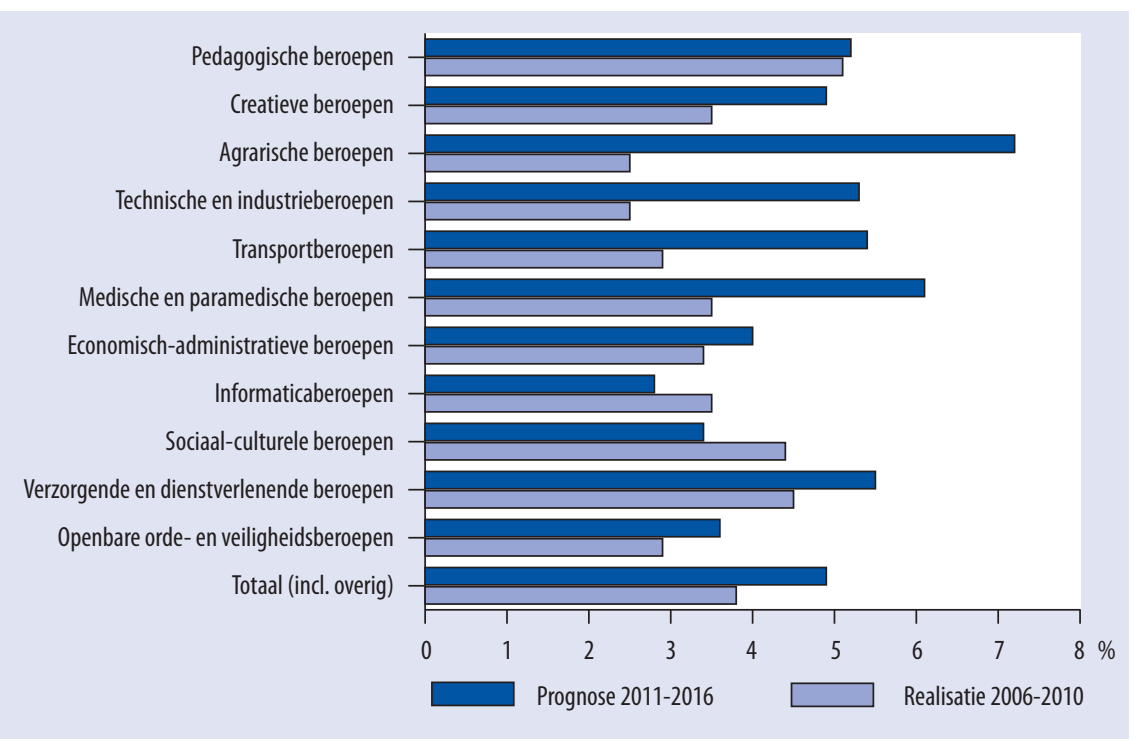

Bron: $\operatorname{ROA}(\mathrm{AIS})$

In figuur 2.5 worden de prognoses voor de verwachte baanopeningen tot 2016 vergeleken met de gerealiseerde baanopeningen tussen 2006 en 20IO. Zo wordt voor elke beroepsklasse duidelijk of de prognoses in lijn zijn met de trend die de voorbije jaren was ingezet wat betreft de ontwikkeling van het aantal gevraagde nieuwe instromers. Het totaal aantal baanopeningen zal met gemiddeld jaarlijks 4,9\% van de werkgelegenheid de komende jaren naar verwachting hoger zijn dan het percentage van 3,8\% in de voorbije jaren. Afgezien van de informaticaberoepen en de sociaal-culturele beroepen, 
waar het aantal baanopeningen de komende jaren zal afnemen, laten de prognoses voor de verschillende beroepsklassen een stijgende lijn zien ten opzichte van de gerealiseerde baanopeningen tussen 2006 en 20IO. In vergelijking met de voorbije periode zal het aantal baanopeningen als percentage van de werkgelegenheid vooral toenemen in de technische en industrieberoepen, transportberoepen, medische en paramedische beroepen en in het bijzonder de agrarische beroepen.

\section{Opleidingen}

De totale vraag naar instromers op de arbeidsmarkt kan eveneens gespecificeerd worden naar opleiding. Tabel 2.9 laat per opleidingscategorie zien hoeveel baanopeningen er ontstaan in de periode 20II-20I6. Bovendien wordt weergegeven in welke mate deze nieuwe baanopeningen een gevolg zijn van vervangingsvraag. Het resterende, niet in de tabel weergegeven deel bestaat uit uitbreidingsvraag. Het totaal aantal baanopeningen, gemeten als het gemiddeld jaarlijks percentage van de werkgelegenheid in 20IO, bedraagt 4,I\%. Van het totaal aantal baanopeningen is nagenoeg negen op de tien het gevolg van vervangingsvraag.

Het percentage baanopeningen bij de lager en middelbaar opgeleiden is vaak bovengemiddeld, terwijl voor verschillende opleidingscategorieën in het hoger beroepsonderwijs en het wetenschappelijk onderwijs een lager dan gemiddeld percentage baanopeningen verwacht wordt. Verder blijkt op alle niveaus de vraag groot voor arbeidskrachten met een diploma in de zorg. De opleidingscategorieën met een relatief hoog percentage baanopeningen in de komende jaren zijn VMBO tl, VMBO verzorging en vooral WO medisch. Voor met name $\mathrm{HBO}$ groen en WO groen, maar ook voor $\mathrm{HBO}$ economie en WO economie en recht worden juist relatief weinig baanopeningen verwacht. Op alle opleidingsniveaus is bij de zorgopleidingen het belang van de vervangingsvraag in de baanopeningen relatief laag. Hetzelfde geldt voor MBO sociaal-cultureel en WO groen.

Om het in de toekomst verwachte aantal baanopeningen te kunnen vergelijken met het beeld in de afgelopen vijf jaar, worden beide tegen elkaar afgezet in figuur 2.6. Zo wordt duidelijk of het verwachte aantal baanopeningen per opleidingscategorie afwijkt van de trend die de afgelopen jaren is waargenomen. Uit de figuur blijkt dat het verwachte gemiddelde jaarlijkse percentage baanopeningen in de komende periode iets lager zal zijn dan in de afgelopen periode, namelijk 4,I\% tegenover 4,4\%. Het aantal opleidingscategorieën waarvoor een afname van de baanopeningen wordt verwacht is vrijwel gelijk aan het aantal categorieën waarvoor een toename verwacht wordt ten opzichte van de voorbije periode.

Bij de lager opgeleiden zal de totale vraag naar nieuwkomers op de arbeidsmarkt de komende jaren vooral toenemen voor $\mathrm{VMBO}$ verzorging. Bij de middelbaar opgeleiden neemt het aantal baanopeningen met name toe voor $\mathrm{MBO}$ groen, terwijl de sterkste afname ten opzichte van de afgelopen vijf jaar verwacht wordt voor $\mathrm{MBO}$ 
sociaal-cultureel. Onder de hoger opgeleiden is het algemene beeld dat het percentage baanopeningen zal afnemen in vergelijking met de vorige periode. Dit geldt in het bijzonder voor $\mathrm{HBO}$ sociaal-cultureel, WO letteren en sociaal-cultureel en WO economie en recht. Daar staat tegenover dat er juist een toename van het percentage baanopeningen verwacht wordt voor $\mathrm{HBO}$ onderwijs, WO groen en WO medisch.

Tabel 2.9

Baanopeningen naar opleidingscategorie, in aantal en als percentage van de werkgelegenheid in 2010, prognose 2011-2016

\begin{tabular}{|c|c|c|c|c|}
\hline Opleidingscategorie & Aantal & $\begin{array}{c}\text { Totaal (6 jr.) } \\
\\
\%\end{array}$ & $\begin{array}{c}\text { Gem. jaarlijks } \\
\%\end{array}$ & $\begin{array}{c}\text { Belang } \\
\text { vervangingsvraag } \\
\%\end{array}$ \\
\hline Basisonderwijs & 98.700 & 29 & 4,4 & 94 \\
\hline VMBO tl & 165.000 & 36 & 5,2 & 98 \\
\hline VMBO groen & 15.700 & 29 & 4,4 & 100 \\
\hline VMBO techniek & 106.200 & 27 & 4,1 & 100 \\
\hline VMBO economie & 44.500 & 28 & 4,2 & 94 \\
\hline VMBO verzorging & 69.900 & 42 & 6,0 & 84 \\
\hline HAVO/VWO & 173.900 & 29 & 4,3 & 92 \\
\hline MBO groen & 43.500 & 31 & 4,6 & 100 \\
\hline MBO techniek & 221.400 & 28 & 4,2 & 96 \\
\hline MBO sociaal-cultureel & 165.600 & 31 & 4,6 & 63 \\
\hline MB0 gezondheidszorg & 65.500 & 32 & 4,7 & 61 \\
\hline MBO economie & 188.200 & 24 & 3,7 & 95 \\
\hline $\mathrm{HBO}$ onderwijs & 105.200 & 32 & 4,7 & 99 \\
\hline HBO sociaal-cultureel & 86.100 & 23 & 3,5 & 88 \\
\hline HBO groen & 3.900 & 11 & 1,7 & 90 \\
\hline HBO techniek & 74.700 & 27 & 4,1 & 95 \\
\hline HBO paramedisch & 55.900 & 30 & 4,5 & 58 \\
\hline $\mathrm{HBO}$ economie & 70.800 & 17 & 2,7 & 95 \\
\hline WO letteren en sociaal-cultureel & 70.900 & 26 & 4,0 & 88 \\
\hline W0 groen & 1.900 & 12 & 1,9 & 58 \\
\hline WO techniek & 40.100 & 26 & 3,9 & 89 \\
\hline WO medisch & 39.100 & 52 & 7,2 & 66 \\
\hline W0 economie en recht & 50.800 & 20 & 3,1 & 91 \\
\hline $\begin{array}{c}\text { Totaal (incl. overig) } \\
\text { Bron: ROA (AIS) }\end{array}$ & 2.019 .300 & 27 & 4,1 & 89 \\
\hline
\end{tabular}




\section{Figuur 2.6}

Baanopeningen naar opleidingscategorie, prognose 2011-2016 en realisatie 2006-2010, als gemiddeld jaarlijks percentage van de werkgelegenheid in het basisjaar

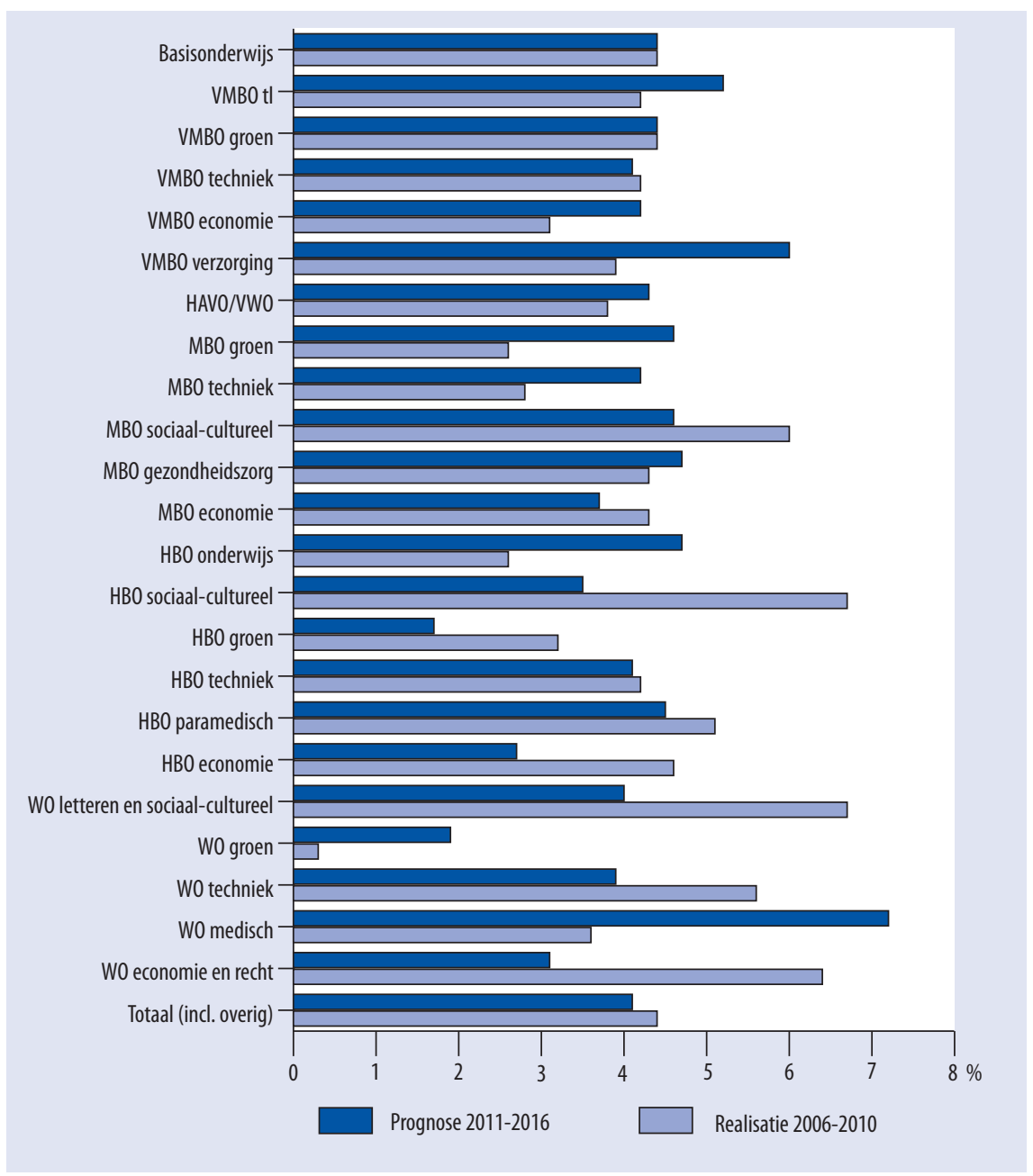

Bron: ROA(AIS)

\subsection{Arbeidsmarktinstroom}

Tot dusverre is in dit hoofdstuk enkel de vraag naar arbeid aan bod gekomen. Om echter gefundeerde uitspraken te kunnen doen over de arbeidsmarktperspectieven van schoolverlaters moeten ontwikkelingen op het gebied van de vraag naar arbeid gecombineerd worden met het aanbod van arbeid. In deze paragraaf wordt de aanbodzijde besproken. De grootste en belangrijkste component wat betreft het arbeidsmarkt- 
aanbod bestaat uit de verwachte arbeidsmarktinstroom van schoolverlaters die het initiële onderwijs verruilen voor de arbeidsmarkt. Een andere belangrijke component van het arbeidsmarktaanbod wordt gevormd door reeds werkenden die door middel van om- of bijscholing een diploma behalen dat hun opleidingsniveau verhoogt of hun opleidingsrichting verandert. Doordat zij hun kwalificatieprofiel dusdanig veranderen kunnen deze werkenden die doorleren als nieuw aanbod op de arbeidsmarkt gezien worden. ${ }^{56}$

In de periode tot 2016 zullen er naar verwachting in totaal I.695.000 arbeidskrachten op de arbeidsmarkt instromen. Dit betekent dat er een gemiddelde jaarlijkse arbeidsmarktinstroom van 3,5\% van de werkgelegenheid in 2010 verwacht wordt. Er zal in de komende jaren relatief weinig arbeidsmarktinstroom zijn voor de meeste technische en groene opleidingen (VMBO groen uitgezonderd). De arbeidsmarktinstroom van arbeidskrachten met een diploma economie is op de meeste opleidingsniveaus juist vrij groot.

Het aanbod van lager opgeleiden dat beschikbaar komt op de arbeidsmarkt laat per opleidingscategorie uiteenlopende resultaten zien. Terwijl de verwachte arbeidsmarktinstroom als percentage van de werkgelegenheid hoog is voor ongeschoolden, VMBO groen en $\mathrm{VMBO}$ economie, is de verwachte arbeidsmarktinstroom voor $\mathrm{VMBO} \mathrm{tl}$ en $\mathrm{VMBO}$ techniek juist erg laag. Binnen VMBO techniek is de verwachte instroom laag voor alle onderliggende opleidingstypen, uitgezonderd VMBO grafische techniek met een arbeidsmarktinstroom van gemiddeld jaarlijks 3,3\% van de werkgelegenheid. Er wordt de komende jaren met name weinig instroom verwacht van personen met een VMBO-diploma installatie-, metaal- of elektrotechniek.

De arbeidsmarktinstroom van schoolverlaters met een HAVO- of VWO-diploma is bovengemiddeld. Dit zijn vaak drop-outs van het hoger onderwijs die vaak tijdelijk gaan werken om daarna met een nieuwe studie te beginnen. Bij de middelbare beroepsopleidingen wordt er een grote arbeidsmarktinstroom verwacht voor $\mathrm{MBO}$ sociaalcultureel, en een lage instroom voor $\mathrm{MBO}$ groen. Hoewel de arbeidsmarktinstroom als percentage van de werkgelegenheid voor $\mathrm{MBO}$ techniek min of meer gemiddeld is, laten de onderliggende opleidingstypen grote verschillen zien. De instroom varieert van gemiddeld jaarlijks I, $8 \%$ voor $\mathrm{MBO}$ fijnmechanische techniek en $\mathrm{MBO}$ werktuigbouw en mechanische techniek, tot $6,0 \%$ voor $\mathrm{MBO}$ installatietechniek, $6,4 \%$ voor $\mathrm{MBO}$ vervoer en $6,5 \%$ voor $\mathrm{MBO}$ operationele techniek. $\mathrm{MBO}$ techniek is echter niet de enige opleidingscategorie met flinke uitschieters bij de onderliggende opleidingstypen. Zo springt binnen $\mathrm{MBO}$ sociaal-cultureel de verwachte arbeidsmarktinstroom van $\mathrm{MBO}$ sociaal-pedagogisch en welzijn met gemiddeld jaarlijks 6,I\% van de werkgelegenheid er duidelijk uit. Bij MBO gezondheidszorg loopt de verwachte instroom uiteen van gemiddeld jaarlijks 2,7\% voor de $\mathrm{MBO}$-opleidingen tot apothekersassistent tot zelfs $7,3 \%$ voor beweging en therapie. Binnen $\mathrm{MBO}$ economie is de

56. Dat betekent dat voor de voormalige opleiding vervangingsvraag ontstaat. Zie paragraaf 2.3. 
arbeidsmarktinstroom hoog voor $\mathrm{MBO}$ toerisme en recreatie en MBO ICT wat blijkt uit de instroompercentages van respectievelijk gemiddeld jaarlijks 5,9\% en 6,7\%.

\section{Tabel 2.10}

Instroom op de arbeidsmarkt naar opleidingscategorie, in aantal en als percentage van de werkgelegenheid in 2010, prognose 2011-2016

\begin{tabular}{|c|c|c|c|}
\hline Opleidingscategorie & Aantal & $\begin{array}{c}\text { Totaal (6 jr.) } \\
\%\end{array}$ & $\begin{array}{c}\text { Gem. jaarlijks } \\
\%\end{array}$ \\
\hline Basisonderwijs & 150.000 & 44 & 6,3 \\
\hline VMBO tl & 52.300 & 11 & 1,8 \\
\hline VMBO groen & 18.700 & 35 & 5,1 \\
\hline VMBO techniek & 44.400 & 11 & 1,8 \\
\hline VMBO economie & 45.800 & 29 & 4,3 \\
\hline VMBO verzorging & 32.500 & 20 & 3,0 \\
\hline HAVO/VWO & 185.600 & 30 & 4,5 \\
\hline MBO groen & 24.000 & 17 & 2,6 \\
\hline MBO techniek & 163.300 & 20 & 3,2 \\
\hline MBO sociaal-cultureel & 178.300 & 34 & 4,9 \\
\hline MBO gezondheidszorg & 52.100 & 25 & 3,8 \\
\hline MBO economie & 206.100 & 26 & 4,0 \\
\hline $\mathrm{HBO}$ onderwijs & 49.100 & 14 & 2,2 \\
\hline HBO sociaal-cultureel & 92.700 & 26 & 3,9 \\
\hline HBO groen & 4.700 & 13 & 2,1 \\
\hline HBO techniek & 49.600 & 18 & 2,8 \\
\hline HBO paramedisch & 35.600 & 19 & 3,0 \\
\hline HBO economie & 96.800 & 23 & 3,5 \\
\hline W0 letteren en sociaal-cultureel & 59.300 & 22 & 3,3 \\
\hline W0 groen & 3.000 & 20 & 3,1 \\
\hline W0 techniek & 29.700 & 19 & 2,9 \\
\hline W0 medisch & 21.500 & 29 & 4,3 \\
\hline W0 economie en recht & 70.000 & 28 & 4,2 \\
\hline $\begin{array}{l}\text { Totaal (incl. overig) } \\
\text { Bron. }\end{array}$ & 1.695 .000 & 23 & 3,5 \\
\hline
\end{tabular}

Bron: ROA (AIS)

De arbeidsmarktinstroom van hoger opgeleiden is in veel gevallen lager dan gemiddeld. Alleen voor HBO sociaal-cultureel, WO economie en recht en WO medisch wordt een bovengemiddeld hoge arbeidsmarktinstroom verwacht. Er zullen daarentegen verhoudingsgewijs weinig afgestudeerden van $\mathrm{HBO}$ groen en $\mathrm{HBO}$ onderwijs de arbeidsmarkt betreden. Hoewel de instroom voor nagenoeg alle opleidingen op $\mathrm{HBO}$-niveau vrij laag is, kan dit niet gezegd worden voor de $\mathrm{HBO}$ lerarenopleidingen lichamelijke opvoeding met een arbeidsmarktinstroom van gemiddeld jaarlijks 5,6\% van de werkgelegenheid. Binnen $\mathrm{HBO}$ sociaal-cultureel schieten er twee opleidingstypen bovenuit. De opleidingen HBO tolk en vertaler blijken niet meer populair, zoals kan worden afgeleid uit het erg lage instroompercentage van gemiddeld jaarlijks $0,5 \%$. Daar staat tegenover dat de instroom van HBO horeca met gemiddeld jaar- 
lijks 7,5\% heel hoog is. Binnen WO economie en recht valt het opleidingstype WO bedrijfskunde op door de relatief hoge verwachte arbeidsmarktinstroom van gemiddeld jaarlijks 5,6\% van de werkgelegenheid.

\section{Figuur 2.7}

Arbeidsmarktinstroom naar opleidingscategorie, prognose 2011-2016 en realisatie 2006-2010 als gemiddeld jaarlijks percentage van de werkgelegenheid in het basisjaar

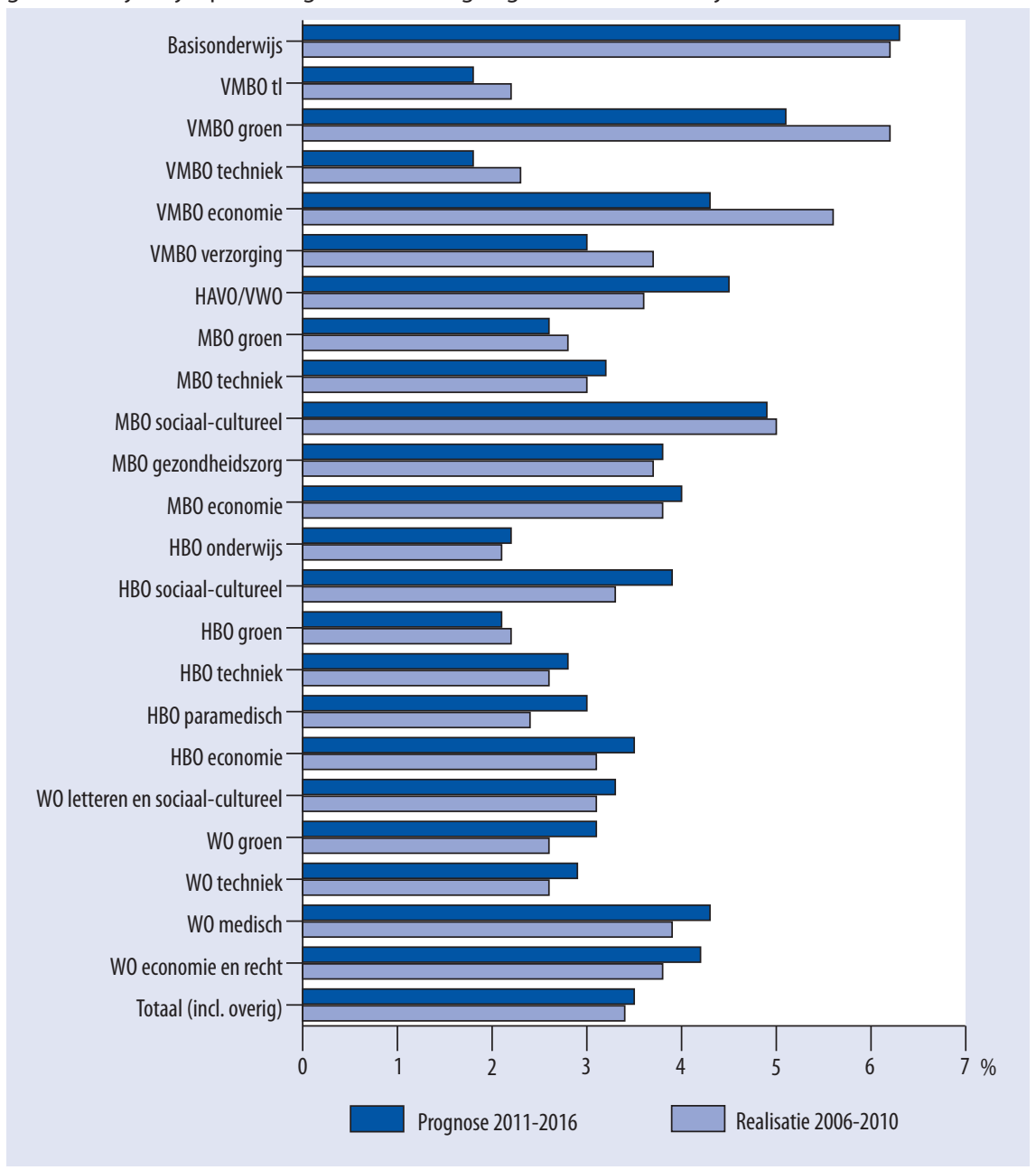

Bron: $\operatorname{ROA}(\mathrm{AIS})$

De prognoses voor de verwachte totale arbeidsmarktinstroom laten een lichte toename zien van $3,4 \%$ in de periode $2006-2010$ tot $3,5 \%$ in de periode $201 \mathrm{II}-20 \mathrm{O} 6$. Deze lichte toename wordt zeker niet veroorzaakt door de lagere opleidingen. Met uitzondering van de ongeschoolden waar een lichte stijging verwacht wordt, zal de instroom in elke opleidingscategorie op VMBO-niveau dalen ten opzichte van de gerealiseerde instroom in de voorbije periode. Vooral voor gediplomeerden van VMBO groen en 
VMBO economie zal de instroom naar verwachting afnemen in vergelijking met de waargenomen arbeidsmarktinstroom van de afgelopen vijf jaar. Van alle 23 onderscheiden opleidingscategorieën zal het relatieve aantal Havisten en VWO'ers die de arbeidsmarkt betreden met $0,9 \%$-punt het meest toenemen ten opzichte van de periode 2006-20I0. De instroom van middelbaar opgeleiden zal naar verwachting niet veel afwijken van de arbeidsmarktinstroom in de afgelopen jaren. Wel stijgt de verwachte instroom van hoger opgeleiden iets in vergelijking met de voorbije periode. Het aantal afgestudeerden van $\mathrm{HBO}$ sociaal-cultureel zal daarbij het meest stijgen (o,6\%-punt). Alleen voor $\mathrm{HBO}$ groen wordt er, evenals op VMBO- en MBO-niveau, een daling van het aantal instromers verwacht (-o,I\%-punt).

\subsection{Conclusies}

De verwachte gemiddelde jaarlijkse uitbreidingsvraag tot 2016 is $0,4 \%$, maar deze lichte groei wordt in zijn geheel veroorzaakt door de positieve uitbreidingsvraag in slechts 2 van de II beroepsklassen: de medische en paramedische beroepen alsook de verzorgende en dienstverlenende beroepen. De uitbreidingsvraag in deze beroepsklassen wordt in belangrijke mate veroorzaakt door de vergrijzing en de daarmee samenhangende toenemende behoefte aan zorg. Ook bij de uitbreidingsvraagprognoses naar opleiding springt de verwachte toename van de werkgelegenheid voor gediplomeerden van zorgopleidingen het meest in het oog. Eventuele bezuinigingen in de zorgsector kunnen de verwachte groei van de werkgelegenheid nog in de weg staan. Voor MBO sociaal-cultureel is de uitbreidingsvraag eveneens erg hoog. De werkgelegenheid krimpt procentueel gezien het sterkst bij de groene opleidingen op zowel VMBO- als MBO-niveau en bij $\mathrm{HBO}$ onderwijs.

Een andere belangrijke vraagcomponent in het prognosemodel is de vervangingsvraag. In de prognoseperiode $201 \mathrm{I}-2 \mathrm{OI} 6$ moeten in totaal ruim 2 miljoen arbeidskrachten vervangen worden. Ten opzichte van het werkgelegenheidsniveau in basisjaar 2010 komt dit neer op een gemiddelde jaarlijkse vervangingsvraag naar beroep van 4,I\%. De vervangingsvraag zal de komende jaren vooral hoog zijn in de transportberoepen en de sterk vergrijsde agrarische beroepen. In de informaticaberoepen is de vervangingsvraag daarentegen het laagst van alle beroepsklassen.

Daarnaast is een gedachte-experiment uitgevoerd waarin voor de verschillende beroepsgroepen bekeken is wat het effect op de vervangingsvraag is als de pensioenleeftijd met twee jaar zou worden verhoogd, bijvoorbeeld door de pensioengerechtigde leeftijd meteen op 67 jaar vast te stellen. Doordat er langer wordt doorgewerkt, dringt deze maatregel de totale vervangingsvraag naar beroep terug van gemiddeld jaarlijks 4,I\% van de werkgelegenheid naar 3,I\%. Deze maatregel heeft echter niet in alle beroepsklassen een even groot effect. In de transportberoepen en de agrarische beroepen is relatief gezien de grootste winst te boeken, doordat er in deze beroepsklassen veel ouderen werkzaam zijn. Bij de onderliggende beroepsgroepen heeft uitstel 
van de pensioenleeftijd met het oog op het terugdringen van de arbeidstekorten om diezelfde reden vooral een groot effect voor conciërges, agrarische bedrijfshoofden en geestelijk verzorgers. Voorbeelden van beroepsgroepen waar deze maatregel niet of nauwelijks effectief is, zijn elektrotechnici, stewards, zweminstructeurs en vakkenvullers.

De prognoses voor de vervangingsvraag naar opleiding laten zien dat tot 2016 gemiddeld jaarlijks 3,7\% van het totaal aantal werkenden vervangen moet worden. In lijn met de verwachtingen is de vervangingsvraag het hoogst voor de lager opgeleiden door het doorleereffect. Ten opzichte van de periode 2006-20IO worden echter de grootste toenames verwacht in de vervangingsvraag voor hoger opgeleiden. Dit geldt in het bijzonder voor $\mathrm{HBO}$ onderwijs en WO medisch.

In de periode 20II-20I6 zullen er volgens de prognoses ruim 2,4 miljoen baanopeningen naar beroep ontstaan. Uitgaande van de werkgelegenheid in het basisjaar 2010 bedraagt het gemiddelde jaarlijkse aantal baanopeningen 4,9\%. Ruim 8 op de io van deze baanopeningen ontstaan als gevolg van vervangingsvraag, terwijl het overige deel ontstaat uit uitbreidingsvraag. Het aantal baanopeningen zal het meest toenemen bij de agrarische beroepen en de medische en paramedische beroepen. Op alle opleidingsniveaus ontstaan veel baanopeningen voor arbeidskrachten met een diploma in de zorg. Voor HBO groen en WO groen, maar ook voor HBO economie en WO economie en recht, worden juist weinig baanopeningen verwacht.

In de periode tot 2016 zullen er in totaal I.695.000 schoolverlaters instromen op de arbeidsmarkt. Dit betekent een gemiddelde jaarlijkse instroom van 3,5\% van de werkgelegenheid in 20IO. Er zal in de komende jaren relatief weinig arbeidsmarktinstroom zijn voor de meeste technische en groene opleidingen. De instroom van schoolverlaters met een diploma economie is op de meeste opleidingsniveaus juist relatief groot. De relatief gezien grootste instroom wordt de komende jaren verwacht voor ongeschoolden, $\mathrm{VMBO}$ groen en $\mathrm{MBO}$ sociaal-cultureel, terwijl er voor $\mathrm{VMBO} \mathrm{tl}$, VMBO techniek, $\mathrm{HBO}$ onderwijs en $\mathrm{HBO}$ groen juist relatief weinig nieuwkomers op de arbeidsmarkt bijkomen. 



\section{Aansluiting tussen onderwijs en arbeidsmarkt}

\subsection{Inleiding}

In hoofdstuk 3 komt de aansluiting tussen onderwijs en arbeidsmarkt voor schoolverlaters aan bod. In paragraaf 3.2 wordt de arbeidsmarktsituatie van deze schoolverlaters in 2010 uitgebreid besproken aan de hand van verschillende aansluitingsindicatoren. Werkloosheid en beloning zijn hiervan de meest gangbare, maar zeker niet de enige, indicatoren die iets zeggen over de arbeidsmarktpositie van schoolverlaters. Andere indicatoren zijn bijvoorbeeld het verrichten van werk onder het behaalde opleidingsniveau of buiten de eigen vakrichting, maar ook het werken in een tijdelijke aanstelling. Bovendien wordt de arbeidsmarktsituatie van schoolverlaters in 2010 vergeleken met 2006.57 Zoals zal blijken is hun situatie op de arbeidsmarkt, gemeten anderhalf jaar na het afronden van de opleiding, in deze periode minder gunstig geworden. Paragraaf 3.3 bespreekt vervolgens de toekomstige ontwikkelingen aangaande de arbeidsmarktpositie van schoolverlaters. In deze paragraaf wordt aandacht besteed aan de toekomstperspectieven voor schoolverlaters in de prognoseperiode 20II-20I6 voor de 23 verschillende opleidingscategorieën. Deze toekomstperspectieven worden afgeleid van de confrontatie tussen de verwachte vraag- en aanbodontwikkelingen op de arbeidsmarkt die in hoofdstuk 2 aan bod zijn gekomen. Deze vraag- en aanbodontwikkelingen beïnvloeden niet alleen de toekomstperspectieven van schoolverlaters, maar ook de verwachte knelpunten in de personeelsvoorziening voor werkgevers. In paragraaf 3.4 wordt voor de verschillende beroepsklassen ingegaan op de beloning en loonontwikkeling. Vervolgens wordt in paragraaf 3.5 dieper ingegaan op de beroepsgroepen waarvoor werkgevers in de periode tot 2016 de grootste knelpunten in de personeelsvoorziening kunnen verwachten.

57. De in dit hoofdstuk gepresenteerde cijfers voor afgestudeerden van het WO hebben betrekking op 2009, tenzij anders weergegeven. De afgestudeerdenenquête voor het WO wordt in tegenstelling tot de andere enquêtes nog slechts om het jaar gehouden. 


\subsection{Huidige aansluitingsproblemen}

In paragraaf 3.2 wordt de arbeidsmarktsituatie van schoolverlaters in 2010 in kaart gebracht aan de hand van verschillende indicatoren. De indicatoren die voor schoolverlaters van de verschillende opleidingscategorieën besproken worden zijn achtereenvolgens het werkloosheidspercentage, de beloning, onderbenutting, buiten het eigen vakgebied werkenden, deeltijdbanen, flexibele banen, en spijt van de eerder gevolgde opleiding. Hierbij wordt gebruik gemaakt van schoolverlatersgegevens afkomstig van het SchoolverlatersInformatieSysteem (SIS) van het ROA..$^{8}$ Deze data zijn afkomstig van vragenlijsten die gediplomeerden circa anderhalf jaar na het afronden van hun opleiding hebben ingevuld. De schoolverlaters die deze vragenlijsten eind 2010 hebben ingevuld kwamen in 2009 beschikbaar voor de arbeidsmarkt. Om deze indicatoren te kunnen vergelijken met de arbeidsmarktsituatie van schoolverlaters in 2006, worden beide cijfers telkens tegen elkaar afgezet. Het gaat hier dus om gegevens die betrekking hebben op schoolverlaters van studiejaar 2008/2009 die vergeleken worden met degenen van 2004/2005. Dit is belangrijk met het oog op de interpretatie van de resultaten, want dit betekent dat de aansluitingsindicatoren vergeleken worden met de periode vóór de economische crisis.

\section{Werkloosheid}

Het werkloosheidspercentage onder recente schoolverlaters geeft een goede indicatie over de arbeidsmarktintrede van gediplomeerden van de verschillende opleidingscategorieën. Tabel 3.I laat het percentage van de schoolverlaters in de beroepsbevolking zien dat in 2010 werkloos was. De resultaten zijn weergegeven per opleidingscategorie. Tevens wordt de verandering van het werkloosheidspercentage in \%-punt weergegeven ten opzichte van 2006. Zo kunnen recente ontwikkelingen in kaart gebracht worden.

Uit tabel 3.I blijkt dat het werkloosheidspercentage voor de totale groep schoolverlaters $7,9 \%$ bedraagt in $2010 .{ }^{59} \mathrm{Er}$ zijn grote verschillen in werkloosheid tussen de opleidingscategorieën. Schoolverlaters van VMBO techniek en VMBO verzorging vinden doorgaans gemakkelijk een baan. Het gaat hier vaak om contracten in het kader van een leer-werkplek. Onder de schoolverlaters van VMBO economie die zich aanbieden op de arbeidsmarkt is I0,7\% werkloos, en van VMBO tl maar liefst $17,3 \%$. Ook een groot deel van de Havisten en VWO'ers is werkloos. In het algemeen betreedt slechts een klein percentage van de gediplomeerden van het voortgezet onderwijs de arbeidsmarkt, waardoor het hier om kleine aantallen gaat. Het gaat hier deels om drop-outs

58. SIS bestaat uit de VO Monitor voor het voortgezet onderwijs, de BVE Monitor voor het middelbaar beroepsonderwijs, de HBO Monitor voor het hoger beroepsonderwijs en, tot voor kort, de WO Monitor voor het wetenschappelijk onderwijs.

59. De percentages voor de totalen in de tabellen 3.I t/m 3.7 hebben alleen betrekking op schoolverlaters van VMBO, HAVO/VWO, MBO (BOL) en HBO. Het gaat om ongewogen gemiddelden. 
van een vervolgopleiding die ter overbrugging naar een volgend studiejaar tijdelijk werk verrichten.

\section{Tabel 3.1}

Werkloosheidpercentage van schoolverlaters in de beroepsbevolking en mutatie 2006 en 2010, naar opleidingscategorie

\begin{tabular}{|c|c|c|}
\hline & $\begin{array}{c}2010 \\
\%\end{array}$ & Mutatie in \%-punt \\
\hline VMBO tl & 17,3 & 1,2 \\
\hline VMBO groen & 7,7 & 2,4 \\
\hline VMBO techniek & 5,0 & 3,3 \\
\hline VMBO economie & 10,7 & 2,6 \\
\hline VMBO verzorging & 6,7 & $-4,2$ \\
\hline HAVO/VWO & 15,3 & 5,3 \\
\hline MBO groen & 7,7 & 1,5 \\
\hline MBO techniek & 9,0 & 6,4 \\
\hline MBO sociaal-cultureel & 5,5 & $-1,2$ \\
\hline MBO gezondheidszorg & 2,7 & $-3,3$ \\
\hline MBO economie & 11,0 & 1,6 \\
\hline $\mathrm{HBO}$ onderwijs & 4,7 & $-0,9$ \\
\hline HBO sociaal-cultureel & 8,1 & 2,5 \\
\hline HBO groen & 8,8 & 3,4 \\
\hline HBO techniek & 4,7 & 2,4 \\
\hline HBO paramedisch & 2,5 & $-0,3$ \\
\hline HBO economie & 6,3 & 1,5 \\
\hline W0 letteren en sociaal-cultureel & 6,7 & 0,4 \\
\hline W0 groen & 6,9 & $-1,6$ \\
\hline W0 techniek & 4,4 & 2,0 \\
\hline WO medisch & 1,7 & $-1,9$ \\
\hline W0 economie en recht & 6,5 & 4,0 \\
\hline Totaal (excl. W0, incl. overig) & 7,9 & 1,4 \\
\hline
\end{tabular}

Bron: ROA(SIS)

Opmerkingen:

- MBO heeft hier alleen betrekking op de Beroepsopleidende Leerweg (BOL) en niet op de Beroepsbegeleidende Leerweg (BBL, het voormalige leerlingwezen).

- De cijfers voor de opleidingscategorieën op WO-niveau hebben betrekking op 2009. Voor WO is de mutatie van 2009 ten opzichte van 2006 berekend.

Bij de middelbare beroepsopleidingen hebben vooral gediplomeerden van $\mathrm{MBO}$ economie en $\mathrm{MBO}$ techniek moeite om een baan te vinden. Daarentegen is het werkloosheidspercentage voor MBO gezondheidszorg heel laag. Slechts 2,7\% van de schoolverlaters in de beroepsbevolking met een dergelijke opleidingsachtergrond is anderhalf jaar na het afronden van de opleiding werkloos. 
Bij de hoger opgeleiden zijn afgestudeerden van de groene opleidingen op zowel HBOals WO-niveau relatief vaak werkloos. Ook degenen met een opleiding HBO sociaalcultureel zijn vaker dan gemiddeld werkloos. Zowel HBO- als WO-afgestudeerden met een opleiding techniek en in het bijzonder zorg hebben vlak na afstuderen weinig of geen problemen bij het vinden van een baan. Ook onder afgestudeerden van een lerarenopleiding is er weinig werkloosheid.

Voor schoolverlaters van de richting economie lijkt het de moeite te lonen om door te stromen naar het hoger onderwijs. Hoger opgeleiden met een economische opleidingsachtergrond zijn namelijk aanzienlijk minder vaak werkloos dan lager en middelbaar opgeleiden in dezelfde richting. Daarnaast blijken afgestudeerde technici op alle niveaus relatief eenvoudig een baan te vinden na het afronden van hun opleiding, met uitzondering van technici van de middelbare beroepsopleidingen. Onder schoolverlaters met een zorgopleiding is er op alle niveaus nauwelijks werkloosheid.

In vergelijking met 2006 blijkt het in 2010 voor schoolverlaters moeilijker om een baan te vinden bij het betreden van de arbeidsmarkt. De arbeidsmarktpositie van schoolverlaters is gemiddeld genomen verslechterd, vooral door de economische crisis die in 2008 begon. Wel is de arbeidsmarktpositie van schoolverlaters uit de zorg verbeterd. Het percentage werklozen onder gediplomeerden in de zorgrichting is afgenomen op zowel VMBO-, MBO-, HBO- als WO-niveau. Voor schoolverlaters met een opleiding techniek of economie is het werkloosheidspercentage juist op alle opleidingsniveaus toegenomen ten opzichte van 2006. Verder zijn er in 2010 relatief veel werkloze Havisten en VWO'ers bijgekomen. Voor HBO sociaal-cultureel en $\mathrm{HBO}$ groen is het werkloosheidspercentage eveneens flink gestegen ten opzichte van enkele jaren eerder.

\section{Beloning}

Een andere indicator voor de aansluiting tussen onderwijs en arbeidsmarkt is het loon dat starters op de arbeidsmarkt ontvangen. Het loon geeft een directe indicatie van de waarde die door werkgevers wordt toegekend aan de kwalificaties waarover starters beschikken. Daarnaast zullen werkgevers in tijden van arbeidsmarktkrapte eerder geneigd zijn om hogere salarissen te betalen om zo de concurrentie voor te blijven bij de slag om geschikt personeel. Bij een ruime arbeidsmarkt hebben werkgevers daarentegen juist meer keuze bij het aantrekken van personeel en hoeven zij dus minder op basis van salaris te concurreren. Tabel 3.2 presenteert het gemiddelde bruto maandloon van werkzame schoolverlaters in 2010 naar opleidingscategorie. Bovendien wordt de gemiddelde jaarlijkse stijging van het bruto maandloon tussen 2006 en 20 Io weergegeven. Om een reële vergelijking te kunnen maken wordt bij de verandering van het loon gecorrigeerd voor de inflatie. 
met het opleidingsniveau en dit wijst erop dat doorleren de moeite waard is. Wel moet hierbij opgemerkt worden dat in de tabel niet gecontroleerd is voor de leeftijd van de schoolverlaters. De resultaten worden dus deels veroorzaakt doordat jongeren die langer doorstuderen een hoger loon krijgen vanwege hun leeftijd. Bovendien is het minimumjeugdloon gekoppeld aan de leeftijd en daardoor van invloed op beloning, vooral bij VMBO-schoolverlaters.

Op de verschillende opleidingsniveaus kunnen de gemiddelde reële lonen nog aanzienlijk variëren per opleidingsrichting. Zo verdienen schoolverlaters van VMBO techniek ruim 200 euro meer dan schoolverlaters van VMBO economie, mede doordat de laatste groep er ten opzichte van de situatie in 2006 het meest op achteruit is gegaan van alle opleidingscategorieën. Ook het gemiddelde reële loon van VMBO verzorging is fors gedaald. Het zijn de lager opgeleiden die er tussen 2006 en 2010 het meest op achteruit zijn gegaan. Daarentegen zijn de $\mathrm{MBO}$-schoolverlaters er ondanks de economische tegenspoed het meest op vooruitgegaan. Dit geldt in het bijzonder voor $\mathrm{MBO}$ groen en $\mathrm{MBO}$ techniek. Ook op MBO-niveau verdienen degenen met een opleiding economie het minst. Schoolverlaters van $\mathrm{MBO}$ gezondheidszorg doen het hier duidelijk het best qua beloning. Bij de hogere beroepsopleidingen zijn afgestudeerden die een hoog startsalaris willen hebben het best af met een opleiding HBO paramedisch, gevolgd door $\mathrm{HBO}$ techniek. Afgestudeerden van een opleiding $\mathrm{HBO}$ sociaal-cultureel verdienen het minst. Bij de afgestudeerden van het wetenschappelijk onderwijs doen degenen met een diploma WO medisch het kort na afstuderen veruit het best qua salaris, terwijl universitair afgestudeerden van de groene richting vaak minder verdienen dan afgestudeerden op HBO-niveau. De beloning onder afgestudeerden van WO groen is er bovendien het meest op achteruit gegaan ten opzichte van 2006.

Naast de werkloosheid en het salaris van schoolverlaters zijn er verschillende andere indicatoren beschikbaar die een indicatie geven van de aansluiting tussen onderwijs en arbeidsmarkt. Een slechte aansluiting tussen school en werk kan immers niet alleen afgemeten worden aan een hoge werkloosheid of een lage beloning, maar bijvoorbeeld ook aan het feit dat schoolverlaters een baan accepteren die qua niveau lager is dan hun opleidingsniveau of die buiten hun vakgebied is. Schoolverlaters kunnen min of meer noodgedwongen kiezen voor dergelijke 'ontsnappingsroutes' om een situatie van werkloosheid te vermijden. Dit worden ook wel verborgen discrepanties op de arbeidsmarkt genoemd.

\section{Onderbenutting}

Als schoolverlaters een baan hebben die qua niveau lager is dan hun opleidingsniveau wordt gesproken over onderbenutting. Hierbij wordt het door de werkgever minimaal vereiste niveau voor de functie vergeleken met het daadwerkelijke opleidingsniveau van de werkzame schoolverlater. Tabel 3.3 laat voor alle afzonderlijke opleidingscategorieën zien welk deel van de werkzame schoolverlaters in 2010 onder zijn of haar 
niveau werkt. Tevens wordt de procentuele verandering weergegeven ten opzichte van 2006. Zo wordt duidelijk of er sprake is van een stijgende dan wel dalende trend in het percentage onderbenutting per opleidingscategorie. Het aandeel onderbenutting onder schoolverlaters wordt in belangrijke mate bepaald door de conjunctuur en de arbeidsmarktsituatie. Wanneer de arbeidsmarktsituatie verbetert, neemt de onderbenutting af en vice versa.

\section{Tabel 3.3}

Percentage onderbenutting bij werkzame schoolverlaters en mutatie tussen 2006 en 2010, naar opleidingscategorie

\begin{tabular}{|c|c|c|}
\hline & $\begin{array}{c}2010 \\
\%\end{array}$ & Mutatie in \%-punt \\
\hline VMBO tl & 12,5 & 0,0 \\
\hline VMBO groen & 7,3 & $-10,6$ \\
\hline VMBO techniek & 6,1 & $-3,5$ \\
\hline VMBO economie & 9,2 & $-13,2$ \\
\hline VMBO verzorging & 11,2 & $-5,3$ \\
\hline HAVO/VWO & 54,0 & 20,1 \\
\hline MB0 groen & 25,9 & $-14,5$ \\
\hline MBO techniek & 17,0 & $-5,4$ \\
\hline MBO sociaal-cultureel & 13,9 & $-7,3$ \\
\hline MB0 gezondheidszorg & 8,2 & $-2,5$ \\
\hline MBO economie & 27,2 & 1,7 \\
\hline $\mathrm{HBO}$ onderwijs & 8,0 & 0,0 \\
\hline HBO sociaal-cultureel & 30,1 & 3,1 \\
\hline $\mathrm{HBO}$ groen & 23,5 & $-0,7$ \\
\hline HBO techniek & 15,0 & 2,9 \\
\hline HBO paramedisch & 18,7 & 0,8 \\
\hline HBO economie & 22,8 & 3,4 \\
\hline W0 letteren en sociaal-cultureel & 43,1 & $-6,8$ \\
\hline W0 groen & 36,6 & 5,0 \\
\hline WO techniek & 32,7 & 4,4 \\
\hline WO medisch & 2,9 & 0,3 \\
\hline WO economie en recht & 34,0 & 0,3 \\
\hline Totaal (excl. W0, incl. overig) & 18,3 & $-1,8$ \\
\hline
\end{tabular}

Bron: ROA(SIS)

Opmerkingen:

- MBO heeft hier alleen betrekking op de Beroepsopleidende Leerweg (BOL) en niet op de Beroepsbegeleidende Leerweg (BBL, het voormalige leerlingwezen).

- De cijfers voor de opleidingscategorieën op WO-niveau hebben betrekking op 2009. Voor WO is de mutatie van 2009 ten opzichte van 2006 berekend.

Uit tabel 3.3 blijkt dat iets minder dan een vijfde van alle schoolverlaters met een betaalde baan in 2010 werkzaam was onder zijn of haar niveau. Dit betekent dat het door de werkgever vereiste niveau voor de baan lager is dan hun opleidingsniveau. 
In vergelijking met 2006 is de situatie enigszins verbeterd. Het percentage onderbenutting is sindsdien namelijk afgenomen met $\mathrm{I}, 8 \%$-punt. Universitair afgestudeerden werken over het algemeen relatief vaak onder hun niveau, omdat zij als alternatief voor werkloosheid relatief veel mogelijkheden hebben om te solliciteren op vacatures die bedoeld zijn voor afgestudeerden van HBO-niveau. Op deze manier kunnen zij werkervaring opdoen en wellicht doorgroeien naar een hoger functieniveau.

Op VMBO-niveau is het percentage schoolverlaters dat onder het opleidingsniveau werkt flink afgenomen voor VMBO economie en VMBO groen. Van alle opleidingscategorieën is de onderbenutting het hoogst onder Havisten en VWO'ers. Meer dan de helft van hen werkt anderhalf jaar later onder het niveau. Hier is sprake van een zeer grote toename sinds 2006. Het gaat hier, zoals eerder al opgemerkt, om een kleine groep. Onder de $\mathrm{MBO}$-gediplomeerden is de onderbenutting laag voor $\mathrm{MBO}$ sociaal-cultureel en in het bijzonder voor $\mathrm{MBO}$ gezondheidszorg. In vergelijking met 2006 is de onderbenutting het meest afgenomen voor $\mathrm{MBO}$ groen. Op HBO-niveau werken degenen die een lerarenopleiding gevolgd hebben relatief weinig onder hun niveau. Daarentegen werken afgestudeerden van $\mathrm{HBO}$ sociaal-cultureel vaak onder hun niveau. Drie op de tien slagen er in het begin van de loopbaan niet in om een baan op minimaal het eigen niveau te vinden. Meest in het oog springend bij de universitair afgestudeerden is dat medici vrijwel nooit onder hun niveau werken, dit in tegenstelling tot de andere opleidingsrichtingen op dit niveau. Slechts $2,9 \%$ van hen heeft een baan onder het eigen niveau. Van de werkenden met een diploma WO letteren en sociaal-cultureel werkt meer dan $40 \%$ onder het eigen niveau. Wel is dit percentage onderbenutting gedaald ten opzichte van 2006.

\section{Werkzaam buiten vakgebied}

Ook het percentage werkenden dat een baan heeft in een andere richting dan de eerder gevolgde opleidingsrichting geeft een indicatie van de aansluiting tussen onderwijs en arbeidsmarkt. De gedachte die hieraan ten grondslag ligt is dat schoolverlaters doorgaans het liefst een baan hebben die aansluit bij de gevolgde richting. Hoe meer schoolverlaters er werkzaam zijn buiten hun vakgebied, hoe slechter de aansluiting tussen onderwijs en arbeidsmarkt voor de betreffende opleidingscategorie.

Tabel 3.4 laat het percentage werkzame schoolverlaters zien met een baan buiten het eigen vakgebied in 20I0, en de verandering ten opzichte van 2006. Ruim een kwart van de schoolverlaters heeft in 20 Io een baan in een andere richting dan de gevolgde opleiding. Dit aandeel is voor de totale groep sinds 2006 met 0,9\%-punt afgenomen. Vooral op de lagere en middelbare opleidingsniveaus wordt er veel buiten het vakgebied gewerkt. Sinds 2006 hebben er flinke veranderingen plaatsgevonden bij lager opgeleiden.

Bij de middelbare beroepsopleidingen loopt het percentage dat buiten de eigen vakrichting werkt sterk uiteen. Schoolverlaters van $\mathrm{MBO}$ groen of $\mathrm{MBO}$ economie 
accepteren vaak een baan buiten hun richting, voor MBO sociaal-cultureel en $\mathrm{MBO}$ gezondheidszorg geldt dat zij vaak binnen hun vakgebied werkzaam blijven. Verder is het percentage dat buiten het vakgebied werkt het meest gedaald bij MBO sociaalcultureel. MBO'ers met een opleiding techniek en economie zijn juist vaker in een andere richting gaan werken dan in 2006.

\section{Tabel 3.4}

Percentage schoolverlaters werkzaam buiten de eigen vakrichting en mutatie tussen 2006 en 2010, naar opleidingscategorie

\begin{tabular}{|c|c|c|}
\hline & $\begin{array}{c}2010 \\
\%\end{array}$ & Mutatie in \%-punt \\
\hline VMBO tl & 46,5 & $-2,3$ \\
\hline VMBO groen & 27,4 & $-18,9$ \\
\hline VMBO techniek & 25,2 & $-4,6$ \\
\hline VMBO economie & 32,6 & $-15,1$ \\
\hline VMBO verzorging & 50,6 & 18,5 \\
\hline HAVO/VWO & . & . \\
\hline MBO groen & 42,5 & $-2,5$ \\
\hline MBO techniek & 29,1 & 5,7 \\
\hline MBO sociaal-cultureel & 16,8 & $-9,8$ \\
\hline MB0 gezondheidszorg & 11,0 & 2,1 \\
\hline MBO economie & 43,3 & 7,9 \\
\hline HBO onderwijs & 6,9 & $-0,8$ \\
\hline HBO sociaal-cultureel & 26,5 & 1,1 \\
\hline $\mathrm{HBO}$ groen & 23,8 & 1,5 \\
\hline HBO techniek & 13,7 & 1,5 \\
\hline HBO paramedisch & 6,9 & $-1,4$ \\
\hline HBO economie & 33,0 & 2,4 \\
\hline WO letteren en sociaal-cultureel & 31,2 & $-4,0$ \\
\hline WO groen & 27,3 & 8,1 \\
\hline WO techniek & 20,5 & 2,3 \\
\hline WO medisch & 14,4 & 5,7 \\
\hline WO economie en recht & 31,6 & 6,2 \\
\hline Totaal (excl. W0, incl. overig) & 27,2 & $-0,9$ \\
\hline
\end{tabular}

Bron: ROA(SIS)

Opmerkingen:

- MBO heeft hier alleen betrekking op de Beroepsopleidende Leerweg (BOL) en niet op de Beroepsbegeleidende Leerweg (BBL, het voormalige leerlingwezen).

- De cijfers voor de opleidingscategorieën op WO-niveau hebben betrekking op 2009. Voor WO is de mutatie van 2009 ten opzichte van 2006 berekend.

Van de hoger opgeleiden werken degenen met een opleiding HBO economie het vaakst buiten hun richting. Vooral afgestudeerden van de lerarenopleidingen en van techniek en zorg op zowel HBO- als WO-niveau werken relatief weinig buiten de eigen vakrichting. In vergelijking met 2006 werken WO-afgestudeerden vaker buiten de eigen richting, vooral bij de groene opleidingen. 


\section{Deeltijdwerk}

Het percentage deeltijdwerk onder schoolverlaters kan worden gebruikt als indicatie voor een slechte aansluiting onder werkzame schoolverlaters die meer dan 32 uur per week willen werken. Deze indicator geeft echter een minder eenduidige indicatie van de aansluiting tussen onderwijs en arbeidsmarkt dan bijvoorbeeld het werkloosheidspercentage of de beloning van schoolverlaters, omdat een deel van de schoolverlaters graag in deeltijd wil werken. Dit geldt met name voor vrouwen (zie hoofdstuk 4). Toch kan een hoog percentage deeltijders wel degelijk iets zeggen over de arbeidsmarktpositie van schoolverlaters van een bepaalde opleidingscategorie. Zo komt het bij beginnende docenten regelmatig voor dat zij minder lesuren per week hebben dan zij wensen. Dit komt vaker voor naarmate het aantal afgestudeerden toeneemt ten opzichte van het aantal openstaande vacatures in het onderwijs.

In tabel 3.5 wordt voor elke opleidingscategorie gekeken welk percentage van de schoolverlaters een deeltijdbaan heeft in 2010. ${ }^{61}$ Gemiddeld genomen heeft ongeveer de helft van alle schoolverlaters een deeltijdfunctie anderhalf jaar na het afronden van de opleiding. Ten opzichte van 2006 is dit percentage met 7,7\%-punt gestegen. Schoolverlaters van alle VMBO-opleidingscategorieën werken bovengemiddeld vaak in een deeltijdfunctie. Van de schoolverlaters van VMBO theoretische leerweg en $\mathrm{VMBO}$ verzorging heeft zelfs driekwart of meer een deeltijdbaan. Hoewel het percentage deeltijders bij VMBO techniek nog altijd hoger dan gemiddeld is, is dat lager dan in andere richtingen op VMBO-niveau. De technische sector is een door mannen gedomineerde sector, zij werken aanzienlijk minder in deeltijd dan vrouwen. Wel laat het aandeel deeltijders voor VMBO techniek een stijging zien in vergelijking met 2006. Dit geldt overigens ook voor de overige opleidingen op VMBO-niveau, in het bijzonder VMBO groen.

Het aandeel in deeltijd werkende Havisten en VWO'ers is de laatste jaren eveneens sterk toegenomen. Van hen heeft twee derde in 2010 een contract voor I2 tot 32 uur per week. Met uitzondering van $\mathrm{MBO}$ gezondheidszorg, is het aandeel deeltijdwerkers in alle middelbare beroepsopleidingen gestegen. Bij $\mathrm{MBO}$ economie is dit aandeel flink gestegen. Het aandeel deeltijdwerkers bij $\mathrm{MBO}$ gezondheidszorg en vooral $\mathrm{MBO}$ sociaal-cultureel is bovengemiddeld hoog. Bij $\mathrm{MBO}$ techniek is dit aandeel juist vrij laag.

6I. Met een deeltijdbaan wordt hier bedoeld dat een schoolverlater een baan heeft voor tenminste I2 uur en maximaal 32 uur per week. 
Tabel 3.5

Percentage werkzame schoolverlaters met een deeltijdbaan en mutatie tussen 2006 en 2010, naar opleidingscategorie

\begin{tabular}{|c|c|c|}
\hline & $\begin{array}{c}2010 \\
\%\end{array}$ & Mutatie in \%-punt \\
\hline VMBO tl & 75,0 & 7,4 \\
\hline VMBO groen & 71,3 & 18,1 \\
\hline VMBO techniek & 54,5 & 18,4 \\
\hline VMBO economie & 67,9 & 10,1 \\
\hline VMBO verzorging & 76,5 & 9,7 \\
\hline HAVO/VWO & 67,2 & 18,7 \\
\hline MBO groen & 35,2 & 6,9 \\
\hline MBO techniek & 22,7 & 5,0 \\
\hline MBO sociaal-cultureel & 75,8 & 1,5 \\
\hline MB0 gezondheidszorg & 56,9 & $-2,0$ \\
\hline MBO economie & 38,0 & 12,1 \\
\hline $\mathrm{HBO}$ onderwijs & 45,1 & 1,2 \\
\hline HBO sociaal-cultureel & 46,2 & 6,3 \\
\hline HBO groen & 20,6 & 8,5 \\
\hline HBO techniek & 9,4 & 3,9 \\
\hline HBO paramedisch & 59,5 & $-1,5$ \\
\hline HBO economie & 16,9 & 7,1 \\
\hline WO letteren en sociaal-cultureel & 39,3 & $-0,7$ \\
\hline W0 groen & 19,4 & $-0,1$ \\
\hline W0 techniek & 8,1 & 0,8 \\
\hline WO medisch & 11,2 & $-3,0$ \\
\hline WO economie en recht & 7,6 & 0,3 \\
\hline Totaal (excl. W0, incl. overig) & 49,3 & 7,7 \\
\hline
\end{tabular}

Bron: ROA(SIS)

Opmerkingen:

- MBO heeft hier alleen betrekking op de Beroepsopleidende Leerweg (BOL) en niet op de Beroepsbegeleidende Leerweg (BBL, het voormalige leerlingwezen).

- De cijfers voor de opleidingscategorieën op WO-niveau hebben betrekking op 2009. Voor WO is de mutatie van 2009 ten opzichte van 2006 berekend.

Bij $\mathrm{HBO}$ en WO techniek worden vergelijkbare resultaten gevonden als op $\mathrm{MBO}$-niveau en is dit aandeel deeltijdwerkers zelfs nog lager. Dit komt door het grote aandeel mannen die werken in de techniek. Ook van de werkzame schoolverlaters van het $\mathrm{HBO}$ of WO met een diploma richting economie of groen werkt slechts een klein deel in deeltijd. Bij $\mathrm{HBO}$ paramedisch wordt evenals bij $\mathrm{VMBO}$ verzorging en $\mathrm{MBO}$ gezondheidszorg veel in deeltijd gewerkt door de overwegend vrouwelijke arbeidskrachten. Bij WO medisch geldt het tegenovergestelde. Afgestudeerden WO letteren en sociaal-cultureel werken veel vaker in deeltijd dan anderen met een WO-diploma. 


\section{Flexibele arbeid}

Een andere indicator waarmee een verborgen discrepantie van de aansluiting tussen onderwijs en arbeidsmarkt gemeten kan worden is het percentage schoolverlaters dat een flexibele baan heeft. De meeste schoolverlaters prefereren een vaste boven een flexibele baan. Een hoog percentage werknemers met een flexibel contract wijst derhalve op een minder goede arbeidsmarktpositie voor schoolverlaters.

\section{Tabel 3.6}

Percentage schoolverlaters met een flexibele baan en mutatie tussen 2006 en 2010, naar opleidingscategorie

\begin{tabular}{|c|c|c|}
\hline & $\begin{array}{c}2010 \\
\%\end{array}$ & Mutatie in \%-punt \\
\hline VMBO tl & 63,9 & 1,3 \\
\hline VMBO groen & 63,8 & 11,5 \\
\hline VMBO techniek & 47,9 & $-0,2$ \\
\hline VMBO economie & 66,5 & 20,4 \\
\hline VMBO verzorging & 62,8 & 22,3 \\
\hline HAVO/VWO & 49,9 & $-12,4$ \\
\hline MBO groen & 47,0 & 2,2 \\
\hline MBO techniek & 53,1 & 10,0 \\
\hline MBO sociaal-cultureel & 43,8 & $-1,9$ \\
\hline MB0 gezondheidszorg & 48,4 & 17,2 \\
\hline MBO economie & 54,5 & 9,4 \\
\hline HBO onderwijs & 51,5 & 5,3 \\
\hline HBO sociaal-cultureel & 57,1 & 7,7 \\
\hline HBO groen & 55,9 & 5,5 \\
\hline HBO techniek & 43,3 & 7,9 \\
\hline HBO paramedisch & 40,3 & $-1,1$ \\
\hline HBO economie & 50,0 & 7,5 \\
\hline WO letteren en sociaal-cultureel & 58,7 & 0,3 \\
\hline W0 groen & 60,8 & $-5,7$ \\
\hline WO techniek & 43,6 & $-4,3$ \\
\hline WO medisch & 60,8 & $-6,4$ \\
\hline WO economie en recht & 37,8 & 1,4 \\
\hline Totaal (excl. W0, incl. overig) & 52,9 & 6,6 \\
\hline
\end{tabular}

Bron: ROA(SIS)

Opmerkingen:

- MBO heeft hier alleen betrekking op de Beroepsopleidende Leerweg (BOL) en niet op de Beroepsbegeleidende Leerweg (BBL, het voormalige leerlingwezen).

- De cijfers voor de opleidingscategorieën op WO-niveau hebben betrekking op 2008. Voor WO is de mutatie van 2008 ten opzichte van 2006 berekend.

- Het percentage is berekend op basis van de schoolverlaters die een dienstverband hebben. Zelfstandigen worden hier dus buiten beschouwing gelaten. 
Tabel 3.6 geeft per opleidingscategorie weer welk percentage van de werkzame schoolverlaters een flexibele contractvorm heeft in 20I0, en of het percentage flexibel werk toe- of afgenomen is sinds 2006. Het gaat uitsluitend om schoolverlaters met een tijdelijk contract, dus inclusief uitzend- en oproepkrachten, maar exclusief de zelfstandigen, als percentage van het totaal aantal schoolverlaters in dienstverband. Schoolverlaters hebben in vergelijking met de totale groep werknemers in de beroepsbevolking vaak een flexibel contract. ${ }^{62}$ Iets meer dan de helft van de werkzame schoolverlaters heeft in 2010 een flexibel contract, terwijl dat in 2006 nog minder dan de helft was. De ontwikkeling van het aandeel flexwerk loopt echter sterk uiteen voor de verschillende opleidingscategorieën.

Uit tabel 3.6 blijkt dat het aandeel flexwerkers in 2010 vooral hoog is onder VMBOgediplomeerden en bij verschillende $\mathrm{HBO}$ - en WO-richtingen. Bij de VMBO'ers gaat het om alle richtingen met uitzondering van $\mathrm{VMBO}$ techniek. Bij de lager opgeleiden kan dit wijzen op een minder goede arbeidsmarktpositie, maar ook op een tijdelijke positie in het kader van de beroepsbegeleidende leerweg op het $\mathrm{MBO}$, waarin werken en leren gecombineerd wordt. Op WO-niveau gaat het vaak om tijdelijke contracten die bedoeld zijn voor screening door werkgevers of als opleidingsplaats. Te denken valt aan opleidingsplaatsen in ziekenhuizen en promotieplaatsen bij universiteiten. Dergelijke contractvormen wijzen eerder op een goed carrièreperspectief dan op een slechte arbeidsmarktpositie.

\section{Spijt}

Het percentage van de schoolverlaters dat achteraf gezien spijt heeft van de gevolgde opleiding is de laatste indicator voor de aansluiting tussen onderwijs en arbeidsmarkt die hier besproken wordt. Tabel 3.7 laat zien welk deel in 2010 spijt heeft van de eerder gevolgde opleiding en vergelijkt dit met de situatie in 2006. Van de totale groep schoolverlaters heeft bijna één op de vijf spijt van de gekozen opleiding. Dit percentage ligt marginaal hoger dan in 2006. Schoolverlaters van VMBO economie en $\mathrm{VMBO}$ verzorging zijn achteraf het vaakst ontevreden over hun opleiding. Het percentage schoolverlaters met spijt van de gevolgde opleiding is voor laatstgenoemde groep bovendien met een vijfde gestegen ten opzichte van 2006. Maar ook onder lager opgeleiden van de andere richtingen is het percentage met spijt toegenomen. Bij de meeste middelbare beroepsopleidingen, in het bijzonder $\mathrm{MBO}$ groen, en de meeste hogere opleidingen is het percentage schoolverlaters met spijt juist afgenomen. Schoolverlaters met een opleiding economie hebben op alle niveaus relatief vaak spijt, met uitzondering van WO economie en recht. Schoolverlaters van de zorgopleidingen van middelbaar en hoger niveau hebben daarentegen juist weinig spijt van de gevolgde opleiding.

62. D. Bertrand-Cloodt, F. Cörvers, J. van Thor (20I0), 'Betekenis en belang van flexwerk op de arbeidsmarkt', Kwartaalschrift Economie, Vol. 7, pp. 325-357. 
Tabel 3.7

Percentage schoolverlaters dat spijt heeft van de gevolgde opleiding en mutatie tussen 2006 en 2010, naar opleidingscategorie

\begin{tabular}{|c|c|c|}
\hline & $\begin{array}{c}2010 \\
\%\end{array}$ & Mutatie in \%-punt \\
\hline VMBO tl & 15,0 & 8,3 \\
\hline VMBO groen & 14,7 & 1,3 \\
\hline VMBO techniek & 19,9 & 3,5 \\
\hline VMBO economie & 28,8 & 8,8 \\
\hline VMBO verzorging & 31,5 & 19,6 \\
\hline HAVO/VWO & 11,0 & 6,6 \\
\hline MBO groen & 18,6 & $-12,3$ \\
\hline MBO techniek & 17,9 & 1,0 \\
\hline MBO sociaal-cultureel & 18,0 & $-1,9$ \\
\hline MBO gezondheidszorg & 13,1 & $-2,9$ \\
\hline MBO economie & 22,8 & $-3,7$ \\
\hline $\mathrm{HBO}$ onderwijs & 12,2 & 1,5 \\
\hline HBO sociaal-cultureel & 23,0 & $-1,7$ \\
\hline $\mathrm{HBO}$ groen & 24,4 & 0,7 \\
\hline HBO techniek & 13,2 & $-4,5$ \\
\hline HBO paramedisch & 11,6 & $-3,1$ \\
\hline $\mathrm{HBO}$ economie & 26,3 & $-0,6$ \\
\hline W0 letteren en sociaal-cultureel & 15,5 & $-6,5$ \\
\hline WO groen & 23,0 & 5,6 \\
\hline WO techniek & 11,2 & $-3,8$ \\
\hline W0 medisch & 6,5 & $-2,8$ \\
\hline W0 economie en recht & 12,9 & $-2,8$ \\
\hline Totaal (excl. W0, incl. overig) & 18,9 & 1,2 \\
\hline \multicolumn{3}{|c|}{$\begin{array}{l}\text { Bron: ROA(SIS) } \\
\text { Opmerkingen: } \\
\text { - MBO heeft hier alleen betrekking op de Beroepsopleidende Leerweg (BOL) en niet op de } \\
\text { Beroepsbegeleidende Leerweg (BBL, het voormalige leerlingwezen). } \\
\text { - De cijfers voor de opleidingscategorieën op WO-niveau hebben betrekking op 2009. Voor WO is } \\
\text { de mutatie van } 2009 \text { ten opzichte van } 2006 \text { berekend. }\end{array}$} \\
\hline
\end{tabular}

\subsection{Toekomstige arbeidsmarktperspectieven en knelpunten in de personeels- voorziening naar opleiding}

Op basis van de vraag- en aanbodontwikkelingen die in hoofdstuk 2 zijn beschreven en de daaruit voortvloeiende substitutieprocessen op de arbeidsmarkt kan een indicatie worden gegeven van de verwachte arbeidsmarktperspectieven voor schoolverlaters tot 20I6. De verwachte perspectieven worden uitgedrukt in de Indicator Toekomstig Arbeidsmarktperspectief (ITA). Deze indicator geeft voor elke opleidingscategorie de 
verhouding weer tussen het arbeidsaanbod en de arbeidsvraag op de middellange termijn.

Wanneer voor een opleidingscategorie de instroom op de arbeidsmarkt kleiner is dan de vraag naar arbeid, dan is de ITA kleiner dan of gelijk aan I,Oo. Het bijbehorende arbeidsmarktperspectief van schoolverlaters wordt dan als goed of zeer goed aangeduid. Schoolverlaters vinden dan op de middellange termijn relatief eenvoudig een baan die aansluit op de gevolgde opleiding. Is de ITA echter groter dan I,OO, dan hebben schoolverlaters over het algemeen meer moeite met het vinden van een baan die goed aansluit op de gevolgde opleiding. Schoolverlaters met een opleidingsachtergrond waarvoor matige of slechte arbeidsmarktperspectieven voorzien worden, zullen eerder een baan accepteren die onder hun niveau of buiten hun studierichting is. Ook accepteren zij vaker banen met slechtere arbeidsvoorwaarden of waarvoor een langere zoekduur geldt (i.e. een grotere kans op werkloosheid).

De discrepanties tussen vraag en aanbod op de arbeidsmarkt worden weergegeven op het aggregatieniveau van de in hoofdstuk 2 besproken 23 opleidingscategorieën, die verder gedifferentieerd kunnen worden naar IO2 opleidingstypen. Het is mogelijk dat het arbeidsmarktperspectief voor schoolverlaters van een onderliggend opleidingstype afwijkt van het gemiddelde arbeidsmarktperspectief van de opleidingscategorie waartoe het behoort. Hetzelfde geldt voor de knelpunten in de personeelsvoorziening voor werkgevers per opleidingscategorie en opleidingstype. Daarom wordt in deze paragraaf niet alleen ingegaan op de discrepanties tussen vraag en aanbod voor de verschillende opleidingscategorieën, maar ook op de meest opvallende discrepanties in de onderliggende opleidingstypen.

Tabel 3.8 geeft het verwachte arbeidsmarktperspectief weer voor schoolverlaters uit de verschillende opleidingscategorieën. In deze tabel worden zowel de ITA als de bijbehorende typering (zeer goed, goed, redelijk, matig of slecht) gepresenteerd. De twee rechter kolommen bekijken de arbeidsmarktperspectieven vanuit het oogpunt van de werkgever. Deze worden voor de werkgevers weergegeven in de vorm van de Indicator Toekomstige Knelpunten in de Personeelsvoorziening (ITKP). De te verwachten knelpunten bij de werving van personeel kunnen getypeerd worden als respectievelijk zeer groot, groot, enige, vrijwel geen of geen. Navolgend wordt eerst de ITA besproken en vervolgens de ITKP.

Uit tabel 3.8 kunnen enkele algemene conclusies getrokken worden. Voor de komende jaren worden er uiteenlopende arbeidsmarktperspectieven verwacht voor jongeren die in de periode 20II-20I6 de arbeidsmarkt betreden. Voor twaalf van de 23 opleidingscategorieën zijn de verwachte perspectieven voor schoolverlaters goed, voor WO medisch zelfs zeer goed. Dit betekent dat de perspectieven voor de andere opleidingscategorieën redelijk of matig zijn. Op elk opleidingsniveau komen er opleidingen voor met uiteenlopende arbeidsmarktperspectieven. Als er uitsluitend gekeken wordt naar de opleidingsrichting, dan kan er de komende jaren een verslechtering 
van de arbeidsmarktsituatie voor schoolverlaters met een economiediploma verwacht worden. De toekomstperspectieven voor schoolverlaters met een economische opleiding blijken structureel slechter te zijn dan bij andere opleidingsrichtingen, ongeacht het opleidingsniveau. Daar staat tegenover dat op alle opleidingsniveaus de perspectieven voor schoolverlaters met een diploma in de technische richting goed zijn. Dit geldt eveneens voor schoolverlaters met een zorgopleiding.

\section{Tabel 3.8}

Toekomstige arbeidsmarktperspectieven naar opleiding (ITA) voor schoolverlaters, en toekomstige knelpunten in de personeelsvoorziening naar opleiding (ITKP), 2011-2016

\begin{tabular}{|c|c|c|c|c|}
\hline Opleidingscategorie & ITA & $\begin{array}{l}\text { Typering } \\
\text { Arbeidsmarkt- } \\
\text { perspectieven }\end{array}$ & ITKP & $\begin{array}{l}\text { Typering } \\
\text { Knelpunten in de } \\
\text { personeelsvoorziening }\end{array}$ \\
\hline Basisonderwijs & 1,14 & matig & 1,14 & vrijwel geen \\
\hline VMBO tl & 0,88 & goed & 0,88 & groot \\
\hline VMBO groen & 1,06 & matig & 1,08 & vrijwel geen \\
\hline VMBO techniek & 0,91 & goed & 0,92 & groot \\
\hline VMB0 economie & 1,06 & matig & 1,06 & vrijwel geen \\
\hline VMBO verzorging & 0,89 & goed & 0,89 & groot \\
\hline HAVO/VWO & 1,06 & matig & 1,06 & vrijwel geen \\
\hline MBO groen & 0,92 & goed & 0,94 & groot \\
\hline MBO techniek & 0,97 & goed & 0,98 & groot \\
\hline MB0 sociaal-cultureel & 1,05 & redelijk & 1,05 & enige \\
\hline MB0 gezondheidszorg & 0,95 & goed & 0,95 & groot \\
\hline MBO economie & 1,07 & matig & 1,07 & vrijwel geen \\
\hline $\mathrm{HBO}$ onderwijs & 0,89 & goed & 0,90 & groot \\
\hline HBO sociaal-cultureel & 1,07 & matig & 1,07 & vrijwel geen \\
\hline HBO groen & 1,04 & redelijk & 1,04 & enige \\
\hline HBO techniek & 0,96 & goed & 0,96 & groot \\
\hline HBO paramedisch & 0,92 & goed & 0,92 & groot \\
\hline HBO economie & 1,11 & matig & 1,11 & vrijwel geen \\
\hline W0 letteren en sociaal-cultureel & 1,00 & goed & 1,00 & groot \\
\hline WO groen & 1,09 & matig & 1,09 & vrijwel geen \\
\hline WO techniek & 0,97 & goed & 0,97 & groot \\
\hline WO medisch & 0,82 & zeer goed & 0,82 & zeer groot \\
\hline $\begin{array}{l}\text { W0 economie en recht } \\
\text { Bron: ROA(AIS) }\end{array}$ & 1,11 & matig & 1,11 & vrijwel geen \\
\hline
\end{tabular}

Verder blijkt uit de tabel dat het toekomstige arbeidsmarktperspectief van schoolverlaters met uitsluitend Basisonderwijs (vaak drop-outs van het VMBO) voor de middellange termijn matig is. Dit is met name te wijten aan een zeer hoge arbeidsmarktinstroom van gemiddeld jaarlijks 6,3\% van de werkgelegenheid in 20I0. Het toekomstige arbeidsmarktperspectief voor VMBO tl is goed. Dit wordt veroorzaakt door een erg hoge vervangingsvraag in combinatie met een relatief laag aanbod van arbeidskrachten uit deze opleidingscategorie. De arbeidsmarktperspectieven voor VMBO groen zijn matig. Dit komt door een krimpende werkgelegenheid, terwijl er 
bovendien relatief veel instromers op de arbeidsmarkt zullen zijn. Voor schoolverlaters van $\mathrm{VMBO}$ techniek zijn de arbeidsmarktperspectieven veel beter, hetgeen binnen deze richting met name geldt voor VMBO bouwtechniek. Dit komt vooral door de beperkte belangstelling voor opleidingen binnen VMBO techniek. Alleen de perspectieven voor schoolverlaters van VMBO grafische techniek zijn matig.

Voor VMBO economie is het verwachte arbeidsmarktperspectief tot 2016 matig. Voor deze opleidingscategorie wordt een relatief hoge instroom verwacht, terwijl de vervangingsvraag niet veel hoger dan gemiddeld is. Binnen deze opleidingscategorie zijn de arbeidsmarktvooruitzichten voor VMBO consumptief en levensmiddelentechniek slecht. Het arbeidsmarktperspectief voor VMBO verzorging is de komende jaren goed. Dit komt door een combinatie van een stijgende werkgelegenheid, een relatief hoge vervangingsvraag en een lage instroom. De goede arbeidsmarktperspectieven voor schoolverlaters van een aantal richtingen van het $\mathrm{VMBO}$ dienen echter gerelativeerd te worden, omdat veel van deze schoolverlaters in hetzij laaggeschoolde banen met weinig toekomstperspectief terecht komen, hetzij in leer-werk banen. Dit laatste gebeurt dan vaak in combinatie met een opleiding in de beroepsbegeleidende leerweg van het MBO. Het is voor veel VMBO-schoolverlaters nog niet zo moeilijk om werk te vinden kort na het verlaten van de opleiding, maar wel om werk te houden. Dit geldt vooral als zij er niet in slagen om binnen enkele jaren een startkwalificatie voor de arbeidsmarkt te halen (i.e. minimaal niveau 2 van het $\mathrm{MBO}$, zie ook hoofdstuk I).

Schoolverlaters met een HAVO/VWO-diploma hebben matige vooruitzichten om aan de slag te komen. Hoewel er in de komende jaren een hoge vervangingsvraag wordt verwacht voor HAVO/VWO'ers, staat hier een nog grotere toename van het aanbod tegenover. Bij de vervangingsvraag gaat het voor een belangrijk deel om werkenden die alsnog een opleiding in het hoger onderwijs afronden, en bij het arbeidsaanbod om werkende lager opgeleiden die alsnog een HAVO-diploma halen.

De arbeidsmarktperspectieven voor $\mathrm{MBO}$ groen en $\mathrm{MBO}$ techniek zijn goed. $\mathrm{Bij}$ deze opleidingscategorieën is sprake van een vrij lage verwachte instroom van arbeidskrachten en een relatief hoge vervangingsvraag, terwijl de werkgelegenheid licht krimpt. Er zijn echter wel onderliggende opleidingstypen waarvoor een ongunstig toekomstig arbeidsmarktperspectief verwacht wordt, namelijk: $\mathrm{MBO}$ installatietechniek, $\mathrm{MBO}$ vliegtuigtechniek, $\mathrm{MBO}$ operationele techniek, $\mathrm{MBO}$ grafische techniek, $\mathrm{MBO}$ procestechniek en $\mathrm{MBO}$ vervoer. Voor $\mathrm{MBO}$ sociaal-cultureel houdt de vraag min of meer gelijke tred met het fors toenemende aanbod van schoolverlaters op de arbeidsmarkt, waardoor de arbeidsmarktperspectieven redelijk zijn. Het enige onderliggende opleidingstype met slechte arbeidsmarktperspectieven is hier MBO sociaalpedagogisch en welzijn.

De arbeidsmarktvooruitzichten voor afgestudeerden van $\mathrm{MBO}$ gezondheidszorg zijn goed. De instroom van nieuwe arbeidskrachten is iets hoger dan gemiddeld, terwijl door de combinatie van een relatief hoge uitbreidingsvraag en een lager dan gemid- 
delde vervangingsvraag het aantal baanopeningen meer dan voldoende is om het nieuwe aanbod te absorberen. Binnen $\mathrm{MBO}$ gezondheidszorg zijn de arbeidsmarktperspectieven van $\mathrm{MBO}$ gezondheidstechniek en $\mathrm{MBO}$ beweging en therapie echter ongunstig. Van alle $\mathrm{MBO}$-gediplomeerden zijn de arbeidsmarktperspectieven van gediplomeerden $\mathrm{MBO}$ economie het minst gunstig. De verwachte arbeidsmarktinstroom is bovengemiddeld, terwijl de werkgelegenheid en de vervangingsvraag iets lager dan gemiddeld zijn. De economische opleidingen met de slechtste vooruitzichten zijn $\mathrm{MBO}$ toerisme en recreatie en MBO ICT.

Voor HBO onderwijs zijn de toekomstige arbeidsmarktperspectieven van afgestudeerden van lerarenopleidingen goed. Dit komt met name door de relatief grote vervangingsvraag, maar ook door de vrije lage deelname aan de lerarenopleidingen waardoor er weinig afgestudeerden van $\mathrm{HBO}$ onderwijs instromen op de arbeidsmarkt. Vooral voor afgestudeerden van de HBO lerarenopleidingen natuur en techniek en HBO lerarenopleidingen medisch en verzorging zijn de perspectieven goed. Het arbeidsmarktperspectief voor HBO lerarenopleidingen lichamelijke opvoeding is echter ongunstig.

Voor $\mathrm{HBO}$ sociaal-cultureel en $\mathrm{HBO}$ economie zijn de arbeidsmarktperspectieven matig. Bij $\mathrm{HBO}$ sociaal-cultureel ligt de verwachte arbeidsmarktinstroom iets boven het gemiddelde, terwijl de vervangingsvraag lager is dan gemiddeld. Binnen HBO sociaal-cultureel hebben afgestudeerden van $\mathrm{HBO}$ tolk en vertaler en $\mathrm{HBO}$ uitvoerende en beeldende kunsten gunstige arbeidsmarktperspectieven, terwijl de arbeidsmarktperspectieven van $\mathrm{HBO}$ communicatie en journalistiek en $\mathrm{HBO}$ horeca het slechtst zijn. Bij HBO economie is de verwachte arbeidsmarktinstroom gemiddeld, terwijl de werkgelegenheid en de vervangingsvraag lager dan gemiddeld zijn. Binnen $\mathrm{HBO}$ economie zijn de arbeidsmarktperspectieven van $\mathrm{HBO}$ accountancy en bedrijfseconomie en $\mathrm{HBO}$ openbare orde en veiligheid goed, terwijl de arbeidsmarktperspectieven van $\mathrm{HBO}$ commerciële economie, $\mathrm{HBO}$ toerisme en recreatie en $\mathrm{HBO}$ secretariaat het meest ongunstig zijn.

Voor HBO groen zijn de arbeidsmarktperspectieven tot 2016 redelijk. Voor deze opleidingscategorie wordt een relatief lage instroom op de arbeidsmarkt verwacht, maar is ook het aantal baanopeningen niet groot. De arbeidsmarktperspectieven voor $\mathrm{HBO}$ techniek en $\mathrm{HBO}$ paramedisch zijn goed. Bij $\mathrm{HBO}$ techniek komt dat vooral door een wat hogere vervangingsvraag en een lager dan gemiddelde arbeidsmarktinstroom, bij $\mathrm{HBO}$ paramedisch door een bovengemiddeld grote uitbreidingsvraag. Binnen $\mathrm{HBO}$ techniek zijn de perspectieven voor $\mathrm{HBO}$ laboratorium en $\mathrm{HBO}$ chemische technologie zelfs zeer goed, terwijl afgestudeerden van HBO informatica het de komende periode het moeilijkst hebben om een goede baan te vinden.

Ook de arbeidsmarktperspectieven op WO-niveau verschillen nogal tussen de diverse richtingen. Voor WO letteren en sociaal-cultureel en WO techniek zijn de verwachte arbeidsmarktperspectieven goed. Binnen WO letteren en sociaal-cultureel is het 
arbeidsmarktperspectief voor WO theologie zelfs zeer goed door de hoge vervangingsvraag. Binnen WO techniek zijn de arbeidsmarktperspectieven voor WO bouwkunde en WO werktuigbouwkunde zeer goed, terwijl afgestudeerden van WO informatica en bestuurlijke informatiekunde het de komende periode het moeilijkst hebben om in een goed aansluitende baan aan de slag te raken.

De vooruitzichten voor WO groen en WO economie en recht zijn matig. Hoewel de verwachte werkgelegenheidstoename voor WO groen boven het gemiddelde ligt en de arbeidsmarktinstroom iets onder het gemiddelde, zorgt een zeer lage vervangingsvraag toch voor matige vooruitzichten. Ook voor WO economie en recht zijn de arbeidsmarktperspectieven matig door een relatief lage vervangingsvraag en een arbeidsmarktinstroom die wat hoger dan gemiddeld ligt. Binnen WO economie en recht zijn de arbeidsmarktperspectieven voor WO econom(etr)ie het meest gunstig, terwijl deze voor WO bedrijfskunde het meest ongunstig zijn.

De arbeidsmarktperspectieven voor WO medisch zijn veel beter dan voor WO groen en WO economie en recht, ondanks een vrij hoge verwachte instroom op de arbeidsmarkt. Door de relatief grote uitbreidingsvraag en vervangingsvraag wordt er een zeer goed arbeidsmarktperspectief verwacht. Alleen voor afgestudeerden van WO farmacie en medische biologie is het perspectief goed in plaats van zeer goed.

Naast de ITA voor schoolverlaters en werkzoekenden wordt in tabel 3.8 tevens de Indicator Toekomstige Knelpunten in de Personeelsvoorziening (ITKP) voor werkgevers weergegeven. De ITKP geeft een indruk van de toekomstige wervingsproblemen die werkgevers kunnen verwachten voor de verschillende opleidingscategorieën en is vaak tegengesteld aan de ITA. In 'Doel en opzet van de arbeidsmarktprognoses' aan het begin van dit rapport werd reeds aangegeven dat de ITKP alleen afwijkt van de ITA voor opleidingscategorieën met een krimpende werkgelegenheid. Indien werkgevers knelpunten in de personeelsvoorziening verwachten bij opleidingscategorieën die gekenmerkt worden door een krimpende werkgelegenheid, zullen zij de mogelijkheid aangrijpen om de uitstroom van het zittende personeel af te remmen. Op deze manier wordt de vereiste instroom van nieuwkomers die nodig is om aan de verwachte vraag naar personeel te kunnen voldoen lager. Als de ITKP kleiner dan of gelijk is aan I,OO worden de verwachte knelpunten in de personeelsvoorziening als groot getypeerd. $\mathrm{Bij}$ een ITKP die groter is dan I,oo kunnen werkgevers enige tot (vrijwel) geen knelpunten in de personeelsvoorziening verwachten, afhankelijk van de grootte van de ITKP.

Uit de twee rechter kolommen van tabel 3.8 blijkt dat werkgevers de komende jaren voor de helft van de opleidingscategorieën grote inspanningen zullen moeten verrichten om hun vacatures in te vullen waarvoor een dergelijke opleidingsachtergrond vereist is. Het zal voor werkgevers over het algemeen moeilijk zijn geschikt personeel te vinden onder schoolverlaters van VMBO tl, VMBO techniek en VMBO verzorging. Binnen $\mathrm{VMBO}$ techniek worden grote knelpunten verwacht voor de 
opleidingstypen VMBO installatietechniek, VMBO metaaltechniek, VMBO voertuigentechniek, VMBO elektrotechniek en VMBO transport en logistiek. Voor VMBO bouwtechniek worden zelfs zeer grote knelpunten verwacht.

Ook op de hogere opleidingsniveaus kunnen werkgevers een aantal grote knelpunten verwachten. Dit is met name het geval bij opleidingen gericht op techniek, zorg en onderwijs. Binnen $\mathrm{MBO}$ groen worden grote knelpunten verwacht voor het opleidingstype $\mathrm{MBO}$ voeding, natuur en milieu. Voor $\mathrm{MBO}$ techniek worden grote knelpunten verwacht voor verschillende opleidingen: $\mathrm{MBO}$ laboratorium, MBO bouw, $\mathrm{MBO}$ grond-, weg- en waterbouw, $\mathrm{MBO}$ werktuigbouw en mechanische techniek, $\mathrm{MBO}$ fijnmechanische techniek, $\mathrm{MBO}$ elektrotechniek, $\mathrm{MBO}$ brood en banket en MBO levensmiddelentechniek/vleesverwerking. Voor MBO gezondheidszorg is er op de middellange termijn met name schaarste onder schoolverlaters met een opleiding MBO dokters-, tandarts- en dierenartsassistent, $\mathrm{MBO}$ apothekersassistent en $\mathrm{MBO}$ verpleging.

Op HBO-niveau zijn de knelpunten in de personeelsvoorziening het grootst voor $\mathrm{HBO}$ onderwijs, $\mathrm{HBO}$ techniek en $\mathrm{HBO}$ paramedisch. Voor HBO onderwijs zijn er twee opleidingstypen waar zelfs zeer grote problemen verwacht kunnen worden bij het invullen van vacatures, namelijk HBO lerarenopleidingen natuur en techniek en HBO lerarenopleidingen medisch en verzorging. Daarnaast zijn er nog enkele opleidingstypen waarvoor werkgevers grote knelpunten tegemoet kunnen zien, te weten $\mathrm{HBO}$ lerarenopleidingen basisonderwijs, HBO lerarenopleidingen talen, HBO lerarenopleidingen economie en maatschappij en $\mathrm{HBO}$ lerarenopleidingen expressie. Voor HBO techniek geldt dat er op de middellange termijn zeer grote knelpunten voorzien worden voor $\mathrm{HBO}$ laboratorium en $\mathrm{HBO}$ chemische technologie. Grote knelpunten worden verwacht voor $\mathrm{HBO}$ civiele techniek, $\mathrm{HBO}$ werktuigbouwkunde, $\mathrm{HBO}$ elektrotechniek en $\mathrm{HBO}$ vervoer en logistiek. Voor HBO paramedisch geldt dat er grote knelpunten voorzien worden voor $\mathrm{HBO}$ verpleegkunde, $\mathrm{HBO}$ radiologie en HBO (fysio)therapie.

De grootste personeelsschaarste aan universitair opgeleiden wordt verwacht in de technische en medische richting. Voor WO techniek worden de grootste knelpunten in de personeelsvoorziening verwacht voor WO bouwkunde en WO werktuigbouwkunde. Grote knelpunten worden eveneens verwacht voor WO wiskunde en natuurwetenschappen en WO civiele techniek. Bij WO letteren en sociaal-cultureel worden de grootste knelpunten verwacht voor WO theologie.

\subsection{Beroepen, beloning en loonmobiliteit}

Vraag- en aanbodverhoudingen op de arbeidsmarkt bepalen in grote mate het loon van werknemers in de verschillende beroepen. De ontwikkeling van deze verhouding in de tijd bepaalt hoe de lonen zich ontwikkelen. Andere factoren die de beloning, en 
dus ook de verschillen in beloning tussen beroepen, bepalen zijn de samenstelling naar opleidingsniveau, leeftijd en geslacht, maar ook de relatieve (on)aantrekkelijkheid van het werk en de daarmee gepaard gaande compenserende loonverschillen. Informatie over de beloning naar beroep en de loonontwikkeling kan van groot belang zijn bij de keuze voor een beroep. Ook de loonverschillen binnen een beroep kunnen daarbij een rol spelen (zie ook hoofdstuk 5).

Om de beloning in beroepen in beeld te brengen is er een koppeling gemaakt tussen het Sociaal Statistisch Bestand (SSB) voor gegevens over de beloning van werknemers met de Enquête Beroepsbevolking (EBB) voor informatie over het beroep dat door deze werknemers wordt uitgeoefend. De koppeling is gemaakt voor de jaren $200 \mathrm{I}$ en 2008 waardoor het mogelijk is om een beeld te schetsen van de ontwikkeling van het uurloon over deze periode.

\section{Figuur 3.1}

Bruto uurloon van werknemers per beroepsklasse in 2008 en de reële loonontwikkeling in de periode 2001-2008

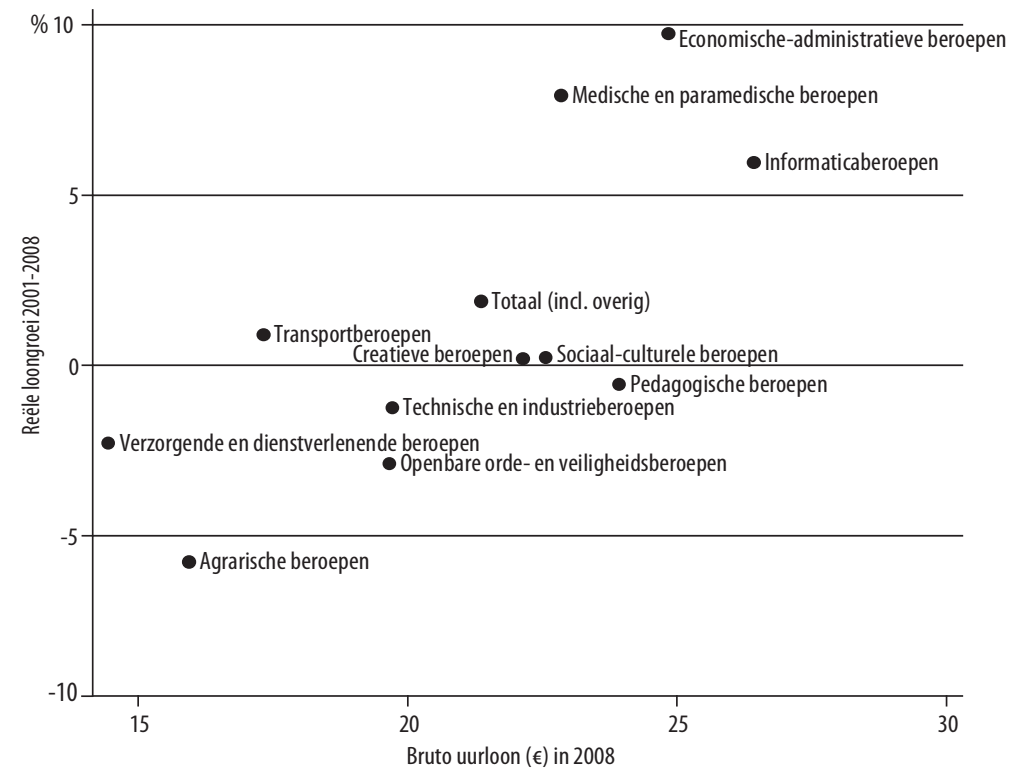

Bron: $\mathrm{CBS}(\mathrm{SSB}, \mathrm{EBB})$, bewerking ROA

Figuur 3.I laat het bruto uurloon van werknemers (exclusief zelfstandigen) per beroepsklasse zien voor het jaar 2008, alsmede de loonontwikkeling in de periode $200 \mathrm{I}-2008 .{ }^{63}$ Het gemiddelde bruto uurloon bedroeg in 2008 ongeveer $€ 2 \mathrm{I}, 40$. De nominale loongroei in de periode bedroeg $16,5 \%$. Na correctie voor inflatie blijkt de

63. De loonontwikkeling is berekend per beroep in de cross-sectie gegevens. 
reële loongroei slechts I,9\% te zijn. Figuur 3.I laat zien dat het bruto uurloon net als de reële loongroei sterk uiteenloopt tussen de beroepsklassen, maar dat er een positief verband is tussen loonhoogte en loongroei. Zo verdienen werknemers in de medische en paramedische beroepen, economische-administratieve beroepen en informaticaberoepen een relatief hoog bruto uurloon, respectievelijk $€ 22,90, € 24,80$ en $€ 26,40$. Deze beroepen vertonen eveneens een relatief sterke loongroei, namelijk respectievelijk $7,9 \%, 9,7 \%$ en $5,9 \%$. Werknemers in de pedagogische beroepen, sociaal-culturele beroepen en creatieve beroepen verdienen ook meer dan gemiddeld, maar voor hen geldt dat hun loon in reële termen nagenoeg onveranderd is gebleven tussen $200 \mathrm{I}$ en 2008 . Een sterke loondaling van $-5,8 \%$ tussen 200 en 2008 is waargenomen voor werknemers in de agrarische beroepen. Het gaat hierbij om beroepen met een relatief laag bruto uurloon van $€ 15,90$. Werknemers in de verzorgende en dienstverlenende beroepen verdienen met $€ \mathrm{I} 4,50$ het minst. De reële loonverandering in deze beroepen was ook negatief: een daling van $2,3 \%$ tussen 200 i en 2008 .

Tabel 3.9

Loonongelijkheid binnen beroepsklassen (p9o/p10), 2001 en 2008

\begin{tabular}{lccc}
\hline Beroepsklasse & 2001 & 2008 & $\begin{array}{c}\text { Verschil in } \\
\%\end{array}$ \\
\hline Pedagogische beroepen & & 1,96 & 0 \\
\hline Creatieve beroepen & 1,96 & 2,84 & 19 \\
\hline Agrarische beroepen & 2,39 & 2,51 & 1 \\
\hline Technische en industrieberoepen & 2,47 & 2,61 & 8 \\
\hline Transportberoepen & 2,42 & 2,36 & 14 \\
\hline Medische en paramedische beroepen & 2,08 & 2,59 & 19 \\
\hline Economisch-administratieve beroepen & 2,19 & 3,21 & 16 \\
\hline Informaticaberoepen & 2,76 & 2,52 & 8 \\
\hline Sociaal-culturele beroepen & 2,34 & 2,21 & -1 \\
\hline Verzorgende en dienstverlenende beroepen & 2,22 & 2,22 & 6 \\
\hline Openbare orde- en veiligheidsberoepen & 2,10 & 2,14 & 12 \\
\hline Totaal (incl. overig) & 2,19 & 2,97 & 12
\end{tabular}

Bron: $\mathrm{CBS}(\mathrm{SSB}, \mathrm{EBB})$, bewerking door ROA

Opmerking:

Voor de berekening van $\mathrm{p} 90 / \mathrm{p} 10$ is het bruto uurloon van de werknemers van het 90e percentiel gedeeld door het bruto uurloon van de werknemers van het 10e percentiel.

De reële loongroei, weergegeven in figuur 3.I, wordt beïnvloed doordat de leeftijdssamenstelling binnen het beroep in de loop van de tijd is veranderd door instroom van nieuwe medewerkers en uitstroom van oudere medewerkers. Het gekoppelde SSB-EBB bestand maakt het echter mogelijk om individuen in de EBB 200 terug te vinden in de SSB 2008. Op deze wijze kan men vaststellen hoe de loonontwikkeling van werknemers in een bepaald beroep in $200 \mathrm{I}$ is geweest tussen $200 \mathrm{I}$ en 2008 . Zo kan de loonontwikkeling van individuen geanalyseerd worden. Er blijkt dat ongeveer een derde van de werknemers tussen 200 I en 2008 twee of meer decielen is opgeschoven (naar boven of naar beneden) in de loonverdeling. Al met al zijn personen met een baan in $200 \mathrm{I}$ en 2008 in die periode 7,I\% (in reële termen) meer gaan verdienen. Het 
verschil tussen deze loongroei op individueel niveau en de gemiddelde ontwikkeling van het loon van I,9\% (zoals besproken in figuur 3.I) kan men interpreteren als de opbrengsten van opgebouwde ervaring en eventueel gevolgde scholing in de betreffende periode. De grootste stijging wordt gevonden voor werknemers die in $200 \mathrm{I}$ werkzaam waren in de medische en paramedische beroepen $(\mathrm{I} 3, \mathrm{O} \%)$, economischeadministratieve beroepen (I6,4\%) en informaticaberoepen (I4,7\%). De kleinste stijging in die periode wordt gemeten voor werknemers in de agrarische beroepen $(3,2 \%)$, technische en industrieberoepen $(2,5 \%)$ en transportberoepen $(4,0 \%)$.

Figuur 3.I geeft het gemiddelde loon in de verschillende beroepsklassen weer. Sommige werknemers verdienen echter meer dan gemiddeld, anderen juist minder. Tabel 3.9 geeft een overzicht van de verhouding tussen de hoogste lonen binnen een bepaalde beroepsklasse ten opzichte van de laagste lonen in die beroepsklasse. Er wordt gebruik gemaakt van de percentielratio, waarbij het bruto uurloon van het $90^{\mathrm{e}}$ percentiel gedeeld wordt door het bruto uurloon van het $\mathrm{IO}^{\mathrm{e}}$ percentiel. ${ }^{64}$ Een groot loonverschil tussen de meest- en minstverdienenden kan duiden op een grote diversiteit in de beroepsniveaus binnen beroepsklassen, en deze kan samenhangen met verschillen in opleiding, leeftijd en ervaring. Tabel 3.9 laat zien dat de werknemers met de hoogste lonen in 2008 bijna drie keer zo veel verdienen als de werknemers met de laagste lonen. De ongelijkheid in bruto uurlonen is bovendien met ongeveer I $2 \%$ toegenomen tussen $200 \mathrm{I}$ en $2008 .{ }^{65}$ De ongelijkheid in bruto uurloon is anno 2008 vooral groot in de economische-administratieve beroepen en creatieve beroepen. De lonen zijn het meest gelijk verdeeld onder werknemers in de pedagogische beroepen en openbare- en veiligheidsberoepen. Maar zelfs daar verdienen de meest verdienenden ongeveer twee keer zoveel als de minstverdienenden. De loonongelijkheid is tussen 200 I en 2008 het meest gestegen in de creatieve beroepen, medische en paramedische beroepen, economische-administratieve beroepen en transportberoepen.

\subsection{Toekomstige knelpunten in de personeelsvoorziening naar beroep}

Paragraaf 3.3 gaf reeds een overzicht van de knelpunten in de personeelsvoorziening voor werkgevers gedifferentieerd naar opleidingscategorie. Deze aansluitingsproblematiek zal ook zijn weerslag hebben op de arbeidsmarkt voor de verschillende beroepsgroepen. Wanneer voor een bepaald beroep specifieke kennis en vaardigheden vereist zijn die vooral aanwezig zijn bij arbeidskrachten uit een opleidingscategorie waarvoor grote tekorten verwacht worden, zullen werkgevers moeite hebben om voldoende geschikt personeel te vinden dat beschikt over de vereiste kwalificaties.

64. De bijlage bij hoofdstuk 5 geeft een meer gedetailleerd overzicht van de beloningsverschillen binnen beroepen.

65. Deze toename in loonongelijkheid wordt bevestigd als de ongelijkheidsmaatstaf van Theil wordt gebruikt. Uit een decompositie van de ongelijkheid binnen en tussen beroepsklassen blijkt dat ongeveer $14 \%$ van de loonongelijkheid het gevolg is van de ongelijkheid tussen beroepen. Deze verhouding is tussen $200 \mathrm{I}$ en 2008 nauwelijks veranderd. 
Indien het over zeer beroepsspecifieke expertise gaat, zullen de knelpunten moeilijk opgelost kunnen worden omdat er weinig alternatieven voorhanden zijn. Werkgevers die op zoek zijn naar personeel met generieke competenties, kunnen gemakkelijker kiezen voor arbeidskrachten met een andere opleidingsachtergrond.

Door middel van de Indicator Toekomstige Knelpunten in de Personeelsvoorziening naar Beroep (ITKB) kan een beter inzicht verschaft worden in de wijze waarop de aansluitingsproblemen tussen onderwijs en arbeidsmarkt van invloed zijn op de wervingsproblematiek in de verschillende beroepsgroepen. De ITKB geeft aan in welke mate het voor werkgevers mogelijk is om binnen beroepsgroepen de gewenste personeelssamenstelling naar opleidingsachtergrond te realiseren, rekening houdende met de vraag-aanbod-verhoudingen voor de verschillende opleidingstypen. De ITKB heeft een waarde tussen o en I en naarmate de indicator lager is, zijn de knelpunten groter voor de opleidingscategorieën die voor de betreffende beroepsgroep relevant zijn. Wanneer de ITKB daarentegen dichter bij I ligt, zullen werkgevers minder moeite hebben de gewenste personeelssamenstelling te realiseren.

Een goed inzicht in de knelpunten naar beroep kan voor verschillende gebruikers en gebruiksdoelen van belang zijn. Allereerst formuleren werkgevers de behoefte aan nieuw personeel vaak primair in termen van functiecategorieën of beroepen. $\mathrm{Zij}$ zijn immers op zoek naar iemand die bepaalde taken - gebundeld in een bepaalde functiecategorie - binnen de organisatie kan vervullen. Voor werkgevers kan inzicht in de knelpunten naar beroepsgroep dus van belang zijn voor hun wervings- en personeelsbeleid. Daarnaast kunnen (langdurig) werklozen of werkenden die op zoek zijn naar een andere werkkring gebruik maken van de informatie over de knelpunten in de personeelsvoorziening naar beroep in hun oriëntatie naar een nieuwe of andere werkkring. Nauw samenhangend met het tweede gebruiksdoel zijn de bij- en omscholingsprogramma's, omdat deze doorgaans gericht zijn op een bepaald beroep. Inzicht in de knelpunten naar beroep kan als leidraad dienen bij het vormgeven en inrichten van dergelijke scholingsprogramma's.

Tabel 3.Io geeft de verwachte knelpunten in de personeelsvoorziening voor werkgevers weer naar beroep voor de periode tot 20I6. Voor elke beroepsklasse wordt de ITKB en de bijbehorende typering weergegeven. De laatste twee kolommen van de tabel laten het percentage van de werkenden zien waarvoor werkgevers (zeer) grote of (vrijwel) geen knelpunten kunnen verwachten. Dit is van belang als er vacatures ontstaan vanwege vertrek (om welke reden dan ook) van personeel in de betreffende functies. De percentages zijn gebaseerd op de typeringen van de knelpunten van de beroepsgroepen die samen een beroepsklasse vormen (zie Bijlage B). Uit de tabel valt af te lezen dat werkgevers tot 2016 geconfronteerd worden met knelpunten in de personeelsvoorziening voor de helft van alle werkenden. Omdat de arbeidsmarkt voor de beroepsgroepen van deze werkenden krap is, zullen er eerder vacatures ontstaan vanwege vrijwillig vertrek van personeel in de betreffende functies. Voor $38 \%$ van de 
werkenden is er geen schaarste op de arbeidsmarkt, en voor de resterende $12 \%$ is de arbeidsmarkt min of meer in evenwicht.

\section{Tabel 3.10}

Toekomstige Knelpunten in de personeelsvoorziening naar Beroep (ITKB) voor werkgevers, en percentage werkenden naar ITKB-typering, 2011-2016

\begin{tabular}{lllcc|} 
Beroepsklasse & ITKB & ITKB-typering & $\begin{array}{c}\text { (Vrijwel) geen } \\
\text { knelpunten } \\
\%\end{array}$ & $\begin{array}{c}\text { (Zeer) grote } \\
\text { knelpunten } \\
\%\end{array}$ \\
\hline Pedagogische beroepen & & groot & 15 & 82 \\
\hline Creatieve beroepen & 0,751 & vrijwel geen & 46 & 4 \\
\hline Agrarische beroepen & 0,817 & groot & 1 & 54 \\
\hline Technische en industrieberoepen & 0,776 & groot & 8 & 75 \\
\hline Transportberoepen & 0,758 & enige & 4 & 4 \\
\hline Medische en paramedische beroepen & 0,789 & zeer groot & 0 & 100 \\
\hline Economisch-administratieve beroepen & 0,668 & vrijwel geen & 87 & 10 \\
\hline Informaticaberoepen & 0,824 & vrijwel geen & 100 & 0 \\
\hline Sociaal-culturele beroepen & 0,848 & vrijwel geen & 78 & 0 \\
\hline Verzorgende en dienstverlenende beroepen & 0,724 & groot & 10 & 90 \\
\hline Openbare orde- en veiligheidsberoepen & 0,799 & enige & 42 & 58 \\
\hline Totaal (incl. overig) & & & 38 & 50
\end{tabular}

Bron: $\operatorname{ROA}(\mathrm{AIS})$

Uit tabel 3.Io kan verder geconcludeerd worden dat werkgevers de komende jaren rekening moeten houden met grote knelpunten in de personeelsvoorziening voor de pedagogische beroepen. Ruim acht van de tien werkenden in de pedagogische beroepen werkt in een beroepsgroep waarvoor (zeer) grote knelpunten worden voorzien. De knelpunten zijn groot voor leraren basisonderwijs, docenten exacte, medische en verzorgende vakken (2e graads), docenten exacte, medische en verzorgende vakken (Ie graads en WO), docenten landbouw en techniek (2e graads), docenten talen en expressie, docenten letteren (Ie graads en WO), docenten ze graads zonder specialisatie, zweminstructeurs en onderwijskundigen en pedagogen.

In tegenstelling tot de pedagogische beroepen worden voor de creatieve beroepen nauwelijks knelpunten verwacht in de personeelsvoorziening. Slechts $4 \%$ van de arbeidskrachten met een creatief beroep werkt in een beroepsgroep waarin problemen verwacht worden aangaande de personeelswerving. Het betreft hier de vacatures die zullen ontstaan voor geestelijken.

Voor de agrarische beroepen en technische en industrieberoepen kan de komende jaren grote schaarste aan personeel worden verwacht. Ruim de helft van de werkenden in de agrarische beroepen werkt in een beroepsgroep waarvoor grote knelpunten voorzien worden. In de agrarische beroepsklasse zullen op de middellange termijn grote problemen ontstaan om voldoende agrarische vakkrachten, milieuhygiënisten en agrarisch vertegenwoordigers en agrarische bedrijfshoofden te vinden. Ook werk- 
gevers in de technische en industrieberoepen zullen op de middellange termijn met grote schaarste aan personeel rekening moeten houden. Het zal vooral moeilijk zijn om voldoende technisch analisten, werktuigbouwkundigen, weg- en waterbouwkundigen en grafische vakkrachten te vinden. Daarnaast worden er grote knelpunten verwacht voor verschillende beroepsgroepen, te weten laboratoriumassistenten, laboranten, natuurwetenschappers, conciërges, bouwvakkers, aannemers en installateurs, architecten en bouwkundig projectleiders, weg- en waterbouwkundig ontwerpers en projectleiders, metaalarbeiders, bankwerkers en lassers, bedrijfshoofden metaalbewerking, monteurs, werktuigbouwkundig ontwerpers en hoofden technische dienst, elektronicamonteurs, monteurs en controleurs elektrotechnische producten, elektromonteurs, elektrotechnisch ontwerpers en bedrijfshoofden en procestechnologen. Voor de transportberoepen is er over het algemeen voldoende aanbod op de arbeidsmarkt en worden er geen grote knelpunten in de personeelsvoorziening verwacht, behalve voor de vliegers, scheepskapiteins en leidinggevenden transport.

Voor de medische en paramedische beroepen worden in de periode tot 2016 de grootste tekorten voorspeld. Het grootst zijn de wervingsproblemen voor verpleeghulpen en leerling-verpleegkundigen, verplegenden en doktersassistenten, therapeuten en verpleegkundigen, artsen en medisch analisten. Ook bij vacatures voor apothekersassistenten en medisch laboranten, apothekers en afdelingshoofden van zorginstellingen worden grote knelpunten in de personeelsvoorziening voor werkgevers verwacht.

Werkgevers in de economisch-administratieve beroepen, informaticaberoepen en sociaal-culturele beroepen zullen op de middellange termijn weinig problemen in de personeelsvoorziening kennen. Binnen de economisch-administratieve beroepsklasse zijn er wel enkele beroepsgroepen waarvoor werkgevers (zeer) grote moeilijkheden kunnen ondervinden bij het invullen van vacatures. Dit geldt met name voor economen, ondersteunende administratieve hulpkrachten, productieplanners, organisatiedeskundigen, technisch-commercieel employés en technisch-bedrijfskundig medewerkers.

In de verzorgende en dienstverlenende beroepsklasse werken negen van de tien werkenden in een beroepsgroep waarvoor grote tekorten verwacht worden. De grote knelpunten hangen deels samen met de toename van de werkgelegenheid in zorg en welzijn. De knelpunten zijn zeer groot voor ziekenverzorgenden, maar ook voor vakkenvullers, interieurverzorgers, verkopers, hulpkrachten horeca en verzorging, verzorgend personeel en bedrijfshoofden horeca worden grote knelpunten in de personeelsvoorziening verwacht.

In de openbare orde- en veiligheidsberoepen zullen zich naar verwachting enige knelpunten voordoen in de personeelsvoorziening. Ruim 58\% van het personeel in deze beroepsklasse werkt in een beroepsgroep waarvoor grote knelpunten verwacht worden. Werkgevers kunnen grote moeilijkheden verwachten bij de werving van aspi- 
rant politieagenten, soldaten en beveiligingshulpkrachten, brandweerlieden, politieinspecteurs en officieren.

\subsection{Conclusies}

Tussen 2006 en 2010 is de arbeidsmarktsituatie voor schoolverlaters op een aantal punten verslechterd. De verslechtering van de arbeidsmarktsituatie kan onder meer afgelezen worden aan de toename van de werkloosheid onder schoolverlaters van gemiddeld $6,5 \%$ in 2006 naar bijna $8 \%$ in 20 Io, en aan de daling van het reële bruto maandloon. Tevens moeten in 2010 meer schoolverlaters genoegen nemen met een deeltijdbaan of een flexibel contract en steeg het percentage schoolverlaters met spijt van de gevolgde opleiding enigszins. Positief is dat in dezelfde periode iets minder schoolverlaters onder hun niveau of buiten hun vakrichting zijn gaan werken.

Voor de komende jaren worden er afhankelijk van de opleidingsachtergrond uiteenlopende arbeidsmarktperspectieven verwacht voor jongeren die in de periode 20II-20I6 de arbeidsmarkt betreden. Voor I2 van de 23 opleidingscategorieën zijn de verwachte perspectieven voor schoolverlaters goed, voor de andere helft redelijk of matig. Op elk opleidingsniveau zijn er opleidingen met goede en minder goede toekomstige arbeidsmarktperspectieven. Duidelijk is verder dat de komende jaren een verslechtering kan worden verwacht van de arbeidsmarktsituatie voor schoolverlaters met een diploma economie, ongeacht het opleidingsniveau. Daar staat tegenover dat de toekomstige arbeidsmarktperspectieven voor schoolverlaters in de technische richting goed zijn. Dit geldt eveneens voor gediplomeerden met een zorgopleiding. Voor WO medisch zijn de arbeidsmarktperspectieven het best door de verwachte toename van de werkgelegenheid in combinatie met een hoge vervangingsvraag. Ongeschoolden zullen de komende jaren de meeste moeite hebben om aan het werk te komen, hetgeen verklaard kan worden door de grote instroom ten opzichte van de baanopeningen.

De vraag- en aanbodontwikkelingen komen eveneens tot uiting in de beloning van werknemers uit de verschillende beroepsklassen. Werknemers in de medische en paramedische beroepen, economische-administratieve beroepen en informaticaberoepen kregen een hoog gemiddeld bruto uurloon in 2008. Deze beroepen vertoonden ook een relatief sterke loongroei tussen $200 \mathrm{I}$ en 2008 . Werknemers in de agrarische beroepen en de verzorgende en dienstverlenende beroepen verdienden in 2008 het minst en de loonontwikkeling in deze beroepen was negatief in de jaren ervoor. Ook binnen de beroepsklassen is gekeken naar de beloning van werknemers. De meestverdienende werknemers binnen een beroepsklasse verdienden in 2008 bijna drie keer zo veel dan de minstverdienenden. Daarnaast blijkt dat de loonongelijkheid binnen beroepen met $\mathrm{I} 2 \%$ is toegenomen tussen $200 \mathrm{I}$ en 2008 .

De toekomstige knelpunten in de personeelsvoorziening voor werkgevers zijn het grootst als zij personeel willen werven met een technische of zorgopleiding. Er zullen tot 
2016 over het algemeen weinig wervingsproblemen zijn bij het aantrekken van personeel met een economische achtergrond. In de zorgsector zijn de knelpunten vooral gerelateerd aan de grote uitbreidingsvraag die verband houdt met de toenemende behoefte aan zorg. Dit geldt voor alle opleidingsniveaus. Op VMBO- en WO-niveau wordt dit effect versterkt door een hoge vervangingsvraag, en voor VMBO ook nog eens door een lage instroom vanuit het onderwijs op de arbeidsmarkt. Zeer groot zijn de knelpunten in de personeelsvoorziening bij het aantrekken van verpleeghulpen en leerling-verpleegkundigen, verplegenden en doktersassistenten, therapeuten en verpleegkundigen, artsen en medisch analisten. Bij de lagere verzorgende en dienstverlenende beroepen ontstaan zeer grote knelpunten bij het werven van ziekenverzorgenden. Binnen de technische en industrieberoepen worden over het algemeen zeer grote knelpunten verwacht bij het werven van technisch analisten, werktuigbouwkundigen, weg- en waterbouwkundigen en grafische vakkrachten.

Ook voor een aantal beroepen op andere segmenten van de arbeidsmarkt worden grote knelpunten in de personeelsvoorziening verwacht. Binnen de pedagogische beroepen zijn de knelpunten groot voor leraren basisonderwijs, docenten exacte, medische en verzorgende vakken (2e graads), docenten exacte, medische en verzorgende vakken (Ie graads en WO), docenten landbouw en techniek (2e graads), docenten talen en expressie, docenten letteren (Ie graads en WO), docenten ze graads zonder specialisatie, zweminstructeurs en onderwijskundigen en pedagogen. Binnen de agrarische beroepen zal het moeilijk worden om voldoende agrarische vakkrachten, milieuhygiënisten en agrarisch vertegenwoordigers en agrarische bedrijfshoofden te vinden. 


\section{Het belang van deeltijdwerk: omvang, gevolgen en mogelijk- heden van 'opplussen'}

\subsection{Inleiding}

Nederland staat internationaal gezien bekend als het deeltijdland: nergens anders wordt zoveel in deeltijd gewerkt. Ook de kwaliteit van deeltijdbanen is in Nederland veel hoger dan in andere landen, zoals Duitsland, Engeland en de Verenigde Staten. In hoofdstuk 3 wordt deeltijdwerk onder schoolverlaters bezien vanuit het oogpunt van een verborgen discrepantie, dat wil zeggen een gebrekkige aansluiting met de arbeidsmarkt. Dit komt doordat het voor schoolverlaters van belang is dat zij snel relevante arbeidsmarkt ervaring opbouwen, hetgeen beter lukt naarmate de aanstellingsomvang groter is. Deeltijdarbeid onder de volwassen beroepsbevolking dient echter ook andere doelen; zo maakt deeltijdwerk het bijvoorbeeld voor vouwen gemakkelijker om arbeid met zorgtaken te combineren. De keerzijde van deeltijdarbeid is dat het nadelig kan zijn voor de opbouw van menselijk kapitaal. Er is dan ook vanuit het beleid veel belangstelling voor deeltijdarbeid. Zo heeft in 2010 de 'Taskforce deeltijdplus', in opdracht van de regering, onderzoek gedaan naar de mogelijkheden om voornamelijk vrouwen met kleine deeltijdbanen meer uren te laten werken. Een belangrijke reden voor de overheid om zich hier voor in te zetten, zijn de te verwachte tekorten op de arbeidsmarkt als gevolg van de hoge verwachte vervangingsvraag.

Dit hoofdstuk geeft een overzicht van de mate waarin in Nederland in deeltijd gewerkt wordt. Bovendien worden de gevolgen van deeltijdwerk voor de kennisontwikkeling en productiviteit besproken, en de mogelijkheden die uitbreiding van het aantal gewerkte uren, i.e. het 'opplussen' van deeltijdbanen, bieden voor het verlichten van tekorten op de arbeidsmarkt. In paragraaf 4.2 wordt ingegaan op de ontwikkeling van deeltijdwerk op de verschillende segmenten van de arbeidsmarkt. Er wordt gekeken naar de gemiddelde werkweek per bedrijfssector en opleidingscategorie in de afgelopen decennia. In de paragrafen 4.3 en 4.4 worden twee consequenties van deeltijdwerk geanalyseerd. In paragraaf 4.3 wordt gekeken hoe de ontwikkeling van het menselijk kapitaal - in de vorm van het volgen van formele trainingen en informeel 
leren - wordt beïnvloed door het werken in deeltijd. Vervolgens wordt in paragraaf 4.4 ingegaan op de rol van deeltijdwerk voor de productiviteit van bedrijven. In paragraaf 4.5 wordt gekeken in hoeverre het opplussen van deeltijdwerk kan bijdragen aan het verminderen van de verwachte knelpunten in de personeelsvoorziening voor werkgevers. Er worden daarbij vijf verschillende scenario's gepresenteerd. Paragraaf 4. 6 bevat de conclusies van dit hoofdstuk en enkele beleidsaanbevelingen.

\subsection{Ontwikkeling van deeltijdwerk}

In tegenstelling tot eerdere hoofdstukken worden in dit hoofdstuk alle werkenden bij de analyses in beschouwing genomen, ongeacht het aantal gewerkte uren. Dat betekent dat personen die minder dan I2 uur per week werken, zoals bijvoorbeeld scholieren, worden meegenomen bij het onderscheid tussen kleine en grote deeltijdbanen. Kleine deeltijdbanen zijn banen van minder dan 24 uur per week. Grote deeltijdbanen zijn banen van 24 tot en met 32 uur per week. Net als in hoofdstuk 3 zijn voltijdbanen gedefinieerd als banen van meer dan 32 uur per week, uitgaand van het aantal uren in het arbeidscontract. Eerst wordt een beeld geschetst van de ontwikkeling van deeltijdarbeid onder mannen en vrouwen in de afgelopen Is jaar. Daarna wordt gekeken naar de ontwikkeling van de gemiddelde werkweek gedifferentieerd naar opleiding.

\section{Figuur 4.1}

Verdeling van werkende mannen en vrouwen naar aanstellingsomvang tussen 1996 en 2010

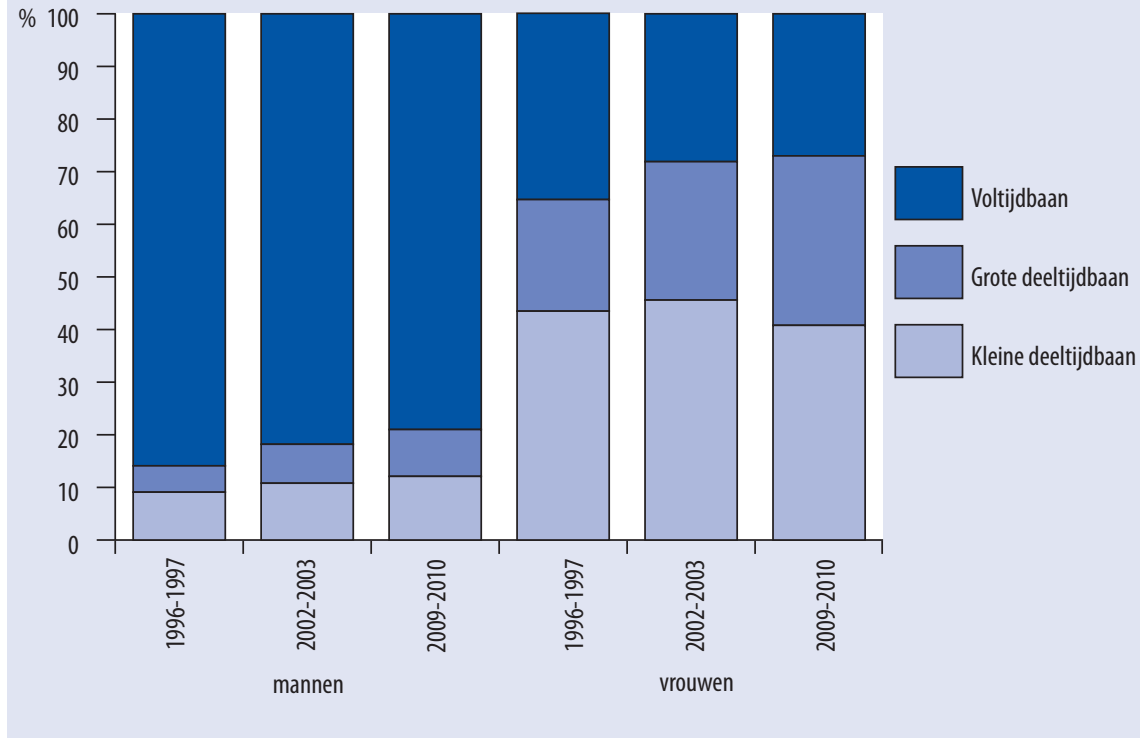

Bron: CBS(EBB) 
Figuur 4.I geeft de ontwikkeling in de verdeling tussen kleine deeltijdbanen, grote deeltijdbanen en voltijdbanen weer voor werkenden in de jaren 1996-1997, 20022003 en 2009-20I0. De figuur laat duidelijk zien dat zowel mannen als vrouwen in toenemende mate in deeltijd gaan werken. In diezelfde periode is het percentage voltijd werkende vrouwen eveneens gedaald, van 35\% naar 27\%. In 1996-1997 werkte $86 \%$ van de mannen voltijd. In 2009-20I0 is dit percentage gedaald naar 79 . Onder mannen zijn grote deeltijdbanen populairder geworden. In 1996-I997 werkte 5\% van de mannen in grote deeltijdbanen. In 2009-20Io is dit 9\%. Hoewel vrouwen vaker werkzaam zijn in kleine deeltijdbanen (4I\% in 2009-20IO), is het percentage vrouwen in grote deeltijdbanen toegenomen, net als bij mannen, namelijk van $21 \%$ naar $31 \%$ tussen 1996-1997 en 2009-20I0.

\section{Figuur 4.2}

Gemiddelde werkweek per bedrijfssector tussen 1996 en 2010

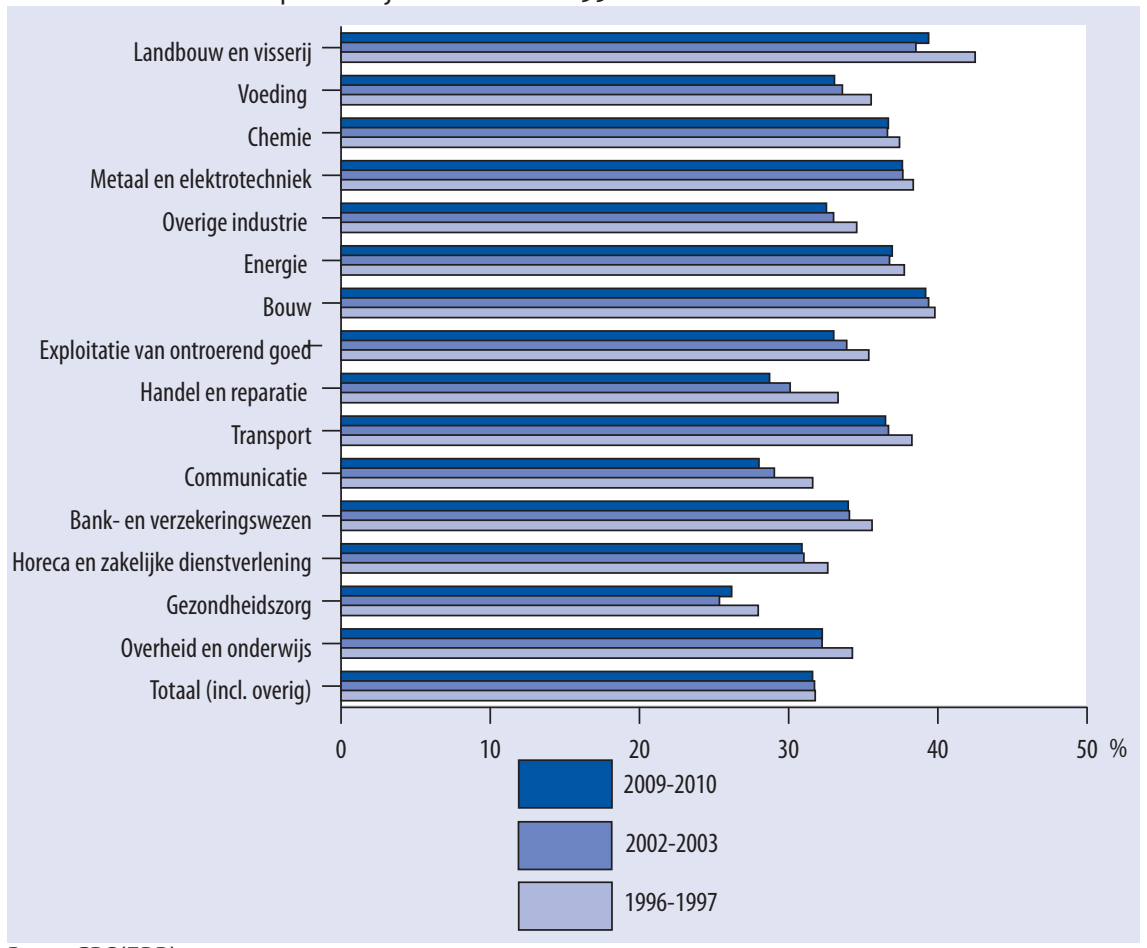

Bron: $\mathrm{CBS}(\mathrm{EBB})$

Figuur 4.2 laat de gemiddelde werkweek op drie momenten in de tijd zien. De figuur laat zien dat in alle bedrijfssectoren de gemiddelde werkweek groter was in 1996-1997 dan in de jaren erna. De gemiddelde werkweek in 2009-20Io is vrijwel gelijk aan die in 2002-2003. In een aantal bedrijfssectoren is de gemiddelde werkweek nog verder afgenomen. Verder blijkt dat de gemiddelde werkweek erg verschilt tussen bedrijfssectoren. In de gezondheidszorg is de gemiddelde werkweek sinds 2002-2003 slechts 25 uur, 
terwijl deze in de bouw en de landbouw en visserij bijna 40 uur is. Omdat in Nederland een contractuele werkweek maximaal 40 uur omvat, kan dit betekenen dat in de laatstgenoemde bedrijfssectoren vrijwel niemand in deeltijd werkt. Deze sectoren staan dan ook bekend als 'mannensectoren'. Ten slotte is het opmerkelijk dat in 6 van de I6 bedrijfssectoren de gemiddelde werkweek kleiner is dan 33 uur per week. Internationaal wordt een baan met minder dan 33 uur per week vaak gezien als een deeltijdbaan. De sectoren overheid en onderwijs, gezondheidszorg, horeca en zakelijke dienstverlening, communicatie, handel en reparatie en overige industrie kunnen daarom internationaal gezien vanaf 2002-2003 als deeltijdsectoren worden bestempeld.

\section{Figuur 4.3}

Gemiddelde werkweek per bedrijfssector tussen 1996 en 2010

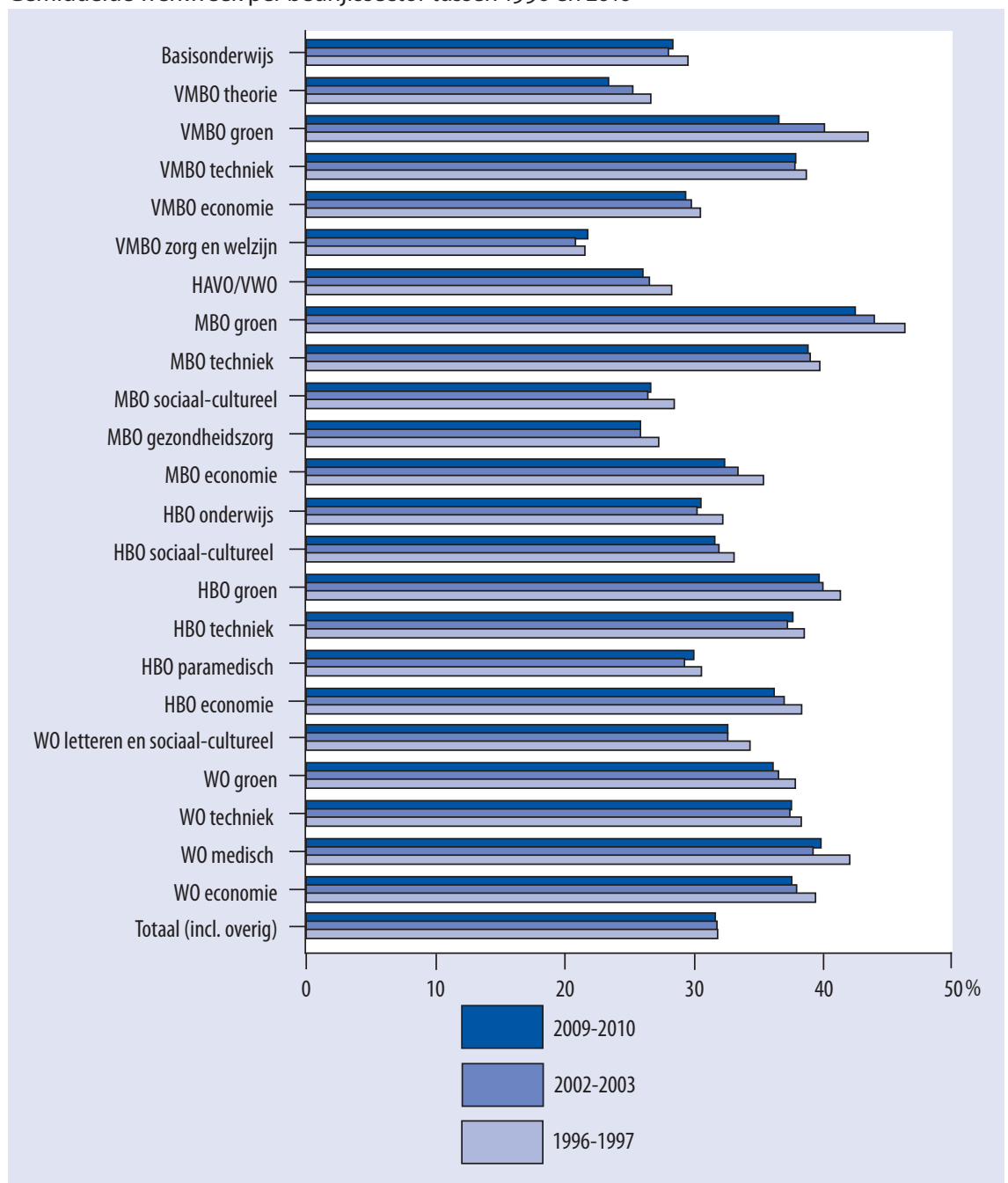

Bron: CBS(EBB) 
Verwacht kan worden dat het aantal uren dat mensen werken afhangt van hun opleidingsniveau. Hier wordt in figuur 4.3 naar gekeken. De figuur laat voor 28 opleidingscategorieën zien hoe de gemiddelde werkweek zich sinds I996-I997 heeft ontwikkeld. Zowel opleidingsniveau als -richting van werkenden blijkt een rol te spelen in het aantal gewerkte uren. Er is echter geen eenduidige relatie tussen het opleidingsniveau en de gemiddelde werkweek. Bij de techniekopleidingen is de gemiddelde werkweek onder alle opleidingsniveaus ongeveer gelijk (rond 38 uur per week). Binnen de opleidingsrichting economie geldt dat mensen met een HBO- of WO-opleiding beduidend meer uren per week werken dan mensen met een VMBO- of MBO-opleiding ( 37 tot 38 uur vergeleken met 30 uur per week). Deze positieve relatie tussen het opleidingsniveau en de gemiddelde werkweek geldt nog sterker binnen de opleidingen voor de zorg. Terwijl degenen met een WO-opleiding gericht op de gezondheidszorg gemiddeld ongeveer 40 uur per week werken, zijn werkenden met een opleiding HBO paramedisch iets minder dan 30 uur per week werkzaam. Binnen de opleidingscategorieën $\mathrm{MBO}$ gezondheidszorg en VMBO zorg en welzijn is de gemiddelde werkweek met respectievelijk 26 en 22 uur per week nog korter.

De verschillen in de gemiddelde werkweek voor opleidingen gericht op de gezondheidszorg lijken tevens samen te hangen met het geslacht van de werkenden. Terwijl vrouwen minimaal $85 \%$ uitmaken van de werkenden met een VMBO- of $\mathrm{MBO}$-opleiding gerelateerd aan de zorg, is dit percentage lager, namelijk $77 \%$, onder de werkenden met een zorgopleiding op HBO-niveau. Het percentage vrouwen onder werkenden met een medische opleiding op WO-niveau is nog lager, namelijk $45 \%$. Deze verdeling van vrouwen binnen de opleidingstypen voor de zorg, biedt een verklaring voor de positieve relatie tussen het opleidingsniveau en de gemiddelde werkweek.

Tabel 4.1

Top 10 opleidingstypen met het hoogste percentage werkenden in deeltijd, 2009-2010

\begin{tabular}{|c|c|c|c|c|}
\hline Opleidingstypen & $\begin{array}{c}\text { Aantal } \\
\text { werkenden }\end{array}$ & $\begin{array}{l}\text { gemiddelde } \\
\text { werkweek } \\
\text { in uren }\end{array}$ & $\begin{array}{l}\text { \% werkenden } \\
\text { in een kleine } \\
\text { deeltijdbaan }\end{array}$ & $\begin{array}{c}\% \text { werkenden } \\
\text { in een grote } \\
\text { deeltijdbaan }\end{array}$ \\
\hline 1. $\mathrm{MBO}$ verzorging & 260.000 & 23,4 & 50 & 33 \\
\hline 2. VMBO (uiterlijke) verzorging & 219.500 & 21,8 & 57 & 25 \\
\hline 3. MBO dokters-, tandarts-, en dierenartsassistent & 39.500 & 24,6 & 46 & 35 \\
\hline 4. $M B O$ verpleging & 123.500 & 25,5 & 38 & 40 \\
\hline 5. MBO apothekersassistent & 25.000 & 25,0 & 42 & 36 \\
\hline 6. MB0 sociaal-pedagogisch en welzijn & 160.500 & 26,5 & 33 & 39 \\
\hline 7. MBO secretariaat & 109.000 & 26,6 & 36 & 35 \\
\hline 8. MBO uiterlijke verzorging & 87.500 & 27,0 & 39 & 30 \\
\hline 9. HBO lerarenopleiding medisch en verzorging & 15.000 & 27,7 & 31 & 36 \\
\hline 10. HBO verpleegkunde & 82.000 & 28,9 & 24 & 43 \\
\hline
\end{tabular}


In de top ro van de opleidingstypen met het hoogste deeltijdpercentage is meestal meer dan $80 \%$ van de werkenden van het vrouwelijke geslacht. Uit tabel 4.I blijkt dat de gemiddelde werkweek bij de opleidingstypen in de top Io tussen de 22 en 29 uur per week ligt. Bij twee opleidingstypen ligt het percentage werkenden dat een kleine deeltijdbaan heeft zelfs op minstens 50\%, namelijk MBO verzorging en $\mathrm{VMBO}$ (uiterlijke) verzorging. Met uitzondering van $\mathrm{HBO}$ lerarenopleiding medisch en verzorging en $\mathrm{HBO}$ verpleegkunde, is het niveau van alle opleidingstypen in de top Io $\mathrm{MBO}$ of lager. Dit bevestigt het beeld in figuur 4.3 dat vooral de lagere en middelbare zorgopleidingen een kleine gemiddelde werkweek hebben.

\subsection{Gevolgen van deeltijdwerk voor werkenden}

De economische literatuur over deeltijdwerk richt zich met name op de gevolgen van deeltijdwerk op het loon dat men verdient en de kans op (neerwaartse) baanmobiliteit. In landen als de Verenigde Staten, het Verenigd Koninkrijk en Duitsland, is het uurloon van mensen met een deeltijdbaan vaak lager dan het uurloon van mensen met een vergelijkbare voltijdbaan. Dit verschil in uurloon wordt weliswaar kleiner naarmate men rekening houdt met persoons- en bedrijfsfactoren, maar een klein verschil blijft bestaan. ${ }^{66}$ In Nederland wordt deze zogenaamde 'part-time wage gap' niet gevonden. ${ }^{67}$ Dit is waarschijnlijk toe te schrijven aan een geheel andere deeltijdcultuur in Nederland. In Nederland zijn de deeltijdbanen qua arbeidsvoorwaarden over het algemeen niet slechter dan voltijdbanen. Dit is mede het gevolg van twee wetten gerelateerd aan deeltijdwerk: de Wet gelijke behandeling en de Wet aanpassing arbeidsduur, die werknemers het recht tot vermindering in contracturen geeft.

Binnen de internationale literatuur wordt de 'part-time wage gap' vaak toegeschreven aan een relatief lagere hoeveelheid menselijk kapitaal. ${ }^{68}$ Dit wordt in de theorie van het menselijk kapitaal verklaard door de geringere bereidheid van zowel de werknemer als de werkgever om te investeren in het menselijk kapitaal van deeltijders. Investeren in menselijk kapitaal kan door het volgen van een training, of door het uitvoeren van taken waarvan men kan leren. In beide gevallen is de werknemer dan minder productief omdat hij zich niet (volledig) in kan zetten voor de productie. De werkgever mist daarom een deel van zijn omzet. De werknemer kan hierdoor tijdelijk een lager loon krijgen en of investeert zijn vrije tijd. Hoe meer uren per week werkt, hoe groter de voordelen van het investeren in de toekomst. Voor de werknemer bestaan de voordelen uit een hoger uurloon en wellicht uit betere carrièremogelijkheden. Voor de werkgever bestaan de voordelen uit een hogere productiviteit. Omdat de voordelen

66. Zie bijvoorbeeld B. Hirsch (2005), 'Why do part-time workers earn less? The role of worker and job skills', Industrial and Labor Relations Review, Vol. 58, pp. 252-55I.

67. R. Euwals en M. Hogerbrugge (2004), Explaining the growth of part-time employment. Factors of supply and demand, CPB Discussion Paper No 3I, Den Haag.

68. Een ander vaak genoemde reden is een lagere betrokkenheid met de arbeidsmarkt. 
van het investeren groter zijn naarmate een werknemer meer uren per week werkt, zullen voltijders over het algemeen vaker deelnemen aan cursussen dan deeltijders.

\section{Tabel 4.2}

Trainingsparticipatie van voltijders en deeltijders per bedrijfssector, 2009-2010

\begin{tabular}{lccc} 
& Voltijdbaan & Grote deeltijdbaan & Kleine deeltijdbaan \\
\hline Landbouw en visserij & $\%$ & $\%$ & $\%$ \\
\hline Voeding & 3,6 & 4,1 & 1,6 \\
\hline Chemie & 7,6 & 1,9 & 1,6 \\
\hline Metaal en electrotechniek & 9,1 & 5,7 & 2,3 \\
\hline Overige industrie & 7,7 & 3,0 & 1,8 \\
\hline Energie & 4,4 & 4,8 & 2,1 \\
\hline Bouw & 13,0 & 7,8 & 2,9 \\
\hline Onroerend goed & 6,2 & 2,0 & 3,5 \\
\hline Handel en reparatie & 9,7 & 9,6 & 1,8 \\
\hline Transport & 5,7 & 4,8 & 4,3 \\
\hline Communicatie & 7,0 & 6,0 & 0,8 \\
\hline Bank - en verzekeringswezen & 11,6 & 5,9 & 12,0 \\
\hline Horeca en zakelijke dienstverlening & 19,9 & 18,3 & 2,5 \\
\hline Gezondheidszorg & 8,7 & 5,8 & 6,3 \\
\hline Overheid en onderwijs & 9,5 & 9,4 & 6,5 \\
\hline Bron & 11,5 & 9,4 & \\
\hline
\end{tabular}

Bron: CBS(EBB)

- : te weinig waarnemingen

Opmerking: Trainingsparticipatie is gedefinieerd als het percentage mensen in een bedrijfssector dat op dit moment of in de afgelopen 4 weken een training van minder dan 6 maanden heeft gevolgd of afgerond.

In tabel 4.2 en 4.3 is het investeringsgedrag van vol- en deeltijders in kaart gebracht. Tabel 4.2 laat per bedrijfssector het percentage werkenden zien dat een training heeft gevolgd. Trainingsparticipatie wordt hier gedefinieerd als het percentage werkenden in een bedrijfssector dat op het moment van het interview of in de vier weken daarvoor, een training van minder dan 6 maanden heeft gevolgd of afgerond. Deze percentages zijn apart vermeld voor voltijders, en werkenden met een grote en een kleine deeltijdbaan. Op deze manier kan worden nagegaan of het trainingsgedrag van werkenden binnen een bepaalde bedrijfssector afhankelijk is van hun contractuele werkuren. ${ }^{69}$ Het algemene beeld dat deze tabel geeft is in lijn met de verwachtingen van de theorie van het menselijk kapitaal. De kans dat voltijders een training volgen is over het algemeen groter dan de kans dat werkenden met een grote deeltijdbaan een training volgen. Werkenden in een kleine deeltijdbaan volgen het minst vaak training.

69. In deze tabel betreft het beschrijvende statistieken en is er dus geen rekening gehouden met eventuele verschillen in persoons- en bedrijfskenmerken. 
In sommige sectoren is de kans op trainingsparticipatie onder voltijders en werkenden met een grote deeltijdbaan ongeveer even groot. De kans op het volgen van een training onder werkenden met een kleine deeltijdbaan is in deze sectoren veel kleiner. Dit geldt voor bijvoorbeeld de sectoren landbouw en visserij, overige industrie, handel en reparatie, bank- en verzekeringswezen en gezondheidszorg. In andere sectoren, zoals voeding en metaal en elektrotechniek, is de kans op trainingsparticipatie onder de twee soorten deeltijders juist ongeveer even groot, maar wel veel kleiner dan de kans op trainingsparticipatie onder voltijders. In sectoren zoals de horeca en zakelijke dienstverlening en energie neemt de kans op het volgen van een training toe met het aantal contract-uren per week.

In tabel 4.3 wordt weergegeven hoeveel procent voltijders en deeltijders in de verschillende bedrijfssectoren besteden aan taken waarvan zij kunnen leren. ${ }^{70}$ Deze vorm van leren wordt informeel leren genoemd. Als voltijders en deeltijders een even groot percentage werktijd besteden aan informeel leren, komen deeltijders nog steeds uit op een lagere investering in informeel leren omdat het totale aantal gewerkte uren lager is.

Tabel 4.3

Informeel leren per bedrijfssector, 2008

\begin{tabular}{|c|c|c|c|}
\hline & $\begin{array}{c}\text { Voltijdbaan } \\
\%\end{array}$ & $\begin{array}{l}\text { Grote deeltijdbaan } \\
\qquad \%\end{array}$ & $\begin{array}{c}\text { Kleine deeltijdbaan } \\
\%\end{array}$ \\
\hline Industrie & 22 & 18 & 13 \\
\hline Bouw & 27 & 38 & 16 \\
\hline Handel en horeca & 22 & 22 & 19 \\
\hline Vervoer & 19 & 21 & 7 \\
\hline Financiële en zakelijke dienstverlening & 30 & 28 & 21 \\
\hline Overige dienstverlening & 24 & 24 & 13 \\
\hline Openbaar bestuur & 30 & 31 & 14 \\
\hline Onderwijs & 31 & 29 & 25 \\
\hline Zorgen en welzijn & 30 & 32 & 21 \\
\hline
\end{tabular}

Bron: Arbeidsaanbodpanel (2008)

Opmerking: Informeel leren is gedefinieerd als het percentage van de werktijd besteed aan taken waarvan men kan leren.

Uit de tabel blijkt dat deeltijders inderdaad procentueel minder tijd besteden aan werkzaamheden waarvan ze leren dan voltijders. Voor de meeste bedrijfssectoren geldt echter dat het percentage van de werktijd waarin voltijders en werkenden met een grote deeltijdbaan informeel leren niet erg verschillend is. Dit geeft ook aan dat de kwaliteit van de banen van voltijders en werkenden met een grote deeltijdbaan wat

70. De gegevens zijn afkomstig uit het Arbeidsaanbodpanel. Het aantal respondenten van dit panel laat het niet toe om de uitkomsten naar bedrijfssector op een lager aggregatieniveau te presenteren. De gepresenteerde percentages zijn gebaseerd op relatief weinig observaties en moeten daarom met enige voorzichtigheid worden geïnterpreteerd. 
betreft de leermogelijkheden redelijk vergelijkbaar zijn. Werkenden met een kleine deeltijdbaan blijken daarentegen in de meeste bedrijfssectoren veel minder te leren op hun werk dan de voltijders of hun collega's met een grote deeltijdbaan. De enige uitzondering is de sector handel en horeca. Daar wordt onafhankelijk van de duur van de werkweek ongeveer $20 \%$ van de werktijd besteed aan taken waarvan men kan leren.

De gegevens in tabellen 4.2 en 4.3 laten zien dat deeltijders, overeenkomstig de verwachtingen vanuit de theorie van het menselijk kapitaal, inderdaad minder tijd besteden aan training en informeel leren. Daarbij doet zich de vraag voor of de deeltijders zelf minder bereid zijn om te investeren, of dat juist de werkgevers minder bereid zijn in hun deeltijders te investeren. In een studie van Nelen en De Grip (2009) wordt deze vraag beantwoord..$^{71}$ Aan de hand van een aantal regressieanalyses wordt bekeken of de determinanten van trainingsparticipatie verschillend zijn voor deeltijders en voltijders. In tabel 4.4 is een aantal van deze analyses opgenomen.

\section{Tabel 4.4}

Regressieresultaten van de determinanten van trainingsparticipatie van deeltijders en voltijders

\begin{tabular}{|c|c|c|c|c|}
\hline & \multicolumn{2}{|c|}{ Trainingsparticipatie } & \multicolumn{2}{|c|}{ Informeel leren } \\
\hline & Deeltijders & Voltijders & Deeltijders & Voltijders \\
\hline \multicolumn{5}{|l|}{ Psychologische kenmerken } \\
\hline Duidelijk beeld van verdere loopbaan & $0,099^{* * *}$ & 0,032 & $0,058^{* * *}$ & 0,009 \\
\hline Leermotivatie & $0,126^{* * *}$ & $0,051^{* *}$ & 0,012 & 0,018 \\
\hline \multicolumn{5}{|l|}{ Personeelsontwikkeling } \\
\hline Functioneringsgesprek & $0,192^{*}$ & $0,149^{* *}$ & $-0,001$ & $-0,026$ \\
\hline Persoonlijk opleidingsplan & 0,069 & $0,154^{* * *}$ & 0,05 & 0,024 \\
\hline Loopbaanplan & $-0,015$ & $-0,112^{*}$ & $-0,009$ & 0,02 \\
\hline \multicolumn{5}{|l|}{ High Performance Workplace } \\
\hline Teamwerk & 0,038 & 0,029 & 0,031 & $0,051^{*}$ \\
\hline Zelfstandigheid & $-0,017$ & $-0,003$ & $-0,012$ & 0,004 \\
\hline Prestatiebeloning & $-0,167$ & $0,088^{*}$ & $-0,025$ & $-0,01$ \\
\hline \multicolumn{5}{|l|}{ Feedback } \\
\hline Positieve feedback & $-0,021$ & $-0,015$ & $-0,004$ & $0,041^{* * *}$ \\
\hline Kritische feedback & 0,043 & $-0,019$ & $0,033^{*}$ & $0,031^{* *}$ \\
\hline
\end{tabular}

Bron: Nelen en De Grip (2009)

Opmerking: ${ }^{*}=$ significant op $10 \%$-niveau; ${ }^{* *}=$ significant op $5 \%$-niveau; ${ }^{* *}=$ significant op 1\%-niveau

7I. A. Nelen en A. de Grip (2009), 'Why do part-time workers invest less in human capital than fulltimers', Labour, Vol. 23, pp. 6I-83. In dat onderzoek zijn de analyses uitgevoerd met 2SLS regressieanalyses. De tabel geeft de marginale effecten van de tweede stap weer in procenten. Enkelvoudige regressieanalyses, waarin investeringen verklaard worden door de psychologische kenmerken en het personeelsbeleid, zouden onjuiste resultaten kunnen opleveren wanneer deeltijders voor een deeltijdbaan hebben gekozen omdat ze niet graag investeren in hun menselijk kapitaal. De auteurs geven een uitgebreide methodologische uitleg gegeven hoe met dit endogeniteitsprobleem wordt omgegaan. 
Tabel 4.4 geeft een overzicht van de factoren die van invloed zijn op de investeringen in het menselijk kapitaal van deeltijders en voltijders. Ook hier wordt onderscheid gemaakt tussen trainingsparticipatie, als een vorm van formeel leren, en informeel leren. Bij deeltijders zijn de psychologische kenmerken bepalend voor het al dan niet volgen van een training of cursus. Daarbij gaat het om zowel de leermotivatie als het beeld dat men heeft van de verdere loopbaan. Hoewel iemands leermotivatie ook bij voltijders een positief effect heeft op de trainingsdeelname, is het effect bij hen drie keer zo klein als bij de deeltijders. Daarentegen bevordert het personeelsbeleid van werkgevers alleen bij voltijd werkenden de cursus- en trainingsdeelname. Daarbij blijkt name het beleid dat expliciet gericht is op de personeelsontwikkeling de scholingsinvesteringen van voltijders vergroot. Zowel door functioneringsgesprekken als door persoonlijke opleidingsplannen neemt de deelname aan cursussen en trainingen bij de in voltijd werkenden met $15 \%$ toe. Uit de tabel komt het beeld naar voren dat de drijfveer voor deeltijders om cursussen en trainingen te volgen vooral vanuit henzelf komt, terwijl de voltijders gestimuleerd worden door hun werkgever.

Het informele leren van de deeltijders wordt echter niet beïnvloed door hun leermotivatie. Wel blijkt dat ze meer tijd besteden aan werkzaamheden waarvan ze leren als ze een beter beeld hebben van hun verdere loopbaan. Voor voltijders hebben beide psychologische factoren geen invloed op de mate waarin zij informeel leren. Hoewel het personeelsontwikkelingsbeleid van de werkgever voor de deeltijders noch de voltijders van belang lijkt te zijn voor het informele leren, hebben de leidinggevenden wel degelijk een positief effect op het informele leren van voltijders. Het geven van positieve en kritische feedback maakt dat voltijders tijdens hun werk meer leren. Voltijders die regelmatig positieve of kritische feedback krijgen, besteden respectievelijk $4 \%$ en $3 \%$ meer tijd aan leerzame werkzaamheden. Deeltijders profiteren daarentegen niet van dit positieve effect van positieve en kritische feedback.

Het personeelsbeleid van de werkgever is de grootste drijfveer voor de investeringen in het menselijk kapitaal van de voltijds werkenden. Hoewel de leermotivatie ook een rol speelt, wordt hun deelname aan trainingen en cursussen voornamelijk beïnvloed door het personeelsontwikkelingsbeleid van het bedrijf waar ze werken. Het informele leren van voltijders wordt zelfs alleen maar door het werkgeversbeleid gestimuleerd. Daarbij wordt de trainingsparticipatie met name gestimuleerd door positieve en kritische feedback van de werkgever. Voor deeltijders is de situatie geheel anders. Zij worden niet door het personeelsbeleid van hun werkgever gestimuleerd tot meer formeel of informeel leren. Deeltijders kunnen dit slechts gedeeltelijk compenseren wanneer zij zeer gemotiveerd zijn om te leren en een goed beeld hebben van hun verdere loopbaan. Het achterblijven van de investeringen in het menselijk kapitaal van deeltijders betekent dat zij het risico lopen dat hun arbeidsmarktpositie op termijn verslechtert. Dit zal vooral het geval zijn als zij werkzaam zijn in een dynamische sector. 


\subsection{Gevolgen van deeltijdwerk voor bedrijven}

In tegenstelling tot al het onderzoek naar de gevolgen van deeltijdwerk voor werkenden, is er weinig onderzoek gedaan naar de gevolgen van deeltijdwerk voor bedrijven. In deze paragraaf wordt ingegaan op de vraag welke invloed het werken met deeltijders heeft op de bedrijfsproductiviteit. Op grond van de theorie van het menselijk kapitaal kan verwacht worden dat deeltijders per gewerkt uur minder productief zijn dan voltijders, omdat er minder in de kennis en vaardigheden van deeltijders wordt geïnvesteerd. Toch hoeft dit niet te betekenen dat bedrijven met veel deeltijders minder productief zijn dan bedrijven met minder deeltijders. Owen (1978) geeft bijvoorbeeld aan dat bedrijven die langer open zijn dan 40 uur per week baat hebben bij deeltijders, omdat hierdoor elkaar overlappende dienstroosters vermeden kunnen worden. ${ }^{72}$ Ook geeft Owen aan dat het vooral voordelig is om deeltijders in te zetten als er gedurende de openingstijden fluctuaties zijn in het aantal klanten dat geholpen moet worden. Op deze manier kan het aantal mensen dat werkt op een bepaald tijdstip afhankelijk zijn van de verwachte klandizie: tijdens piekuren kunnen dan meer mensen ingezet worden dan op momenten waarop weinig klanten verwacht worden. Daardoor wordt vermeden dat werknemers weinig te doen hebben als de vraag naar dienstverlening laag is. ${ }^{73}$ Het in dienst hebben van deeltijders kan er dus voor zorgen dat bedrijven hun personeel efficiënter kunnen inzetten. Of bedrijven daardoor ook productiever zijn blijft een empirisch vraagstuk.

Arvantis (2005) analyseert of bedrijven die aangeven deeltijdwerk belangrijk te vinden, productiever zijn dan bedrijven waarbinnen deeltijdwerk als niet belangrijk ervaren wordt. ${ }^{74} \mathrm{Hij}$ vindt een negatieve relatie tussen het belang dat aan deeltijdwerk wordt gehecht en de verkoopcijfers van een bedrijf. Pérotin en Robinso (2000) relateren het percentage deeltijders aan de productiviteit zoals deze wordt geschat door de manager. $^{75} \mathrm{Zij}$ vinden geen significant verband. Dit zou echter kunnen komen door de onnauwkeurige maatstaf van productiviteit. Voor het uitvoeren van goed onderzoek naar de relatie tussen deeltijdwerk en bedrijfsproductiviteit moet er dus een duidelijke en harde maatstaf van productiviteit zijn. Bovendien is er is volledige informatie nodig over het aantal werkuren van alle medewerkers in het bedrijf, en dienen de bedrijven die geanalyseerd worden sterk op elkaar te lijken. Daarom is het noodzakelijk dat de analyse zich richt op één sector waarin de werknemers qua opleidingsachtergrond en de bedrijven qua productietechnieken of dienstverleningsconcepten niet veel van elkaar verschillen.

72. J. Owen (1978), Working Hours: An Economic Analysis, Canada, Toronto, Lexington.

73. V. Mabert en M. Showalter (I990), 'Measuring the impact of part-time workers in service organisations', Journal of Operations Management, Vol. 9, pp. 209-229.

74. S. Arvantis (2005), 'Modes of labor flexibility at firm level: Are there any implications for performance and innovation? Evidence for the Swiss economy', Industrial and Corporate Change, Vol. I4, pp. 993-IOI6.

75. A. Pérotin en A. Robinso (2000), 'Employee participation and equal opportunities practices: Productivity effect and potential complementarities', British Journal of Industrial Relations, Vol. 38, pp. $557-583$. 
Nelen, De Grip en Fouarge (20II) gebruiken een dataset van de Nederlandse apotheekbranche die aan de genoemde eisen voldoet. ${ }^{76}$ Binnen de sector dient het aantal uitgeschreven receptregels als een goede maatstaf voor bedrijfsproductiviteit. ${ }^{77}$ Het pensioenfonds van de sector heeft volledige inzage gegeven in de contractuele werkuren van alle werknemers binnen de sector. 70\% van deze werknemers zijn apothekersassistent. Zij hebben allemaal dezelfde opleiding gevolgd, omdat in Nederland apothekersassistenten een $\mathrm{MBO}$-opleiding tot apothekersassistent op niveau 4 gevolgd moeten hebben. Bovendien is meer dan $98 \%$ van de apothekersassistenten vrouw. Het werknemersbestand binnen deze sector is dus heel homogeen. Omdat het een dienstensector betreft is de ingezette arbeid bovendien de belangrijkste productiefactor.

In de genoemde studie worden deeltijders gedefinieerd als werknemers die minder dan 24 uur per week werken. De focus ligt dus op kleine deeltijdbanen. Deze kleine deeltijdbanen zijn in de sector heel gebruikelijk: $42 \%$ van de werknemers in de apotheeksector werkt minder dan 24 uur per week. ${ }^{78}$ Uit de studie blijkt dat apotheken met een hoog percentage deeltijders productiever zijn dan apotheken met een hoog percentage voltijders. Dit resultaat wordt niet toegeschreven aan verschillen in de individuele productiviteit tussen deeltijders en voltijders, maar aan de meer efficiënte inzet van personeel in de apotheken met veel deeltijders. Apotheken blijken gemiddeld so uur per week open te zijn, terwijl een voltijdse aanstelling in deze sector 36 uur per week bedraagt. Dit betekent dat het niet efficiënt is om alleen voltijders aan te stellen. Uit aanvullende data, waaruit de werkroosters van apothekersassistenten van 900 bedrijven bekend zijn, blijkt dat deeltijders op een andere manier worden ingezet dan voltijders. Deeltijders werken zowel minder dagen per week als minder uren per werkdag. Ook blijkt dat deeltijders het mogelijk maken dat voltijds werkende collega's een lunchpauze hebben zonder dat de apotheek in de middagpauze moet sluiten.

Deze onderzoeksresultaten zijn niet vanzelfsprekend geldig voor bedrijven in alle branches. Veel ondernemingen in de dienstensectoren hebben echter soortgelijke kenmerken als de apotheken, waardoor ook daar de inzet van deeltijdwerkers efficiënt kan zijn. Behalve dat bij veel ondernemingen het aantal uren volgens de openingstijden groter is dan de contractuele arbeidsduur van voltijders, zijn schommelingen in de vraag naar diensten gedurende de dag of week een veelvoorkomend kenmerk bij dienstverlenende ondernemingen. In restaurants en supermarkten is er bijvoorbeeld sprake van piekuren die goed opgevangen kunnen worden door deeltijders. Maar ook in ondernemingen met lange werkdagen en winkels die zowel overdag als 's avonds open zijn, kan het gebruik van deeltijders efficiënt zijn.

76. A. Nelen, A. De Grip en D. Fouarge (201I), Is part-time employment beneficial for firm productivity?, IZA DP No 5423, Bonn.

77. De vergoedingen die de apotheek krijgt voor de geleverde medicijnen is ook gebaseerd op het aantal verwerkte receptregels.

78. In Nederland werkt de helft de vrouwen met betaald werk minder dan 24 uur per week. 


\section{5 'Opplussen' van deeltijdbanen}

De door de overheid ingestelde 'Taskforce deeltijdplus' concludeert in haar eindrapport dat er voor de handhaving van onze welvaart op hetzelfde niveau op korte termijn veel handen en hersens nodig zijn om de vrijkomende vacatures in te vullen. ${ }^{79}$ Daarbij wijst de Taskforce vooral op de verwachte personeelstekorten in de zorgsector. De Taskforce stelt dat een verhoogde arbeidsmarktparticipatie van vrouwen hiervoor essentieel is. De Taskforce denkt vooral aan het vergroten van het aantal uren van mensen met een deeltijdbaan. Vaak wordt dit aangeduid als het opplussen van deeltijdbanen. In deze paragraaf wordt eerst de invloed van opplusscenario's op de voor 2016 verwachte knelpunten in de personeelsvoorziening voor werkgevers besproken. ${ }^{8 \circ}$ Eerst worden per opleidingsniveau de verwachte tekorten aangegeven. Vervolgens wordt gekeken naar het effect van de opplusscenario's op de omvang van de verwachte tekorten. Daarbij wordt alleen rekening gehouden met de directe effecten van het opplussen op de verlichting van de arbeidsmarkttekorten. ${ }^{8 \mathrm{I}}$ Er wordt vooral gekeken naar de opleidingstypen met de hoogste verwachte personeelstekorten en wat het effect is van de opplusscenario's voor deze opleidingstypen.

De volgende 5 opplusscenario's worden onderscheiden:

I. Het opplussen van de kleine deeltijdbanen: iedereen met een kleine deeltijdbaan gaat 24 uur werken $(\geq 24)$.

II. De gemiddelde werkweek van mensen met een kleine deeltijdbaan gaat met vier uur (een halve dag) omhoog $(+4 \mathrm{kl})$.

III. De gemiddelde werkweek van mensen met een grote deeltijdbaan gaat met vier uur (een halve dag) omhoog (+4 gr).

IV. Vrouwen gaan gemiddeld evenveel werken als de mannen met dezelfde opleidingsachtergrond $(\mathrm{v}=\mathrm{m})$.

V. Deeltijders die meer uren willen werken gaan het door hen gewenste aantal uren werken $(+$ gew $)$.

In tabel 4.5 is te zien in welke mate het mogelijk is om de verwachte tekorten per opleidingsniveau terug te dringen. De verwachte tekorten zijn gebaseerd op de arbeidsmarktprognoses voor de periode $201 \mathrm{II}-20 \mathrm{O} 6$ in dit rapport. ${ }^{82}$ De vijf kolommen onder de scenario's geven de percentages weer waarmee de personeelstekorten voor werkgevers in de bovengenoemde vijf scenario's worden weggewerkt. Bij de berekeningen wordt uitgegaan van de gemiddelde werkweek in 2009-20I0. De tekorten zijn bijna

79. Taskforce DeeltijdPlus (2010), De discussie voorbij, Eindrapport Taskforce DeeltijdPlus, Amsterdam.

8o. Andere gevolgen van het opplussen kunnen zijn dat de productiviteit van personen en bedrijven afnemen en dat men minder tijd besteed aan mantelzorg en vrijwilligerswerk. Zie bijvoorbeeld Nelen, De Grip en Fouarge (20II), op. cit.; R. Dekker, D. Fouarge en T. Schils (2008), 'Concurrentie tussen arbeidsmarktparticipatie en maatschappelijke participatie', Economisch Statistische Berichten, Vol. 93, pp. 404-407.

8I. Indirecte effecten, op grond van bijvoorbeeld de toegenomen koopkracht of de door het opplussen veranderde gemiddelde arbeidsproductiviteit, worden niet meegenomen in de berekening.

82. De algemene en overige opleidingen zijn op elk opleidingsniveau buiten beschouwing gelaten. 
vanzelfsprekend het grootst onder de MBO'ers omdat zij de grootste groep vormen op de arbeidsmarkt, en het kleinst voor personen met een universitaire opleiding. De term 'tekorten' moet overigens niet al te letterlijk worden genomen. De tekorten dienen geïnterpreteerd te worden als fricties op de arbeidsmarkt, die op meerdere manieren kunnen worden opgelost. Dat gaat gepaard met zogenaamde aanpassingskosten, zoals bij de pogingen om uren op te plussen, of met bijvoorbeeld loonstijgingen voor de opleidingen waarvoor de arbeidsvraag groter is dan het arbeidsaanbod.

\section{Tabel 4.5}

Gevolgen van opplusscenario's voor de verwachte personeelstekorten naar opleidingsniveau, 20112016

\begin{tabular}{llcccc} 
Opleidingsniveau & \multicolumn{5}{c}{ Percentage van de tekorten dat weggewerkt kan worden door scenario: } \\
& I & II & III & IV & V \\
& $\geq 24$ & $+4 \mathrm{kl}$ & $+4 \mathrm{gr}$ & $\mathrm{v}=\mathrm{m}$ & + gew \\
\hline VMB0 & 83 & 35 & 18 & $100+$ & 10 \\
MBO & 83 & 39 & 32 & $100+$ & 17 \\
HB0 & 48 & 23 & 28 & $100+$ & 15 \\
W0 & 13 & 5 & 15 & 41 & 8
\end{tabular}

Scenario I, dat gebaseerd is op het voorstel van de Taskforce deeltijdplus ${ }^{83}$, houdt in dat iedereen minimaal 24 uur gaat werken $(\geq 24)$. Dit scenario zorgt voor een duidelijke afname van het personeelstekort, vooral onder de lagere en middelbare opleidingen. Het tekort aan HBO'ers neemt met bijna de helft af. Voor de WO'ers leidt dit scenario echter slechts tot een afname van de tekorten met ongeveer $13 \%$.

Scenario II - het vergroten van de werkweek met vier uur van werkenden met een kleine deeltijdbaan $(+4 \mathrm{kl})$ - heeft veel minder effect. Het tekort aan VMBO'ers en MBO'ers neemt met respectievelijk $35 \%$ en $39 \%$ af. Dit is een veel geringere afname dan in scenario I, maar nog steeds substantieel. Het opplussen van de kleine deeltijdbanen in dit scenario vermindert ook de tekorten aan HBO'ers en WO'ers met respectievelijk $23 \%$ en $5 \%$ verminderen.

In scenario III leidt de toename van de werkweek van vier uur per week onder werkenden met een grote deeltijdbaan $(+4 \mathrm{gr})$ tot een iets kleinere afname dan bij scenario II wat betreft de tekorten op VMBO- en MBO-niveau. Daarentegen neemt het tekort aan HBO'ers en WO'ers in dit scenario sterker af ten opzichte van scenario II. Voor het terugdringen van het personeelstekort aan HBO'ers en WO'ers geldt dat het opplussen van de werkweek van werkenden met een grote deeltijdbaan een groter effect heeft op het personeelstekort dan het verhogen van de werkweek onder

83. Gebaseerd op de door de taskforce georganiseerde conferentie 24orMore? 
werkenden met een kleine deeltijdbaan. Dit komt doordat onder de hoger opgeleiden een grote deeltijdbaan vaker voorkomt dan onder de laag-en middelbaar opgeleiden.

Scenario IV heeft als uitgangspunt dat vrouwen gemiddeld evenveel uren per week gaan werken als mannen van hetzelfde opleidingsniveau $(\mathrm{v}=\mathrm{m})$. In dit scenario lost het tekort aan VMBO'ers, MBO'ers en HBO'ers volledig op. Op de arbeidsmarkt voor WO'ers is er in dit scenario echter nog steeds een aanzienlijk personeelstekort.

In scenario $\mathrm{V}$ wordt de wens om meer uren te werken van personen met een deeltijdbaan gerealiseerd (+ gew). ${ }^{84}$ Voor deze analyse is gebruik gemaakt van het OSA Arbeidsaanbodpanel 2008. Hieruit blijkt dat $15 \%$ van de werkenden met een kleine deeltijdbaan meer uren willen werken. Gemiddeld willen zij IO,I uur per week meer werken. Van degenen met een grote deeltijdbaan wil 8\% meer uren werken. Het gaat daarbij om gemiddeld 7,8 uur per week. Dit scenario zorgt slechts voor een kleine afname van de tekorten. Op VMBO-niveau zouden de tekorten met IO\% afnemen, op MBO- en HBO-niveau met ongeveer $15 \%$, en op WO-niveau met 7\%. De tekorten nemen dus wel af, maar het zet niet veel zoden aan de dijk in dit scenario. Daarbij dient opgemerkt te worden dat de vraag naar de gewenste arbeidsduur is gesteld in de context van de huidige situatie. ${ }^{85}$ Het wegnemen van belemmeringen om meer te gaan werken, zoals de capaciteit of de kosten van kinderopvang, kunnen dus tot een hogere gewenste arbeidsduur leiden.

Tot nu toe is het effect van het opplussen van deeltijdbanen op de tekorten op de verschillende opleidingsniveaus in kaart gebracht. Het is de vraag bij welke onderliggende opleidingstypen het effect van het opplussen van deeltijdbanen het grootst is. Tabel 4.6 geeft de opleidingstypen weer met de grootste tekorten in de personeelsvoorziening voor werkgevers tot 20I6. Hiervoor zijn de opleidingstypen geselecteerd waarvoor de Indicator Toekomstige Knelpunten in de Personeelsvoorziening (ITKP) kleiner is dan 0,9 . In de tabel wordt aangegeven wat de gemiddelde werkweek is van de werkenden met deze opleidingstypen.

Zo geeft tabel 4.6 aan dat er zeer grote tekorten verwacht worden aan VMBO'ers met een bouw- of metaalopleiding. Ook worden er zeer grote tekorten verwacht aan VMBO'ers met een opleiding (uiterlijke) verzorging. Omdat bij VMBO bouw en VMBO metaal de gemiddelde werkweek al hoog is (beide 39 uur per week), zal het opplussen van deeltijdfuncties bij deze opleidingen niet veel uithalen. Dit is anders voor de VMBO'ers met een opleiding (uiterlijke) verzorging. De gemiddelde werkweek van deze werkenden 22 uur. Het opplussen van de werkweek van degenen met deze opleiding zal de personeelstekorten op dit segment van de arbeidsmarkt wel degelijk kunnen terugdringen.

84. Overigens zijn er ook mensen die liever minder uren zouden willen werken. Hiermee is in dit scenario geen rekening gehouden.

85. Bij de beantwoording van de vraag moeten mensen ervan uitgaan dat hun uurloon gelijk blijft en dat anderen binnen het huishouden niet meer of minder gaan werken. 


\section{Tabel 4.6}

Gemiddelde werkweek van de opleidingstypen met de grootste verwachte personeelstekorten op de middellange termijn, 2009-2010

\begin{tabular}{|c|c|}
\hline Opleidingstypen & $\begin{array}{l}\text { Gemiddelde werkweek } \\
\text { in uren }\end{array}$ \\
\hline \multicolumn{2}{|l|}{ VMBO } \\
\hline VMBO bouw & 39 \\
\hline VMBO metaal & 39 \\
\hline VMBO (uiterlijke) verzorging & 22 \\
\hline \multicolumn{2}{|l|}{ MBO } \\
\hline MBO werktuigbouw en mechanische techniek & 39 \\
\hline MB0 fijnmechanische techniek & 37 \\
\hline MB0 apothekersassistent & 25 \\
\hline MBO verpleging & 25 \\
\hline \multicolumn{2}{|l|}{ HBO } \\
\hline HBO lerarenopleiding basisonderwijs & 29 \\
\hline HBO lerarenopleiding talen & 31 \\
\hline HBO lerarenopleiding natuur en techniek & 36 \\
\hline HBO lerarenopleiding medisch en verzorging & 28 \\
\hline HBO tolk en vertaler & 28 \\
\hline HBO laboratorium & 32 \\
\hline HBO civiele techniek & 39 \\
\hline HBO werktuigbouwkunde & 40 \\
\hline HBO elektrotechniek & 38 \\
\hline HBO chemische technologie & 38 \\
\hline HBO vervoer en logistiek & 38 \\
\hline HBO verpleegkunde & 29 \\
\hline
\end{tabular}

\begin{tabular}{|l|l|}
\hline W0 theologie & 37 \\
\hline W0 bouwkunde & 37 \\
\hline W0 civiele techniek & 38 \\
\hline W0 werktuigbouwkunde & 39 \\
\hline W0 (dier)geneeskunde & 40 \\
\hline W0 tandheelkunde & 39 \\
\hline Bron: CBS/ROA & \\
\hline
\end{tabular}

Op MBO-niveau zijn er tekorten voor $\mathrm{MBO}$ werktuigbouw en mechanische techniek en $\mathrm{MBO}$ verzorging. Twee andere opleidingstypen die in tabel 4.6 voorkomen zijn 
MBO apothekersassistent en $\mathrm{MBO}$ fijnmechanische techniek. Het is opvallend dat de $\mathrm{VMBO}$ - en $\mathrm{MBO}$-opleidingen alleen voorkomen in de richtingen techniek en zorg. Terwijl er weinig ruimte lijkt te zijn voor het opplussen van de werkweek bij degenen met een technische opleidingsachtergrond, lijkt dit wel te kunnen voor werkenden met een zorgopleiding op MBO-niveau. Ook HBO- en WO-opleidingstypen met grote tekorten komen vooral voor in de richtingen techniek, zorg en onderwijs. Omdat de gemiddelde werkweek voor de WO-opleidingen met grote verwachte tekorten tegen de 40 uur ligt, zal het opplussen van deeltijdbanen een klein effect hebben op de omvang van deze tekorten.

In tabel 4.7 wordt per opleidingstype bekeken hoeveel procent van de tekorten weggewerkt kan worden door het invoeren van de verschillende opplusscenario's. Zoals verwacht kan het opplussen van het aantal arbeidsuren van deeltijders niet leiden tot een significante vermindering van het personeelstekort voor VMBO bouw en VMBO metaal. Het hoogst haalbare voor deze opleidingstypen is een vermindering van het personeelstekort met ongeveer IO\%. In dat geval zou iedereen minimaal 24 uur per week moeten werken. Ook het grote tekort aan personeel met een technische opleiding op MBO-, HBO- en WO-niveau is moeilijk weg te werken door het opplussen van deeltijdbanen. De verwachte tekorten aan arbeidskrachten worden bij deze opleidingen voor minder dan $30 \%$ opgelost.

De opplusscenario's kunnen daarentegen wel degelijk helpen bij het verminderen van de tekorten in de zorg. Met name de maatregelen in scenario's I en IV zouden effectief kunnen zijn. Scenario I, waarin iedereen met een kleine deeltijdbaan 24 uur per week gaat werken, zou het tekort aan personeel met een opleiding VMBO (uiterlijke) verzorging ruimschoots oplossen. Dat geldt ook voor scenario IV, waarin verondersteld wordt dat vrouwen evenveel gaan werken als de mannen met dezelfde opleidingsachtergrond. Ook in dit scenario zouden de personeelstekorten voor $\mathrm{MBO}$ en $\mathrm{HBO}$ verpleging en $\mathrm{MBO}$ apothekersassistent ruimschoots worden weggewerkt. De scenario's waarin werkenden met een kleine deeltijdbaan (scenario II) of een grote deeltijdbaan (scenario III) gemiddeld 4 uur per week meer gaan werken zorgt bij $\mathrm{VMBO}$ (uiterlijke) verzorging, $\mathrm{MBO}$ verpleging en $\mathrm{MBO}$ apothekersassistent ook voor een behoorlijke afname in de verwachte tekorten. Het laatste scenario waarin wordt uitgegaan van het opplussen van de deeltijdbanen van degenen die meer uren willen werken, leidt bij een aantal zorgopleidingen (behalve op WO niveau) tot een afname van de verwachte tekorten met circa 20\%. Zorginstellingen kunnen hun personeelstekorten aan $\mathrm{MBO}$ verpleegkundigen met een vijfde terugdringen als zij tegemoet kunnen komen aan de wensen van hun personeel om hun functieomvang te vergroten. Een uitzondering hierop is het tekort aan personeel van $\mathrm{MBO}$ verpleging. Scenario V leidt nauwelijks tot een vermindering van het tekort. De tekorten aan personeel met een medische opleiding op WO-niveau zijn nauwelijks terug te dringen door de vijf hier beschreven scenario's. Een afname in de tekorten van meer dan $40 \%$ kan hier alleen gerealiseerd worden wanneer vrouwen evenveel gaan werken als mannen. 
Tabel 4.7

Gevolgen van opplusscenario's voor de opleidingstypen met de grootste verwachte personeelstekorten, 2011-2016

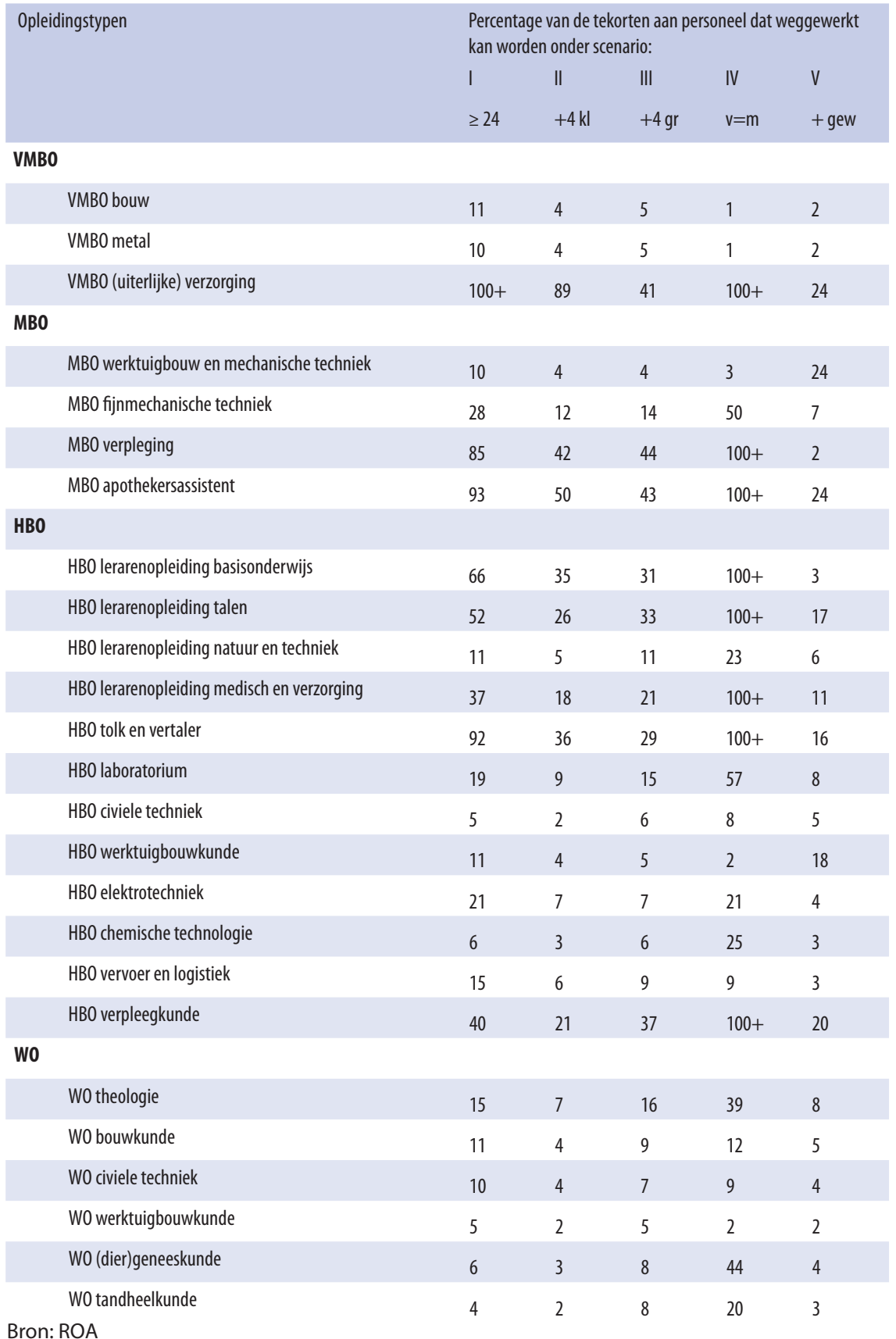


Met uitzondering van de $\mathrm{HBO}$ lerarenopleiding natuur en techniek, is het tekort aan personeel voor de $\mathrm{HBO}$ lerarenopleidingen goed terug te dringen door het opplussen van deeltijdbanen. Het tekort aan personeel met een HBO lerarenopleiding basisonderwijs kan voor meer dan twee derde worden opgelost als iedereen met een dergelijke opleiding minimaal 24 uur per week gaat werken. Maar ook het verhogen van de werkweek van werkenden met een kleine of grote deeltijdbaan leidt tot een afname van het tekort met minimaal $30 \%$. Het minst doeltreffend is het scenario waarin iedereen die meer zou willen gaan werken dit ook daadwerkelijk gaat doen.

Met name voor de opleidingstypen waarin de gemiddelde werkweek dicht tegen de 40 uur aan zit, ligt het voor de hand dat het opplussen van deeltijdbanen niet erg doeltreffend is voor het verminderen van de te verwachte tekorten. Om dit goed in beeld te brengen is voor alle opleidingstypen uit tabel 4.7 berekend wat de gemiddelde werkweek zou moeten zijn om de tekorten voor het desbetreffende opleidingstype geheel te laten verdwijnen. In figuur 4.4 zijn de resultaten weergegeven.

Voor bijna alle opleidingstypen zou de gemiddelde werkweek boven de voltijdse arbeidsduur van 40 uur per week moeten liggen om de verwachte personeelstekorten in hun geheel te laten verdwijnen. Voor een achttal opleidingstypen blijft de gemiddelde werkweek die nodig is om de tekorten op te lossen onder de 40 uur. Daarbij gaat het om VMBO (uiterlijke) verzorging, $\mathrm{MBO}$ verpleging, $\mathrm{MBO}$ apothekersassistent, $\mathrm{HBO}$ lerarenopleiding medisch en verzorging, $\mathrm{HBO}$ verpleging, $\mathrm{HBO}$ tolk en vertaler, $\mathrm{HBO}$ lerarenopleiding basisonderwijs en $\mathrm{HBO}$ lerarenopleiding talen. Het betreft bijna allemaal zorgopleidingen. Verder is het opvallend dat op WO-niveau alle opleidingstypen uitkomen op een gemiddelde werkweek van meer dan 40 uur om de personeelstekorten volledig weg te werken.

Zoals te verwachten op basis van tabel 4.7 is er een grote toename in de gemiddelde werkweek nodig voor de VMBO opleidingen bouw en metaal. Om de verwachte tekorten voor $\mathrm{VMBO}$ bouw op te lossen is een toename in de gemiddelde werkweek van 8 uur nodig, wat een volledige werkdag is. Omdat de gemiddelde werkweek in 2009-2010 al 39 uur per week is, zou voor de werkenden met deze opleidingsachtergrond structureel overgewerkt moeten worden om de personeelstekorten te verhelpen. Een toename van minimaal 8 uur per week is ook vereist als de personeelstekorten verholpen moeten worden voor een achttal andere opleidingstypen. HBO lerarenopleiding medisch en verzorging, $\mathrm{HBO}$ laboratorium, $\mathrm{HBO}$ lerarenopleiding natuur en techniek hebben een toename in de gemiddelde werkweek van 9 uur nodig om het tekort op te lossen. Voor WO chemische technologie en WO werktuigbouwkunde is eveneens een toename in de gemiddelde werkweek van 9 uur nodig om de tekorten te laten verdwijnen. Voor WO bouwkunde is een toename in de gemiddelde werkweek van 8 uur nodig. Voor andere WO opleidingen gericht op de gezondheidszorg is een toename van een werkdag per week nog lang niet genoeg. Bij WO (dier)geneeskunde is een toename in de gemiddelde werkweek van I2 uur benodigd. Voor WO tandheelkunde is zelfs een toename van 2I uur per week nodig voordat de verwachte tekorten 
weggewerkt zijn. Deze cijfers geven aan dat het vergroten van de gemiddelde werkweek niet de enige oplossing kan zijn om de personeelstekorten op de middellange termijn weg te werken.

\section{Figuur 4.4}

Benodigde toename in de gemiddelde werkweek om de personeelstekorten in 2016 weg te werken voor de opleidingstypen met de grootste tekorten in de personeelsvoorziening

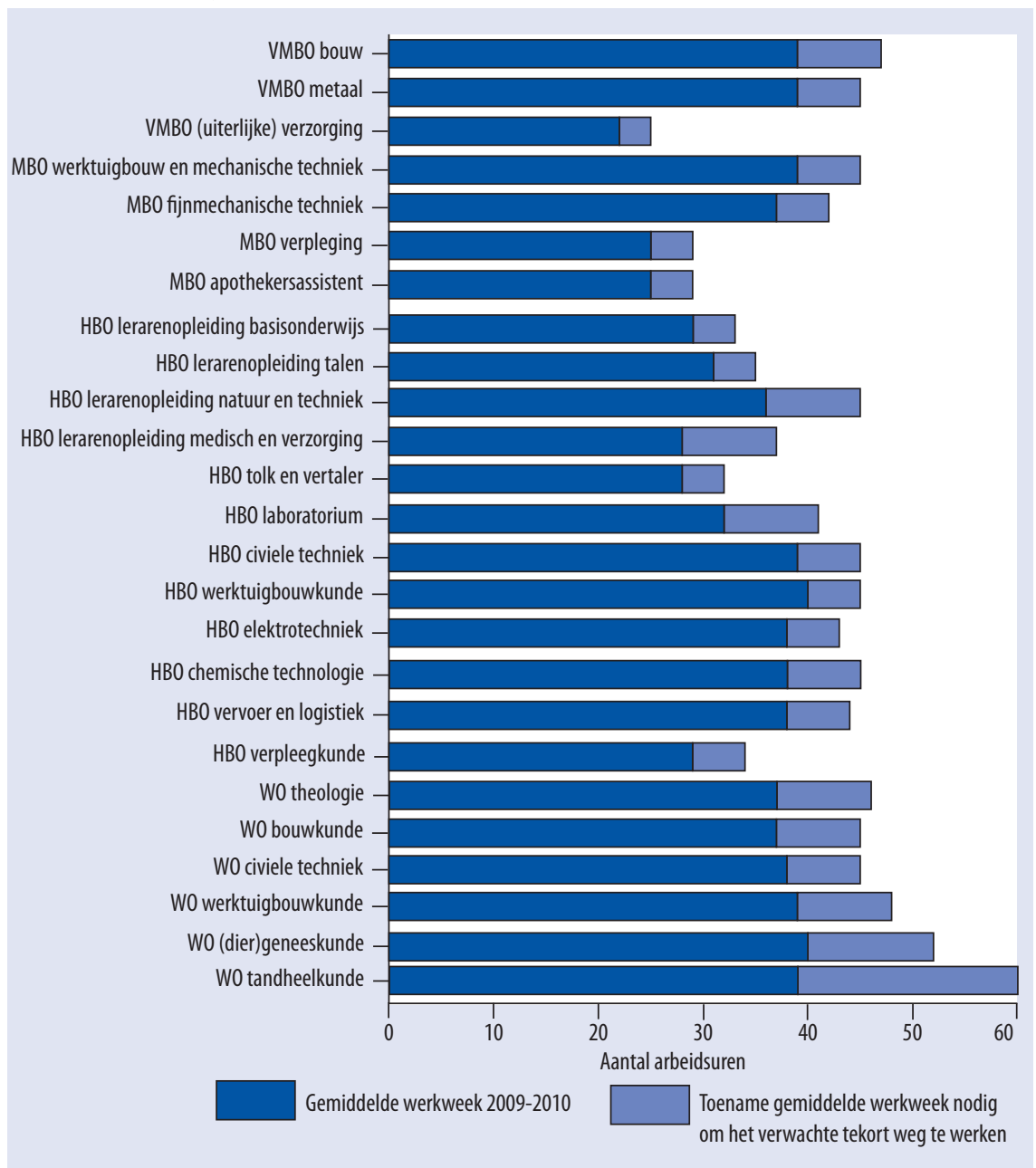

Bron: ROA 


\subsection{Conclusies}

In Nederland wordt er in vergelijking met andere landen veel in deeltijd gewerkt. Met name vrouwen maken in grote mate gebruik van de mogelijkheid om in deeltijd werken. Twee wetten hebben de toename van het aantal deeltijdbanen versterkt. De Wet gelijke behandeling heeft er voor gezorgd dat de kwaliteit van deeltijdbanen niet of nauwelijks onderdoet voor voltijdse banen in dezelfde functies. Daarnaast heeft de Wet aanpassing arbeidsduur er voor gezorgd dat deeltijdbanen in vrijwel alle sectoren voorkomen. Tegenwoordig wordt er echter regelmatig gesproken over de mogelijke risico's die het grote aantal deeltijders macro-economisch gezien met zich meebrengt. Het gaat dan met name om de handhaving van ons welvaartniveau. Als de arbeidsmarktparticipatie in termen van het gewerkte aantal uren niet toeneemt kunnen bijvoorbeeld toekomstige pensioenbetalingen in het geding komen, en kan het tekort aan docenten dusdanig toenemen dat de kwaliteit van het onderwijs er onder lijdt. Bovendien kunnen de wachtlijsten in de zorg groeien door het gebrek aan arbeidsaanbod. Hoewel het arbeidsaanbod ook kan toenemen door het verhogen van de arbeidsparticipatie wordt vaak gedacht dat het opplussen van deeltijdbanen in Nederland meer soelaas biedt.

Dit hoofdstuk laat zien dat in de meeste bedrijfssectoren de gemiddelde werkweek de afgelopen decennia gestaag is gedaald. Er blijkt geen eenduidige relatie te zijn tussen de omvang van de gemiddelde werkweek en het opleidingsniveau van werkenden. Zo werken de hoger opgeleiden met een zorgopleiding of economische opleiding beduidend meer uren per week dan de laagopgeleiden in deze opleidingssectoren, terwijl bij de (bèta)technische opleidingen juist de lager opgeleiden gemiddeld meer uren per week werken. Ook blijken er in Nederland veel deeltijders minder dan 24 uur per week te werken. Deze kleine deeltijdbanen doen zich vooral voor bij opleidingstypen met veel vrouwen. De opleidingen met het hoogste deeltijdpercentage zijn bijna allemaal zorgopleidingen op laag- en middelbaar niveau.

Deeltijders volgen - ondanks de Wet gelijke behandeling - toch minder werkgerelateerde cursussen. Door hun kortere werkweek besteden ze ook minder tijd aan taken waarvan zij kunnen leren. Analyses naar de oorzaak van het verschil in trainingsparticipatie geven aan dat dit grotendeels te wijten is aan een gebrek aan stimulans van werkgevers voor het verder ontwikkelen van het menselijk kapitaal van deeltijders. Deeltijders kunnen dit gebrek aan stimulans van hun werkgever slechts gedeeltelijk compenseren indien zij een goed beeld hebben van hun verdere loopbaan en erg gemotiveerd zijn om te leren.

Bedrijven kunnen voordeel hebben bij het aanstellen van deeltijders. Uit onderzoek in de apotheekbranche komt naar voren dat apotheken die relatief meer deeltijders in dienst hebben een hogere arbeidsproductiviteit kennen. De inzet van deeltijders creëert namelijk de mogelijkheid om personeel zeer efficiënt in te zetten. De voordelen van het gebruik van deeltijders zullen afhangen van de mate waarin er voordelen te 
halen zijn uit een efficiënte allocatie van het personeel. Deze voordelen zullen wellicht het grootst zijn in de detailhandel, de zorgsector en de horeca waar de openingstijden langer zijn dan de voltijdse werkweek en waar gedurende de werkdag of -week schommelingen zijn in de vraag naar personeel.

Voor de technische opleidingen waarvoor grote personeelstekorten worden verwacht blijkt het opplussen van deeltijdbanen weinig zoden aan de dijk te zetten. Daarentegen blijkt het tekort aan mensen met een zorgopleiding wel degelijk terug te dringen als de deeltijdbanen in de zorgsector opgeplust worden. Wanneer alle werkenden met een $\mathrm{MBO}$ zorgopleiding minimaal 24 uur gaan werken, zouden de personeelstekorten bij deze opleidingen voor minstens $85 \%$ verdwijnen. Het tekort aan mensen met een opleiding $\mathrm{HBO}$ verpleging zou in dit scenario echter slechts met $40 \%$ afnemen. Het scenario waarin vrouwen evenveel werken als mannen met dezelfde opleidingsachtergrond zou alle tekorten aan personeel met een VMBO-, MBO- of HBO-zorgopleiding doen verdwijnen. Voor de medische opleidingen op WO-niveau blijkt het opplussen van deeltijdbanen daarentegen weinig te helpen. De voornaamste reden hiervoor is dat de gemiddelde werkweek onder degenen met deze opleidingsachtergrond (bijvoorbeeld tandheelkunde of geneeskunde) al tegen de 40 uur ligt.

Een scenario waarin iedereen die meer wil werken de gewenste arbeidsduur zou kunnen realiseren, leidt over het algemeen tot een kleine afname van de verwachte tekorten. Een afname van de personeelstekorten met $24 \%$ blijkt het maximaal mogelijke. De tekorten aan personeel met een opleiding $\mathrm{MBO}$ verpleging nemen in dit scenario echter slechts met $2 \%$ af. Hoewel het opplussen van deeltijdwerk de verwachte tekorten in meer of mindere mate kan terugdringen, kunnen er ook negatieve gevolgen zijn voor de gemiddelde arbeidsproductiviteit. Dit kan komen doordat in de bedrijven waar veel in deeltijd gewerkt wordt, de arbeidsproductiviteit hoger is dan in andere bedrijven.

Op basis van de resultaten van dit onderzoek kunnen twee aanbevelingen worden gedaan voor het personeelsbeleid van organisaties waar veel deeltijders werkzaam zijn. In de eerste plaats zullen werkgevers de ontwikkeling van het menselijk kapitaal van deeltijders evenveel moeten stimuleren als dat ze dat bij voltijders doen. Ook al is het vanuit werkgeversperspectief voordeliger om voltijders in plaats van deeltijders te trainen, het kennisniveau van de deeltijders is belangrijk voor de bedrijfsproductiviteit en de internationale concurrentiepositie van Nederland. Maar deeltijders dienen ook meer gestimuleerd te worden om te investeren in hun kennis en vaardigheden. Omdat hun trainingsparticipatie vooral beïnvloed wordt door hun leermotivatie en het beeld dat zij hebben van hun verdere loopbaan, is het nodig dat zij meer informatie krijgen over het belang van het ontwikkelen van hun kennis en vaardigheden voor hun arbeidsmarktpositie.

In de tweede plaats zullen werkgevers meer aandacht moeten besteden aan het opplussen van deeltijdbanen. Op verschillende segmenten van de arbeidsmarkt kan 
dit de komende jaren een belangrijke bijdrage leveren aan het terugdringen van te verwachten tekorten op de arbeidsmarkt. Dit opplussen van deeltijdbanen zal in overleg met de werknemer moeten plaatsvinden. Mensen verplichten om meer te gaan werken zal het personeelsverloop juist kunnen vergroten en ook negatieve consequenties kunnen hebben voor de baantevredenheid, het ziekteverzuim en de productiviteit. Uit het rapport Deeltijd (g)een probleem? van het Sociaal en Cultureel Planbureau blijkt dat veel vrouwen bereid zijn meer te gaan werken, mits aan een aantal voorwaarden wordt voldaan. Veelgenoemde voorwaarden zijn een goede afstemming van de werktijden op de privésituatie $(33 \%)$, een werkgever die het hen vraagt $(33 \%)$ en de mogelijkheid om meer thuis te werken (25\%). ${ }^{86}$ Terwijl onder de huidige condities slechts IO\% van de vrouwen graag meer zou willen werken, wil maar liefst $60 \%$ van de vrouwen meer werken als aan dergelijke voorwaarden wordt voldaan. ${ }^{87}$

In de derde plaats laten de resultaten van de opplusscenario's zien dat er geen sprake is van een 'one size fits all' oplossing is om de arbeidsaanbodproblemen op te lossen. Per sector zijn er duidelijke verschillen waarop de sociale partners zouden kunnen inspelen. Helaas ontbreekt het momenteel aan goede informatie die het mogelijk makkt om het effect van specifieke HR-instrumenten of overheidsmaatregelen op de verwachte krapte op de arbeidsmarkt te onderzoeken. Hiervoor is onderzoek nodig dat nagaat in hoeverre de arbeidsduur van vrouwen die in deeltijd werken verandert als gevolg van specifieke maatregelen. Daarbij kan gedacht worden aan het effect van bijvoorbeeld een verruiming van de openingsuren van kinderopvang, of het vergroten van de mogelijkheden om gedeeltelijk thuis te werken, maar ook aan het HR-beleid met betrekking tot de mogelijke werktijden, het thuiswerken e.d. Op deze manier zouden de effecten van een meer gespecificeerd opplusscenario op de verwachte personeelstekorten berekend kunnen worden.

86. S. Keuzenkamp, C. Hillebrink, W. Portegijs en B. Pouwels (2009), Deeltijd (g)een probleem? Mogelijkheden om de arbeidsduur van vrouwen met een kleine deeltijdbaan te vergroten, SCP 2009/I5, Den Haag.

87. Het betreft een enquête onder vrouwen met een kleine deeltijdbaan binnen 'vrouwensectoren' (overheid, zorg en welzijn, onderwijs, detailhandel en schoonmaak). 



\section{De rol van economische voorkeuren bij de beroepskeuze van schoolverlaters}

\section{$5.1 \quad$ Inleiding}

De keuze van een beroep is een belangrijke beslissing in het leven van een jongvolwassene. Het markeert de overgang van school naar werk, het begin van een nieuwe, belangrijke fase in de levenscyclus. Het kiezen van het 'juiste' beroep is niet alleen belangrijk vanuit het perspectief van een individu. De optimale allocatie van individuen naar beroepen is ook van belang in het kader van een doelmatig allocatie van arbeid. Een optimale initiële keuze voorkomt kostbare herallocatie later in de loopbaan. Herallocatie als gevolg van verkeerde keuzes is duur voor het individu, de werkgever en de samenleving, omdat het gepaard gaat met verlies van beroepsspecifiek menselijk kapitaal. Bovendien verplicht het werkgevers om op zoek te gaan naar vervanging.

Economen gaan ervan uit dat individuen beroepen kiezen om hun nut te maximaliseren gegeven de beschikbare informatie, beperkingen, prikkels en, belangrijker, op basis van voorkeuren. ${ }^{88}$ De voorspellende waarde van voorkeuren en het bestaan van substantiële verschillen in individuele voorkeuren - zoals risicoattitude en tijdsvoorkeur - zijn goed gedocumenteerd. ${ }^{89}$ Deze voorkeuren hebben naar verwachting invloed op de beroepskeuze. Bijvoorbeeld, personen die risico-avers zijn zullen naar verwachting worden afgeschrikt door beroepen die worden gekenmerkt door een hoog loonrisico of beroepsrisico in de vorm van beroepsongevallen. Ook wordt voor-

88. Hier wordt uitgegaan van een economisch model waarin voorkeuren centraal staan. De twee belangrijkste voorkeuren bij economische beslissingen zijn risico-aversie en tijdsvoorkeur. Alternatieve verklaringsmodellen voor de beroepskeuze waarin sociaal-culturele aspecten centraal staan (bijv. rol van ouderlijk milieu, vrienden en sociale omgeving) vallen buiten het bereik van dit hoofdstuk. De analyses in dit hoofdstuk zouden uitgebreid kunnen worden en geplaatst binnen het kader van een breder model voor studie- en beroepskeuze.

89. T. Dohmen, A. Falk, D. Huffman, U. Sunde, J. Schupp en G. Wagner (20II), 'Individual risk attitudes: measurement, determinants and behavioral consequences', Journal of the European Economic Association, Vol. 9, pp. 522-550. 
speld dat individuen met een zwakke tijdsvoorkeur - mensen die geduldig zijn sterker worden aangetrokken door beroepen met steile loonprofielen en uitgestelde beloningen.

Er is weinig onderzoek gedaan naar de empirische relatie tussen risicoattitude, tijdsvoorkeur en de beroepskeuze. In dit hoofdstuk wordt voortgebouwd op de analyses in paragraaf 3.4 van hoofdstuk 3 door te kijken of schoolverlaters voor kenmerken van beroepen kiezen in overeenstemming met hun voorkeuren. Wanneer dit het geval is, dan is het verschaffen van informatie over beroepskenmerken van grote waarde om scholieren en studenten te helpen bij hun beroepskeuze. Gebruikmakend van een grootschalig onderzoek onder schoolverlaters in Nederland wordt de risicoattitude en de tijdsvoorkeur van jongeren gemeten kort nadat zij op de arbeidsmarkt zijn ingestroomd. Aan de hand van grootschalige enquêtes en administratieve data worden beroepen gekarakteriseerd door een vijftal indicatoren met betrekking tot het loonrisico, het werkgelegenheidsrisico en de loongroei:

- loonrisico: de spreiding van het loon in de beroepsbevolking, en de spreiding van het loon bij een leeftijd van 40-49 jaar;

- werkgelegenheidsrisico: de conjunctuurgevoeligheid en de kans om werkloos te worden;

- loongroei: gemiddelde loongroei in een beroep tussen de leeftijdsgroepen 20-29 jaar en 40-49 jaar.

In paragraaf 5.2 wordt aangegeven wat de relatie is tussen de hier gepresenteerde analyses en eerder onderzoek op dit terrein. Paragraaf 5.3 bevat een beschrijving van de gebruikte data en de belangrijkste begrippen. De resultaten van de beschrijvende en econometrische analyses worden besproken in respectievelijk paragraaf 5.4 en paragraaf 5.5. Na een discussie van de robuustheid van deze bevindingen in paragraaf 5.5, komt in paragraaf 5.6 de relatie tussen mismatch en beroepsmobiliteit aan bod. De conclusies worden in paragraaf 5.7 weergegeven.

\subsection{Relatie tot eerder onderzoek}

\section{Risicoattitude}

Eén van de weinige studies die ingaat op de relatie tussen risicoattitude en beroepskeuze is die van Bonin e.a. (2007)..$^{\circ}$ De auteurs rapporteren voor Duitsland een positieve correlatie tussen de standaarddeviatie van lonen in beroepen en de risicoattitude van volwassenen die werkzaam zijn in de betreffende beroepen. DeLeire en Levy (2004) laten zien dat mensen die minder bereid zijn om risico's te nemen vaker voor veiligere beroepen kiezen, dat wil zeggen beroepen waar de kans op een dodelijk

90. H. Bonin, T. Dohmen, A. Falk, D. Huffman en U. Sunde (2007), 'Cross-sectional earnings risk and occupational sorting: The role of risk attitudes', Labour Economics, Vol. I4, pp. 926-937. 
bedrijfsongeval klein is. ${ }^{91}$ Weer andere studies rapporteren een positief verband tussen risicovoorkeuren en zelfstandig ondernemerschap.

\section{Tijdsvoorkeur}

Studies door Antecol en Cobb-Clark (20I0) en Munasinghe en Sicherman (2006) geven aanwijzingen dat tijdsvoorkeur een belangrijke determinant is van de beroepskeuze. ${ }^{92}$ Antecol en Cobb-Clark (20IO) karakteriseren beroepen aan de hand van het aandeel mannen en het gemiddeld loon in de betreffende beroepen. Zij laten zien dat de bereidheid om hard te werken, impulsiviteit en de neiging om problemen te voorkomen positief correleren met de keuze om te werken in mannenberoepen. Hun maatstaf voor impulsiviteit is gerelateerd aan economische voorkeuren, maar makkt het niet mogelijk om risicoattitude en tijdsvoorkeur van elkaar te scheiden. Dit omdat deze maatstaf geconstrueerd wordt op basis van items zoals onderbuikgevoel, de neiging om risico's te nemen en de voorkeur voor de korte termijn. Munasinghe en Sicherman (2006) gebruiken het rookgedrag als een benadering voor tijdsvoorkeur (rokers hebben een hoge discontovoet, dat wil zeggen dat zij gemiddeld genomen de toekomst onderwaarderen) en laten zien dat rokers vlakkere beloningsprofielen hebben dan niet-rokers.

\section{Beroepskeuze van schoolverlaters}

Bovenstaande studies kunnen echter geen causale relatie leggen tussen risico- en tijdsvoorkeur enerzijds en de beroepskeuze anderzijds. Dit komt doordat werkenden in die studies al langere tijd zijn blootgesteld aan de kenmerken van hun beroep waardoor onduidelijk is of zij het betreffende beroep hebben gekozen op basis van hun voorkeuren of dat zij hun voorkeuren hebben aangepast aan de kenmerken van hun beroep.

Het uitgangspunt in dit hoofdstuk is de analyse door Bonin e.a. (2007), maar de hier gevolgde aanpak verschilt op een aantal belangrijke punten. In de eerste plaats zijn de analyses gebaseerd op schoolverlaters die pas relatief kort op de arbeidsmarkt actief zijn. Het is niet aannemelijk dat hun korte ervaring op de arbeidsmarkt hun voorkeuren heeft beïnvloed of dat hun ervaring ze heeft beperkt in het soort beroep waarin zij inzetbaar zijn. Het is dan ook onwaarschijnlijk dat de hier waargenomen correlaties tussen voorkeuren en beroepskenmerken endogeen bepaald zijn door langdurige blootlegging aan bepaalde karakteristieken van beroepen op de arbeidsmarkt. In de tweede plaats, en in tegenstelling tot eerder onderzoek, zijn de kenmerken van

9I. T. DeLeire en H. Levy (2004), 'Worker sorting and the risk of death on the job', Journal of Labor Economics, Vol. 22, pp. 925-953.

92. H. Antecol en D.A. Cobb-Clark (2010), Do non-cognitive skills help explain do non-cognitive skills help explain the occupational segregation of young people?, IZA DP 5093, Bonn; L. Munasinghe en N. Sicherman (2006), 'Why do dancers smoke? Smoking, time preference, and wage dynamics', Eastern Economic Journal, Vol. 32, pp. 595-616. 
beroepen afkomstig uit andere grootschalige databronnen dan de data waarin de voorkeuren gemeten zijn. Hierdoor is het simultaniteitsprobleem tussen voorkeuren van schoolverlaters en de kenmerken van hun baan verwaarloosbaar. In de derde plaats wordt in dit hoofdstuk niet alleen gekeken naar het loonrisico, maar ook naar het werkgelegenheidsrisico en de loongroei binnen beroepen.

\subsection{Data en begrippen}

\section{Voorkeuren en beroep schoolverlaters}

De economische voorkeuren van schoolverlaters en hun beroep worden gemeten in een speciale module van de ROA Schoolverlatersenquête. Schoolverlaters zijn personen die zich uitschrijven uit een opleiding, in de meeste gevallen na het behalen van een diploma. Een representatieve steekproef daarvan wordt ca. I,5 jaar na het verlaten van de opleiding benaderd ten behoeve van de enquête. In het najaar van 2008 hebben ongeveer 39.000 schoolverlaters van alle opleidingsniveaus en -richtingen aan de enquête deelgenomen. Op het moment van enquêtering heeft ongeveer $40 \%$ van de schoolverlaters de arbeidsmarkt betreden terwijl ongeveer $60 \%$ door is gegaan met een vervolgopleiding. ${ }^{33}$ Van de werkende schoolverlaters is het beroep gecodeerd in de 43 beroepssegmenten van het CBS (2-digit Standaard Beroepenclassificatie).

De speciale vragenmodule die in dit themahoofdstuk wordt gebruikt bouwt voort op deze enquête. Deze is via het internet afgenomen bij de respondenten die in de ROA Schoolverlatersenquête van 2008 aangaven bereid te zijn om deel te nemen aan een vervolgonderzoek. ${ }^{94}$ De vervolgenquête is in het najaar van 2009 afgenomen en bevatte vragen over economische voorkeuren en persoonlijkheid. Ongeveer 8.700 schoolverlaters hebben deelgenomen aan deze speciale module, 95 van wie voor dit hoofdstuk alleen gegevens gebruikt worden van werkende schoolverlaters die niet ouder zijn dan 35 jaar. In totaal gaat het om 4.575 personen. Hun leeftijd is afhankelijk van het gevolgde opleidingstraject. Gemiddeld genomen zijn ze 23 jaar oud.

De algemene risicoattitude is gemeten aan de hand van een gevalideerde enquêtevraag waarin respondenten wordt gevraagd in welke mate zij bereid zijn om risico's te nemen. Zij kunnen antwoorden op een schaal van o ('helemaal niet bereid om risico's

93. Het percentage dat doorleert verschilt sterk per opleidingsniveau en is hoog onder schoolverlaters uit het vmbo en havo/vwo (88\%) en laag bij hbo'ers en wo'ers (34\%).

94. Ongeveer 2I.00o deelnemers aan de ROA Schoolverlatersenquête hebben aangegeven bereid te zijn om deel te nemen aan een vervolg enquête en hebben hun e-mailadres opgegeven.

95. De respons varieert naar opleidingsniveau. Het percentage dat daadwerkelijk heeft deelgenomen aan de vervolgenquête is als volgt: vmbo $38 \%$, mbo $43 \%$, havo/vwo $5 \mathrm{I} \%$, hbo $46 \%$, wo $54 \%$. Er zijn geen verschillen in respons naar leeftijd, maar vrouwen en autochtonen hebben wel een grotere respons. In de analyses wordt om die reden gecontroleerd voor achtergrondkenmerken van de respondenten. 
te nemen') tot Io ('zeer bereid om risico's te nemen'). ${ }^{96}$ Er werd ook een specifiekere vraag gesteld om de risicoattitude met betrekking tot de carrière te meten: 'In welke mate ben je bereid om risico's te nemen als het om je carrière gaat?'. Deze vraag staat centraal in dit themahoofdstuk.

Tijdsvoorkeur wordt gemeten aan de hand van twee items op een gevalideerde schaal: ${ }^{97}$ 'Ik denk na over hoe dingen in de toekomst kunnen zijn, en probeer deze in mijn leven van iedere dag te beïnvloeden' en 'Vaak houd ik mij bezig met zaken die pas over enige jaren gevolgen zullen hebben'. Respondenten konden aangeven in welke mate zij het met de twee stellingen eens waren op de schaal van I ('helemaal niet mee eens') tot 7 ('helemaal mee eens'). Geduld, als maatstaf voor tijdsvoorkeur, wordt gemeten als het gemiddelde van de antwoorden op deze twee vragen.

\section{Loonrisico}

In navolging van Bonin e.a. (2007) wordt het beroepsspecifiek loonrisico gemeten als de standaarddeviatie van de residuen uit een Mincer loonschatting. Om het simultaniteitsprobleem tussen voorkeuren en loonrisico uit te sluiten wordt dit geschat op externe data die representatief zijn voor de totale beroepsbevolking. De beloningsfunctie wordt geschat op administratieve loongegevens uit het Sociaal Statistisch Bestand (SSB) waaraan gegeven uit de Enquête Beroepsbevolking (EBB) gekoppeld zijn. Deze koppeling is noodzakelijk omdat het SSB geen gegevens bevat over het opleidingsniveau, de opleidingsrichting en het beroep. De data hebben betrekking op de periode 200I-2007, en bevat $\mathbf{1 7 2 . 0 0 0}$ personen in de leeftijd van 20-59 jaar.

De beloningsfunctie is een regressievergelijking van het uurloon (in log) op geslacht, leeftijd (lineair en kwadratisch), jaar dummies, 27 opleidingsdummies voor niveau en richting van de hoogst genoten opleiding, en 43 beroepsdummies. Een eerste maatstaf voor het beroepsspecifiek loonrisico is dus de standaarddeviatie van de residuen (het onverklaarde deel) uit deze regressievergelijking, uitgerekend per beroep.

Het is echter denkbaar dat schoolverlaters niet zozeer geïnteresseerd in het loonrisico over de gehele leeftijdsverdeling, maar eerder in het loonrisico van een beroep als zij eenmaal een stabiel punt in hun carrière hebben bereikt, bijvoorbeeld bij een leeftijd van 40-49 jaar. Hier wordt dan ook het beroepsspecifiek loonrisico berekend bij een leeftijd van 40-49 jaar door, voor elk beroep, de standaarddeviatie van de residuen te berekening voor deze specifieke leeftijdsgroep.

96. T. Dohmen, A. Falk, D. Huffman, U. Sunde, J. Schupp en G.G. Wagner (20II). 'Individual risk attitudes: measurement, determinants and behavioral consequences', Journal of the European Economic Association, Vol. 9, pp. 522-550.

97. A. Strathman, F. Gleicher, D. Boninger en C. Edwards (1994), 'The consideration of future consequences: Weighing immediate and distant outcomes of behavior', Journal of Personality and Social Psychology, Vol. 66, pp. 742-752. 
Beide maatstaven voor het beroepsspecifiek loonrisico zijn gekoppeld aan de schoolverlaters aan de hand van de beroepscode. De verwachting is dat schoolverlaters met een sterke risicoattitude zich sorteren in beroepen met een hoog loonrisico.

\section{Werkgelegenheidsrisico}

Het werkgelegenheidsrisico van een beroep kan van belang zijn omdat het informatie bevat die niet door het loonrisico wordt overgedragen, zoals bijvoorbeeld de psychologische kosten van het niet kunnen vinden van een baan of om werkloos te worden. Er worden dan ook twee maatstaven gehanteerd voor het beroepsspecifiek werkgelegenheidsrisico: de conjunctuurgevoeligheid en het werkloosheidsrisico. ${ }^{98}$

De conjunctuurgevoeligheid van een beroep geeft een indicatie van de mate waarin het niveau van de werkgelegenheid in een beroep met de conjunctuur meefluctueert. Het geeft dus een indicatie van de baanzekerheid in een bepaald beroep. Deze indicator is afkomstig uit het Arbeidsmarktinformatiesysteem van het ROA en wordt berekend op basis van de fluctuaties in de werkgelegenheid over de jaren 1987-2008.99

Het werkloosheidsrisico is de kans om werkloos te worden, gegeven dat men in een bepaald beroep werkzaam is. Het is berekend op basis van de 1994-2008 peilingen van het Arbeidsaanbodpanel, met II.200 personen (25.000 arbeidsjaren) in de leeftijd 20-59 jaar. Het werkloosheidsrisico is de geschatte kans op werkloosheid (uit een probit model) tussen twee peilingen. Het model controleert voor geslacht, leeftijd, opleiding, jaar en beroep.

Beide indicatoren zijn berekend voor 43 beroepssegmenten en gekoppeld aan de schoolverlatersgegevens op basis van de beroepscode. De verwachting is dat schoolverlaters met een sterke risicoattitude zich sorteren in beroepen met hoge conjunctuurgevoeligheid en een hoog werkloosheidsrisico.

\section{Loongroei}

De loongroei is een maatstaf voor de stijging van het loonprofiel. Het is berekend als het verschil in uurloon voor de leeftijdsgroep 40-49 jaar en 20-29 jaar. De loongroei is berekend voor elk van de 43 beroepssegmenten en gekoppeld aan de schoolverlatersdata aan de hand van de beroepscode. De verwachting is dat schoolverlaters met een sterke mate van geduld zich sorteren in beroepen met een sterke loongroei.

Beschrijvende statistieken voor de hierboven besproken variabelen zijn, per beroepssegment, opgenomen in tabel B5.I van de bijlage bij dit hoofdstuk. De bijlage rapporteert ook over de top vijf van beroepssegmenten naar geselecteerde beroepskenmerken.

98. In een vervolgstudie zou gekeken kunnen worden naar andere, meer structurele indicatoren van beroepsrisico's.

99. F. Cörvers, A. Dupuy, S. Dijksman, B. Kriechel en R. Montizaan (2010), Methodiek arbeidsmarktprognoses en -indicatoren 2009-2014, ROA Technical Report TR-20Io/5, Universiteit Maastricht. 


\subsection{Voorkeuren en beroepskenmerken}

In deze paragraaf wordt de relatie beschreven tussen de economische voorkeuren van schoolverlaters (risicoattitude en geduld) en de kenmerken van het beroep waarin zij werkzaam zijn. Dit gebeurt aan de hand van grafieken waarin de gemiddelde voorkeur op de $\mathrm{x}$-as wordt weergegeven en het betreffende kenmerk van het beroep op de $y$-as. De beroepen worden weergegeven door cirkels waarbij de grootte van de cirkel correspondeert met de grootte van het beroepssegment, dat wil zeggen het aantal schoolverlaters dat werkzaam is in de betreffende beroepen.

\section{Sorteren op risicoattitude: loonrisico}

Figuur 5.I laat zien dat er een positief verband bestaat tussen de gemiddelde carrière risicoattitude van schoolverlaters die werkzaam zijn in een beroep en het loonrisico in dat beroep. Een mogelijke interpretatie is dat schoolverlaters informatie gebruiken over het loonrisico in beroepen en op basis van hun voorkeuren een beroep kiezen dat het beste bij hen past. Eenzelfde verband wordt in figuur 5.2 gevonden voor het loonrisico bij de leeftijd van 40-49 jaar: een sterke risicoattitude gaat samen met de keuze voor een beroep met meer loonrisico later in de carrière. ${ }^{100}$

\section{Figuur 5.1}

Carrière risicoattitude van schoolverlaters en beroepsspecifiek loonrisico

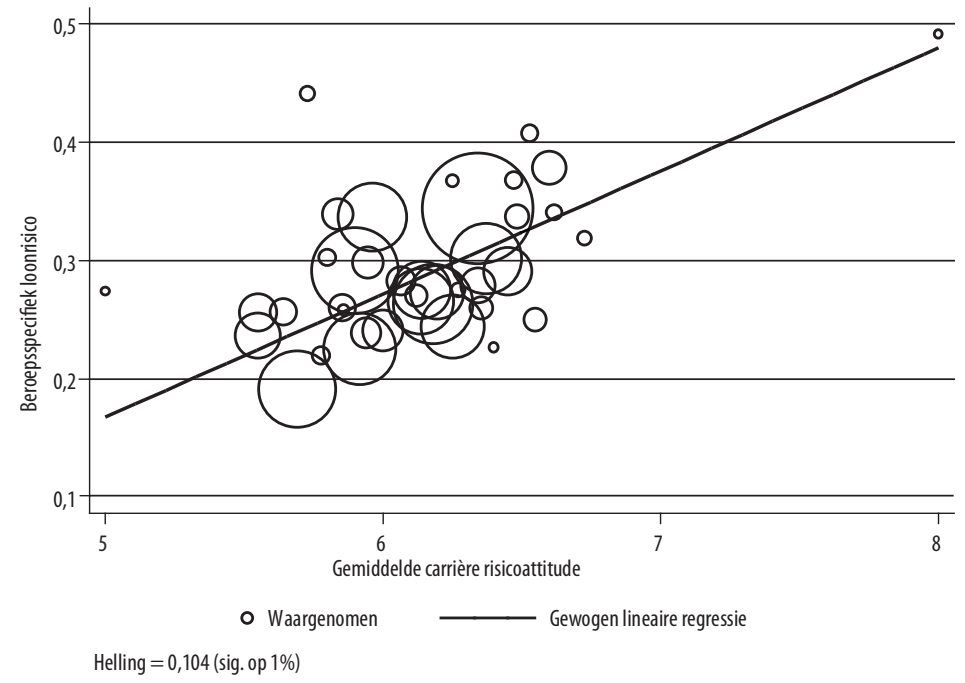

IOO. De verbanden in figuren 5.I t/m 5.5 blijven significant als de kleine beroepen met minder dan 30 schoolverlaters (in totaal I4 beroepssegmenten) uit de analyses worden gelaten. Vergelijkbare, zij het iets zwakkere, verbanden worden gevonden bij gebruik van de algemene risicoattitude in plaats van de carrière risicoattitude. 
Leraren en hogere medische en paramedische beroepen zijn voorbeelden van beroepen met een laag loonrisico. In dergelijke beroepen werken schoolverlaters met een lage risicoattitude. Managers en wetenschappelijke medische en paramedische beroepen zijn voorbeelden van beroepen met een hoog loonrisico. Schoolverlaters in dergelijke beroepen hebben een relatief sterke risicoattitude.

\section{Figuur 5.2}

Carrière risicoattitude van schoolverlaters en beroepsspecifiek loonrisico bij de leeftijd van 40-49 jaar

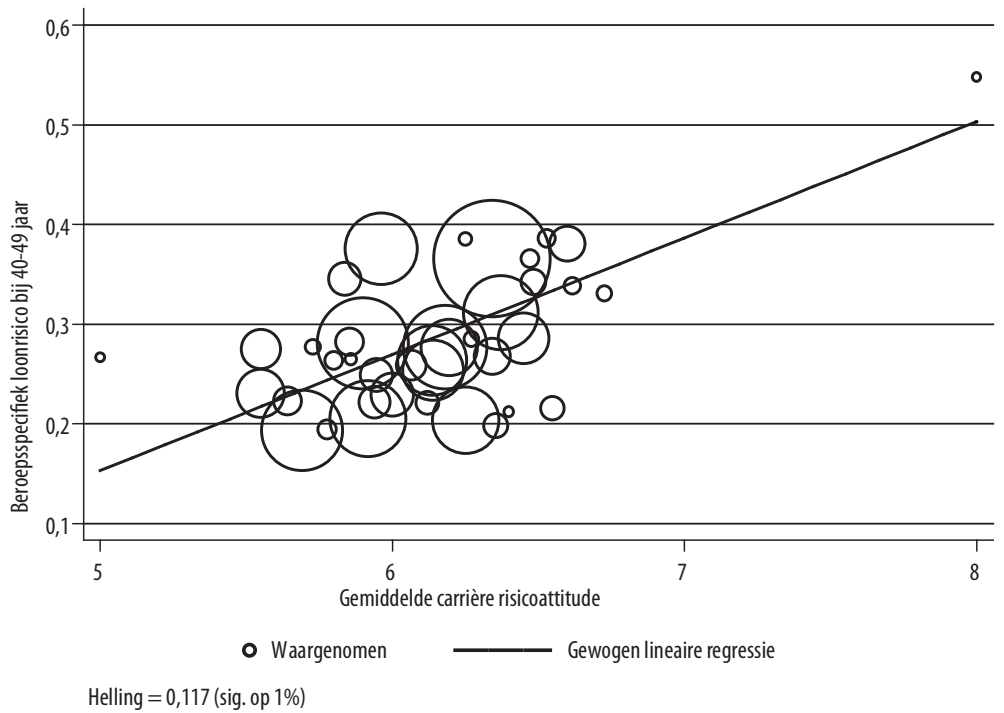

\section{Sorteren op risicoattitude: werkgelegenheidsrisico}

De relatie tussen risicoattitude en conjunctuurgevoeligheid wordt weergegeven in figuur 5.3. De figuur laat een positief verband zien tussen de sterkte van de risicoattitude en de conjunctuurgevoeligheid. Schoolverlaters met een sterke risicoattitude gaan werken in beroepen met een hoge mate van conjunctuurgevoeligheid. Voorbeelden van dergelijke beroepen zijn wetenschappelijke medische en paramedische beroepen, en hogere agrarische beroepen. Een vergelijkbaar positief verband wordt gevonden tussen risicoattitude en het werkloosheidsrisico (figuur 5.4). Voorbeelden van beroepen met een hoog werkloosheidsrisico zijn elementaire beroepen en lagere verzorgende beroepen. 
Figuur 5.3

Carrière risicoattitude van schoolverlaters en beroepsspecifieke conjunctuurgevoeligheid

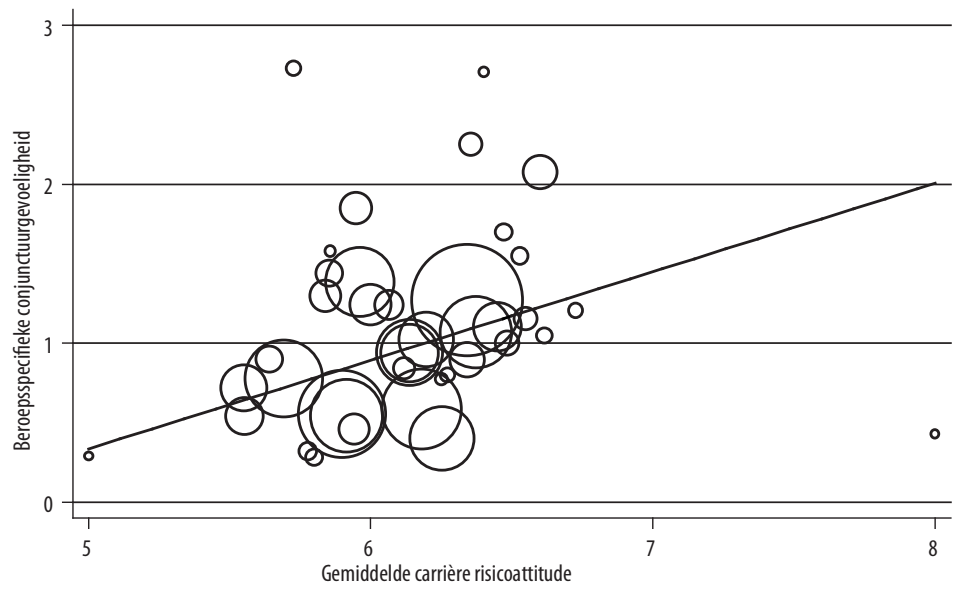

- Waargenomen

Gewogen lineaire regressie

Helling $=0,557$ (sig. op 1\%)

Figuur 5.4

Carrière risicoattitude van schoolverlaters en beroepsspecifiek werkloosheidsrisico

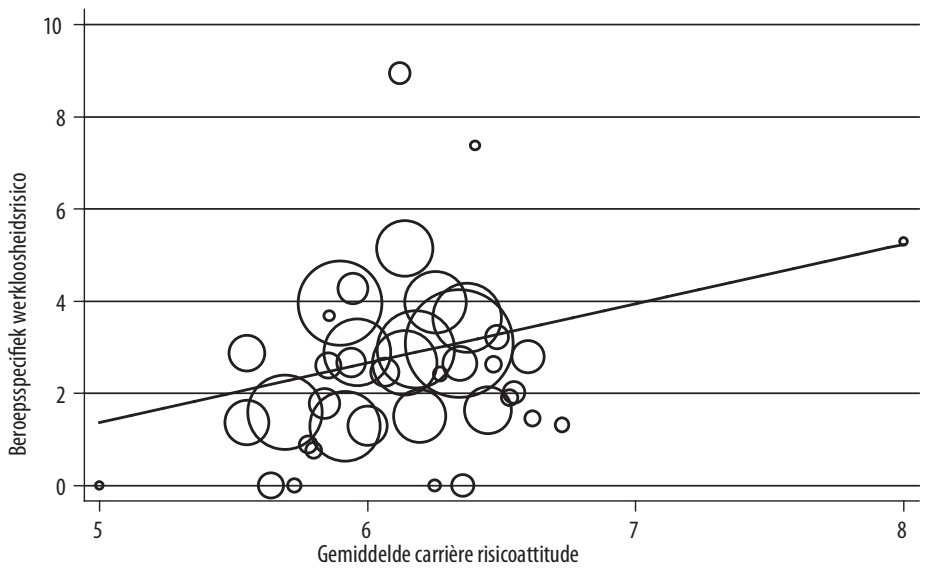

- Waargenomen

Gewogen lineaire regressie

Helling $=1,287$ (sig. op $1 \%$ ) 


\section{Sorteren op geduld: loongroei}

In figuur 5.5 wordt het gemiddelde geduld van schoolverlaters afgezet tegen de loongroei in het beroep. Het verband is positief en suggereert dat schoolverlaters met een sterke mate van geduld zich sorteren in beroepen met een sterker stijgend loonprofiel. Elementaire beroepen en lagere verzorgende beroepen zijn voorbeelden van beroepen met een beperkte loongroei. Schoolverlaters in deze beroepen hebben een lage mate van geduld. Wetenschappelijke medische en paramedische beroepen en wetenschappelijke wiskundige, natuurwetenschappelijke beroepen zijn voorbeelden van beroepen met een sterk stijgend loonprofiel. Schoolverlaters in deze beroepen hebben bovengemiddeld veel geduld.

\section{Figuur 5.5}

Geduld van schoolverlaters en beroepsspecifieke loongroei

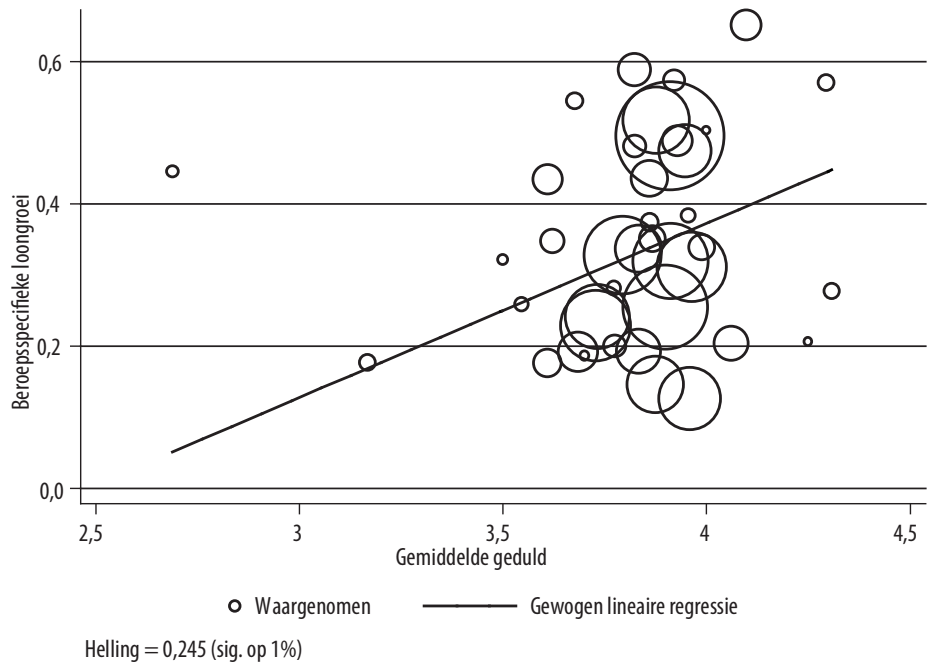

\section{Econometrische analyses}

Tabel 5.I laat de resultaten van econometrische analyses van kenmerken van beroepen en economische voorkeuren op individueel niveau. ${ }^{\text {Ior }}$ In de analyses wordt gecontroleerd voor leeftijd, geslacht, etniciteit, opleidingsniveau en Body Mass Index (BMI). Daarnaast wordt gecontroleerd voor persoonlijkheidskenmerken gemeten aan de hand van de vijf dimensies van de Big Five (open voor nieuwe ervaringen, zorgvuldig, extravert, meegaand, neurotisch). Er wordt gecontroleerd voor persoonlijkheid omdat het een rol kan spelen bij de beroepskeuze. Onderzoek laat overigens zien dat risicoat-

IoI. In de analyses zijn de afhankelijke variabelen en maatstaven voor economische voorkeuren gestandaardiseerd. 
titude en persoonlijkheid gecorreleerd zijn, en dat persoonlijkheid medebepalend is in een hele reeks economische beslissingen. ${ }^{\text {I02 }}$

De eerste kolom laat zien dat schoolverlaters met een sterkere risicoattitude een beroep met een groter loonrisico verkiezen. De interpretatie van de effecten is als volgt: als de carrière risicoattitude een standaarddeviatie is, resulteert dit in de keuze voor een beroep met een ongeveer 0,08 hoger loonrisico. De tabel laat ook positieve coëfficiënten zien voor risicoattitude en loonrisico bij leeftijd 40-49 jaar, conjunctuurgevoeligheid en werkloosheidsrisico. Ten aanzien van de grootte van de effecten blijkt risicoattitude het sterkst samen te hangen met het loonrisico en het loonrisico bij leeftijd 40-49 jaar. In het model blijkt geduld positief samen te hangen met de keuze voor beroepen met een steiler loonprofiel, maar het verband is zwak. In absolute termen is het effect van geduld zwakker dan het effect van risicoattitude. De coëfficiënten blijven ongewijzigd significant en van een vergelijkbare grootte wanneer de kleine beroepen met minder dan 30 schoolverlaters worden weggelaten.

\section{Tabel 5.1}

Effect van risicoattitude en geduld van schoolverlaters op beroepskeuze, gestandaardiseerde regressiecoëfficiënten

\begin{tabular}{llllll|} 
& Loonrisico & $\begin{array}{l}\text { Loonrisico bij leeftijd } \\
40-49 \text { jaar }\end{array}$ & $\begin{array}{l}\text { Conjunctuur- } \\
\text { gevoeligheid }\end{array}$ & $\begin{array}{l}\text { Werkloosheids- } \\
\text { risico }\end{array}$ & Loongroei \\
\hline Risicoattitude & $0,079^{* * *}$ & $0,067^{* * *}$ & $0,046^{* * *}$ & $0,052^{* * *}$ & \\
\hline Geduld & $(0,014)$ & $(0,014)$ & $(0,014)$ & $(0,014)$ & $0,019^{*}$ \\
\hline Controle variabelen ${ }^{\text {a) }}$ & Ja & & & & $(0,010)$ \\
\hline Adjusted R & & Ja & Ja & Ja & Ja \\
\hline N & 0,193 & 0,205 & 0,216 & 0,160 & 0,532 \\
\hline
\end{tabular}

Bron: ROA(SIS), CBS(SSB, EBB), Arbeidsaanbodpanel

a) Leeftijd (eerste, tweede en derde macht), geslacht, etniciteit (autochtoon, 1ste generatie allochtoon, 2de generatie allochtoon), opleidingsniveau (vmbo, havo/vwo, bbl, bol, hbo, wo), Body Mass Index en Big Five.

Opmerking: ${ }^{*}=$ significant op $10 \%$-niveau; ${ }^{* *}=$ significant op $5 \%$-niveau; ${ }^{* *}=$ significant op 1\%-niveau; standaardfouten tussen haakjes.

\subsection{Vaardigheden en compenserende loonverschillen}

In deze paragraaf wordt een aantal mogelijke problemen bij de hoofdresultaten van tabel 5.I besproken. Ten eerste wordt bij de analyses impliciet verondersteld dat schoolverlaters geen informatie hebben over hun eigen capaciteiten en vaardigheden waardoor zij niet kunnen inschatten waar zij terecht zullen komen in de loonverde-

I02. L. Borghans, B. Golsteyn, J. Heckman en H. Meijers (2009), 'Gender differences in risk aversion and ambiguity aversion', Journal of the European Economic Association, Vol. 7, pp. 649-658; M. Almlund, A. Duckworth, J. Heckman en T. Kautz (20II), Personality psychology and economics, IZA DP 5500, Bonn. 
ling. Het belang van deze veronderstelling wordt getoetst door te kijken naar de heterogeniteit in de effecten naar opleidingsniveau en door het toevoegen van additionele controlevariabelen in het model die iets zeggen over de niet-waargenomen vaardigheden van de schoolverlaters. Ten tweede wordt de mogelijkheid besproken dat de gebruikte maatstaf voor loonrisico niet zozeer de onzekerheid van het loon weerspiegelt, maar eerder de compenserende loonverschillen binnen en tussen beroepen. Dit betekent dat positieve of negatieve eigenschappen van banen zich vertalen in een lager of hoger loon dat niet gerelateerd is aan het loonrisico.

\section{Verschillen in vaardigheden}

Omdat de schoolverlaters van een verschillend opleidingsniveau zijn, kan men beargumenteren dat verschillen in, bijvoorbeeld, het loonrisico tussen beroepen samengaan met onderlinge verschillen in opleidingsniveau. Het zou immers kunnen dat hoogopgeleiden beter geïnformeerd zijn over hun eigen capaciteiten en vaardigheden dan laagopgeleiden. Daardoor kiezen zij vaker voor beroepen met een hoog loonrisico in de verwachting dat zij een loonpremie zullen ontvangen. ${ }^{103} \mathrm{Om}$ die redenen zijn de analyses in tabel 5.I herhaald voor verschillende opleidingsniveaus.

Voor hbo/wo'ers worden dezelfde resultaten als in tabel 5.I gevonden. Het enige verschil is dat het effect van geduld alleen significant is op I2\%. Voor schoolverlaters op vmbo-, mbo-, havo- en vwo-niveau zijn geen van de coëfficiënten significant. Een eerste mogelijke verklaring hiervoor is dat lager opgeleiden meer beperkt zijn in hun beroepskeuze. De beroepen waar ze toegang toe hebben zijn minder divers in het loon- en werkgelegenheidsrisico. Een tweede mogelijke verklaring is dat schoolverlaters op een lager niveau een ander keuzepalet hebben dan schoolverlaters op hbo niveau of hoger: voor veel schoolverlaters van het secundair onderwijs is de keuze om door te leren een reëel alternatief. Vanuit dit perspectief is er gekeken of risicoattitude samenhangt met de keuze om door te studeren. Hoewel het effect insignificant is vinden wij dat carrière risicoattitude negatief samenhangt met kans om door te leren: jongeren die meer bereid zijn om risico's te nemen zijn minder geneigd om door te leren. ${ }^{104}$ Ook blijkt dat geduld positief en significant samenhangt met de kans op doorleren: jongeren die gericht zijn op de toekomst zijn meer geneigd om door te leren. Een derde mogelijke verklaring voor het ontbreken van een relatie voor lager opgeleide schoolverlaters is dat zij geen goede perceptie hebben van de kenmerken van beroepen of het moeilijk vinden om deze informatie te betrekken op hun eigen gedrag. Op dit punt zou vervolgonderzoek van grote waarde zijn.

Het is goed mogelijk dat personen die hun eigen waarde op de arbeidsmarkt hoger inschatten, bijvoorbeeld doordat zij afgestudeerd zijn met een hoog schoolcijfer,

I03. Technisch gesproken: zij zouden kunnen verwachten om aan de rechterkant van de loonspreiding te zitten Een additioneel probleem zou kunnen zijn dat onze data relatief veel schoolverlaters op hbo en wo niveau bevatten.

I04. Zie ook C. Belzil en M. Leonardo (2007), Risk aversion and schooling decisions, IZA DP 2994, Bonn. 
het eerder aandurven om voor beroepen met een hoog loonrisico te kiezen omdat zij verwachten dat zij aan de bovenkant van de verdeling terecht zullen komen. De analyses zijn daarom herhaald met een extra controlevariabele voor schoolcijfers. Deze extra controlevariabele heeft geen invloed op onze bevindingen.

\section{Compenserende loonverschillen}

Een mogelijk kritiekpunt bij de analyses is dat het loonrisico (standaarddeviatie van de residuen uit de Mincer loonschatting) geen goede maatstaf zou zijn voor de onzekerheid van beloningen in beroepen. Zo zou de loonspreiding het gevolg kunnen zijn van compenserende lonen binnen en tussen beroepen. Om te bezien of de resultaten het gevolg zijn van compenserende loonverschillen is een additionele analyse uitgevoerd, waarbij expliciet rekening is gehouden met belastende arbeidsomstandigheden van de banen bij de berekening van het loonrisico.

\section{Tabel 5.2}

Effect van algemene risicoattitude op beroepskeuze (127 beroepsgroepen), model met en zonder controle voor belastende arbeidsomstandigheden

\begin{tabular}{|c|c|c|}
\hline \multicolumn{3}{|c|}{ Beroepsspecifiek loonrisico } \\
\hline & $\begin{array}{l}\text { Geen controle voor belastende } \\
\text { arbeidsomstandigheden }\end{array}$ & $\begin{array}{l}\text { Controle voor belastende } \\
\text { arbeidsomstandigheden }\end{array}$ \\
\hline \multirow[t]{2}{*}{ Algemene risicoattitude } & $0,046^{* *}$ & $0,047^{* * *}$ \\
\hline & $(0,018)$ & $(0,018)$ \\
\hline (ontrole variabelen ${ }^{\text {b) }}$ & $\mathrm{Ja}$ & $\mathrm{Ja}$ \\
\hline Adjusted $R^{2}$ & 0,014 & 0,017 \\
\hline \multicolumn{3}{|c|}{$\begin{array}{l}\text { Bron: Arbeidsaanbodpanel } \\
\text { a) Controle voor } 17 \text { belastende arbeidsomstandigheden in eerste ronde, bij bepaling van beroeps- } \\
\text { specifieke loonrisico. } \\
\text { b) Leeftijd (eerste, tweede en derde macht), geslacht, jaren gewerkt bij de werkgever (eerste en } \\
\text { tweede macht), etniciteit, opleidingsniveau. } \\
\text { Opmerking: }{ }^{*}=\text { significant op } 10 \% \text {-niveau; }{ }^{* *}=\text { significant op } 5 \% \text {-niveau; }{ }^{* * *}=\text { significant op } \\
1 \% \text {-niveau; standaardfouten tussen haakjes. }\end{array}$} \\
\hline
\end{tabular}

Op basis van het Arbeidsaanbodpanel kan expliciet rekening worden gehouden met belastende arbeidsomstandigheden. Het Arbeidsaanbodpanel bevat een uitgebreide lijst belastende arbeidsomstandigheden die gebruikt zijn bij het schatten van de beloningsfunctie. Op basis van de 2008 peiling van de data wordt een loonregressie geschat voor het uurloon (in log) waarbij gecontroleerd wordt voor geslacht, leeftijd, aantal dienstjaren, opleidingsniveau, beroepsdummies en 17 belastende arbeidsomstandigheden (zoals fysiek zwaar werk, werk met gevaarlijke producten, repetitieve taken, werk in koude/warme temperaturen, enz.). Het loonrisico wordt, per beroepssegment, net als bij de vorige analyses, berekend als de standaarddeviatie van de storingstermen. Omdat de 2008 peiling van het Arbeidsaanbodpanel de algemene risicoattitude vraag bevat zijn de analyses uit tabel 5.I herhaald met een maatstaf voor loonrisico die 'gezuiverd' is van mogelijke compenserende loonverschillen. De 
resultaten worden gepresenteerd in tabel 5.2 en suggereren dat de bevindingen met betrekking tot de relatie tussen risicoattitude en de sortering in banen met een hoog loonrisico niet het gevolg zijn van compenserende loonverschillen.

\subsection{Voorkeuren en mobiliteit}

Wanneer schoolverlaters zich op basis van hun economische voorkeuren sorteren in beroepen, dan kan men verwachten dat zij zullen reageren op een verkeerde match door van beroep te veranderen. Een verkeerde match - dat wil zeggen een beroep dat niet aansluit bij de voorkeur - kan het gevolg zijn van verkeerde informatie, onvoldoende investering in het verkrijgen of verwerken van informatie of van onvoldoende baanopeningen bij de intrede op de arbeidsmarkt. Om dit te onderzoeken zijn de loonrisico's voor 43 beroepssegmenten zoals die berekend zijn vanuit het SSB gekoppeld aan de 2006 en 2008 golven van het Arbeidsaanbodpanel. Er wordt gebruik gemaakt van de 2008 informatie over de algemene risicoattitude van respondenten. Er is sprake van een verkeerde match wanneer werkenden met een risicoattitude boven (onder) de mediaan gesorteerd zijn in een baan met loonrisico onder (boven) de mediaan in 2006. De kans op beroepsmobiliteit tussen 2006 en 2008 wordt gemodelleerd met een probit model, conditioneel op de kwaliteit van de match in 2006 en een aantal achtergrondkenmerken.

De resultaten in de eerste twee kolommen van tabel 5.3 laten zien dat personen die niet werkzaam zijn in een beroep dat correspondeert met hun voorkeur - omdat het loonrisico te hoog of juist te laag is vergeleken met hun risicoattitude - vaker van beroep veranderen dan personen die wel goed zijn gesorteerd. Dit roept de vraag op of de beroepsmobiliteit tot een meer efficiënte allocatie leidt, dat wil zeggen of mensen dan ook terechtkomen in beroepen die beter aansluiten bij hun voorkeuren. Dit blijkt inderdaad het geval. Werkenden met een hoge risicoattitude die werkzaam zijn in een beroep met een relatief laag loonrisico gaan vaker naar een beroep met meer loonrisico. Daarentegen, stappen werkenden met een lage risicoattitude die werkzaam zijn in een beroep met een relatief hoog loonrisico vaker over naar een beroep met minder loonrisico. Omdat deze resultaten opgaan voor volwassenen in het Arbeidsaanbodpanel waarbij het allocatieproces al grotendeels heeft plaatsgevonden en de mogelijkheden om voor een ander beroep te kiezen beperkter zijn dan voor jongeren, kan verwacht worden dat de resultaten voor schoolverlaters nog sterker zijn. 
Tabel 5.3

Econometrische analyse voor beroepsmobiliteit tussen 2006 en 2008, probit coëfficiënten

\begin{tabular}{|c|c|c|c|c|}
\hline & $\begin{array}{l}\text { Verandering van } \\
\text { beroep }\end{array}$ & $\begin{array}{l}\text { Verandering van } \\
\text { beroep }\end{array}$ & $\begin{array}{l}\text { Verandering naar } \\
\text { beroep met meer } \\
\text { loonrisico }\end{array}$ & $\begin{array}{l}\text { Verandering } \\
\text { naar beroep met } \\
\text { minder loonrisico }\end{array}$ \\
\hline \multirow[t]{2}{*}{ Verkeerde match (algemene risicoattitude) } & $0,120^{* *}$ & $0,117^{* *}$ & & \\
\hline & $(0,052)$ & $(0,053)$ & & \\
\hline \multirow[t]{2}{*}{$\begin{array}{l}\text { Hoge risicoattitude, maar gesorteerd in } \\
\text { beroep met laag loonrisico }\end{array}$} & & & $0,431^{* * *}$ & \\
\hline & & & $(0,072)$ & \\
\hline \multirow[t]{2}{*}{$\begin{array}{l}\text { Lage risicoattitude, maar gesorteerd in beroep } \\
\text { met hoog loonrisico }\end{array}$} & & & & $0,358^{* * *}$ \\
\hline & & & & $(0,063)$ \\
\hline (ontrole variabelen ${ }^{\text {a) }}$ & Nee & $\mathrm{Ja}$ & $\mathrm{Ja}$ & $\mathrm{Ja}$ \\
\hline Pseudo R-kwadraat & 0,002 & 0,022 & 0,022 & 0,021 \\
\hline \multicolumn{5}{|c|}{$\begin{array}{l}\text { Bron: Arbeidsaanbodpanel } \\
\text { a) Leeftijd (eerste, tweede en derde macht), geslacht, jaren gewerkt bij de werkgever (eerste en } \\
\text { tweede macht), etniciteit, opleidingsniveau. } \\
\text { Opmerking: }{ }^{*}=\text { significant op } 10 \% \text {-niveau; }{ }^{* *}=\text { significant op } 5 \% \text {-niveau; }{ }^{* *}=\text { significant op } \\
1 \% \text {-niveau; standaardfouten tussen haakjes. }\end{array}$} \\
\hline
\end{tabular}

\subsection{Conclusie}

De analyses in dit themahoofdstuk laten zien dat economische voorkeuren (risicoattitude en geduld) van schoolverlaters medebepalend zijn voor hun beroepskeuze. Zo blijken schoolverlaters met een sterke risicoattitude vaker te kiezen voor beroepen met een hoog loonrisico. Ook blijken ze vaker te kiezen voor beroepen waarin het werkgelegenheidsrisico hoog is: beroepen waarin de conjunctuurgevoeligheid en het risico op werkloosheid hoog is. Schoolverlaters met veel geduld kiezen vaker voor beroepen met een steil loonprofiel, dat wil zeggen beroepen waarin het loon sterk stijgt met de leeftijd. Hoewel de resultaten vooral opgaan voor hoogopgeleiden suggereren deze bevindingen dat de relatie tussen voorkeuren en beroepskeuzen causaal is omdat het gaat om schoolverlaters die aan het begin staan van hun loopbaan en hun beroepskeuze moeten maken, en dus niet langdurig zijn blootgesteld aan bepaalde beroepskenmerken. Vervolganalyse zou zich moeten richten op de vraag in welke mate economische voorkeuren bepalend zijn voor de studiekeuze. Nader onderzoek is ook noodzakelijk om beter inzicht te krijgen in de studiekeuze en beroepskeuze van lager opgeleiden. Dergelijk onderzoek zou zich kunnen richten op de percepties van lager opgeleiden ten aanzien van hun eigen vaardigheden en hun perceptie van beroeps- en opleidingskenmerken.

Analyses van het Arbeidsaanbodpanel laten verder zien dat personen die 'verkeerd' gesorteerd zijn - dat wil zeggen, zij zitten in een beroep met weinig loonrisico terwijl 
zij een sterke risicoattitude hebben, of andersom - vaker van beroep veranderen vergeleken met personen die correct gesorteerd zijn. Het nieuwe beroep past beter bij de eigen economische voorkeuren. Dit geeft aan dat beroepsmobiliteit voor een belangrijk deel corrigeert voor verkeerde allocatie van arbeid. Dit suggereert dat betere informatie over beroepskenmerken de initiële allocatie van arbeid zou kunnen verbeteren.

De bevindingen in dit themahoofdstuk geven aanleiding tot een aantal conclusies. In de eerste plaats, wijzen de resultaten in dit hoofdstuk op de noodzaak van publicatie van gedetailleerde informatie over beroepsrisico's (rond loon, baanvindkans, mogelijkheden voor opwaartse loonmobiliteit, maar ook andere beroepsrisico's). Dit is van belang omdat economische voorkeuren medebepalend zijn voor de beroepskeuze. Op basis van dergelijke informatie kunnen schoolverlaters en andere werkenden tot een betere beroepskeuze komen. Dit vergroot de allocatieve efficiëntie van menselijk kapitaal in banen. In de tweede plaats wijzen de resultaten erop dat veranderingen in beroepskenmerken die van invloed zijn op de beloningsstructuur mogelijk onbedoelde effecten kunnen hebben. De invoering van variabele beloning of prestatiebeloning kan bijdragen tot meer motivatie onder werknemers, maar het vergroot ook het loonrisico. Dat laatste kan er toe leiden dat de samenstelling van de beroepsgroep onbedoeld veranderd: het beroep wordt immers aantrekkelijker voor werkenden met een sterke risicoattitude. Daarnaast kan het negatieve gevolgen hebben voor de werktevredenheid van de zittende werknemers in het betreffende beroep omdat zij voor een beroep hebben gekozen op basis van andere informatie. Zij kunnen dan uiteraard weer voor een ander beroep gaan kiezen, maar dergelijke beroepsmobiliteit impliceert een verlies van beroepsspecifiek menselijk kapitaal. 


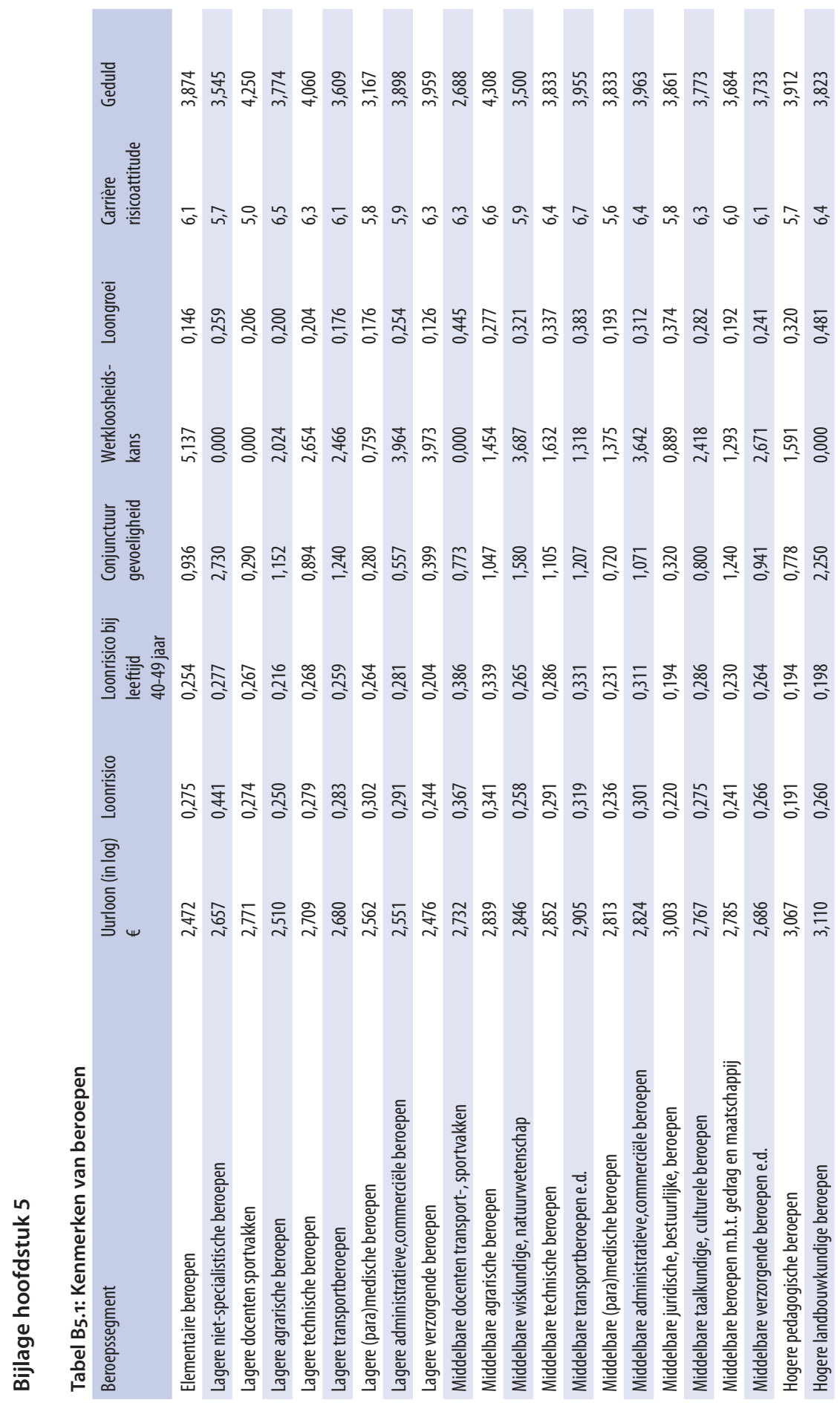




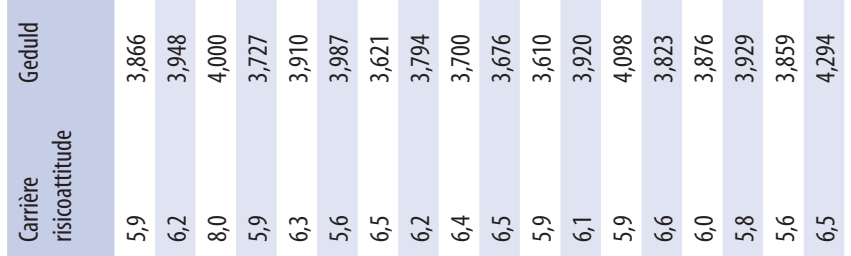

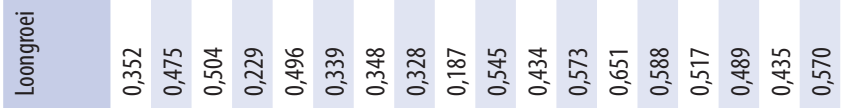

㐫

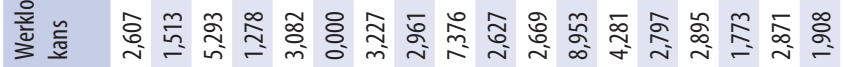

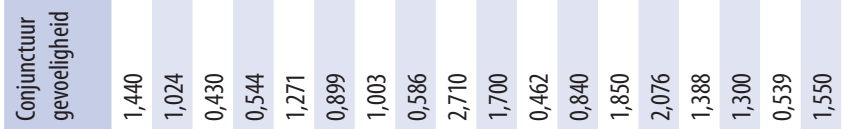

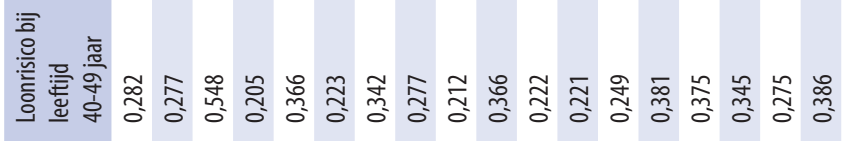

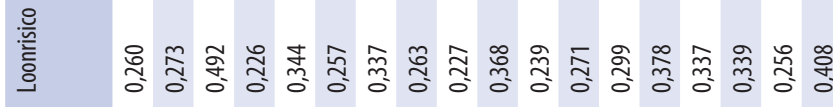

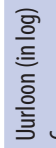

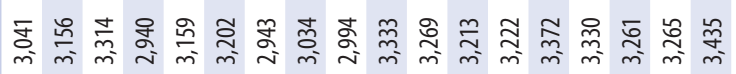

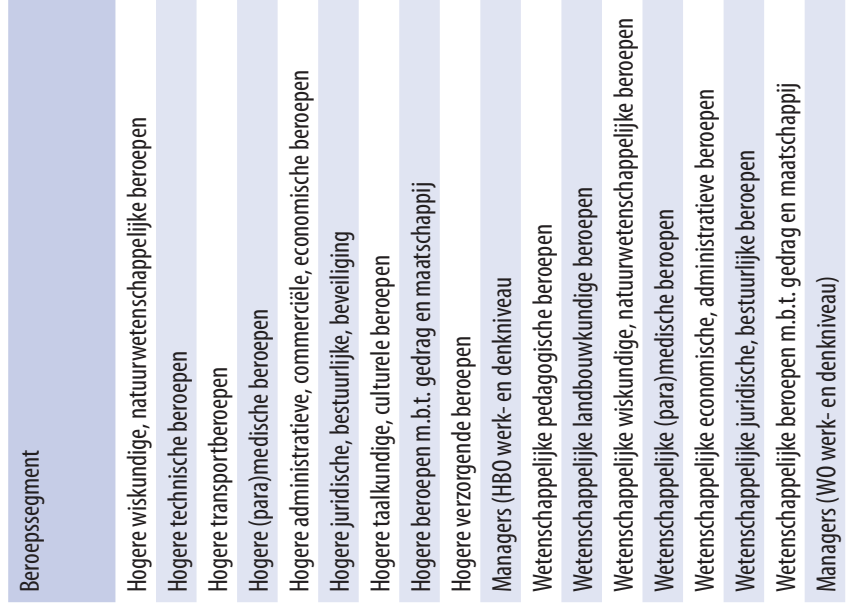




\section{Tabel B5.2}

Top vijf van beroepssegmenten, naar geselecteerde beroepskenmerken

\begin{tabular}{|c|c|}
\hline \multicolumn{2}{|l|}{ Loonrisico } \\
\hline Vijf beroepen met hoogste loonrisico & Vijf beroepen met laagste loonrisico \\
\hline Managers (HBO werk- en denkniveau) & Hogere pedagogische beroepen \\
\hline Wetenschappelijke (para)medische beroep & Middelbare juridische, bestuurlijke, beroepen \\
\hline Managers (WO werk- en denkniveau) & Hogere (para)medische beroepen \\
\hline Lagere niet-specialistische beroepen & Hogere verzorgende beroepen \\
\hline Hogere transportberoepen & Middelbare (para)medische beroepen \\
\hline \multicolumn{2}{|l|}{ Conjunctuurgevoeligheid } \\
\hline Vijf beroepen met hoogste conjunctuur gevoeligheid & Vijf beroepen met laagste conjunctuur gevoeligheid \\
\hline Wetenschappelijke wiskundige, natuurwetenschappelijke beroepen & Lagere (para)medische beroepen \\
\hline Wetenschappelijke (para)medische beroep & Lagere docenten sportvakken \\
\hline Hogere landbouwkundige beroepen & Middelbare juridische, bestuurlijke, beroepen \\
\hline Hogere verzorgende beroepen & Lagere verzorgende beroepen \\
\hline Lagere niet-specialistische beroepen & Hogere transportberoepen \\
\hline \multicolumn{2}{|l|}{ Loongroei } \\
\hline Vijf beroepen met hoogste loongroei & Vijf beroepen met laagste loongroei \\
\hline Managers ( $\mathrm{HBO}$ werk- en denkniveau) & Lagere verzorgende beroepen \\
\hline Managers (W0 werk- en denkniveau) & Elementaire beroepen \\
\hline Wetenschappelijke landbouwkundige beroepen & Lagere transportberoepen \\
\hline Wetenschappelijke (para)medische beroepen & Lagere (para)medische beroepen \\
\hline Wetenschappelijke wiskundige, natuurwetenschappelijke beroepen & Hogere verzorgende beroepen \\
\hline
\end{tabular}





\title{
Bijlage A \\ Enkele centrale begrippen ${ }^{105}$
}

\begin{abstract}
Allochtoon
Het begrip allochtoon wordt gehanteerd volgens de (nieuwe) standaarddefinitie van het CBS. De definitie van allochtoon heeft betrekking op iedereen waarvan ten minste één ouder in het buitenland is geboren. Het buitenland is daarbij op te splitsen in westerse en niet-westerse herkomstlanden. Tot de niet-westerse herkomstlanden worden gerekend Turkije en alle landen in Afrika, Latijns-Amerika en Azië (met uitzondering van Japan en Indonesië). De definitie van de allochtonen naar herkomst heeft in dit rapport betrekking op de niet-westerse herkomstlanden.
\end{abstract}

\section{Arbeidsmarktinstroom van schoolverlaters}

Het aanbod van nieuwe arbeidskrachten op de arbeidsmarkt, zoals deze is bepaald door de verwachte uitstroom van schoolverlaters uit het initiële dagonderwijs, de schoolverlaters van het deeltijdonderwijs, het niet-reguliere voltijdonderwijs en de beroepsgerichte volwasseneneducatie. Daarbij wordt de benaming 'schoolverlater' meestal ook gehanteerd voor de afgestudeerden van het hoger onderwijs.

\section{Publicaties:}

A. de Grip en A. Jacobs (1999), De doorstroom van het initieel naar het niet-initieel onderwijs, ROA-W-I999/3, Universiteit Maastricht.

F. Cörvers en B. Golsteyn (2003), De invloed van voortijdige schooluitval op de instroomprognoses van schoolverlaters op de arbeidsmarkt, ROA-W-2003/I, Universiteit Maastricht.

I05. Een nadere toelichting op de gehanteerde begrippen en het prognosemodel is ook te vinden aan het begin van dit rapport en in ROA, Methodiek arbeidsmarktprognoses en -indicatoren 20II-20I6, Universiteit Maastricht, te verschijnen. 


\section{Arbeidsvolume}

Het totaal aantal arbeidsjaren, waarbij is uitgegaan van een werkweek van 40 uur.

\section{Baanopeningen}

De totale vraag naar nieuwkomers op de arbeidsmarkt, zoals deze is bepaald door de werkgelegenheidsgroei (positieve uitbreidingsvraag) en de vervangingsvraag. Bij het vaststellen van het aantal baanopeningen wordt ermee rekening gehouden dat het aannemen van schoolverlaters door bedrijven en instellingen ('de vraag naar schoolverlaters') op nagenoeg hetzelfde niveau blijft ondanks een eventuele werkgelegenheidskrimp vanwege de extra uitstroom van ouderen. Het blijkt dat werkgevers voor het realiseren van een teruglopende vraag naar arbeid aan de 'exit'-optie de voorkeur geven boven de 'no entry'-optie van bijvoorbeeld schoolverlaters. Een werkgelegenheidskrimp voor een opleidingstype of beroepsgroep gaat derhalve nauwelijks ten koste van de vervangingsvraag of het aantal baanopeningen in een opleidingstype of beroepsgroep.

\section{Publicaties:}

A. de Grip, P. Meijboom and E. Willems (1994), 'Vacancies, Employment Growth and the Demand for Newcomers on the Labour Market', in: J. Muijsken (ed.), Measurement and Analysis of Job Vacancies, Avebury, Aldershot/Brookfield (USA), pp. IOI-I25.

E. Willems, L. Borghans and A. de Grip (1997), Exit or no entry? Replacement demand and shrinking employment, ROA, Paper for the EALE conference, Aarhus, Denmark.

\section{Bedrijfssector}

De in dit rapport gepresenteerde informatie is veelal verbijzonderd naar 32 bedrijfssectoren (zie Bijlage B). Deze indeling is gebaseerd op de Standaard Bedrijfsindeling I993 (SBI '93) van het CBS. De prognoses van de uitbreidingsvraag zijn echter een aggregatie van de 32 bedrijfssectoren, en zijn verbijzonderd naar Is bedrijfssectoren. Deze laatste indeling sluit aan bij de bedrijfssectorindeling van het CPB en EIM.

\section{Publicatie:}

Researchcentrum voor Onderwijs en Arbeidsmarkt (2007), Classificaties 2007, Digitaal informatiesysteem, Universiteit Maastricht. 


\section{Beroepsgroep}

In dit rapport wordt uitgegaan van 127 beroepsgroepen over de volle breedte van de arbeidsmarkt. Deze zijn geclusterd tot II beroepsklassen (zie Bijlage B). De indeling van 127 beroepsgroepen komt overeen met de Standaard Beroepenclassificatie I992 (SBC '92) van het CBS.

\section{Publicaties:}

Researchcentrum voor Onderwijs en Arbeidsmarkt (2002), ROA-classificatiegids 2002, ROA-R-2002/3, Universiteit Maastricht.

Researchcentrum voor Onderwijs en Arbeidsmarkt (2007), Classificaties 2007, Digitaal informatiesysteem, Universiteit Maastricht.

\section{Beroepsbevolking}

De beroepsbevolking omvat de werkenden en de werkzoekenden zonder baan. Iedereen met een leeftijd tussen de 15 en 64 jaar, die minstens I2 uur per week betaalde arbeid verricht of zou willen verrichten wordt tot de beroepsbevolking gerekend. Als men reeds meer dan 12 uur per week werkt, wordt men tot de werkzame beroepsbevolking gerekend. Werkt men niet of minder dan I2 uur, maar wil men wel minstens I2 uur per week betaalde arbeid verrichten, dan behoort men tot de werkloze beroepsbevolking. De definities van de beroepsbevolking zijn afkomstig van het CBS (www. cbs.nl).

\section{Conjunctuurgevoeligheid}

De conjunctuurgevoeligheid van de werkgelegenheid heeft betrekking op de mate waarin de werkgelegenheid in een beroepsgroep, of voor mensen met een bepaalde opleidingsachtergrond, gevoelig is voor veranderingen van de economische situatie. Deze indicator geeft daarmee de mate van werkzekerheid aan. De conjunctuurgevoeligheid wordt bepaald door de sectorale werkgelegenheidsfluctuaties in het verleden te relateren aan de mate waarin een beroepsgroep of opleidingstype momenteel in de verschillende bedrijfssectoren is vertegenwoordigd. Hierbij wordt rekening gehouden met het feit dat niet ieder beroep even sterk meefluctueert met de werkgelegenheidsschommelingen van de bedrijfssector.

\section{Flexibele arbeidsrelatie}

Van een flexibele arbeidsrelatie is sprake bij uitzendkrachten, oproepkrachten, invalskrachten, contracten zonder een vast aantal arbeidsuren en indien geen vast dienst- 
verband is overeengekomen. Een arbeidscontract wordt als niet-vast beschouwd als de contractuele termijn van beperkte duur is.

\section{Publicatie:}

F. Cörvers, J. van Thor (20IO), Flexwerk in Nederland, ROA-TR-20Io/2, Universiteit Maastricht.

\section{Knelpunten in de personeelsvoorziening naar beroep}

Om inzicht te verschaffen hoe de aansluitingsproblematiek tussen onderwijs en arbeidsmarkt zijn weerslag heeft op de wervingsproblematiek in de verschillende beroepsgroepen, wordt gebruik gemaakt van de Indicator Toekomstige Knelpunten in de Personeelsvoorziening naar Beroep (ITKB). De ITKB geeft aan in welke mate het voor werkgevers mogelijk is om de gewenste personeelssamenstelling naar opleidingsachtergrond binnen beroepsgroepen te realiseren, bij de voorspelde vraag-aanbodverhoudingen voor de verschillende opleidingstypen. De ITKB heeft een waarde tussen $\mathrm{O}$ en I. Naarmate de waarde van de indicator lager is, zijn de knelpunten in de personeelsvoorziening voor de betreffende beroepsgroep groter. Werkgevers zullen dan relatief veel moeite hebben nieuw personeel met de door hen gewenste opleidingsachtergrond te vinden. Wanneer de ITKB daarentegen bijna gelijk is aan I, zullen werkgevers weinig moeite hebben de gewenste personeelssamenstelling binnen het beroep te realiseren. Voor die opleidingen die aandacht schenken aan de in dat beroep relevante kennis en vaardigheden, worden dan geringe knelpunten verwacht.

\section{Knelpunten in de personeelsvoorziening naar opleiding}

Als de vraag naar werkenden met een bepaalde opleidingsachtergrond groter is dan het aanbod kunnen knelpunten in de personeelsvoorziening voor werkgevers verwacht worden. Vergelijkbaar met de Indicator Toekomstig Arbeidsmarktperspectief (ITA) geeft de Indicator van de Toekomstige Knelpunten in de Personeelsvoorziening (ITKP) deze vraag-aanbod-spanning per opleidingstype aan. Verschil met de ITA is dat bij de ITKP de uitstroom van werkenden als gevolg van een krimpende werkgelegenheid is meegerekend in de vraag, omdat verwacht mag worden dat bij knelpunten in de personeelsvoorziening deze (gedwongen) uitstroom kan worden afgeremd of elders werk zou kunnen vinden. Naarmate de waarde van de indicator lager wordt, zijn de verwachte knelpunten groter. 


\section{Onderbenutting}

Een indicatie van de mate waarin arbeidskrachten werkzaam zijn op een functieniveau dat lager is dan hun opleidingsniveau. De mate van onderbenutting is vastgesteld door de schoolverlaters aan te laten geven in hoeverre de werkgever het verworven opleidingsniveau vereist voor de uitgeoefende functie.

\section{Publicatie:}

J. Coenen, F. Cörvers, D. Fouarge, C. Meng, A. Nelen (2009), 'Onderbenutting van mbo'ers nuttig op de arbeidsmarkt?', TPEdigitaal, Vol. 3, pp. IO3-I23.

\section{Opleidingstype}

Alle voorkomende opleidingen zijn samengevoegd tot een aantal clusters. In dit rapport worden IO2 opleidingstypen onderscheiden. Deze zijn geclusterd tot 23 opleidingscategorieën (zie Bijlage B). De opleidingsindeling is gekoppeld aan de Standaard Onderwijsindeling I998 (SBI'98) van het CBS.

\section{Publicaties:}

Researchcentrum voor Onderwijs en Arbeidsmarkt (2002), ROA-classificatiegids 2002, ROA-R-2002/3, Universiteit Maastricht.

H. Heijke, A. Matheeuwsen and E. Willems (2003), 'Clustering Educational Categories in a Heterogeneous Labour Market', Education Economics, Vol. II, pp. 89-108.

Researchcentrum voor Onderwijs en Arbeidsmarkt (2007), Classificaties 2007, Digitaal informatiesysteem, Universiteit Maastricht.

\section{Potentiële beroepsbevolking}

De potentiële beroepsbevolking omvat alle personen tussen de I5 en de 64 jaar, voor zover hun belangrijkste activiteit niet studie betreft. Scholieren en studenten worden dus niet tot de potentiële beroepsbevolking gerekend. De potentiële beroepsbevolking omvat daarmee naast de beroepsbevolking ook de niet-participerenden.

\section{Startkwalificatie}

Het Nederlandse onderwijsbeleid is erop gericht om jongeren minimaal een startkwalificatie te laten behalen, dat wil zeggen een opleiding overeenkomend met niveau 2 (basisberoepsbeoefenaar) van de kwalificatiestructuur voor de beroepsopleidende leerweg (BOL) en de beroepsbegeleidende leerweg (BBL) van het secundair beroepsonderwijs. Ook de tweede fase VO (HAVO of VWO) leidt tot een startkwalificatie. 
Globaal betekent dit dat na het verlaten van het VMBO nog een beroepsopleiding moet worden gevolgd via de BOL of de BBL met een minimale opleidingsduur van 2 jaar (voorheen tweejarig KMBO respectievelijk primair leerlingwezen). De startkwalificatie - of het niveau van basisberoepsbeoefenaar - wordt gezien als het niveau dat minimaal noodzakelijk is om op een goede manier te kunnen functioneren op de snel veranderende arbeidsmarkt. De grens tussen wel of geen startkwalificatie is vanuit arbeidsmarktoptiek gelegen rond niveau I of 2. De verschillende niveaus binnen het $\mathrm{MBO}$ kunnen in dit rapport meestal niet als zodanig worden onderscheiden. Om deze reden wordt een opleiding op MBO-niveau 2, 3 of 4 doorgaans beschouwd als een startkwalificatie voor de arbeidsmarkt, tenzij anders is aangegeven. Alle opleidingen van $\mathrm{MBO}$-niveau I (assistent beroepsbeoefenaar) zijn in dit rapport ingedeeld op VMBO-niveau.

\section{Publicaties:}

R. van der Velden, R. de Vries, M. Wolbers en P. van Eijs (2002), De waarde van een startkwalificatie, ROA-R-2002/I4, Universiteit Maastricht.

W.A. Houtkoop, R.K.W. van der Velden en T.F. Brandsma (2004), De waarde van de startkwalificatie, Max Goote bve, mei.

\section{Substitutie-effect (passief en actief)}

Als gevolg van discrepanties tussen vraag en aanbod op de arbeidsmarkt treden er verschuivingen op in de werkgelegenheidsstructuur. Schoolverlaters in een aanbodoverschotsituatie kunnen anders opgeleiden gaan verdringen, terwijl werkgevers die te kampen hebben met een tekortschietend arbeidsaanbod, personen met een andere opleidingsachtergrond kunnen gaan werven. De vraag die hierdoor verloren gaat of ontstaat wordt aangeduid als het passieve substitutie-effect. Als het passieve substitutie-effect positief is, gaat het om extra baanopeningen als gevolg van tekorten bij andere opleidingen. Een negatief substitutie-effect duidt daarentegen op een verlies aan baanopeningen, omdat men verdrongen wordt door andere opleidingen. Het actieve substitutie-effect geeft - als het positief is - aan in hoeverre werkenden met een opleidingsachtergrond waarvoor er een aanbodoverschot is door een verhevigde concurrentie alsnog werk zullen vinden door arbeidskrachten met een andere opleidingsachtergrond te verdringen. Een negatieve actieve substitutie geeft daarentegen aan welke werkgelegenheid niet meer vervuld zal worden als gevolg van de verwachte aanbodtekorten.

\section{Publicaties:}

L. Borghans and H. Heijke (1994), 'Forecasting the educational structure of occupations: A manpower requirement approach with substitution', Labour, Vol. Io, pp. I5I-I92.

A. de Grip, L. Borghans and W. Smits (1998), 'Future developments in the job level and domain of highly-skilled workers', in: H. Heijke, L. Borghans (eds), Towards a 
transparent Labour Market for Educational Decisions, Ashgate, Aldershot/Brookfield USA/Singapore/Sydney, pp. 2I-56.

F. Cörvers and H. Heijke (2004), Forecasting the labour market by occupation and education: Some key issues, ROA-W-2004/4, Universiteit Maastricht.

\section{Substitutiemogelijkheden bij de personeelswerving}

De mate waarin werkgevers voor een bepaald beroep arbeidskrachten kunnen aantrekken met een uiteenlopende opleidingsachtergrond, zodat ze niet afhankelijk zijn van het arbeidsaanbod van een bepaald opleidingstype. De substitutiemogelijkheden worden bepaald met behulp van een spreidingsindex.

\section{Toekomstig arbeidsmarktperspectief naar opleiding}

Het toekomstig arbeidsmarktperspectief geeft de verhouding tussen aanbod en vraag in de prognoseperiode voor een opleidingstype weer. De vraag- en aanbodprognoses zijn gebaseerd op de actuele arbeidsmarktpositie van een opleiding. Als het arbeidsmarktperspectief van een opleiding slecht is, betekent dit dat er de komende jaren veel meer aanbod van nieuwkomers is dan baanopeningen. Hierdoor zal de arbeidsmarktpositie gaan verslechteren. Deze verslechtering kan een hogere werkloosheid betekenen, maar door aanpassingsprocessen op de arbeidsmarkt kan de verslechtering van de arbeidsmarktsituatie ook leiden tot het moeten aanvaarden van banen op een lager niveau, een lagere beloning en meer tijdelijke contracten. Omgekeerd zal een goed perspectief leiden tot een grotere kans op werk, maar ook tot een verbeterde positie op andere punten. Het toekomstig arbeidsmarktperspectief per opleidingstype wordt bepaald door middel van de Indicator Toekomstig Arbeidsmarktperspectief (ITA), die is gedefinieerd als de verhouding tussen enerzijds de verwachte arbeidsmarktinstroom van schoolverlaters en het aantal kortdurig werklozen en anderzijds de verwachte baanopeningen en de passieve substitutievraag. Naarmate de waarde van de indicator hoger is wordt het perspectief slechter.

\section{Publicaties:}

M.H. Wieling, A. de Grip en E.J.T.A. Willems (1990), Een systematische kwalitatieve typering van arbeidsmarktinformatie, ROA-W-I990/8, Universiteit Maastricht.

F. Cörvers, A. de Grip and H. Heijke (2002), 'Beyond manpower planning: a labour market model for the Netherlands and its forecasts to 2006', in M. Neugart and K. Schömann (eds), Forecasting Labour Markets in OECD Countries, Cheltenham (UK) and Northampton MA (USA), Edward Elgar, pp. I85-223.

A. Dupuy (2009), An evaluation of the indicator of the labour market gap, ROA-TR2009/I, Universiteit Maastricht. 


\section{Uitbreidingsvraag}

De vraag naar nieuwe arbeidskrachten die ontstaat door groei van de werkgelegenheid. Als er sprake is van een werkgelegenheidsdaling, is de uitbreidingsvraag negatief.

\section{Publicaties:}

F. Cörvers and A. Dupuy (2006), Explaining the Occupational Structure of Dutch Sectors of Industry, 1988-2003, ROA-W-2006/7E, Universiteit Maastricht.

F. Cörvers en A. Dupuy (2007), Beroepenmodel voor het onderwijs en de zorg: werkgelegenheid en prognoses, ROA-W-2007/3, Universiteit Maastricht.

F. Cörvers and A. Dupuy (20I0), 'Estimating employment dynamics across occupations and sectors of industry', Journal of Macroeconomics, Vol. 32, pp. 17-27.

D. Bertrand-Cloodt (2010), Evaluatie uitbreidingsvraag en indicator toekomstige arbeidsmarktsituatie (ITA) tot 2008, ROA-TR-20Io/6, Universiteit Maastricht

\section{Uitwijkmogelijkheden}

De mate waarin arbeidskrachten met een bepaalde opleidingsachtergrond of met een bepaald beroep terecht kunnen komen in andere beroepsgroepen op een aansluitend of hoger functieniveau, respectievelijk in andere bedrijfssectoren. Deze maatstaf geeft daarmee aan in hoeverre arbeidskrachten afhankelijk zijn van de arbeidsmarktsituatie in een bepaald beroep of een bepaalde bedrijfssector. De uitwijkmogelijkheden worden bepaald met behulp van een spreidingsindex. Deze index geeft een indicatie van het aantal beroepsgroepen of bedrijfssectoren waarnaar men kan uitwijken.

\section{Publicatie:}

L. Borghans and H. Heijke (1998), 'Flexibility and the Structure of the Dutch Labour Market', in: H. Heijke, L. Borghans (eds), Towards a transparent Labour Market for Educational Decisions, Ashgate, Aldershot/Brookfield USA/Singapore/Sydney, pp. II9-I5O.

\section{Upgrading}

Door een toenemende complexiteit van de te verrichten werkzaamheden kunnen er voor een bepaald beroep door werkgevers hogere opleidingseisen worden gesteld. In dat geval spreekt men van upgrading van de kwalificatie-eisen. Overigens kan ook een verschuiving van de werkgelegenheid van lagere naar hogere beroepen als een upgradingsproces worden getypeerd.

\section{Publicaties:}

L. Borghans and A. de Grip (2000), Skills and Low Pay: 'Upgrading or Overeducation?', in: M. Gregory, W. Salverda and S. Bazen (eds), Labour Market Inequalities, Problems 
and Policies of Low-Wage Employment in International Perspective, Oxford University Press, Oxford, pp. 198-223.

A. Dupuy (2006), Measuring Skill-upgrading in the Dutch Labor Market, ROA-W2006/3E, Universiteit Maastricht.

A. Dupuy (2007), 'Will the skill-premium in the Netherlands rise in the next decades?', Applied Economics, Vol. 39, pp. 2723-273I.

\section{Verdringing}

Indien de arbeidskrachten met een bepaalde opleidingsachtergrond vanwege een aanbodoverschot bij een ander opleidingstype, te kampen hebben met een dalend werkgelegenheidsaandeel in de beroepen waarin zij werkzaam zijn, is er sprake van verdringing. Meer technisch wordt dit ook wel aangeduid als een negatief passief substitutie-effect. Bij het opleidingstype dat de anders opgeleiden verdringt is er sprake van een positief actief substitutie-effect.

\section{Publicaties:}

A. de Grip, L. Borghans and W. Smits (I998), 'Future developments in the job level and domain of highly-skilled workers', in: H. Heijke, L. Borghans (eds), Towards a transparent Labour Market for Educational Decisions, Ashgate, Aldershot/Brookfield USA/Singapore/Sydney, pp. 2I-56.

F. Cörvers and H. Heijke (2004), Forecasting the labour market by occupation and education: Some key issues, ROA-W-2004/4, Universiteit Maastricht.

\section{Vervangingsvraag}

De vraag naar nieuwe arbeidskrachten die ontstaat doordat de arbeidsplaatsen van werkenden die met pensioen gaan, arbeidsongeschikt worden of zich (tijdelijk) terugtrekken van de arbeidsmarkt opnieuw moeten worden opgevuld. De vervangingsvraag per beroepsgroep kan bovendien ontstaan door de beroepsmobiliteit. De vervangingsvraag naar opleidingstype kan bovendien ontstaan wanneer arbeidskrachten door middel van niveauverhogende of richtingveranderende scholing aanvullende kwalificaties weten te verwerven. Vertrek van werkenden dat niet leidt tot vraag naar nieuwkomers uit hetzelfde opleidingstype of dezelfde beroepsgroep wordt niet meegerekend als vervangingsvraag.

\section{Publicaties:}

E.J.T.A. Willems and A. de Grip (1993), 'Forecasting Replacement Demand by Occupation and Education', International Journal of Forecasting, Vol. 9, pp. 173-I85. E. Willems (1999), Modelling Replacement Demand: A Random Coefficient Approach, ROA-RM-I999/2E, Universiteit Maastricht. 
F. Cörvers, B. Kriechel en R. Montizaan (2006), Scenario-analyse van de vervangingsvraag tot 20I0, ROA-W-2006/I, Universiteit Maastricht.

R. Montizaan (2009), Evaluatie vervangingsvraagprognoses naar opleiding en beroep, ROA-TR-2009/I, Universiteit Maastricht.

\section{Werkloosheid}

Werkloosheid wordt gedefinieerd op basis van de CBS-definitie (www.cbs.nl) van de werkloze beroepsbevolking. Tot de werkloze beroepsbevolking worden gerekend de personen die niet of minder dan 12 uur werken en die:

- werk hebben aanvaard waardoor ze tenminste I2 uur per week gaan werken, of;

- verklaren tenminste I2 uur per week te willen werken, daarvoor beschikbaar zijn en activiteiten ontplooien om werk voor tenminste I2 uur per week te vinden.

Het werkloosheidspercentage wordt bepaald door het aantal werklozen te relateren aan de beroepsbevolking. Kortdurig werklozen worden gedefinieerd als personen die minder dan een jaar werkloos zijn. 


\section{Bijlage B}

\section{Classificaties naar sector, beroep en opleiding ${ }^{106}$}

\section{Bedrijfssectoren}

Landbouw en visserij

Landbouw en visserij

Voeding

Vlees- en visverwerking

Overige voedingsproducten

Drank en tabaksproducten

Chemie

Basischemie

Eindproducten chemie

Kunststofverwerking

Metaal en elektrotechniek

Basismetaal

Metaalproducten

Machine-industrie

Elektrotechniek

Transportmiddelen

Overige industrie

Textiel

Hout- en bouwmaterialen

Papier

Grafische industrie

Energie

Energie

Io6. In het arbeidsmarktinformatiesysteem (AIS) van het ROA zijn de koppelingen met de CBS-classificaties (SBI, SBC, SOI) opgenomen. 
Bouw

Bouw

Exploitatie van onroerend goed

Exploitatie van onroerend goed

Handel en reparatie

Handel en reparatie

Transport

Scheep- en luchtvaart

Weg-en railvervoer

Communicatie

Communicatie

Bank-en verzekeringswezen

Bankwezen

Verzekeringswezen

Horeca en zakelijke dienstverlening

Horeca

Zakelijke dienstverlening

Overige commerciële dienstverlening

Cultuur en speur- en ontwikkelingswerk

Gezondheidszorg

Gezondheidszorg

Overheid en onderwijs

Onderwijs

Overheid

\section{Beroepsklassen en onderliggende beroepsgroepen}

Pedagogische beroepen

Leraar basisonderwijs

Docenten exacte, medische en verzorgende vakken ( $2^{\mathrm{e}}$ graads)

Docenten exacte, medische en verzorgende vakken ( $\mathrm{r}^{\mathrm{e}}$ graads en WO)

Docenten landbouw en techniek ( $2^{\mathrm{e}}$ graads)

Docenten landbouw en techniek ( $\mathrm{r}^{\mathrm{e}}$ graads en WO)

Docenten economisch-administratieve vakken ( $2^{\mathrm{e}}$ graads)

Docenten economisch-administratieve vakken ( $\mathrm{r}^{\mathrm{e}}$ graads en WO) 
Docenten talen en expressie

Docenten letteren ( $\mathrm{I}^{\mathrm{e}}$ graads en WO)

Docenten sociale vakken ( ${ }^{\mathrm{e}}$ graads)

Docenten sociale vakken ( $\mathrm{I}^{\mathrm{e}}$ graads en WO)

Docenten $2^{\mathrm{e}}$ graads zonder specialisatie

Docenten $\mathrm{I}^{\mathrm{e}}$ graads zonder specialisatie

Onderwijskundig medewerkers

Onderwijskundigen en pedagogen

Rij-instructeurs

Zweminstructeurs

Sportinstructeurs

Creatieve beroepen

Tolken, vertalers en schrijvers

Bibliotheekassistenten

Bibliothecarissen

Grafisch ontwerpers

Kunstenaars

Geestelijk verzorgers

Geestelijken

Journalisten

Taalkundigen

Agrarische beroepen

Agrarische hulparbeiders

Agrarische arbeiders

Agrarische vakkrachten

Milieuhygiënisten en agrarisch vertegenwoordigers

Landbouwkundigen

Landbouwmachinebestuurders en vissers

Agrarische bedrijfshoofden

\section{Technische en industrieberoepen}

Productiemedewerkers

Laboratorium-assistenten

Laboranten

Technisch analisten

Natuurwetenschappers

Conciërges

Hoofden technische dienst

Werktuigbouwkundigen

Bouwvakkers

Aannemers en installateurs

Architecten en bouwkundig projectleiders 
Weg- en waterbouwkundigen (academisch)

Weg- en waterbouwkundige arbeiders

Weg- en waterbouwkundige vakkrachten

Weg- en waterbouwkundig ontwerpers en projectleiders

Metaalarbeiders

Bankwerkers en lassers

Bedrijfshoofden metaalbewerking

Assembleurs

Monteurs

Werktuigbouwkundig ontwerpers en hoofden technische dienst

Elektronicamonteurs

Monteurs en controleurs elektrotechnische producten

Elektromonteurs

Elektrotechnisch ontwerpers en bedrijfshoofden

Elektrotechnici

Grafisch productiepersoneel

Grafische vakkrachten

Mechanisch operators

Procesoperators

Procestechnologen

Materiaalkundigen

Confectie-arbeiders

Schoen- en kleermakers

Transportberoepen

Laders en lossers

Chauffeurs

Schippers en conducteurs

Vliegers, scheepskapiteins en leidinggevenden transport

Stewardessen

Medische en paramedische beroepen

Verpleeghulpen en leerling-verpleegkundigen

Verplegenden en doktersassistenten

Therapeuten en verpleegkundigen

Artsen

Apothekersassistenten en medisch laboranten

Medisch analisten

Apothekers

Afdelingshoofden zorginstelling

Economisch-administratieve beroepen

Kantoorhulpen, inpakkers en colporteurs

Ondersteunende administratieve hulpkrachten 
Bedrijfshoofden

Economen

Productieplanners

Organisatie-adviseurs

Organisatiedeskundigen

Receptionisten en administratieve employés

Boekhouders en secretaresses

Assistent accountants

Accountants

Verzekeringsagenten

Commercieel employés (middelbaar)

Commercieel medewerkers (hoger)

Technisch-commercieel employés (hoger)

Technisch-bedrijfskundig medewerkers (middelbaar)

Juridisch en fiscaal medewerkers

Juridisch, bestuurlijk medewerkers

Juristen

Administratieve transportemployés

Leidinggevenden (hoger)

Managers (academisch)

Medisch secretaresses

Informaticaberoepen

Programmeurs

Systeemanalisten

Informatici

Technisch systeemanalisten

Sociaal-culturele beroepen

Activiteitenbegeleiders en medewerkers arbeidsbemiddeling

Medewerkers sociaal-cultureel werk en personeel en arbeid

Hoofden sociaal-cultureel werk en personeel en arbeid

Sociaal-wetenschappelijk medewerkers

Sociaal-wetenschappelijk onderzoekers

Verzorgende en dienstverlenende beroepen

Vakkenvullers

Interieurverzorgers

Verkopers

Winkeliers

Hulpkrachten horeca en verzorging

Ziekenverzorgenden

Verzorgend personeel

Café- en snackbarhouders 
Bedrijfshoofden horeca

Bakkers en slagers

Openbare orde-en veiligheidsberoepen

Aspirant politieagenten, soldaten en beveiligingshulpkrachten

Politieagenten, onderofficieren en beveiligingsemployés

Politie-inspecteurs en officieren

Brandweerlieden

\section{Opleidingscategorieën en onderliggende opleidingstypen}

Basisonderwijs

Basisonderwijs

$V M B O$ tl

$\mathrm{VMBO} \mathrm{tl}$

$V M B O$ groen

VMBO landbouw en natuurlijke omgeving

\section{VMBO techniek}

VMBO bouw

VMBO installatietechniek

VMBO metaal

$\mathrm{VMBO}$ voertuigentechniek

VMBO elektrotechniek

VMBO grafische techniek

VMBO brood en banket

VMBO transport en logistiek

VMBO economie

VMBO administratie, handel en mode

VMBO consumptief en levensmiddelentechniek

VMBO beveiliging

$V M B O$ verzorging

VMBO (uiterlijke) verzorging

HAVO/VWO

HAVO/VWO

$M B O$ groen

$\mathrm{MBO}$ voeding, natuur en milieu 
$\mathrm{MBO}$ groene ruimte

MBO techniek

MBO laboratorium

MBO bouw

$\mathrm{MBO}$ grond-, weg- en waterbouw

MBO installatietechniek

$\mathrm{MBO}$ werktuigbouw en mechanische techniek

MBO fijnmechanische techniek

$\mathrm{MBO}$ motorvoertuigentechniek en tweewielers

$\mathrm{MBO}$ vliegtuigtechniek

$\mathrm{MBO}$ operationele techniek

$\mathrm{MBO}$ elektrotechniek

MBO grafische techniek

$\mathrm{MBO}$ procestechniek

MBO brood en banket

MBO levensmiddelentechniek/vleesverwerking

$\mathrm{MBO}$ vervoer

$M B O$ economie

$\mathrm{MBO}$ administratie en logistiek

MBO handel

$\mathrm{MBO}$ secretariaat

$\mathrm{MBO}$ toerisme en recreatie

$\mathrm{MBO}$ facilitaire dienstverlening

MBO ICT

$\mathrm{MBO}$ geld, bank en belastingen

$\mathrm{MBO}$ verzekeringswezen

$\mathrm{MBO}$ openbare orde en veiligheid

$M B O$ gezondheidszorg

MBO dokters-, tandarts- en dierenartsassistent

$\mathrm{MBO}$ apothekersassistent

$\mathrm{MBO}$ verpleging

$\mathrm{MBO}$ gezondheidstechniek

$\mathrm{MBO}$ beweging en therapie

$M B O$ sociaal-cultureel

MBO sociaal-pedagogisch en welzijn

$\mathrm{MBO}$ verzorging

$\mathrm{MBO}$ uiterlijke verzorging

$\mathrm{MBO}$ horeca 
HBO groen

$\mathrm{HBO}$ landbouw en veeteelt

HBO milieukunde

HBO techniek

HBO laboratorium

HBO bouwkunde

HBO civiele techniek

$\mathrm{HBO}$ werktuigbouwkunde

HBO elektrotechniek

$\mathrm{HBO}$ informatica

$\mathrm{HBO}$ chemische technologie

$\mathrm{HBO}$ vervoer en logistiek

HBO economie

$\mathrm{HBO}$ accountancy en bedrijfseconomie

HBO commerciële economie

$\mathrm{HBO}$ toerisme en recreatie

$\mathrm{HBO}$ recht en bestuur

$\mathrm{HBO}$ secretariaat

$\mathrm{HBO}$ bedrijfskunde

$\mathrm{HBO}$ openbare orde en veiligheid

$H B O$ onderwijs

HBO lerarenopleiding basisonderwijs

HBO lerarenopleiding talen

HBO lerarenopleiding natuur en techniek

HBO lerarenopleiding economie en maatschappij

HBO lerarenopleiding lichamelijke opvoeding

$\mathrm{HBO}$ lerarenopleiding medisch en verzorging

$\mathrm{HBO}$ lerarenopleiding expressie

HBO sociaal-cultureel

$\mathrm{HBO}$ tolk en vertaler

$\mathrm{HBO}$ communicatie en journalistiek

$\mathrm{HBO}$ maatschappelijk werk en hulpverlening

$\mathrm{HBO}$ personeel en arbeid

$\mathrm{HBO}$ documentatie en informatie

$\mathrm{HBO}$ pedagogie

HBO horeca

$\mathrm{HBO}$ uitvoerende en beeldende kunsten 
HBO paramedisch

$\mathrm{HBO}$ verpleegkunde

HBO (fysio)therapie

$\mathrm{HBO}$ voeding

$\mathrm{HBO}$ radiologie

WO groen

WO landbouw en milieukunde

WO techniek

WO wiskunde en natuurwetenschappen

WO bouwkunde

WO civiele techniek

WO werktuigbouwkunde

WO elektrotechniek

WO informatica en bestuurlijke informatiekunde

WO economie en recht

WO economie

WO bedrijfskunde

WO accountancy en belastingen

WO rechten en bestuurskunde

WO letteren en sociaal-cultureel

WO letteren

WO theologie

WO sociale wetenschappen

WO kunstwetenschappen

WO medisch

WO (dier)geneeskunde

WO tandheelkunde

WO farmacie en medische biologie 



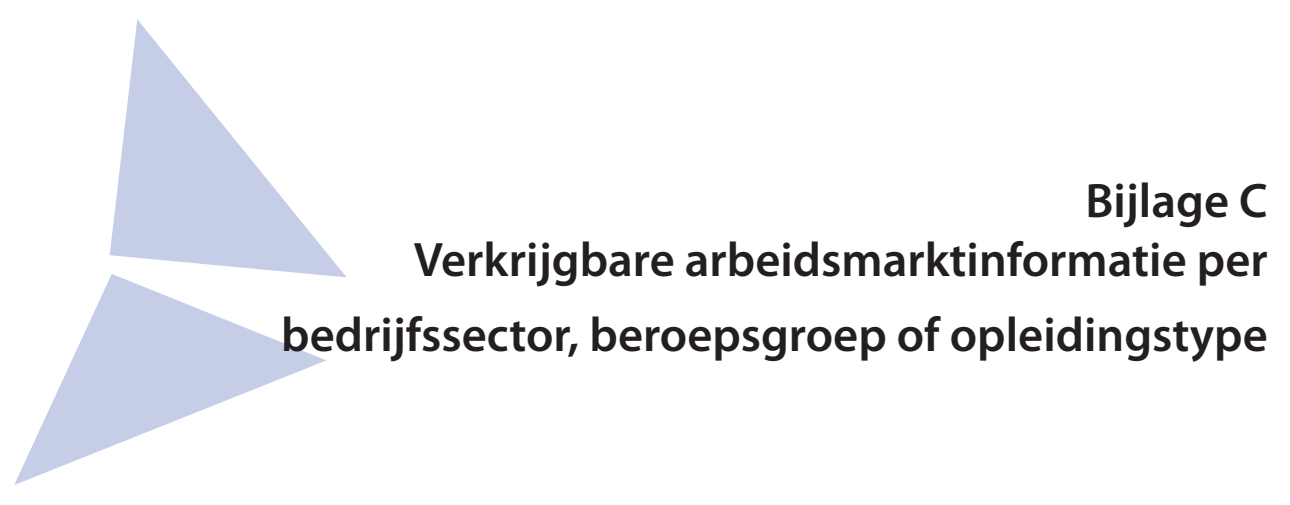

Per bedrijfssector, beroepsgroep of opleidingstype (zie Bijlage B) zijn de hieronder weergegeven variabelen verkrijgbaar. De betreffende arbeidsmarktinformatie is afkomstig uit het Arbeidsmarktinformatiesysteem (AIS) van het ROA.

Bedrijfsectoren

- aantal werkenden

- percentage vrouwen

- percentage allochtonen

- percentage jongeren ( $15-29$ jaar) en ouderen (50-64 jaar)

- percentage werkenden naar opleidingsniveau

- percentage deeltijdarbeid

- percentage flexibel en vast werk van arbeidskrachten in loondienst

- percentage werkenden in het midden- en kleinbedrijf

- percentage zelfstandigen

- percentage werkenden dat deelneemt aan scholingstrajecten korter dan zes maanden

- percentage werkenden dat deelneemt aan scholingstrajecten van zes maanden of langer

- gemiddeld bruto uurloon van werknemers

- percentage werkzaam in stank, lawaai, tocht of hoge/lage temperaturen

- percentage werkzaam met gevaarlijke stoffen

- percentage werkzaam onder gevaarlijke omstandigheden

- percentage werkzaam in lichamelijk zwaar werk

- percentage werkzaam in geestelijk zwaar werk

- percentage werkzaam in emotioneel zwaar werk

- percentage werkzaam met agressie op de werkplek

- percentage werkzaam aan lopende band

- percentage werkzaam met herhaling van dezelfde eenvoudige werkzaamheden

- percentage werkzaam met mensen (patiënten, cliënten, leerlingen enz.)

- percentage werkzaam met werk buiten zijn/haar vak of beroep

- percentage werkzaam in werk met zelf begintijd of eindtijd bepalen

- percentage werkzaam met werk in ploegendienst of wisselende diensten 
- percentage werkzaam in werk met onregelmatige werktijden (door werkgever bepaald)

- percentage werkzaam met werk op zondag

- percentage werkzaam met werk op zaterdag

- percentage werkzaam met werk in nachtdienst

- percentage vacatures op enquêtemoment

- percentage bedrijven met vacatures

- percentage bedrijven met vacatures langer dan 3 maanden openstaand

- percentage bedrijven met vacatures die moeilijk vervulbaar zijn

- belangrijkste beroepsgroepen

- belangrijkste opleidingstypen

- conjunctuurgevoeligheid van de werkgelegenheid

- verwachte uitbreidingsvraag

- verwachte knelpunten op middellange termijn in de personeelsvoorziening

\section{Beroepsgroepen}

- aantal werkenden

- percentage vrouwen

- percentage allochtonen

- percentage jongeren (I5-29 jaar) en ouderen (50-64 jaar)

- gemiddelde leeftijd

- percentage werkenden naar opleidingsniveau

- percentage deeltijdarbeid

- percentage flexibel en vast werk van arbeidskrachten in loondienst

- percentage werkenden in het midden- en kleinbedrijf

- percentage zelfstandigen

- percentage werkenden dat deelneemt aan scholingstrajecten korter dan zes maanden

- percentage werkenden dat deelneemt aan scholingstrajecten van zes maanden of langer

- gemiddeld bruto uurloon van werknemers

- belangrijkste bedrijfssectoren

- uitwijkmogelijkheden naar verschillende bedrijfssectoren

- belangrijkste opleidingstype

- substitutiemogelijkheden tussen mensen met uiteenlopende

- opleidingsachtergronden

- conjunctuurgevoeligheid van de werkgelegenheid

- verwachte uitbreidingsvraag

- verwachte vervangingsvraag

- verwachte baanopeningen

- indicator toekomstige knelpunten in de personeelsvoorziening naar beroep (ITKB) 


\section{Opleidingstypen}

- aantal werkenden

- arbeidsmarktpositie potentiële beroepsbevolking

- participatie schoolverlaters in vervolgopleidingen

- percentage schoolverlaters met een intredewerkloosheid van 4 maanden of langer

- percentage werkloze schoolverlaters

- percentage vrouwen onder werkenden

- percentage allochtonen onder werkenden

- percentage allochtonen onder schoolverlaters

- percentage jongeren ( $55-29$ jaar) en ouderen (50-64 jaar) onder werkenden

- gemiddelde leeftijd onder werkenden

- gemiddelde leeftijd onder schoolverlaters

- percentage deeltijdarbeid onder werkenden

- percentage deeltijdarbeid onder werkzame schoolverlaters

- percentage flexibel en vast werk van arbeidskrachten in loondienst

- percentage werkzame schoolverlaters met een vast dienstverband

- percentage werkenden in het midden- en kleinbedrijf

- percentage werkzame schoolverlaters in het midden- en kleinbedrijf

- percentage zelfstandigen onder werkenden

- percentage werkenden dat deelneemt aan scholingstrajecten korter dan zes maanden

- percentage werkenden dat deelneemt aan scholingstrajecten van zes maanden of langer

- gemiddeld bruto uurloon van werknemers

- gemiddeld bruto maandloon van werkzame schoolverlaters

- percentage werkzame schoolverlaters met een functie in de eigen vakrichting

- percentage werkzame schoolverlaters van wie kwalificaties onderbenut worden

- aantal leerlingen en kenmerken naar geslacht en leerweg (BBL/BOL)

- aantal gediplomeerden en kenmerken naar geslacht en leerweg (BBL/BOL)

- belangrijkste beroepsgroepen

- uitwijkmogelijkheden naar verschillende beroepsgroepen

- belangrijkste bedrijfssectoren

- uitwijkmogelijkheden naar verschillende bedrijfssectoren

- overzicht opleidingstypen waarvan op de arbeidsmarkt sterke concurrentie wordt ondervonden

- conjunctuurgevoeligheid van de werkgelegenheid

- verwachte uitbreidingsvraag

- verwachte vervangingsvraag

- verwachte baanopeningen

- verwachte instroom van schoolverlaters

- indicator toekomstige arbeidsmarktperspectieven naar opleiding (ITA)

- indicator toekomstige knelpunten in de personeelsvoorziening naar opleiding (ITKP) 
